\title{
The Politics of Land (and) Violence in Ghana
}

\author{
Nicole Renee Lefore \\ Milton-Freewater, Oregon
}

B. A. International Studies, Whitworth College, 1991

MSc. Development Studies, School of Oriental and African Studies, University of

London, 1996

A Dissertation Presented to the Graduate Faculty of the University of Virginia in Candidacy for the Degree of Doctor of Philosophy

Department of Politics

University of Virginia

December 2012

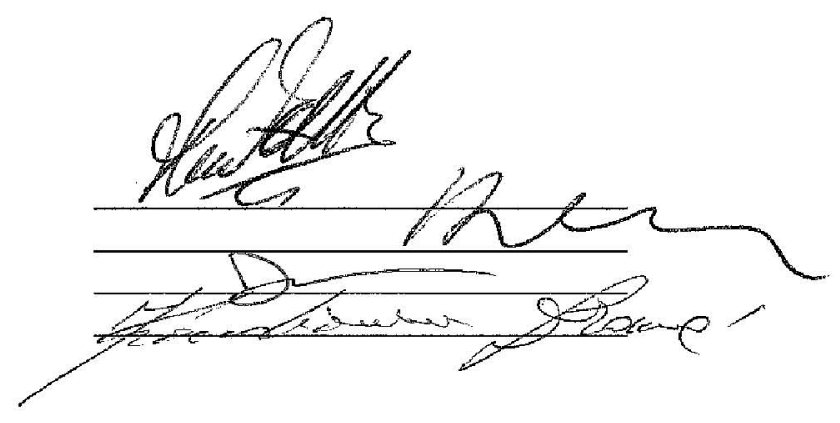




\title{
The Politics of Land (and) Violence in Ghana
}

\author{
Nicole Renee Lefore
}

\begin{abstract}
$\underline{\text { Abstract }}$
Conflict over land has increased and the nature of land-related violence has changed in Ghana, as well as in other countries in Africa, undermining economic growth and threatening political stability. Violence over land had once been primarily between customary groups over boundaries, or between peasants and the state over expropriation of customary land by those in power. Now, violence has become more destructive and deadly, and is most often between factions within the ruling class who have no customary claim to the land under dispute. This research seeks to explain how relations in land have changed and what caused the related change in the nature of land violence. It uses class analysis to examine differences in land relations across regimes since the 1970s to the early 2000s. The study finds that the nature and levels of violence changed alongside the instrumental role of land in ruling class strategies for gaining power and accumulating wealth. In the 1970s, the military regime used land for accumulation and patronage. Peasants engaged in sporadic violence to resist the loss of land, while the ruling class deployed state coercion to suppress resistance. The authoritarian regime that took over state power in 1981 sought the support of subaltern classes. Violence over land changed, with the regime using state coercive bodies to repress rivals and defend subaltern interests in land. Following democratization in 1992, land became instrumental in the intra-ruling class factional contest for state power to build patron-client networks, provide revenue for
\end{abstract}


electoral politics, and enable primitive accumulation. Violence occurred when disputants from rival ruling class factions without customary rights to the land deployed private coercive means to acquire and defend land. The dissertation concludes that factional conflict within an inchoate ruling class was a primary underlying cause of land violence and the changes in the nature of violence over land in Ghana. The study offers lessons for future development planning in land institutions and governance. 


\section{Table of Contents}

Acknowledgements vii

$\begin{array}{ll}\text { Acronyms } & \text { Ix }\end{array}$

Chapter 1. The Emerging Trend of Violence in Changing Land Relations 1

Section 1. Shifting the Focus to Land Violence 3

Section 2. Addressing the Land Violence Question 6

Section 3. Presenting the Case: Method and Evidence 10

Section 4. Current Approaches to Land Violence 13

Section 5. An Introduction to Changing Land Relations and Political Power 16

Section 6. A Preliminary Look at the Ghana Case 23

Conclusion. The Structure of the Dissertation 27

Chapter 2. Competing Explanations for Land Violence 28

Section 1. Rational Choice Theories and Land 29

Section 2. An Alternative Paradigm: Negotiability, Contingency and Cultural

$\begin{array}{ll}\text { Durability } & 41\end{array}$

Section 3. Patterns of Violence: Structural Arguments and Class Differentiation 50

Section 4. Land Violence: A Class Argument 58

$\begin{array}{ll}\text { Conclusion } & 73\end{array}$ 
Chapter 3: The foundations of a conflictual land market: Ghana under the $\begin{array}{ll}\text { NRC/SMC } & 75\end{array}$

Section 1. Means to Access and Maintain Power: The Political Strategy 77

Section 2. Means of Accumulation: Global Market Shocks and Shifting Strategies 86

Section 3. State Coercion and Dominance of a Ruling Class Faction 98

Section 4. Forging a Violent Land Market: Resistance to Primitive Accumulation

$\begin{array}{ll}\text { in Land } & 103\end{array}$

Section 5. The Mounting Opposition and the End of the Generals 109

$\begin{array}{ll}\text { Conclusion } & 117\end{array}$

Chapter 4. New Political Strategies and a Counter-movement in Land

Relations: The PNDC Years $\quad 119$

Section 1. Means to Access and Maintain Power: Fusing the Political and

Coercive Strategies

Section 2. Means of Accumulation: Tackling Domestic Political Challenges and

Defending Structural Adjustment

Section 3. Land Relations during the PNDC: A Countermovement (and Back

Again)

Section 4. Slippage in the Countermovement: The Transition to elected District

Assemblies

172

Conclusion

176 
Chapter 5: Electoral Patronage, Privatized Coercion, and Land Violence:

$\begin{array}{lr}\text { Ghana under democracy } & 180\end{array}$

Section 1. Means to Access and Maintain Power: Electoral Politics 182

Section 2. Means of Accumulation: Election Financing, Patronage and the Market 203

Section 3. State Coercion and the Democratic Transition: Instruments of 215

Institutional Weakness

Section 4. Land Relations and Democratization: the Emergence of a Violent Land

$\begin{array}{ll}\text { Sales Market } & 230\end{array}$

Conclusion: The Central Questions of the Dissertation 241

Chapter 6. Answers to the questions on Ghana's land violence 245

Section 1. Review of the Case and Comparative Analysis 245

Section 2. Causes of Land Violence in Ghana: Answers from Case Analysis 254

Section 3. An Alternative Argument for Land Violence 267

Section 4. A Limited Explanation and the Need for Further Study 273

Section 5. Recommendations for Development-oriented Policy and Planning 277

Conclusion: Consequences of the Emergence of the Land Market 283

$\begin{array}{ll}\text { Bibliography } & 285\end{array}$ 


\section{$\underline{\text { Acknowledgements }}$}

Much of Ghanâ̂s history of land is either undocumented or captured in documents that are not accessible or are held by private individuals. The sensitive nature of the topic of land ownership contributes to the difficulty in obtaining information on land. And much of the knowledge on the history of the politics of land remains only in the oral histories. This dissertation would not have been possible without the assistance of numerous people willing to share their knowledge and documents, including the following: staff of the National Archives of the Ghana Public Records Office, who assisted with finding documents under challenging conditions; former cadres P. K. Abonie, Kwao Sackey and Africanus, among others; customary leaders and youth associations, particularly those from James Town, Weija and La, with special thanks to Nii Sackey; former officials of the National Investigations Committee; officials of the Ghana Police Service, Bureau of National Investigations and National Security; K. B. Asante for explaining the politics of land relations between customary holders and government prior to independence and under the CPP; former Accra Mayor, Nat NunoAmarteifio; former officials of the PNDC; researchers at the Kofi Annan Peace Keeping Institute in Accra; and former and current Members of Parliament.

This dissertation is dedicated to Naa Archarwa Barnor. 
The love of property and consciousness of right and wrong have conflicting places in our organization, which often makes a man's course seem crooked, his conduct a riddle.

Abraham Lincoln 


\section{Acronyms}

ACDR: Association of the Committees for the Defence of the Revolution

AFCDR: Armed Forces Committees for the Defense of the Revolution

AFRC: Armed Forces Revolutionary Council

BNI: Bureau of National Investigations

CDO: Citizens Defence Organization

CDR: Committee for the Defence of the Revolution

CPP: Convention Peopleô Party

CVC: Citizens Vetting Committee

GBC: Ghana Broadcasting Corporation

GNA: Ghana News Agency

IMF: International Monetary Fund

NDC: National Democratic Congress

NIC: National Investigations Committee

NPP: National Patriotic Party

NRC: National Redemption Council

PDC: Peopleô Defence Committee

PNDC: Provisional National Defence Council

PP: Progress Party

SFO: Serious Fraud Office

SMC: Supreme Military Council

WDC: Workers Defence Committee 


\section{Chapter 1. The Emerging Trend of Violence in Changing Land}

\section{Relations}

In December 1998, in the village of Ablekuma, near Accra, Ghana, a local dispute over land turned violent, attracting national attention. A number of policemen had acquired land in a disputed land deal. Land speculators often gave plots of land to police as a means to protect their acquisitions. In this case however, that protection had turned to conflict. A series of violent clashes had already taken place between the policemen and armed guards hired by the opposing claimants. On a December day, two policemen went to the village armed and prepared to fight. Their opponent's guards met them with force to drive them away. The situation spun out of control. Local newspapers reported the bloody event in detail. “. . . the policemen refused to comply [with demands of armed guards] ... deflated the tyres of the [police] vehicle and dragged the two [police]men out . . and pounced on them with sticks and pieces of blocks and hit them several times with the butt of an AK 47 rifle... . The two peace officers tried in vain to explain their mission to the mob, but it did not listen, and at one stage, shot the policeman Jerry ["Taller"] from the back, leading to his instant death. [The other policeman] Kweku Ninja, on realising that his colleague had been murdered, took to his heels, but due to the injuries he sustained on his head, he could not get far. He was chased with a white car [of land guards]. . . knocked down, dragged to the village and shot. . . the mob then dragged the dead men into the bush, and returned later soaked in blood and mud to inform the people that 'they had finished them' and that no one will ever find their bodies. The villagers . . were warned [by the land guards] that anyone who dared talk to a stranger about the incident would be killed in the same 
manner...."l Colleagues of the policemen, also embroiled in the dispute, went to Ablekuma to look for 'Ninja' and 'Taller', but the villagers refused to talk to them or lead them to the bodies. The police retaliated and set the thatch roofed village on fire, leaving dozens homeless. The public followed the media reports and became outraged. Parliament debated the 'problem' of land guards and land disputes that they acknowledged threatened the peace. President Rawlings visited Ablekuma and met with the disputants and villagers. His involvement led to the discovery of missing bodies of land guards. The involvement of high-level politicians also fuelled speculation that officials had their own stakes in the land under dispute.

What caused violence over land in Ghana? Why was there a violent struggle for land in the country after its lauded democratic transition in the early 1990s? The increased intensity of land-related violence in Ghana seemed shocking primarily because the nature of land conflict in Ghana had changed. As in other African countries, customary ethnic groups historically engaged in a struggle against each other over boundaries or against ñalienò migrants who sought access to land for farming. In the 1970s, peasants had sporadically used violent means to resist expropriation of land by members of the ruling class, which was then suppressed by violence from the state coercive institutions. However, by the late 1990s, fewer disputes involved disputes over boundaries by those with customary rights to the land. The worst disputes occurred between individuals of the ruling class, who had no customary ties to the land under dispute. Moreover, the new trend in land violence now involved the destruction of

\footnotetext{
${ }^{1}$ Mary Mensah, "Police Operation at Ablekuma Uncovers the Truth: 2 Cops Killed, over 100 People Arrested in Swoop," Daily Graphic, December 4, 1998, 1.
} 
buildings and property, contract killings, and pockets of private armed struggle over the possession of land. Additionally, disputants from the ruling class commonly retained ñland guardsò from among the subaltern classes. They paid large sums of cash and often alcohol and illegal drugs, alongside the opportunity for plunder. In a short time, the land guards had developed small, private armies with para-military training, sophisticated communications and weapons, and hierarchical structures. The public concern over the threat land disputes posed to security turned to outrage with the violent events in Ablekuma in December 1998. Why had the state failed to respond to this growing crisis over land?

\section{Section 1. Shifting the Focus to Land Violence}

Most current scholarly attention is on the ñscramble for landò or the ñglobal land grabò in recognition of a trend in large-scale land acquisition by agri-business and real estate development that marginalizes the poor. Other case studies seek to understand the impact of land titling programs on small or peasant farmers, which are being promoted through development aid. Studies often treat violence as tangential to this process of expropriation or titling. Yet, land clashes occur commonly across many African countries, such as South Africa, Burundi, ${ }^{2}$ Uganda $^{3}$ and Kenya ${ }^{4}$. Contemporary land-

\footnotetext{
${ }^{2}$ Prunier, G., The Rwanda Crisis 1959-1994: History of a Genocide (London: Hurst and Co., 1995).; Catherine Andre and Jean-Phillipe Platteau, "Land Relations under Unbearable Stress: Rwanda Caught in the Malthusian Trap," Journal of Economic Behavior and Organization 34 (1998).; A. Kairaba, ñCountry Case Study: Rwandaò World Bank Regional Workshop on Land Issues in Africa and the Middle East, Kampala, Uganda, April 29-May 2, 2002.

${ }^{3}$ K. Deininger and R. Castagnini, "Incidence and Impact of Land Conflict in Uganda," Policy Research Working Paper (World Bank, 2004).
} 
related violence is not limited to Africa, as well. Haiti ${ }^{5}$ in the Caribbean and Mexico, ${ }^{6}$

Colombia, ${ }^{7}$ Brazil $^{8}{ }^{8}$ El Salvador and Guatemala ${ }^{9}$ in Latin America $^{10}$ all suffer from

ongoing disputes over land. The rise in land-related violence across impoverished

countries and regions suggests an emerging, and dangerous, trend.

Scholars address land violence more explicitly in research on civil war. Indeed,

existing research on civil war highlights the fact that seemingly limited disputes hold the

potential to explode into larger conflicts. ${ }^{11}$ Scholars and development agencies identified

the common factor of tension over land in the conflicts in Rwanda, Zimbabwe, ${ }^{12}$ Liberia,

Sierra Leone and Cote dâvoire. Unresolved land disputes that persist in post-conflict

countries $і$ Sierra Leone, Liberia and Cote dôIvoire and Zimbabwe, ${ }^{13}$ among others $і ̈$

continue to threaten the peace process. A development consultant to the Truth and

${ }^{4}$ Karuti Kanyinga, "Re-Distribution from Above: The Politics of Land Rights and Squatting in Coastal Kenya," (Nordiska Afrikainstitutet, 2000); C. R. J Southgate, and D.Hulme, "Competition, Cooperation and Conflict: The Dynamics of Resource Management in Loitokitok, Kenya," in African Enclosures? The Social Dynamics of Land and Water, ed. P. Woodhouse, Bernstein, H., Hulme, D. (London: James Currey, 2000).; Jacqueline Klopp, "Pilfering the Public: The Problem of Land Grabbing in Contemporary Kenya," Africa Today 47, no. 1 (2000).

${ }^{5}$ Phillip Howard, "Development-Induced Displacement in Haiti," Refuge 16, no. 3 (1997).

${ }^{6}$ Bobrow-Strain, Intimate Enemies: Landowners, Power and Violence in Chiapas (Duke University Press, 2007).; Andres Villareal, "The Social Ecology of Rural Violence: Land Scarcity, the Organization of Agricultural Production, and the Presence of the State," American Journal of Sociology 110, no. 2 (2004).

7 "Colombia Hacienda Bellacruz: Land, Violence and Paramilitary Power," ed. Amnesty International (Amnesty International, 1997).; Nazih Richani, Systems of Violence: The Political Economy of War and Peace in Colombia (Albany: State University of New York Press, 2002).

${ }^{8}$ John L. Hammond, "Law and Disorder: The Brazilian Landless Farmworkers' Movement," Bulletin of Latin American Research 18, no. 4 (1999).

${ }^{9}$ Megan Ybarra, "Violent Visions of an Ownership Society: The Land Administration Project in Peten, Guatemala," Land Use Policy 26, no. 1 (2009).

${ }^{10}$ Sam Moyo, Yeros, Paris, Reclaiming the Land: The Resurgence of Rural Movements in Africa, Asia and Latin America (London and New York: Zed Books, 2005).; Cristobal Kay, "Reflections on Rural Violence in Latin America," Third World Quarterly 22, no. 5 (2001).

${ }^{11}$ André, "Land Relations under Unbearable Stress: Rwanda Caught in the Malthusian Trap."

${ }^{12}$ A. K. Shutt, ñôEveryone has a right to farmô Generational conflict in the African freehold areas of Zimbabwe, ò International Land Tenure Conference, Orlando, Florida, November 1996.

${ }^{13}$ Bill H. Kinsey, "Zimbabwe's Land Reform Program: Underinvestment in Post-Conflict Transformation," World Development 32, no. 10 (2004). 
Reconciliation Commission, in Liberia, says that theñwhole land issue is one key issue that has to be given serious attention if we are to live in peace and stability..$^{14}$

Studies suggest that land violence threatens state security. The growth of armed militias in the face of land issues can signal the rise of warlords. Youth who are expelled and alienated from traditional lands can feed insurgencies, particularly where the state defends legally questionable and inequitable land expropriation, as in countries across Africa. Land violence also spills over into everyday life with the spread of weapons and the overlap of paramilitary violence with illicit drug use. The threat to personal security and property leaves communities living in fear while violent divisions over land become part of divisive political partisanship. The legitimacy of the police, the state, and political leaders erodes.

Examining land violence is critical not only to understand the potential to escalate, but also because land disputes undermine the economic development of these regions. Studies link low productivity levels of agricultural plots to the potential for, or actual presence of, land conflict. ${ }^{15}$ The lack of secure land also undermines urban housing and development efforts at a time when urban populations are growing rapidly. ${ }^{16}$ The significant financial resources needed to obtain and defend land holdings against plunder and extortion in both agricultural and urban settings lower investment efficacy. Longterm private investment is less likely in the face of land conflict.

\footnotetext{
${ }^{14}$ BBC, Land Disputes Threaten Liberia (2008 [cited 10/14/08); available from http://news.bbc.co.uk/1/hi/world/africa/7669444.stm.

${ }^{15}$ Klaus Deininger and Raffaella Castagnini, "Incidence and Impact of Land Conflict in Uganda," Policy Research Working Paper (World Bank, 2004).

${ }^{16}$ Carole Rakodi, "Residential Property Markets in African Cities," in The Urban Challenge in Africa: Growth and the Management of Its Large Cities, ed. Carole Rakodi (Tokyo, New York, Paris: United Nations University Press, 1997).
} 


\section{Section 2. Addressing the Land Violence Question}

The prevalence of land-related violence suggests a widespread change in social relations over land. The primary question this study seeks to answer is what caused the change in land violence in Ghana? To get at that question, the dissertation asks other key questions. How have land relations changed and why did the nature of violence change with it? Who is benefiting from and who is excluded from this process of change in land? Why does the state fail to stop the growth of violence that poses a political threat?

There is a broad debate on the meaning and definitions of violence, including on violence over land. The wide range of definitions of violence extends from intentional ñarmful actionò to patterns in which human rights are denied. ${ }^{17}$ This study uses the definition for violence as force that threatens peoplesôlives and bodies. ${ }^{18}$ The narrow concept of violence used here excludes the broader, or ñcomprehensive, ò conception that incorporates the violation of rights. ${ }^{19}$ This study purposefully separates the debate over structural or psychological violence from the specific phenomenon of threatening physical harm. This dissertation also notes the distinction between violence and war in its question on the causes of violence over land. This dissertation focuses on social violence, in which disputants deploy physical violence to achieve their interests, but the number of deaths remains below the thresholds of war. ${ }^{20}$ It does not seek to analyze wars over land

\footnotetext{
${ }^{17}$ Ted R. Gurr and Vaughn F.Bishop, "Violent Nations, and Others," Journal of Conflict Resolution 20, no. 1 (1976).

${ }^{18}$ Edna G. Bay, "Introduction," in States of Violence: Politics, Youth and Memory in Contemporary Africa, ed. Edna G. Bay and Donald L. Donham (Charlottesville and London: University of Virginia Press, 2006). ${ }^{19}$ J. J. Degenaar, "Concepts of Violence," Politikon 7, no. 1 (1980).

${ }^{20}$ By definition, groups of people engage violently in disputes over land, but this is not war where the number of annual deaths falls below the 1,000 threshold. In addition, disputants are not rebels or government troops with publicly identifiable leadership or stated goals embroiled in sustained violence. For
} 
or suggest that the conclusions apply to cases of war. In short, the purpose of this study is to explain changes in the use of excessive or destructive force over land in Ghana.

This dissertation seeks to strengthen the analysis provided by the prevailing studies on land tenure and causes of land-based violence, which are summarized below. This dissertation uses a class analysis to understand the causes of violence over land and how land violence changed over the period of study. Many studies focus on the role of institutions in land relations, but a class analysis is critical to deepen this understanding. The ruling class creates institutions, including property rights institutions. As North argued, property rights reflect the interests of the ruling class. ${ }^{21}$ The ruling class creates and controls the institutions that largely determine the right to allocate, use, and own land and property, according to its own interests. In addition, land has been used historically as a means to organize social and class relations in Ghana. Access to and control over allocation of land has historically determined the relative power of classes.

In Ghana, the ruling class is identified by access to the institutions that determine access to resources. These include institutions that set policy, allocate and disburse resources, and provide access to contracts, finances and credit. The ruling class does not own the primary means of production, but controls the institutions that enable it to accumulate. At times, the state institutions of coercion are mobilized to control the institutions of state power and to enable accumulation. The ruling class includes the

a discussion of categories of conflict, see: Christopher Cramer, "Categories, Trends and Evidence of Violent Conflict," in Violence in Developing Countries (Bloomington and Indianapolis: Indiana University Press, 2006).; Phillipe Le Billon, "The Political Ecology of War: Natural Resources and Armed Conflict," Political Geography 20 (2001).

${ }^{21}$ Douglass C. North, Structure and Change in Economic History (New York: W. W. Norton, 1981). 
traditional aristocracy, which historically has controlled access to and allocation of natural resources, and continues to do so under the constitution.

Given the link between class relations and land, the nature of Ghanaôs ruling class is critical to understanding land-related violence. In Ghana, the ruling class is fragmented and the primary motive of each ruling class faction is to become dominant. Each faction seeks to eliminate the opposing ruling class factions to consolidate its power. This intraruling class struggle largely defines how the ruling class relates to the traditional aristocracy and subaltern classes. The ruling class factions use land as an instrument to order relations with the other classes. Political strategies change with the domestic and global context, and this shapes the political value and instrumentality of land.

Ghanaôs ruling class is divided into two main factions that can be identified by political traditions that formed opposing sides during the struggle for independence: Nkrumahist and Danquah-Busian. The Nkrumahist faction historically tended toward policies that sought a broader distribution of wealth and the creation of state institutions that could take over some of the local roles of the traditional aristocracy. The PNDC incorporated many Nkrumahists and technocrats trained at the Nkrumah Ideological Institute into its leadership and picked up substantial support from the Nkrumahist base of workers and teachers. The Danquah-Busian political tradition emphasized free-market policies and boasted the support of prominent business personalities, but, at the same time, supported the involvement of chiefs in national and local politics and resource management. The two factions have historically sought exclusive control over power and natural resources. 
Violence, Edna Bay suggests, reflects historical shifts in political power. ${ }^{22}$ Changes in the means to access power and the primary means to accumulate constitute such a shift. Therefore, the dissertation uses three primary areas of analysis: the means to access power, the primary means of accumulation and the use of coercion to gain power and accumulate. It analyzes land relations through these three areas, and compares violence across political periods. It primarily addresses the changing nature of land violence, while also noting the frequency of land violence.

The periods under comparison here are noted by regime change and change between governments. The first period begins with the military authoritarian regime in the 1970s under Acheampongô National Redemption Council (NRC). The second period starts in the 1980s with the authoritarian, quasi-military Provisional National Defense Council (PNDC). The study continues into a third period with the democratic phase that followed the ñfoundingòelection of the Fourth Republic in 1992. Rapid change in land relations coincided with democratization and violence intensified even with the benchmark signs of electoral liberalism that marked the 2000 changeover in ruling party. The dissertation compares the period that preceded structural adjustment with the periods that initiated and followed structural adjustment and democratization, because various theoretical approaches view structural adjustment as either a causal factor for land violence, or a potential remedy for land violence where it includes land tenure reform.

\footnotetext{
${ }^{22}$ Bay, Edna G., "Introduction," In States of Violence: Politics, Youth and Memory in Contemporary Africa, edited by Edna G. Bay \& Donald L. Donham. Charlottesville and London: University of Virginia Press, 2006.
} 


\section{Section 3. Presenting the Case: Method and Evidence}

Ghana provides a representative case for a study on persistent land violence. The country adopted stabilization and structural-adjustment policies in the 1980s, as did many other states in Africa and in the developing world. Ghana is seen as a success story by neo-liberal development institutions. This success in implementing structural adjustment programs should provide a solid case to test structural adjustment as a causal factor for either increasing or reducing land violence. Ghanaô structural adjustment experience might also point to ways in which structural adjustment changes land relations, if at all.

In the late 1980s and early 1990s, Ghana also undertook democratization and decentralization like many African countries. The process of regime change alters strategies for political survival and dominance. The change between, and differences across, regime types create changes in the means through which the dominant class obtains legitimacy, buttresses its power, and subdues challenges to that power from rival factions and subaltern classes. The institutional changes associated with the process of democratization provide an area of analysis in understanding changes in land and power relations. The Ghana case is of particular interest because land violence appeared to worsen after democratization, countering expectations that democracy would bring peace.

The Ghana case is also distinctive because the country has not experienced a civil war or a collapsed state, which is unusual for West Africa. Ghana is generally not considered a fragile state. Ghana shares a similar economic and cultural history with other countries in the region and with some fragile states: primary-commodity, exportbased economies, high-value mineral exports in diamonds and gold, ethnic diversity, and 
parallel customary-statutory legal systems. Other studies have examined the causes of civil-war in neighboring countries, and the possible role of land conflict as a trigger in those wars. Studies on land and civil war generally do not compare cases to explain why some land disputes lead to civil war, whereas other land disputes remain contained. This study then could be useful to understand how to prevent land disputes from erupting into broader conflict and war. In this regard, the Ghana case provides a much-needed study for a cross-national comparison of land disputes, conflicts and land-related civil war.

\section{$\underline{\text { Evidence }}$}

This dissertation addresses the rising intensity of violence caused by land disputes and relies on sources that document land disputes and violence. Newspaper reports and official statements from government officials chronicle this increase in violence. Newspapers provide background information and, occasionally, details about the disputing parties. News reports suggest the extent of the violence, the experiences of communities plagued by it, and the types of injuries sustained by individuals in land disputes. State daily newspapers are easily accessed in the Ghana National Archives and in private collections that document the early $20^{\text {th }}$ century to the present, with occasional blackout periods around the times when coups took place. Newspapers not only underestimated the number of violence incidents but were discouraged from reporting them by state officials. Thus, due to the lack of reliable data, a statistical analysis of land related violence is difficult. The state provides estimates on the number of land-dispute cases in the court system, but state officials themselves question these statistics. 
Neither the court records nor police reports contain reliable information on landrelated violence. ${ }^{23}$ However, non-governmental organizations and United Nations agency reports on the numbers and general availability of small arms provide some clues. These bodies have reported increases in the numbers of more sophisticated, and deadly, weapons used in land disputes. They also document an increase in private armies of land guards. Moreover, the University of Ghanaô Centre for Remote Sensing and Geographical Information Systems provides satellite mapping of land-use and growth patterns which reveals an increase in land sales and demand for peri-urban land in particular during this period. Census data is also available throughout the period of this study. Additionally, government agencies provide figures on the numbers of land transactions and the sizes and costs of plots sold over the period. This information provides data on periodic rises in land demand and values; time periods for real-estate development booms in specific geographical areas; land-population densities; and landuse patterns. The data is analysed within global and domestic political and economic trends. In addition, interviews supplemented the primary material. Personal interiews with key social and political actors enhance the understanding of the statistical information given its limitations. ${ }^{24}$

\footnotetext{
${ }^{23}$ Most incidents of violence over land are not reported to or recorded by police. The police usually do not specify land in records when reporting incidents of land violence or threats of violence. In many cases, police do not take statements at all in cases of land violence, arguing that it does not fall within their jurisdiction and as such, they are not responsible.

${ }^{24}$ Interviews were used to verify the validity of data found in reports, and occasionally, to locate reports missing from the National Archives. In Ghana, the National Archives has yet to catalog documents held by the Public Records Office from 1979 onwards. Many documents also appear to have been ñoverlookedò by the Public Records Office and Information Services Department in the transition to democracy in 1992. Documents remained in the offices of state executives or in private hands. Many documents were destroyed following the transition to a new party in the 2000 election, by both the in-coming party and those in the
} 


\section{Section 4. Current Approaches to Land Violence}

The theoretical debate over land-related violence causes division between neoclassical, agency and structural scholars, though some of the theories overlap. Variants of neo-classical theory situate land violence in the discussion on land-tenure institutions. Weak land tenure regimes and low tenure security, particularly in a climate of land scarcity, produce land-related violence. A history of ethnically biased distribution of state resources and unequal access to land may contribute to large-scale land conflicts by creating grievances that culminate in violence between ethnic groups. ${ }^{25}$ Neo-classical scholars advise land policy institutions to consider issues of inequality between ethnic groups, but they note that inequity can also be sustained. ${ }^{26}$ The theoryôs explanatory scope excludes the predominant and persistent cases of intra-family, intra-ethnic group, and non-ethnic- related land violence in developing countries.

The neo-classical approach holds that land-tenure security increases investments and supports the transfer of land to those who are most productive. Secure land tenure provides the basis for capitalist development and raises social welfare generally. Neoclassical theorists have departed from the position that customary land-tenure systems are impediments to modernization and should be eliminated; they now argue that traditional land-tenure systems respond to the demands of the market; customary tenure naturally

outgoing party that feared retribution. I used interviews and extensive discussions with former officials to cross-check documents obtained from individuals dating to the 1980s period, many in a deteriorated state. ${ }^{25}$ K. Deininger, "Land Policies for Growth and Poverty Reduction," World Bank Policy Research Report (Oxford and New York: World Bank and Oxford University Press, 2003).

${ }^{26}$ Jean Daudelin, "Land and Violence in Post-Conflict Situations," (Ottawa: The North-South Institute and the World Bank, 2003). 
evolves into a rational land market. ${ }^{27}$ Neo-liberal policymakers, who base their policies on rational-choice theory, argue that customary land tenure systems should be encouraged to evolve in concert with the modern land-sales market and statutory property-rights institutions. In their view, titling institutions can remove communal ambiguities, leading to secure tenure that enables commercial credit markets to work. ${ }^{28}$ Land violence will fall by the wayside when secure land tenure flourishes in a free land market, according to neo-classical logic.

Agency studies reject the narrow economic rationality of rational-choice theories and neo-liberal policy, though they often agree that land tenure is evolving. ${ }^{29}$ Agency studies examine individual disputes over rural farmland at the household and village levels. Micro-level studies point to a wide array of factors that contribute to disputes. ${ }^{30}$ Actors engaged in disputes learn and adapt over time, making dispute outcomes openended. ${ }^{31}$ Agency studies tend toward anthropological and sociological theories, though they also incorporate political theories that argue that states are too weak to influence local tenure disputes. The agency approach to land violence tends to offer either low-

${ }^{27}$ J.P. Platteau, ñDoes Africa Need Land Reform?ò in Evolving Land Rights, Policy and Tenure in Africa, ed. C. Toulmin and J. Quan (London: IIED, 2000).

${ }^{28}$ G. Feder, et al., Land policies and farm productivity in Thailand (Baltimore: Johns Hopkins University Press, 1988).; Hayes, J., Roth, M., and Zepeda, L. ñTenure security, investment and productivity in Gambian agriculture: A generalized probit analysis, ò American Journal of Agricultural Economics 79, no. 2 (1997)..

${ }^{29}$ Sara Berry, ñDebating the Land Question in Africa,ò Comparative Studies in Society and History, 44, no. 4 (2002).

${ }^{30}$ P. Shipton and M. Goheen, ñntroduction. Understanding African Land-Holding: Power, Wealth and Meaning,ò Africa, v. 62, no. 3 (1992).; Sara Berry, Chiefs Know Their Boundaries: Essays on Property, Power and the Past in Asante, 1896-1996 (Portsmouth, NH: Heineman/Oxford: James Curry/Capetown: David Phillip, 2001).

${ }^{31}$ Miriam Goheen, ñChiefs, Sub-chiefs and Local Control: Negotiations Over Land, Struggles Over Meaning,ò Africa 62, no. 3(1992).; Rie Odgaard, ñScrambling for Land in Tanzania: Process of Formalisation and Legitimisation for Land Rights, ò in Securing Land Rights in Africa, eds. Tor A. Benjaminsen and Christian Lund (London: Frank Cass, 2003). 
level causal generalizations or no resolution at all. Agency studies emphasize the singularity of each case, underestimating political power in emerging patterns of land violence.

Structural scholars examine global political and economic trends that are mediated by domestic institutions and social relations. They discuss land-related violence in the context of social and economic transitions to capitalism. ${ }^{32}$ Structuralists argue that the demand for land increases as global capital penetrates African countries, predominantly through recent structural adjustment programs. Higher demand increases land values, and market competition increases social inequality. Peasants lose their access to land as the bourgeoisie use their links to the global market to increase their access. ${ }^{33}$ The growing disparity in landholdings deepens social differentiation. Conflicts then ensue between classes over access to land. Violence tends to be sporadic, however, because the state acts in the interests of global capital and represses subaltern class actions. ${ }^{34}$

Structuralists offer general-level theories, but they underestimate the agency of domestic actors and the relevance of local institutions, while they exaggerate the importance of structural adjustment as a cause of land-related violence. The global market and external influences contribute to rising land values and spikes in demand, but these become operational only within the local historical, political, and social context. Structuralists also tend to focus on class conflict and to highlight cases in which the ruling class struggles with the proletariat, or with peasants, such as the lower classes in

\footnotetext{
${ }^{32}$ Kojo S. Amanor, ñLand, Labour and Family in Southern Ghana: A Critique of Land Policy Under Neolibearlism,ò Research Report no. 116 (Uppsala: Nordiska Afrikainstitutet, 2001).

${ }^{33}$ Moyo and Yeros, Reclaiming the Land.

${ }^{34}$ Amanor, ñLand, Labour and Family.ò
} 
Zimbabwe ${ }^{35}$ and South Africa. Few structuralists address the prevalence of intra-rulingclass disputes and violence. More attention to ruling class formation and the role of land in accumulation would sharpen the approach.

\section{Section 5. An introduction to changing land relations and political}

\section{power}

Changing imperatives and control over allocation: From pre-colonial to contemporary

Historically, ruling-class dominance has been tied to control over land and landbased resources in Ghana. The customary arrangement over land ensured dominance of the traditional, or customary, aristocracy prior to colonization. Ethnic groups and clans held land communally and considered land the property of ancestors, the living and future generations. The allodial, customary leaders held land ñin trustò for members of the group. The leaders allocated usufruct land rights according to the needs of group members and notions of social harmony. Usufruct owners did not pay cash for the land; rather, they provided a drink or offering in a ritual transfer that acknowledged communal land ownership, by the ancestors as well as by future group members. In some cases, land users made non-monetary payments in the form of labor or crops to allodial owners. Allodial owners directed subjects to a general area of land deemed appropriate to the subjectô farming needs, sometimes throwing a rock to determine size. Allodial owners could also allocate land to ñstrangers, Ò who migrated to a traditional area or as caretakers

\footnotetext{
${ }^{35}$ David Moore, "Zimbabweôs Triple Crisis: Primitive Accumulation, Nation-State Formation and Democratisation in the Age of Neo-Liberal Globalisation," African Studies Quarterly 7, no. 2-3 (2001).
} 
for outlying land through a customary process. Usufruct landholders could pass land on to heirs, but could not alienate land, because it belonged to the group in perpetuity.

Customary land relations perpetuated the status quo relationship between a ruling traditional aristocracy and the subjects of that aristocracy. Control over land allocation provided the primary means with which the aristocracy could exercise control over subjects. In turn, subjects remained loyal to the customary aristocracy in return for continued access to land for subsistence. Conflicts over land tended to be between customary groups over boundaries in which customary subjects defended their customary land or attempted to expand it.

Relations over land in Africa changed with the spread of capitalism to specific areas or enclaves. Coastal African communities began to alienate land to European merchants with their arrival centuries ago. The Ga children, in Accra, Ghana, still reenact intra-Ga battles touched off when the customary leader Wonzee sold land to a Dutch trader in the $16^{\text {th }}$ century. The $19^{\text {th }}$ century cultivation of cocoa in the Gold Coast for the world market heralded closely studied changes in land relations in Akan hinterland areas. ${ }^{36}$ Land has been commoditized in stages in a similar manner across Africa, but not with the levels and nature of the violence seen in contemporary societies. The commoditization of land changes both the livelihoods of communal subjects and local social relations. Control over the allocation of resources shifts away from

\footnotetext{
${ }^{36}$ See for examples: Polly Hill, Migrant Cocoa Farmers of Southern Ghana: A Study in Rural Capitalism (Cambridge: Cambridge University Press, 1963).; R. Addo-Fening, "Chieftancy and Issues of Good Governance, Accountability and Development: A Case Study of Akyem Abuakwa under Okyenhene Ofori Atta I, 1912-1943," in Chieftancy in Ghana: Culture, Governance and Development, ed. Irene K. Odotei and Albert K. Awedoba (Accra: Sub-Saharan Publishers, 2006).; R. Addo-Fening, Akyem Abuakwa 17001943: From Ofori Panin to Sir Ofori Atta (Trondheim: Norwegian University of Science and Technology, Faculty of Arts, 2000).
} 
allodial owners who act on behalf of subjects and hold a traditional stake in the land, to individuals who are motivated by profits. Allodial owners discontinue the customary practice of allocating land to subjects based on communal or familial relations. They no longer determine plot size or location based on subsistence-farming needs; instead, they transfer larger tracts according to the market price, though this is still referred to as a ñdrink price.òCommunal subjects lose access to that land for subsistence and small-scale farming as more land is sold outright or leased for long periods, commonly 50-99 years. Subjects who are forced off the communal land by financial strain and coercion often migrate to regional towns or cities. This process of the primitive accumulation of land by non-communal subjects marks a transition from pre-capitalist relations to capitalist relations. The imperatives shift away from the pre-capitalist notion of access to resources, which is characterized by a communally acceptable distribution of property and wealth and the right of all to access to a means of self-reproduction. The capitalist imperatives of competition replace the pre-capitalist mode, under which individuals compete for access to resources irrespective of basic subsistence needs or acceptability to the overall community. ${ }^{37}$ This process of change in social relations built around land alters the power configuration, separating the groups who become the beneficiaries of land resources from those groups which are excluded.

\section{$\underline{\text { Land and Political Power }}$}

\footnotetext{
${ }^{37}$ Michael Perelman, The Invention of Capitalism: Classical Political Economy and the Secret History of Primitive Accumulation (Durham and London: Duke University Press, 2000).; Ellen Meikins Wood, The Origin of Capitalism (New York: Monthly Review Press, 1999). The meaning for this dissertation does not equate primitive accumulation necessarily with the process of proletarianization.
} 
A change in the configuration of land-related power transforms broader social relations by transforming the sources of power and legitimacy in society. Historically, customary rulers controlled the allocation of land and land-based resources within their territories. This control over land allocation, and the associated customary payment of drinks, crops and labor, gave allodial ñowners," usually traditional chiefs, priests and clan elders, a great deal of power over subjects. Pre-colonial customary rulers also had the means to gain legitimacy. Chiefs and elders could offer services such as arbitrating disputes and organizing customary rituals in exchange for taxes and labor. It is important to note that subjects could counter the power of leaders by removing those leaders over the violation of customary restraints, including abuse of power over land allocation or use.

The introduction of a national state, and its intervention in customary affairs, altered the basis of the chiefôs power and the customs in place to check the exercise of that customary power. The British colonial strategy of indirect rule incorporated chiefs into an administrative framework and devolved administrative duties to them. If necessary, the British created chiefs where there were none. ${ }^{38}$ Colonial administrators also consolidated customary power under a hierarchical system of territorial paramountcy. At times, this meant creating new paramount chief positions where none had existed, or placing a paramount chief over a lower-level chief from a different ethnic group or faction. Paramount chiefs could exercise ultimate control over the allocation of

\footnotetext{
${ }^{38}$ Roger S. Gocking, "Indirect Rule in the Gold Coast: Competition for Office and the Invention of Tradition," Canadian Journal of African Studies 28, no. 3 (1994). On this process in Nigeria, see Richard L. Sklar, Nigerian Political Parties: Power in an Emergent African Nation (Princeton: Princeton University Press, 1963).
} 
resources and the collection of revenues. Paramount chiefs benefited under this system by gaining access to additional land and labor for their personal farms; they also enjoyed increased resource revenue and tributes. The colonial administration, however, assumed the power to dismiss chiefs, a right that had once belonged to the subjects. ${ }^{39}$ This dissertation adopts the view of some Africanist scholars: customary leaders are a traditional aristocracy with localized power and control over subjects that makes them a faction of the ruling class. ${ }^{40}$

The colonial version of the customary system gave paramount chiefs greater power by strengthening their control over resources and undermining the authority of other chiefs. This concentrated power in the office of territorial ${ }^{41}$ paramount chiefs created resentment and backlash among some lower-level chiefs and subjects. However, subjects had less recourse to customary means of de-stoolments they had held prior to the imposition of the colonial structure. For example, on the Ghanaian coast, the colonial authority reduced the power of traditional para-military groups, barring the asafo companies, as they were called, from their dual role of defending the customary nation

\footnotetext{
${ }^{39}$ This shift occurred in Ghana with the Native Jurisdiction Ordinance of 1878 and continued for the next 44 years. See: David Kimble, A Political History of Ghana: The Rise of Gold Coast Nationalism (Oxford: Oxford University Press, 1963). The 1904 ChiefsôOrdinance reinforced state power over destoolment and enstoolment by removing the right to appeal such decisions. See: S. S. Quarcoopome, "The Decline of Traditional Authority: The Case of Ga Mashie State of Accra," in Chieftancy in Ghana: Culture, Governance and Development, ed. Irene K. Odotei and Albert K. Awedoba (Accra: Sub-Saharan Publishers, 2006).

${ }^{40}$ Irving L. Markovitz, Power and Class in Africa (Englewood Cliffs, NJ: Prentice-Hall Inc., 1977).; Richard L. Sklar, "The Nature of Class Domination in Africa," The Journal of Modern African Studies 17, no. 4 (1979).

${ }^{41}$ Territorial rather than customary paramountcies at times meant placing divisional chiefs under paramount chiefs of a different ethnic group. Separation of these groups continues to create contention in present-day Ghana.
} 
against external forces and defending the interests of the subjects internally enforcing accountability of chiefs.

Indirect rule required for the first time that customary rulers be recognized by an external authority, which was the colonial government. This ensured that only chiefs loyal to the colonial administration remained in power. The requirement also gave chiefs the means to remain in power even when they became unpopular with their subjects. The colonial authority at times mobilized coercive state power to keep certain chiefs in position when their subjects attempted to remove them. Official recognition simultaneously made the traditional aristocracy beholden to colonial officials while shoring up the traditional aristocratsôpower over subjects. However, the changes that weakened the accountability of chiefs to subjects also weakened the legitimacy of the chiefs.

The parallel system of traditional aristocracy and state administration continued in the post-independence era. The aristocracy continued to hold onto its power over land allocation across regime changes and the transition to a capitalist economy. Chiefs historically provided the ruling class a social organization for patronage through controlling the allocation of land to clients. At the same time, the traditional aristocracy also sought to accumulate personal wealth through land revenue. This provided a means through which members of the traditional aristocracy could educate their families, enter into trading, and gain access to the ruling class factions that controlled state power.

The ruling class continued to use land as a tool in indirect rule and patronage in the post-independence state. The state supported the power of the traditional aristocracy 
over peasants in land relations, but also pressured chiefs to allocate land to political clients. Then the ruling class began to alter its approach to controlling land, notably in the 1970s. It manipulated state institutions and state-owned financial institutions to acquire land directly; this sped up primitive-land accumulation by the political ruling class, undermined customary land relations, and provoked social tensions and local resistance. The ruling class turned to the coercive apparatus to attempt to contain related land disputes and tensions.

Customary constraints on the allocation and use of land no longer applied after land was transferred as a commodity to an individual outside the clan or communal group. Individuals began to compete for land from chiefs and to retain the land, even despite challenges from disgruntled subjects and/or other individuals in the market. Customary subjects lost access to land and were forced into the ñ compulsion of the marketòto seek wage labor or informal sector subsistence. They migrated to urban areas away from the clan and the domain of their chief. As a consequence, the traditional aristocracyôs relationship with subjects became strained. The weakened legitimacy of the chief further encouraged him to sell land to gain personal wealth with which he might defend his position. With this change in land relations, the role of the traditional aristocracy changed; it increasingly lost political value as a provider of clients, and it has become more instrumental in the ruling classôs scramble for land and land-based resources.

The ruling class has not expropriated and accumulated the majority of land in Ghana - yet. The ruling class has stopped short of using control over the state to declare a 
total conversion of all land to state or individual ownership. A divided ruling class and its factional competition for power lead it to employ contradictory strategies with regard to land. On the one hand, primitive accumulation of land has enabled members of the ruling class to build personal wealth and political power. But at the same time, the ruling class factions have relied on alliances with the traditional aristocracy to build patron-client networks central to their struggle for dominance. Outright expropriation of land would undermine support from the chiefs. In short, the ruling class attempt to accumulate land through the apparatus of state power has been circumscribed by its need for political support from the chiefs to wage its internal struggles. Consequently, the transition to a market in land has been incremental, and at times, politically explosive.

\section{Section 6. A Preliminary Look at the Ghana Case}

The case shows that disputes and land violence occurred across all periods examined, including prior to and after structural adjustment. In the 1970s, disputes rose after the ruling class faction in power began appropriating and allocating customary lands to favored patrons. Violence ensued between peasants deploying primitive methods of resistance and state coercive bodies enforcing land transfers. In the 1980s, a new ruling class faction in control of the state sought support from subaltern classes so changed the approach. They used state coercive institutions to enforce land rights of subalterns and targeted violence at the traditional aristocracy and rival ruling class factions. Land violence declined temporarily during that period, but rose again with the transition to multi-party elections. Under democracy, ruling class factions used land for primitive 
accumulation and financing party politics. Land violence increased, and also became more destructive and deadly. The ruling class engaged dispossessed subalterns in land militias to wage violent fights to acquire and defend land to which they had no customary ties. Across the periods examined, disputes levels and the nature of violence over land fluctuated as the ruling class altered policies and institutions to achieve its political aims.

The global economic crisis of the 1970s reduced the availability of state finances for rulers to distribute as patronage and for personal accumulation. In the absence of abundant state resources, land became an alternative resource in the ruling-class strategy of political survival and building personal wealth in Ghana. The officials and allies of the National Redemption Council, which came to power in a 1972 coup, sought to expropriate both state-held and communal lands. State-owned banks backed ventures in commercial agriculture for state officials and their clients. This expropriation of land by senior military officers and other patrons of the government led to violence. Subaltern classes engaged in violent methods, but were disorganized and unsophisticated in the ways of warfare. Clan groups and youth organizations engaged in sporadic vandalism, destruction of farms, and physical attacks on the new land holders. In turn, the ruling class deployed state coercion to enforce specific, individual title changes, suppressing the resistance to its accumulation. Very quickly, a new popular discourse emerged condemming the commodifcation of land and reaffirming communal values.

Violent confrontations over land continued leading up to a coup on 31 December 1981 by the Provisional National Defense Council (PNDC). The PNDC capitalized on the tensions over land and incorporated land into their strategy to build support among 
the subaltern classes. State coercive bodies linked with local customary youth groups identified ñightfulò owners and returned land to subaltern class control. The PNDC also used state coercive bodies to quell local violence over land and to suppress the rival factions. The land-sales market in peri-urban Accra and other areas of the country cooled and primitive accumulation in land slowed. Land violence declined and the remaining violence tended to be led by the subaltern classes in alliance with state coercive institutions against the traditional aristocracy. The decline in the frequency of land disputes occurred despite the introduction of stabilization programs and structuraladjustment policies.

Ghana moved toward democracy with district administration elections in the late 1980s. The development discourse of the 1970s that favored strong government swung to an insistence by aid providers for ñgood governanceò in the 1980s and 1990s. Democracy introduced mechanisms for aid accountability, but it also provided a plausible way to enforce the hard conditions of structural adjustment. ${ }^{42}$ The new international pressures for liberal democracy coincided, in some cases, with domestic demands for the same. ${ }^{43}$ The political strategy of the ruling class in Ghana changed with the introduction of elections. It shifted away from an emphasis on dominance through an extensive coercive structure toward gaining and retaining power through patron-client relations. The ruling class

\footnotetext{
${ }^{42}$ Bill Freund, The Making of Contemporary Africa: The Development of African Society Since 1800 (Boulder: Lynne Rienner Publishers, 1998).

${ }^{43}$ Bratton and van de Walle discuss the configurations of domestic and international pressures for democracy. Though they find a prevalence of domestic demand for democratic change, their explanation for Ghana $\hat{Q}$ transition provides more a mixture of factors, including international compulsion, than in many other cases. See: Michael Bratton and Nicolas van de Walle, Democratic Experiments in Africa: Regime Transitions in Comparative Perspective (Cambridge: Cambridge University Press, 1997).
} 
reduced the coercive arm of the state as part of the process of democratization. ${ }^{44}$ It dismantled state institutions that had kept conflict over land in check, leaving gaps in the ability of the state to control violence at the local level. At the same time, the decline of the military establishment weakened border control and lethal weapons flooded into Ghana from armed conflicts to the west of Ghana in Sierra Leone and Liberia, to the north in the Tuareg rebellion in Niger and Mali, and to the southeast in the Democratic Republic of Congo across its porous borders. ${ }^{45}$

Democratization stimulated a shift in land relations in which land provided a financial resource for the ruling class to pursue its political aims. The traditional aristocracy leased large tracts of communal lands to private individuals across the country, used for quick profit and funding expensive electoral campaigns. Land also provided an asset through which to build patronage networks. At the same time, each faction sought to prevent the other from capturing the same land resources. Those with sufficient private wealth or links to public officials could access land, obtain titles and then enforce their claims with private armies ${ }^{46}$ of land guards made up of those dispossessed of their customary lands.

\footnotetext{
${ }^{44}$ The political ñoppositionò faction of the ruling class in Ghana argued strongly against continuity of the coercive apparatus, calling it undemocratic. The refusal to accept the Serious Fraud Office proposed by the National Democratic Congress government, an already scaled-back version of the PNDCôs National Investigations Committee, illustrates the argument that the ruling class, including its representatives in civil society, sought a weaker coercive apparatus.

${ }^{45}$ Ghanaôs border controls weakened particularly on the Ivory Coast and Togo borders.

${ }^{46}$ The use of this term refers to non-state armies raised by individuals, as in Charles H. Fairbanks, Jr., ñWeak States and Private Armies, ò in Beyond state crisis? Postcolonial Africa and Post-Soviet Eurasia in Comparative Perspective, eds. Mark R. Beissinger and Crawford Young (Washington, D.C.: Woodrow Wilson Center Press, 2002). This is not to be confused with the same term used by Reno to denote private corporation armies contracted out to states in: W. Reno, ñWar, Markets and the Reconfiguration of West Africaôs Weak States,ò Comparative Politics 29, no. 4 (1997).
} 
This study examines land relations across these periods within the context of the means to access power, accumulate wealth and use coercion. It seeks to explain how and why land relations changed, who benefited and who was excluded and why violence over land changed.

\section{Conclusion. The Structure of the Dissertation.}

The argument here diverges from conventional explanations of land-related violence. In Chapter 2, I discuss how the three major competing theoretical schools ï neo-classical, agency and structuralist ï explain land violence in Africa. Examining the ways in which these theoretical approaches integrate or neglect power helps to highlight the gaps in their causal arguments and to identify the basis for a more robust theory. I then return to my argument and propose a structural framework for understanding the rising conflict over land. Subsequent chapters will address the case of land conflict in Ghana by regime periods. Chapter 3 focuses on the years from 1972-79, during the NRC/SMC regime and the period of ñkalabule.òChapter 4 picks up from the military coup of 31 December 1981 that ushered in the PNDC ñrevolutionò and an era of structural adjustment. Chapter 5 discusses the changes in institutions and land relations from the time of the democratization and political liberalization of 1992 to the early 2000s. The dissertation concludes, in Chapter 6, by advancing the theoretical debate over the causes of land violence, the implications for development policy, and directions for future research. 


\section{Chapter 2. Competing Explanations for Land Violence}

"Fear has gripped residents of the twin village of Boi and Akporman ... following renewed hostilities in their 30-year-old land dispute. . there had been exchanges of gunfire between the two communities for the past three weeks, but matters got to a head on Wednesday when some people from Boi attacked residents of Akporman and wounded two people ... [the District Police Commander] said recently there was a court ruling in favour of the people of Akporman for the ownership . . ," 47

This dissertation seeks to explain the causes of the escalation of land-related violence within an overall process of change in land relations in Ghana. The literature that attempts to explicate the emerging trend of land violence across developing countries and regions provides a starting point to examine the central questions of this study. The rational-choice approach to land has the greatest impact on actual land-administration policy in developing countries, through the World Bank and bilateral aid institutions that outline project parameters and commit financial resources to land and land-institution reform. As the dominant approach in actual policy, rational choice receives the most attention here. Rational choice literature addresses the specific issue of land violence indirectly, so an examination of the broader rational-choice literature on land tenure and conflict is required. The two alternatives , the agency and structuralist approaches, attempt a more direct argument for the causes of land violence. In Section 1, the rational choice explanation for land violence is derived from the extensive neo-classical, means-

\footnotetext{
${ }^{47}$ Emmanuel Adu-Gyamerah, "Clash between Residents of Boi, Akporman," Daily Graphic, November 3, 2006, 48.
} 
end literature on land tenure, as well as from neo-classical approaches to war and violent conflict. Sections 2 and 3 review the agency and structuralist explanations for land violence. Finally, Section 4 introduces the class argument put forward in this dissertation.

\section{Section 1. Rational Choice Theories and Land}

The rational choice literature on land focuses primarily on land tenure institutions and their role in capitalist development. Rational choice tends not to provide a direct causal argument for violence over land. ${ }^{48}$ A detailed analysis of the rational choice literature is warranted because of its substantial influence on donor-sponsored neo-liberal policy. The arguments on land violence, in particular, need to be explicitly unwoven from the more general position on land and property rights.

\section{The Means-End Approach to Violence}

The neo-liberal literature analyzes violence from the theoretical base of endsmeans rationality consistent with methodological individualism. Rational individuals choose between producing and appropriating to maximize their profit; they may therefore choose violence. Conflict occurs when it is more profitable to appropriate through violence than it is through engaging in peaceful market exchange. Actors effectively invest in force to gain returns. The analysis aims at observing the variables through which an agent chooses violence.

\footnotetext{
${ }^{48}$ Given the limitations of space, the critique will focus only on the causal argument for land violence. A more thorough review of the rational-choice literature on war is found in: C. Cramer, ñHomo Economicus Goes to War: Methodological Individualism, Rational Choice, and the Political Economy of War,ò World Development 15 (2002).
} 
The rational choice debate in the context of impoverished Africa can be coarsely summed up as a battle between factors of greed and factors of grievance. Greed-factor arguments emphasize the interaction between the availability of primary-commodity booty, the availability of opportunities for nonviolent economic gain for male youth, and the probability of success in obtaining ñthe lootò for the youth. ${ }^{49}$ This is sometimes considered the ñcommodity curse, òbecause violence is said to rise with the availability of commodities to exploit. The other side of the debate argues that ethnic inequality is the cause of conflicts since one group may feel excluded from resources. State failure to redistribute resources along ethnic lines may create grievances that lead to conflict between groups..$^{50}$

The World Bankô position on land administration now adapts the grievance theory outlined above and applies it to land conflict, after having neglected the issue of land violence in Africa for some time. The 2003 Land Policies for Growth and Poverty Reduction argues that high rates of population growth and concomitant land scarcity, combined with an historical legacy of ethnically biased distribution of state resources and highly unequal access to land, may lead to conflicts over land. ${ }^{51}$ The document goes on to say, however, that inappropriate land tenure institutions contribute to ñapid multiplication of the conflict potentialò and a ñgeneralized insecurity of land tenure that

\footnotetext{
${ }^{49}$ P. Collier, ñDoing Well Out of War: An Economic Perspective,ò in Greed and Grievance: Economic Agendas in Civil Wars, eds. Mats Berdal and David Malone (London and Boulder, CO: IDRC/Lynne Rienner, 2000).

${ }^{50}$ Jean-Paul Azam, ñThe Redistributive State and Conflicts in Africa,ò Journal of Peace Research 38, no. 4 (2001).

${ }^{51}$ Klaus Deininger, Land Policies for Growth and Poverty Reduction (Washington, D.C.: The Bank for Reconstruction and Development/The World Bank and Oxford University Press, 2003).
} 
jeopardizes the broader rule of law. $0^{52}$ The remedy proposed to prevent violence is the introduction of title institutions to remove ambiguities in communal ownership; other market-based policy interventions, such as supporting rental markets, are also suggested. The basic principle is to correct market imperfections to allow greater equity in market access to resources. Land title institutions provide the means to enable the market.

The emphasis of neo-liberal policy on land tenure institutions is not surprising, even in recent analyses of conflict and violence. The focus has been consistently on individual property rights and titling institutions. As one World Bank consultant in Ghana insisted, titling is really the only issue, because effective titling is expected to eliminate violence. ${ }^{53}$ Reviewing the neo-classical position on titling and land tenure further improves an understanding of the rational choice position on land-related violence.

\section{Land Tenure and the Market}

The arguments for land tenure institutional reform and the more specific causal explanation for land conflict share the same theoretical assumptions. The World Bank and bilateral donor policy positions derive from the neo-classical theory of land tenure and individual property rights. The neo-classical position has gained significant influence over land management in Africa through donor conditionalities on land administration and through increased donor funding for academic research in land tenure and land conflict. Donor-led land tenure reform programs are expanding rapidly across African

\footnotetext{
52 Ibid., xli.

${ }^{53}$ World Bank consultant, personal communication, Accra, 2006.
} 
countries, ${ }^{54}$ with the World Bank alone continuously increasing lending for land institution reform, valued around $\$ 1$ billion for 25 projects from 2000-04. ${ }^{55}$

The World Bank now acknowledges land conflicts, but the approach to the problem remains largely unchanged from the earlier neo-classical position. In the 1975 Land Reform Policy, the World Bank argued that antiquated, customary land systems hindered economic development. Peasant groups allocated land irrationally, based on communal ties and a concern for social harmony, rather than according to productivity. ${ }^{56}$ Groups and community members used the land inefficiently, because traditional land tenure institutions failed to provide security and incentives for investment. ${ }^{57}$

Alternatively, modern land markets had individual title registration and boundary demarcation that provided both security and the incentives to invest in productivity and allocate land efficiently. The modern land market transfers land to those most able to extract its highest value. Modern title institutions could therefore advance commercial agriculture, ñncreasing agricultureôs contribution to social well-being..$^{58}$

The World Bank turned this neo-classical theoretical position into development policy. It proposed a policy framework that would improve agricultural productivity through state intervention in land tenure. The mandatory introduction of individual land

\footnotetext{
${ }^{54}$ For a review of shifts in land tenure programs in the aid community: Toulmin, C. and Julian Quan, eds. Evolving Land Rights, Policy and Tenure in Africa (London: DFID/IIED/NRI, 2000).

${ }_{56}^{5}$ Deininger, Land Policies for Growth.

${ }^{56}$ George Dalton, ñTraditional Production in Primitive African Economies, ò Quarterly Journal of Economics 76, no. 3 (1962); David J. King, ñLand Reform and Participation of the Rural Poor in the Developmental Process of African Countries.ò Land Tenure Center Report No. 110, Land Tenure Center, University of Wisconsin-Madison, 1973.

${ }^{57}$ Omotunde E. G. Johnson, ñEconomic Analysis: The Legal Framework and Land Tenure Systems,ò Journal of Law and Economics 15, no. 1 (April, 1972).

${ }^{58}$ Richard L. Barrows and Michael Roth, ñLand Tenure and Investment in African Agriculture: Theory and Evidence,ò The Journal of Modern African Studies 28, no. 2 (June, 1990).
} 
title registration, the World Bank argued, would jumpstart capitalist agriculture through increased tenure security, increased incentives for investment, and decreased transaction costs.

The World Bankês policy position then shifted to accommodate an alternative view of customary institutions as market-responsive. ${ }^{59}$ Theorists such as Ault and Rutman argued that when land becomes scarce, individuals in the customary tenure system respond rationally to economic incentives, contributing to a natural evolution of the land market. ${ }^{60}$ This followed Boserupôs ground-breaking work that suggested land rights evolve in response to growing pressure on land from population growth or agricultural commercialization. ${ }^{61}$ Land rights develop toward individualization as land becomes increasingly scarce, making farmers more willing and able to invest. The World Bank began to accept parallel reform programs that strengthened both state titling institutions and the evolving customary land tenure institutions. The World Bankôs policies continued to present traditional institutions as problematic because inadequate

${ }^{59}$ K. Deininger, The Evolution of the World Bank's Land Policy (Washington, DC: World Bank, 1998). For a critique of the general shift in the Bankôs program positioning, see: D. F. Bryceson and L. Bank, r̃End of an Era: African Development Policy Parallax, Ò Journal of Contemporary African Studies19, no. 1 (2001).

${ }^{60}$ D. E. Ault and G. L. Rutman, ñLand Scarcity, Property Rights and Resource Allocation in Agriculture: Eastern and Southern Africa,ò South African Journal of Economics 61, no. 1 (March 1993).; See also their earlier article: Ault, D. E. and G. L. Rutman, ñThe Development of Individual Rights to Property in Tribal Africa,ò Journal of Law and Economics 22, no. 1 (April 1979).

${ }^{61}$ R. Noronha, A Review of the Literature on Land Tenure Systems in Sub-Saharan Africa (Washington D.C., The World Bank, 1985).; R. E. Downs and S. P. Reyna, eds., Land and Society in Contemporary Africa (Hanover: University of New Hampshire/London: University Press of New England, 1988).; S. Migot-Adholla, et al., ñIndigenous Land Rights Systems in Sub-Saharan Africa: A Constraint on Productivity?ò World Bank Economic Review 5, no. 1 (1991); J. P. Platteau, ñLand Reform and Structural Adjustment in Sub-Saharan Africa: Controversies and Guidelines,òFAO Economic and Social Development Papers, no. 107 (Rome: FAO, 1992).; J. P. Platteau, ñThe Evolutionary Theory of Land Rights as Applied to Sub-Saharan Africa: A Critical Assessment,ò Development and Change 27 (1996); T. J. Bassett and D. E. Crummey, eds., Land in African Agrarian Systems (Madison: University of Wisconsin Press, 1993).; Pauline Peters, Dividing the Commons: Politics, Policy and Culture in Botswana (Charlottesville: University of Virginia Press, 1994). For a review of the theory of land rights evolution in Africa, see Platteau, ñThe Evolutionary Theory of Land Rights.ò 
land records and boundary demarcation caused ambiguity about ownership. ${ }^{62}$ Enhanced investment remained the aim of policy through clear property rights and an institutional framework that guarantees security. Means of this guarantee include the removal of ambiguities in land ownership and boundaries and increased efficiency, facilitated by transferability of land rights in sales and rental markets.

In the 1990s, the World Bank introduced ñgood governanceò into its programs towards improving implementation of policy. The neo-classical theoretical position and dominant liberal-democracy paradigm presented the free market and the democratic form of government as mutually reinforcing, a ñvirtuous circleò. Deininger and Binswanger highlighted the emphasis on governance and suggested the steps required prior to systematic awarding of land titles including: increased ñaccountabilityò of local leaders, a transparent and viable legal basis, and institutions to adjudicate boundaries. ${ }^{63}$ The World Bank and other bilateral donors, such as the United States Agency for International Development, incorporated notions of good governance into land administration reform programs and funding.

The neo-classical theory implicit in these programs is that the simultaneous growth of the market and a capitalist class will lead to demands for individual property rights. Malik and Schwab state, ñ[o]ne of the fundamental economic functions of government is to establish and enforce property rights. $0^{64}$ Rational urban capitalists

\footnotetext{
${ }^{62}$ Arun Malik and Robert M. Schwab, ñOptimal Investments to Establish Property Rights in Land,ò Journal of Urban Economics 29 (1991).

${ }^{63}$ K. Deininger and H. Binswanger, ñThe Evolution of the World Bankôs Land Policy: Principles, Experience, and Future Challenge,ò The World Bank Research Observer 14, no. 2, (1999).

${ }^{64}$ Malik and Schwab, ñOptimal Investments,ò 295.
} 
should demand from government a property-rights institution to enhance security for greater capital investment and profitability. A democratic regime enables the state to support the pursuit of profit by individuals in civil society, in part through instituting and buttressing private-property institutions. ${ }^{65}$ Such institutions emerge with democratic forms of governance and release the socially optimal outcome of the market: increased productivity and efficient distribution of resources.

The World Bank now claims to be reaching broad consensus and maximizing synergies with increased donor assistance to reform land tenure and to ñbuild capacityò of property rights institutions. ${ }^{66}$ Such statements lack persuasiveness under scrutiny.

\section{Critique of Rational Choice Approaches to Land Violence}

Violence has increased alongside the introduction of programs for institutional capacity building in property rights. Case evidence exposes the weaknesses in the neoclassical assumption of a naturally occurring land-market evolution and the simplified solution of documented titles. Cases suggest that titling does not necessarily enhance security and can actually deepen inequity and insecurity in the land market. Multiple studies of Kenya found that titling increased inequity and landlessness, securing land rights primarily for the influential urban elite. ${ }^{67}$ The Firmin-Sellers and Sellers study of

\footnotetext{
${ }^{65}$ This neo-classical position is reflected in some endogenous democratization theories. See David Leblang, ñProperty Rights, Democracy and Economic Growth,ò Political Research Quarterly 49, No. 1 (1996).

${ }^{66}$ Deininger, Land Policies for Growth.

${ }^{67}$ M. Kirk, ñThe Context for Livestock and Crop-Livestock Development in Africa: The Evolving Role of the State in Influencing Property Rights over Grazing Resources in Sub-Saharan Africa,ò in N. McCarthy, et al., Property Rights, Risk and Livestock Development in Africa, International Symposium on Property Rights, Risk and Livestock Development, Feldafing, Germany, September, 1998. ; T. C. Pinkney and P. K. Kimuyu, ñLand Tenure Reform in East Africa: Good, Bad or Unimportant?ò Journal of African Economies
} 
Cameroon found that most titles were awarded to state elites and businessmen, with only $6 \%$ of title applicants successfully navigating the titling process. ${ }^{68}$ All farmers interviewed in the study of Cameroon reported that their land rights had been threatened and that titling did not increase security ${ }^{69}$ The titling of a land market leads not to a peaceful exchange, but to heightened insecurity and increased social tensions, whether through mandatory titling or through the emergence of individual land rights from the customary system.

The increased insecurity of land-holding during the emergence of a titled landsales market creates the conditions for individuals to seek private, coercive means to defend their own interests and establish their own land security. This turn toward ñself helpò in land security further suggests the failure of good governance policies in titling institutions. African capitalists defied the expected behavior outlined in neo-classical models. Many land investors do not pressure government to strengthen institutions and enforce property rights. Capitalists often avoid formal institutions altogether and choose to operate outside the parameters of the state. Studies of the land market in Ghana found that investors avoided state institutions even if that meant decreased access to the formal

3, no. 1 (1994).; J. K. Green, r̃Evaluating the Impact of Consolidation of Holdings, Individualization of Tenure, and Registration of Title: Lessons from Kenya,òLand Tenure Center Paper No. 129, Land Tenure Center, University of Wisconsin-Madison, 1997.

${ }^{68}$ K. Firmin-Sellers and P. Sellers, ñExpected Failures and Unexpected Successes of Land Titling in Africa,ò World Development 27, no. 7 (1999).

${ }^{69}$ Ibid.; See also, D. A. Atwood, ñLand Registration in Africa: The Impact on Agricultural Production,ò World Development 18, no. 5 (1990). 
credit market; these studies highlighted the use of informal credit markets for land development. ${ }^{70}$

As Chapter 5 will discuss below, democracy may also fail to bring accountability to land administration, statutory or customary. Rather, the introduction of democracy coincided with deepened patronage in Ghana. Market actors used patron-client networks to gain political means to control land resources. Land disputants and competitors attempted to strengthen their positions in disputes with personal, patronage links to state officials. Patrons tilted the process of official titling to favor clients and manipulated the courts to obtain and defend informal and formal land transfers for clients. State officials used political influence over institutions to protect clientsôprivate land-guard armies from prosecution. Citizens under a democratic dispensation did not use their electoral power to resist the arbitrary interference of state officials and abuse of institutions in land matters; instead, they used ties to state officials to skew legal and violent disputes in their favor.

Neo-classical theory and land policies influence government policy through aid conditionalities. The policies have unintended outcomes because neo-classical theories separate analysis of the market from the political context in which individual actors and groups of actors make choices and operate. Land is embedded in the social structure and history of a society and is almost impossible to abstract from its political, social, ritual,

\footnotetext{
${ }^{70}$ S. Osei Kwame and F. Antwi, ñThe Impact of Land Delivery and Finance in the Supply of Residential Accommodation in the Urban Centres of Ghana: The Case Study of Accra, Tema and Kumasiò(MS Thesis no. 229, Department of Real Estate and Construction, Real Estate and Construction Economics, Stockholm, Sweden, 2004).; Tipple, A. Graham, et al., ñHousing Supply in Ghana: A Study of Accra, Kumasi and Berekum,ò Progress in Planning 51, no. 4 (2001). On Cameroon, see: Firmin-Sellers and Sellers, r̃Expected Failures and Unexpected Successes.ò
} 
and affective meanings. ${ }^{71}$ Historical and contemporary cases of the transition from traditional rights to a competitive market-based system reveal a process fraught with contention and violence. The ruling classes use political and coercive means to control land and land-based resources, denying political foes and subaltern classes, access and ownership. The neo-classical assumption of the natural emergence of a free market through unfettering opportunities and rational individual responses ignores the social structure and the struggle to control land. Neo-classical theory disassociates the market from the non-economic factors that shape the nascent land market and produce a socially sub-optimal outcome.

In addition, the neo-classical argument that grievances cause land violence is also flawed. To begin, testing the soundness of the grievance theory in general is problematic, because it is not clear whether grievance factors can be accurately measured. Statistical data on land ownership, user rights, and levels of wealth across one or more ethnic groups is often woefully inaccurate or unavailable. In addition, gini-coefficients used in the statistical analysis of the theory may not provide an effective proxy for grievance factors, even assuming the data are accurate. ${ }^{72}$ The attempt to incorporate social and ethnic factors in a primarily economic theory is advantageous, but the limitations of the data and of the proxy variables for grievance measurement undermine the robustness of a statistical explanation for violence over land.

\footnotetext{
${ }^{71}$ Charles C. Soludo, ñComparative Institutional Development: Lessons from Rural Land Markets in Africa,ò Department of Economics, University of Nigeria, Nsukka, 2000.

${ }^{72}$ Cramer, ñHomo Economicus Goes to War.ò
} 
Apart from measurement problems, the theory also fails to specify the conditions under which the grievance explanation holds and provides no trigger mechanism for the escalation of local violence into widespread conflict. Most land disputes do not erupt into widespread conflict or civil war. Rather, they can continue for generations with only periodic violent confrontations. Scholars applied the grievance theory of conflict to explain only a narrow set of cases of land conflict in Africa, but the theory cannot account for the majority of land-violence cases.

The neo-classical grievance theory that the World Bank applied to large-scale conflicts over land ultimately fails to explain the rise and proliferation of land-related conflicts. Grievance factors cannot account for all or even most cases of violence over land. Ethnicity has become a factor in the escalation of a few land-related conflicts, but many violent disputes do not involve inter-ethnic disparity in access to land resources. Intra-ethnic land disputes tend to be overlooked as a source of persistent violence. Violent land disputes between powerful individuals or factions, in which neither side has a claim to ethnic and traditional rights of access, are also becoming more common. The grievance theory emphasizes ethnic disparity as the primary causal factor, thereby excluding a large number of cases.

Ultimately, examination of the underlying assumptions of the neo-classical theory of land tenure most effectively reveals the failure of the theory to provide an explanation for violence. Neo-classical theory does not address problems directly associated with a transitional period in land relations, because the shift in rights to land, from customary to market, is treated as an unfettering of natural impulses lying dormant. Neo-classical 
theory assumes individual land rights to be a normal part of economic development, whether they evolve in response to the market or are mandated by the state. ${ }^{73}$ Individuals released from inhibiting factors, in this case customary institutions, can act on natural market incentives and respond to individual market opportunities. The emphases of neoclassical literature on land tenure is in fact unmasking opportunity and enabling individuals to respond. For instance, Fisk and Shand argue for policies that increase the ñncentive factoròtransmitted by market forces. ${ }^{74}$ Meiksins Wood, however, has challenged this understanding of the market. ${ }^{75}$ Emphasis on opportunity and choice ignores the upheaval caused by the social transition from customary norms of land allocation to the economic compulsion of market forces. The assumption of continuity between non-capitalist and capitalist societies denies the rupture with earlier social forms and the factors that shape the emerging form. Neo-classical theory excludes a discussion of transition and the tensions and conflict that often occur with social change, because the theory assumes a naturalness of and continuity in a market of opportunities and incentives.

An alternative body of literature grew in response to such perceived failures of a simplistic rational individual theory, as well as the documentation of social devastation that followed the introduction of new titling policies and programs. Theorists sought

\footnotetext{
${ }^{73}$ William J. Barber, ñLand Reform and Economic Change Among African Farmers in Kenya,ò Economic Development and Cultural Change 19, No. 1 (Oct., 1970).

${ }^{74}$ E. K. Fisk and R. T. Shand, ñThe Early Stages of Development in a Primitive Economy: The Evolution from Subsistence to Trade and Specialization,ò in Subsistence Agriculture and Economic Development, ed. Clifton R. Wharton, Jr. (Chicago: Aldine Publishing Co., 1969).

${ }^{75}$ Ellen Meiksins Wood, The Origin of Capitalism (New York: Monthly Review Press, 1999).
} 
evidence in empirical cases to counter the assumptions of neo-classical theory, explained further below.

\section{Section 2. An Alternative Paradigm: Negotiability, Contingency and}

\section{Cultural Durability}

Agency literature also found a process of change under way in tenure relations in Africa, driven by increasing scarcity of land due to population growth, environmental degradation, and the changing position of the village in the wider economy. The new approach to the evolution of land tenure, however, differed vastly in method and analysis from the neo-classical. Agency scholars dismissed the generalization of economic theories and privileged the singularity of each case. Research focused on the contingent conjunctures of case-specific factors and the agency of individuals amid changing social relations over land.

\section{$\underline{\text { Agency in Land Disputes }}$}

Empirical studies based primarily in anthropology and sociology privileged methodological interpretivism and observer immersion in small, rural communities. Scholars brought to the center of analysis the proposition that land relations are socially embedded. Changes in land tenure represented agency in the relations among people and between people and the eco-system, not just rational responses to market incentives. Economic rationality became one of many factors that shaped land-related social relations. 
In-depth case studies provided narratives of land disputes and the actions of individuals and groups within the disputes. Agency scholars acknowledged that population growth and land scarcity may stimulate changes in land relations, but found that contestation over land tenure has multiple meanings. ${ }^{76}$ In short, land holds meaning beyond its economic use. Land intertwines with the creation and recreation of ethnic identity. Struggles over land and land tenure, including state programs of titling, are not just a contest over material resources; they are debates over the symbolic meaning of custom and tradition and group identity. ${ }^{77}$ Economic models cannot unveil the causes of disputes or predict the actions of individuals within those disputes because they reduce or ignore culture and custom.

Berry and Peters both highlight the importance of custom and the meaning of land in disputes. Individuals and groups struggle over a specific plot of land in a contest over the meaning of custom itself. The power to define the land and the group is the power to interpret or reinterpret history and to lay claim to land. ${ }^{78}$ Berry, in particular, argues for inclusion of history in understanding land relations because colonial authorities defined custom and integrated colonial meanings into socio-economic institutions that had no translatable counterparts in most African languages. ${ }^{79}$ Contemporary conflicts over land encompass long-term power struggles over the definition of custom and meaning, not just a drive for profit.

\footnotetext{
${ }^{76}$ Berry, ñDebating the Land Question in Africa.ò

${ }^{77}$ Donald S. Moore, ñClear Waters and Muddied Histories: Environmental History and the Politics of Community in Zimbabweôs Eastern Highlands,ò Journal of Southern African Studies 24, no. 2 (June, 1998).

${ }^{78}$ Sara Berry, ñHegemony on a Shoestring: Indirect Rule and Access to Agricultural Land,ò Africa 62, no. 3 (Jul., 1992).

${ }^{79}$ Berry, ñDebating the Land Question in Africa.ò
} 
While the agency literature contributes to the debate by highlighting complex social factors, the emphasis on individual action within a local process of change in land relations denies overarching patterns of power relations that favor dominant classes. It finds that evolving customary institutions ultimately do not have predictable winners and losers because beneficiaries and losers of land disputes are under continual negotiation in the flexible customary system. ${ }^{80}$ Agency scholars such as Berry recognize that skewed power structures during the colonial period gave the colonial administration great influence over customary leaders and their subjects in land relations. However, they argue that flexible social relations within the customary system allow every individual and group some room to exercise power in disputes. Individual actors in land disputes interact, learn from their experiences, and adapt to constantly changing circumstances. Disputants form new strategies and make new alliances with other individuals or groups to gain land or defend their existing access to land. ${ }^{81}$ For instance, peasants may choose successful strategies to resist state titling policies that do not benefit them, ${ }^{82}$ and women can resist changes or adopt new strategies to pursue their interests in customary land tenure institutions. ${ }^{83}$ Culture, customary systems, and the agency of individuals vary widely, making it difficult to identify patterns in winners and losers and power structures across customary land tenure systems. Shipton and Goheen summed up the approach in the agency literature:

\footnotetext{
${ }^{80}$ Ibid.

${ }^{81}$ Miriam Goheen, ñChiefs, Sub-chiefs and Local Control: Negotiations Over Land, Struggles Over Meaning,ò Africa 62, no. 3 (1992).

${ }^{82}$ Shipton and Goheen, ñntroduction.ò

${ }^{83}$ Leslie Gray and Michael Kevane, r̃Diminished Access, Diverted Exclusion: Women and Land Tenure in Sub-Saharan Africa,ò Special issue, African Studies Review 42, no. 2 (September, 1999).
} 
Power relations are shifting and elusive. When customary tenure rules are overlaid with national land laws, the variations and permutations are almost limitless. The rules have no set meaning; they shift according to the context and to the relationship between the various participantsôstatus, and their relationships to each other, to the customary systems, and to the state. ${ }^{84}$

Scholars deny that state actors can use their power and state institutions to dominate land-tenure disputes, and they support this assertion with the weak-state, strong-civil-society literature of political studies. Influential scholars such as Berry conclude that the African state is too weak to influence land rights or disputes at the local level. ${ }^{85}$ Institutional failures, scholars suggest, show that state and political actors are largely inconsequential to the process of changing land relations. ${ }^{86}$ Williamsôcrosscountry study of Africa argues that the failed attempts to reform land tenure and expand state control over land through registration are emblematic of the resiliency of community institutions, and, implicitly, the weak state. ${ }^{87}$ Some studies conclude that titling failures render systematic titling programs justifiable only in exceptional circumstances of extreme land scarcity. ${ }^{88}$ Institutional outcomes are inconclusive because

\footnotetext{
${ }^{84}$ Shipton and Goheen, ñIntroduction,ò 318.

${ }^{85}$ Berry, Chiefs Know Their Boundaries.

${ }^{86}$ Platteau, ñThe Evolutionary Theory.ò; Soludo, ñComparative Institutional Development.ò; Pinkney and Kimuyu, ñLand Tenure Reform.ò; D. A. Atwood, ñLand Registration in Africa: The Impact on Agricultural Production,ò World Development 18, no. 5 (1990).; Green, r̃Evaluating the Impact.ò

${ }^{87}$ Donald C. Williams, ñReconsidering State and Society in Africa: The Institutional Dimension in Land Reform Policies,ò Comparative Politics 28, no. 2 (1996).

${ }^{88}$ John W. Bruce, ñLand Tenure Issues in Project Design and Strategies for Agricultural Development in Sub-Saharan Africa,òLand Tenure Center Paper no. 128. (Madison: University of Wisconsin, 1986).; Atwood, ñLand Registration in Africa.ò; Migot-Adholla, et al., ñnndigenous Land Rights.ò̀, Mahir Saul,
} 
local land tenure institutions are primarily the result of an open-ended process of social negotiation. $^{89}$

Agency studies attempt to push the debate over land tenure and land disputes beyond the narrow view of economic rationality and efficiency to reveal deeper social causes of and responses to changes in land relations. Agency scholars conclude that the process of change in land is open-ended and in a persistent state of flux, countering the neo-classical argument that land tenure is evolving in a progressive, modernizing advance toward individual rights. ${ }^{90}$ Interpretive studies of agency identify the symbolic meaning of land, and the struggle to define custom above land, as a material resource. Agency incorporates power relations into studies but finds power relations flexible in the customary system. Land relations fluctuate, causes of disputes vary, disputes are inclusive and negotiable, and institutional outcomes are indefinite. The identification of generalizable factors and causal patterns in land-related violence is as elusive as suggesting a solution. Shipton and Goheen conclude, ñf a single lesson emerges from recent scholarship on African land-holding, it is that it is complex, variable and fluid é the inescapable policy suggestion is that it álepends. $\hat{\omega}^{91}$

ñLand Custom in Bare: Agnatic Corporation and Rural Capitalism in Western Burkina,òT. J. Bassett and D. E. Crummey, eds. Land in African Agrarian Systems (Madison: University of Wisconsin Press, 1993).; J. W. Bruce and S. E. Migot-Adholla, Searching for Land Tenure Security in Africa (Washington, D.C.: The World Bank, 1994).

${ }^{89}$ Odgaard, ñScrambling for Land in Tanzania.ò

${ }^{90}$ Shipton and Goheen, ñIntroduction.ò, Berry, Chiefs Know Their Boundaries. For a review of the literature, see Pauline E. Peters, ñnequality and Social Conflict Over Land in Africa,òJournal of Agrarian Change 4, no. 3 (2004).

${ }^{91}$ Shipton and Goheen, "Introduction," 318. 


\section{Critique of the Agency Discourse}

The agency literature serves to counter the narrow neo-classical approach and expose the complexity of land relations. However, most agency literature fails to offer a clear or generalizable explanation for land violence and conflict. Peters argues in a landmark paper that the focus on opposing neo-liberal land tenure programs creates a negotiability argument that overestimates peasant agency and fails to confront its own evidence of increasing conflict and inequality. ${ }^{92}$ Agency scholars privilege the social embeddedness of land relations and the struggle over defining the meaning of custom and ethnic identity in relation to land, giving inadequate attention to the ways in which both local and state power structures shape conflicts and impose constraints.

The agency approach suffers from a number of weaknesses. First, the methodological approach of agency hinders a full explanation for violence over land. Observer immersion studies often examine only the immediate actions of disputing individuals. Fieldwork in remote rural areas where state and political party officials have no direct, daily observable presence can lead to incorrect assumptions: that state institutions and national actors play an insignificant role in local affairs, and that community institutions are independent of the state and outside electoral politics. ${ }^{93}$ Studies therefore often exclude events, such as elections and major development projects that local notables and customary leaders, in alliance with state officials, use to gain privilege and strengthen their power over rivals.

\footnotetext{
${ }^{92}$ Peters, ñnequality and Social Conflict.ò

${ }^{93}$ Dr. Dzodzi Tsikata, Institute of Social and Scientific Research, University of Ghana, Legon, personal communication, April 2006.
} 
Second, agency scholars often repeat the mistake of neo-classical studies by examining relatively short time periods and excluding a longitudinal analysis, specifically of the political history of local institutions and their relationship to the state. Political actors and local notables in many African countries such as Ghana engaged in struggles at the local level over the form of land institutions and sought to use control over land to consolidate power during the colonial and post-independence periods. Customary leaders manipulated access to state power to pursue their interests, and state actors used state coercive bodies to support their political clients against rivalsôland claims. ${ }^{94}$ In an example from Kenya, the colonial state reformed land tenure to extend state control in an effort to subdue rebellion and customary leaders. ${ }^{95}$ The exclusion of an historical analysis of institutions, given the importance of land tenure in the historical development of African politics, limits the ability of agency to recognize the extent to which political actors and institutions shape local power relations.

Third, agency studies focus on the exercise of independent action by individuals within disputes that are part of a larger process of social change. Outcomes of disputes are not identified, because focus is on the process of dispute and the dispute is considered open-ended. ${ }^{96}$ Even where violence is observed, the conditions under which the process becomes violent are rarely addressed. The objective is to interpret meaning for each of the actors engaged in the dispute, and to broaden the discussion by integrating the cultural

\footnotetext{
${ }^{94}$ K. Firmin-Sellers, ñThe Politics of Property Rights,ò The American Political Science Review 89, no. 4 (December, 1995).

${ }^{95}$ Karuti Kanyinga, ñRedistribution From Above: The Politics of Land Rights and Squatting in Coastal Kenya,ò Research Report 115 (Uppsala: Nordiska Africainstitutet, 2000)

${ }^{96}$ Berry, Chiefs Know Their Boundaries.
} 
factors that influence social relations for each case. The approach denies causal patterns of violence across cases of disputes and fails to make generalizable statements on the triggers that escalate tensions between individuals or groups.

Fourth, agency privileges culture, and in doing so, denies the power relations that underpin customary institutions. Customary authorities often enjoy patronage links to state officials that enable them to utilize state and private resources to consolidate their social power even within a changing context. ${ }^{97}$ Chiefs in Ghana can bring or block networks of social support to state officials that can offer legitimacy; this gives chiefs a certain mediating power between state and subjects. Chiefs also must have official recognition from the state, which gives state officials leverage over chiefs. State officials often use this power to manipulate traditional courts and customary rules to pursue their own political interests and to access resources in a customary territory. The traditional aristocracy and the ruling class direct the process of change in land relations more than does the peasant, despite inclusion of peasants in dialogue over land-tenure institutions. Amanor points out that Berry focuses on the social networks around land, but says that she fails to recognize the social differentiation and to see that the elites are the most able to invest in the social networks and influence the outcomes of dialogue and disputes. ${ }^{98}$ This patron-client relationship between the traditional aristocracy and state officials links the state in local affairs and contributes to the ñdurabilityò of customary systems.

\footnotetext{
${ }^{97}$ For a discussion of the role of chiefs in African politics, see: Irving Markovitz, Power and Class in Africa (Englewood Cliffs, NJ: Prentice Hall, 1987), 153-158, 168-171; R. Sklar, ñThe Nature of Class Domination in Africa,ò The Journal of Modern African Studies 17, no. 4 (1979), 536.

${ }^{98}$ Kojo S. Amanor, ñGlobal Restructuring and Land Rights in Ghana: Forest Food Chains, Timber and Rural Livelihoods, ò Research Report no. 108 (Uppsala: Nordiska Afrikaininstitutet, 1999).
} 
Emphasis on agency and cultural durability provides a foil to economic reductionism. But, ultimately, it neglects the importance of power relations and material factors in disputes over land. The primary causal factor in land violence is usually not the struggle for meaning, even where conflicts may have an ethnic or clan identity dimension. As one scholar reflected on Rwanda, ñAll these people who were about to be killed had land and at times cows. And somebody had to get these lands and those cows after their owners were dead. In a poor and increasingly overpopulated country, this was not a negligible incentive. $0^{99}$ A more developed approach examines the layering of historical ethnic disputes with inequality between the ethnic groups; this disparity is generated by unequal power relations and access to state resources. ${ }^{100}$ This argument suggests that conflicts in most Sub-Saharan African cases can be understood better through analysis of the historical layering of ethnicity and unequal access to resources, particularly land, within the broader political economy that structures state power relations.

A few scholars dissatisfied with the theoretical limitations of agency analysis have called for recognition of the process by which interests are claimed and secured. They have asked how these interests intersect with local power relations. ${ }^{101}$ Peters calls for decreased emphasis on negotiability and more attention to large processes and r̃ broader economic and social changes taking place over the past century, particularly during the

\footnotetext{
${ }^{99}$ G. Prunier, The Rwanda Crisis, 142.

${ }^{100}$ M. Mamdani, Citizen and Subject: Contemporary Africa and the Legacy of Late Colonialism (Princeton, NJ: Princeton University Press, 1996).

${ }^{101}$ D. Tsikata and W. Seini, ñddentities, Inequalities and Conflicts in Ghana,ò Working Paper no. 5, University of Oxford Centre for Research on Inequality, Human Security and Ethnicity, 2004.
} 
past thirty or so years ... (including commodification, structural adjustment, market liberalization and globalization). $\mathrm{o}^{102}$ A useful analysis needs to identify the causal patterns of violence by addressing the historical confrontation between broader group interests without denying the interaction of individuals in the process of social change.

\section{$\underline{\text { Section 3. Patterns of Violence: Structural Arguments and Class }}$}

\section{Differentiation}

Structural analysis focuses on the role of changing class interests and relations in the violence of socio-economic transitions, departing from the methodological individualism and rational-choice approaches of the neo-classical scholars and from the local contingencies emphasized by agency studies. Structuralists seek to identify groups with clear interests in land disputes and to highlight the conflicting interests of capitalists on one hand and workers and peasants on the other. Structuralists situate local disputes over land in the context of a changing global political economy. They analyze the process by which groups pursue their interests, the formation and changing nature of the state and political institutions, and the methods by which particular groups control institutions to exclude others from acquiring resources. For instance, structuralists examine how changes to land tenure institutions and new policies on land titling affect the distribution of land resources and, therefore, increase or reduce inequality between groups. Structuralists use this approach to identify patterns in land-related violence linked to changes in the global political economy.

\footnotetext{
${ }^{102}$ Peters, ñInequality and Social Conflict,ò 270.
} 
The Causal Path: Global Capital to Local Violence

Structural scholars conclude that global capital drives changes in land relations at the local level. The causal path from global capital to violence over local land involves multiple, compounding steps. First, structural adjustment and aid conditionalities enable global corporations to extend their operations into African markets. Second, the expansion of the global market into African economies increases the demand for land for greater commodity production, which in turn escalates land values and market competition. Third, commodification of the African land market heightens inequality because peasants lose out to actors with more power, particularly global corporations or politicians with connections to the global market. The growing disparity in access to land and in land holdings deepens a process of social differentiation between classes, ${ }^{103}$ generates ñdepeasantizationò ${ }^{104}$ and fosters the emergence of a semi-proletariat in African societies. This semi-proletariat refers to a class that is simultaneously rural and urban, and active in both the capitalist, commodified market and the informal or subsistence sector, reflecting the incomplete dual processes of agrarian development and industrial development. The final step is conflict, which ensues between classes as capitalists, the semi-proletariat, and African political leaders struggle for control over land.

Scholars give prominence to the forces of globalization in altering class relations over land. Globalization drives up demand and land value at the local level. Global

\footnotetext{
${ }^{103}$ Kojo S. Amanor, ñLand, Labour and Family in Southern Ghana: A Critique of Land Policy Under Neoliberalism,ò Research Report no. 116.(Uppsala: Nordiska Afrikainstitutet, 2001).

${ }^{104}$ D. F. Bryceson, ñDisappearing Peasantries? Rural Labour Redundancy in the Neo-liberal Era and Beyond,ò in Disappearing Peasantries? Rural Labour in Africa, Asia and Latin America (London: Intermediate Technology Publications, 2000).
} 
demand and prices have risen for many traditional commodities such as cocoa and timber products, and nontraditional, high-value crops such as pineapple, fresh flowers and biofuels. A new international division in agriculture created by the center (Europe and America) forced commodity producers on the periphery to concentrate on supplying a saturated market with few traditional tropical products and new high-value crops. Moreover, growing populations competed with expanding commercial commodity producers for land, pushing up values. Structural adjustment at the same time led to cuts in state spending on social services and agricultural inputs. This action increased claims on land for subsistence. Retrenchment of workers compounded the problem. They returned to the villages to compete with agrarian-based peasants for access to land. Finally neo-liberal policies exacerbated tensions by unleashing a market-based redistribution of land that favored the elite. Ensuing rising land values increased the inequality between interest groups, with subaltern classes proving the least able to acquire land or even maintain access to subsistence-level plots. The semi-proletariat suffered the greatest loss, as structural adjustment created a resource squeeze from multiple directions, increasing the cost of social services and basic commodities, and undermining its social reproductive ability. ${ }^{105}$ It is not surprising that the semi-proletariat engaged in land squatting and occupation and violently resisted its exclusion from diminishing means of self-reproduction. ${ }^{106}$

Democracy does not figure as a progressive factor in structural arguments. Structuralists dispute the ideal of the democratic free-market paradigm, in which

\footnotetext{
105 Moyo and Yeros, Reclaiming the Land.

106 Ibid.
} 
democracy enables those disadvantaged by structural adjustment to pursue their interests effectively and to make demands on accountable leaders. Moyo and Yeros argue that neo-liberalism has co-opted both political parties and civil society groups, removing these democratic tools as effective tactical options to pursue alternative strategies of development. ${ }^{107}$ Democratic institutions effectively exclude the semi-proletariat, leaving violence as a primary option in the struggle for land. Bernstein adds to this argument by broadly concluding that in a context where the semi-proletariat lacks organized political representation, violence is generally defensive in nature. ${ }^{108}$

Scholars examined the potential of democracy to provide a mechanism for resolving grievances over land and land-based resources. Mooreôs study on Zimbabwe concluded that perverse authoritarian politicians have used violence in ostensibly democratic systems, but he left open the possibility that more genuine democratic institutions could enable greater equality. ${ }^{109}$ Moyo, on the other hand, argues that the democratic dispensation that spread with structural adjustment implicitly failed to provide a peaceful means for subaltern classes to pursue and defend their own interests. ${ }^{110}$ Amanorô study of forest areas in Ghana supports that argument, revealing cases where the state elite mobilized state coercive institutions to violently repress local resistance to

\footnotetext{
107 Ibid.

${ }^{108}$ H. Bernstein, "Rural Land and Land Conflicts in Sub-Saharan Africa," in Reclaiming the Land: The Resurgence of Rural Movements in Africa, Asia and Latin America, ed. Sam Moyo, Yeros, Paris (London and New York: Zed Books, 2005).

${ }^{109}$ David Moore, "Zimbabweôs Triple Crisis: Primitive Accumulation, Nation-State Formation and Democratisation in the Age of Neo-Liberal Globalisation." African Studies Quarterly 7, no.2\&3 (2001). ${ }^{110}$ S. Moyo, ñAfrican Land Questions, the State and Agrarian Transition: Contradictions of Neoliberal Land Reforms,òWorking Paper Series (Dakar, Senegal: CODESRIA, 2004).
} 
commodification of forestland without recourse to democratic institutions. ${ }^{111}$ Moyo concludes with the general point that the semi-proletariat has resorted to subversive, spontaneous acts of sabotage or violence to achieve its interests largely because it had few other options in the era of globalization and structural adjustment. ${ }^{112}$ Within this context, any resistance from subaltern classes is quickly suppressed by the state.

Fewer scholars address the nature of politics and patronage in Africa within the discussion about political institutions and land violence, but such studies provide a stronger explanation. In one example, Bestemen disputes tribal and ethnic causal arguments for conflict in the Jubba Valley in Somalia. Rather, she identifies linkages between global political and economic interests and the intervention and manipulation in local land relations by the domestic elite. Speculation and investment by the domestic elite precipitated by global interests ultimately led to violence between politically motivated militias in Somalia. ${ }^{113}$ Southgate and Hulme also found patronage links between local and national actors critical to the growing inequality in land relations in Kenya. ${ }^{114}$ They argue that elites pursued accumulation in land and resources through manipulation of state institutions and of local clients.

In sum, the structural causal argument for land-related violence begins with global capital pursuing and spreading commodification to African countries. This increases

\footnotetext{
${ }^{111}$ Kojo S. Amanor, "Night Harvesters, Forest Hoods and Saboteurs: Struggles over Land Expropriations in Ghana," in Reclaiming the Land: The Resurgence of Rural Movements in Africa, Asia and Latin America, ed. Sam Moyo, Yeros, Paris (London and New York: Zed Books, 2005).

${ }_{112}^{112}$ Moyo, ñAfrican Land Questions.ò

${ }^{113}$ Catherine Bestemen, Unraveling Somalia: Race, Violence and the Legacy of Slavery (Philadelphia: University of Pennsylvania Press, 1999).

${ }^{114}$ C. R. J.Southgate and D. Hulme, ñCompetition, cooperation and conflict: The dynamics of resource management in Loitokitok, Kenya,ò In P. Woodhouse, H. Bernstein and D. Hulme, eds., African Enclosures? The Social Dynamics of Land and Water (London: James Currey, 2000).
} 
demand for land and pushes up land values. Global capital interests concentrate land ownership into fewer holdings, excluding the semi-proletariat. The process of land commodification initiated by global capital leads to struggle between classes in African countries. Economic and political interests in land, the interaction of local interests with global economic changes and policy paradigms, and state political institutions and the nature of politics play a role in an increasingly violent process of commodification in land. While structuralists sharpen the debate on land conflict in Africa by incorporating global political and economic factors into generalizable causal analyses of local land violence, their approach has limitations.

\section{Critique of the Structural Arguments}

Structuralists give too much causal significance to structural adjustment in their conclusions. The causal path from structural adjustment to conflict is not clear. ${ }^{115}$ Structural adjustment may play a role in creating violent claims to land, but the causal mechanism must be clarified. In the case of Ghana, land violence occurred in the period prior to structural adjustment, tapered off after the initial period of structural adjustment, and then intensified after democratization. The role of structural adjustment in causing changes to the land market, and, ultimately, in precipitating violence, cannot be known until the period of structural adjustment is explicitly compared to other periods. Structural adjustment may be just one of a number of factors on the long path of changing social relations over land.

115 C. Cramer, Violence in Developing Countries: War, Memory, Progress (Bloomington: Indiana University Press, 2007). 
Structural studies too often fail to make the explicit links between structural adjustment, the expansion of global capital into the land market, and rising land values. It is not adequate to conclude that structural adjustment leads to global capital penetration, which in turn increases demand and values of land that cause violence. The specific means by which structural adjustment acted as a mechanism to create violence must also be identified. This requires greater attention to local historical conditions, such as specific reforms and actors. For example, in former settler colonies such as Zimbabwe, global or expatriate corporate entry in the land markets may be significant. Likewise, commodity enclaves such as timber, gold and coltan may experience high rates of global capital penetration. Structural adjustment may also enable global firms to increase participation in African markets through procurement and construction contracts. However, in each of these cases, the role of actors, economic reforms, and global capital must be defined as part of a process of rising land violence. Indeed, some land violence cases occur where direct global capital investment in land is minimal and domestic actor investment high, such as Ghanaôs peri-urban real estate development. While a general theory on changing land relations and violence is important, at the same time, the specific context within which structural adjustment operates should not be ignored.

In addition, most structural studies diminish the agency of local actors and give inadequate attention to the links, particularly patron-client networks, between the global and local actors. Many structural studies strip local political and market actors of their agency, presenting them as puppets of global capital. Structuralists too often assume that global capital interests outweigh national or local interests. Yet, scholars such as Bayart 
and Sklar have shown that local political actors are not merely the agents of global capital: ñHowever álependentôor áxtravertedôthe economy of an underdeveloped country may be, the autonomy of its bourgeoisie may yet be firmly established upon a foundation of indigenous political organisation..$^{116}$ Miliband argues that there are ñpowerful influences and constraints, from outside the state, international as well as indigenous, which affect the nature of the decisions taken; and these may well be very strong and compelling. But it is ultimately a very small group of people in the state ... who decide what is to be done or not done; and it is only in very exceptional cases that those who make the decisions are left with no range of choice at all. ${ }^{117}$

The same holds for an ñextraverted democracy.ò Structural studies tend to emphasize the dominance of global capital regardless of the local context, and, therefore, they give inadequate attention to the national state structures and variations in state institutions across cases. This suggests that African politicians, even in a democracy, are primarily concerned with pleasing external agencies and global commercial interests. These studies further assume that aid conditionalities deprive the state of sovereignty and agency. However, as Berman suggests, the state is too often presented as a structurally determined agent of metropolitan capitalism. ${ }^{118}$ This ignores the internal processes of the state and the ruling classố pursuit of its interests through local state institutions. In many cases, domestic state institutions, the domestic ruling class, and local patronage politics shape changes in land relations.

\footnotetext{
${ }^{116}$ Jean-Francois, Bayart, The State in Africa: Politics of the Belly (London: Longmans, 1993).; Sklar, ñThe Nature of Class Domination,ò550.

${ }^{117}$ R. Miliband, The State in Capitalist Society (New York: Basic Books, 1969), 67.

118 Berman, ñôA Palimpsest of Contradictionsôò
} 
Structural studies fail to demonstrate a clear causal path among globalization, structural adjustment, and violence in local land disputes. The prominent factors attributed to globalization $\ddot{i}$ high land values and inequality in land access $\ddot{i}$ are not new in African society. Rising land values and unequal land holdings in previous periods of commoditization in Africa occurred without the intensity and persistence of the current violence. Rising land values can increase competition for resources, but this may occur peacefully. Inequality in land, as agency studies show, is common, and disputes can sometimes continue over successive generations without intense fighting. The existing case evidence, rather, suggests a need to pull apart the factors and clarify the interrelationship among the global political economy, rising local land values, and inequality in land access in the intensification of violent outcomes. We need to take an historical approach that both examines a longer process of change in land relations and analyzes the recent impact of structural adjustment and democratization. We need to ask: What factors and conditions shape the changes in land relations and, more specifically, in land values and land access in Ghana? What triggers violence in changing land relations and in pre-existing and continuous local disputes?

\section{Section 4. Land Violence: A Class Argument}

\section{$\underline{\text { Land and Class Power }}$}

Land institutions and markets do not naturally evolve, but are forged in the struggle for control and power between classes, and within classes. This struggle for power and dominance in Africa is intricately tied to control over land. Class control over 
resources and power is directly related to rights to access and transfer or alienate land.

Table 2.1 below provides ideal types of landholding patterns and transfer rights related to class position. 
Table 2.1 Landholding patterns in Africa

\begin{tabular}{|c|c|c|}
\hline Class Position & Landholding patterns & Power over allocation \\
\hline Landless peasant & $\begin{array}{l}\text { No actual usufruct access to } \\
\text { an individual plot of land as a } \\
\text { customary subject }\end{array}$ & None \\
\hline Tenant farmers & $\begin{array}{l}\text { Usufruct rights of customary } \\
\text { land; exchange for percentage } \\
\text { of goods produced and/or } \\
\text { labor for customary } \\
\text { aristocracy or capitalist } \\
\text { landowner }\end{array}$ & $\begin{array}{l}\text { Cannot transfer land use } \\
\text { rights }\end{array}$ \\
\hline Subsistence peasant & $\begin{array}{l}\text { Customary, usufruct rights to } \\
\text { traditional plot; } \\
\text { Access primarily limited to } \\
\text { subsistence food production }\end{array}$ & $\begin{array}{l}\text { Right to transfer land-use } \\
\text { rights to family members or } \\
\text { heirs }\end{array}$ \\
\hline Small, capitalist farmer & $\begin{array}{l}\text { Leasehold: usufruct rights to } \\
\text { land plot above subsistence; } \\
\text { may contract for commercial } \\
\text { production }\end{array}$ & Can transfer leasehold \\
\hline Capitalist/bourgeoisie & $\begin{array}{l}\text { Leasehold: either publicly } \\
\text { owned or customary land } \\
\text { used for commercial } \\
\text { purposes, e.g. commodity } \\
\text { production or real estate } \\
\text { development }\end{array}$ & $\begin{array}{l}\text { Can transfer leasehold or } \\
\text { alienate land where no } \\
\text { customary owner has a } \\
\text { claim }\end{array}$ \\
\hline Traditional aristocracy & $\begin{array}{l}\text { Customary landholder: holds } \\
\text { all traditional state lands ñin } \\
\text { trustò for subjects; } \\
\text { may use land for personal and } \\
\text { commercial production. }\end{array}$ & $\begin{array}{l}\text { Determines allocation and } \\
\text { transfers of land, type of } \\
\text { use, time period of } \\
\text { customary usufruct rights or } \\
\text { leasehold }\end{array}$ \\
\hline State institutions & $\begin{array}{l}\text { Public landholder: holds some } \\
\text { customary lands ñin trustò for } \\
\text { subjects of traditional ñstatesò } \\
\text { and holds some publicly- } \\
\text { owned lands }\end{array}$ & $\begin{array}{l}\text { Can transfer publicly owned } \\
\text { lands; } \\
\text { Can transfer lands held ñin } \\
\text { trustò for traditional states; } \\
\text { Can determine land use, plot } \\
\text { size and lease periods }\end{array}$ \\
\hline
\end{tabular}

In Ghana, we find all the patterns of landholdings listed above, though some adaptation is necessary for actual case studies. The groups outlined in fact tend to straddle 
multiple types of land access and rights as land relations change. For instance, landless peasants are included above, despite the argument that Ghana has no landless peasants under the customary system. The 1992 Constitution upholds the customary system that grants land rights to all subjects of traditional states or clans. However, this constitutional provision is largely nominal. Increasingly, subsistence peasants are being denied access to customary land, held either by the stool or the clan. Instead, they migrate to small towns and regional or national urban centers, often to work in the informal sector. The retention of links to the customary system and the occasional overlap with subsistence farming on a small, often non-customary area to supplement non-farm income earns this group the title ñsemi-proletariatò in some literature. ${ }^{119}$ In another example, distinctions between the capitalist bourgeoisie and those in control of state institutions are often blurred in Africa. The ruling class uses access and control of state institutions to gain control of larger areas of land, both customary and public. Some retain the land for capitalist ventures, such as commercial farming, while others merely resell the land to commercial developers.

The nature of the ruling class and its multiple uses of land are central to this study. Land relations are the nexus of class relations in Africa, as classes in Africa derive power from their positions in controlling land. The struggle for that control creates both interclass and intra-class conflict. Land is primarily a tool in the struggle for ruling-class dominance in Africa, as both a material and a political resource. The ruling class uses

${ }^{119}$ Moyo and Yeros, Reclaiming the Land. 
control over land to build, or dismantle, patron-client networks. It also seeks to control land for more directly material purposes.

As Diamond has argued, land ownership in Africa provides both a security of social place and a base of wealth outside the state that allows for private accumulation and importantly, a hedge against loss of state power for the ruling class. ${ }^{120}$ The ruling class in Africa captures the land and land-based resources by straddling and controlling the state institutions and civil society organizations relevant to land allocation and holdings. This includes the chieftancy organizations that officially recognize the traditional aristocracy and the rulings of the traditional state courts; the state institutions that document and recognize land holdings (leases or ownership); and the coercive institutions that enforce the positions of the traditional aristocracy and enforce land registration and holdings. The ruling class uses the state levers of control over the traditional aristocracy to achieve two objectives. First, the ruling class seeks favorable leasehold access to pursue commercial commodity production, to exploit land-based resources, such as timber or minerals, and to develop real estate. Second, the ruling class seeks to strengthen its own grip on state power by building patron-client networks of support through the chiefs.

The traditional aristocracy continues to rely on land as a central means to retain economic and political power over subaltern classes. The traditional aristocracy derives much of its local power from controlling access to land and determining the nature of leasehold agreements. Customary subjects give loyalty to chiefs who offer land access,

\footnotetext{
${ }^{120}$ Larry Diamond, "Class Formation in the Swollen State," The Journal of Modern African Studies 25, no. 4 (1987).
} 
and subjects are effectively bound to such chiefs, providing a mechanism through which patron-client relations may be built. In addition, the traditional aristocracy uses land to further its own economic power. Chiefs put customary land into production based in part on bound labor from subjects, though the ability to extract labor from subjects in exchange for land access has waned. Chiefs also collect ñdrink feesòto purchase schnapps or gin as part of the exchange for land access, based on the traditional ritual of pouring libation as land-use rights are transferred from chief to subject. The 1992 constitution of Ghana dictates that chiefs cannot alienate customary land, but the law does allow them to perform traditional libation rites associated with land transfers for leases. Recently, the term ñdrink feesò has come to represent a market price for lease transfers to non-subjects. The traditional aristocracy uses this means to gain financially from land leases without violating the constitution or having to account for land revenues to subjects. However, the power of the traditional aristocracy to allocate and transfer land is circumscribed by the state. The registration of customary or clan land by a lessor or new owner requires the signature of a chief or the signatures of chiefs who possess official recognition from the state. This provides the ruling class with the means to control land allocations made by chiefs.

Land relations between the classes have shifted unevenly across Ghana as the production and exploitation of commodities has gradually spread across different geographical areas. The use of land as a material and political tool in the ruling classô quest for hegemony has varied historically across regimes and governments. The ruling class has used control over the state and the traditional aristocracy to obtain land to 
solidify its power and accumulate material wealth. Nkrumah sought to undermine the power of wealthy Ashanti chiefs by denying them the right to allocate land and collect land revenue. Under other regimes, the ruling class used its position to bolster the traditional aristocracyố control over land in an effort to gain support through local patron-client networks established by the chiefs. The approaches of the ruling class to land have changed across regimes, but land remains a material and political resource for ruling-class domination over the traditional aristocracy and subaltern classes.

\section{The Nature of the Ruling Class}

An investigation of the role of land in ruling-class formation and strategies to consolidate power can help to explain the forging of a violent land market. The Ghanaian ruling class relies on its organizational positioning, primarily in state land institutions, state-owned finance companies, and coercive institutions, to dominate the domestic resource of land. It straddles the private, capitalist sector in which it seeks control over land for private wealth. At the same time, the Ghanaian ruling class largely prevails over the traditional aristocracy that controls land allocation at the local level.

The fractious nature of the ruling class exacerbates tensions over land and the struggle of primitive accumulation. Each faction seeks to exclude rival factions from resources. Dominant class factions have sought to control resources to prevent rival factions from acquiring financial power that would enable a strong electoral campaign and from subsequently building a rival clientelist network to obtain access to state power. State power reinforced the ability to exclude rivals through selective, instrumental use of 
coercive institutions, the judiciary and financial institutions. Intense competition for resources and attempts to exclude other factions occurred within parties, as well as across party lines. The struggle to control resources became increasingly violent; it spread between numerous factions that sought new ways to exclude rivals from financial and patronage power. Superimposing the factional electoral politics of the ruling class on the local struggle for power and control of resources also raised the stakes for local clients. The election of patrons to positions of power provided local factions with the potential to use access to the state to consolidate their own power over rivals.

\section{$\underline{\text { Areas of Analysis }}$}

The transition in land relations has been messy and the path convoluted. This dissertation uses three primary areas of analysis to help highlight key events in the process of change that stand out as causally significant: regime threats and means of accessing power, the means of accumulation, and the means of coercion. ${ }^{121}$ Changes in these three primary areas interact to create shifts in the ruling-class strategy on land. This dissertation examines how changes in accessing power, accumulating wealth, and monopolizing violence across historical periods have altered the level of violence over land. Each area is briefly introduced and outlined below.

\footnotetext{
121 This is an adaptation of the areas that Bayart, Ellis and Hibou emphasize in their study on criminalization of the state in Africa. See: Jean-Francois Bayart, S. Ellis and B. Hibou, The Criminalization of the State in Africa (Oxford and Indianapolis: James Currey and Indiana University Press, 1999).
} 


\section{Means of Accessing Power}

Land is political and plays a role in relations among the ruling class, traditional aristocracy, and subaltern classes. Land has been used as a political tool throughout Ghanaôs history. For instance, the colonial government supported the centralized control over land by chiefs as a means to buttress the role of chiefs in their strategy of indirect rule. Likewise, the post-independence-ruling class faction in power sought to deprive chiefs of control over land in those areas that posed the greatest threat to revenues; they accomplished this by giving parallel state agencies the authority to collect land revenue. In another possible arrangement, relegating control over land to the subjects of the stool, who only nominally own the land, would, in effect, deprive the chiefs and the ruling class of power over the subaltern classes because the lower classes would gain economic power. Land, including both possession and control over its allocation, can be understood as a central locus for class relations and a tool for ruling-class dominance.

A change in the accepted means to access power also alters the threats to gaining and holding on to it. Some African countries have experienced several changes in their ways of acquiring power since independence. In the 1960s and 1970s, strategies responded to the plausible threat of a coup. This differs from strategies to gain power through a democratic election, particularly where relatively free and fair elections are broadly accepted as the only means to change government. Such shifting in the accepted means to power is occurring in Africa, particularly in Ghana. Posner and Young optimistically presented quantitative evidence of an increasing tendency in African politics to seek power through democratic institutions. The Afrobarometer suggests a 
general acceptance of the democratic dispensation as the legitimate means to access and retain political power in Ghana. ${ }^{122}$ At the same time, Posner and Young also observed that recent elections have been intensely competitive. Electoral politics now dominates the formation of ruling-class strategies for consolidating political and economic power in Ghana. This point is critical because political actors rearrange the role of land to suit the prevailing mode of acquiring power.

Politics is a zero-sum game in the context of economic scarcity, where access to the state is the only way to gain and retain both institutional and financial power. The ñgovernment entrepreneurò seeks control of the political apparatus largely as a means to control material resources. ${ }^{123}$ Control over productive forces, state programs and projects, or the informal sector can be used to increase personal wealth and build patron-client networks to reproduce control over the state. ${ }^{124}$ Democratic elections may be increasingly accepted as the only legitimate means to power, but economic scarcity raises the stakes of winning an election. The need for the rapid creation of loyal constituencies of voters has (re)invigorated patronage. ${ }^{125}$

In addition, new political actors did not necessarily emerge with the reorganized institutions created by electoral politics. The transition in Ghana was, as in other countries across the continent, supervised by incumbent leaders and set in motion by the

\footnotetext{
${ }^{122}$ Michael Bratton, ñFormal Versus Informal Institutions in Africa,ò Journal of Democracy 18, no. 3 (July 2007).

${ }^{123}$ I. L. Markovitz, Studies in Power and Class in Africa (New York: Oxford University Press, 1987).

${ }^{124}$ Thomas Callaghy, ñState, Choice and Context: Comparative Reflections on Reform and Intractability,ò in The New Realism in Sub-Saharan Africa, eds., E. Apter and C. Rosberg (Charlottesville, VA: University Press of Virginia, 2003).

${ }^{125}$ Steffan Linberg, ñtố Our Time to óChopâ Do Elections in Africa Feed Neopatrimonialism Rather than Counter-Act It?ò Democratization, 10, no. 2, (Summer 2003).
} 
old politicians. ${ }^{126}$ Old ñBig Menò either made a personal comeback or quietly supported new faces in revived post-independence parties. As Daloz observed, the wealth accumulated under previous governments provided the basis for invigorating patronage relations in the new democratic dispensation. ${ }^{127}$ New political parties formed along previous party traditions and carried forward historical, dominant-class fissures. The disjointed nature of the dominant class shaped the patronage politics that arose. Democracy did not eliminate the role of land in politics; it merely changed the role of land in the political strategy of the ruling class. Understanding changes in the path to power and the ways in which they altered the role of land in politics contribute to a better understanding of the causes of land violence.

\section{Means of Accumulation}

Retaining power and accumulating resources by the ruling class is inter-related. Therefore, changes in the ruling-class strategy to gain and retain power re-shape the ruling classế approach to accumulation. The role of land in this process has varied. The ruling class has alternated between using land primarily as a political tool and using it as a commodity for building personal wealth. The contradictions that arise from this conflicting role have created tensions in land relations. The ruling class must weaken the subaltern classes in order to acquire land because the land effectively belongs to the people, as it is held in trust for the subjects of customary stools by the traditional

\footnotetext{
${ }^{126}$ Robert Bates, Markets and States in Tropical Africa: The Political Basis of Agricultural Policies (Berkeley: California University Press, 1994).

${ }^{127}$ Jean-Pascal Daloz, ññ̄ig Menòin Sub-saharan Africa: How Elites Accumulate Positions and Resourcesò, Comparative Sociology 2, no. 1 (2003).
} 
aristocracy. At the same time, such appropriation undermines the authority of the traditional aristocracy and the ruling class. Therefore, the degree to which the ruling class incorporates land in its accumulation strategy, as a commodity, alters class relations over land. The degree to which the ruling class utilizes land in its accumulation strategy has varied largely by access to state funds.

The means of accumulation in Africa for the capitalist class have been constrained by a narrow economic base reliant on primary commodities and by the global structure of this market. These constraints pushed the post-independence ruling class toward using state resources and state revenue as its primary means to obtain wealth. The constriction of budgets in the 1970s with the debt crisis and rising imported fuel costs further limited the means to accumulate wealth in many African states. A small faction of the ruling class in Ghana temporarily avoided this constraint by printing money, lending massively to further its own interests through state-owned banks, and speculating in land and landbased resources. The introduction of stabilization and structural adjustment programs in the 1980s, alongside an expanding state coercive apparatus that sought to limit official corruption and increase state revenue, further tightened the available means of accumulation for all ruling-class factions. The 1980s in Ghana became known as the ñean yearsòï years of forced austerity and hostility to private business, not least to political opponents.

Democratization changed the dominant classôsources of accumulation in Ghana, on the surface. Democratization hastened the economic liberalization that had begun in the 1980s, entailing greater liberalization of markets, increased de-regulation of capital, 
and extensive privatization of industry. The liberalization of politics deepened an acceptance of the ñogicò of the market, informed by neo-liberal assumptions about the virtuous circle of democracy and free markets. As Fatton points out, the paradigm of liberal democracy embraces the ñaturalness and necessityò of markets as a precondition for the realization of democracy, and, as such, democratization cannot violate fundamental notions of the free market or tip the balance of power too far in favor of the underprivileged. ${ }^{128}$ If the process of democratization is going to have the support of the privileged, then private property must be inviolable. In Ghana, the old ruling classes largely controlled the process of democratization and institutional change, and reconfigured the formal institutions to deepen further the dominance of the nascent ruling class. Those in control of state institutions began to ease the tight controls placed on private business in the 1980s that heavily regulated exploitation of land and land-based resources, including the commodity trade and real estate development. As part of this process, the ruling class largely dismantled the coercive bodies of the state that had sought to enforce revenue collection and prevent official corruption. The new ñdemocraticò institutions not only reduced constraints on the market and capital, but also ensured the dominance of the ruling classes in the ensuing distributional struggle over resources.

However, economic and political liberalization did not necessarily deter the ruling class from adopting an accumulation strategy outside the state. Accumulation remained largely tied to access to state power. Scholars such as Reno and Bayart, Ellis and Hibou

\footnotetext{
${ }^{128}$ Robert Fatton, Haiti's Predatory Republic: The Unending Transition to Democracy (Boulder: Lynne Rienner Publishers, 2002), 202.
} 
argue that new forms of predation developed with structural adjustment, as those in power sought ñnew methods of economic accumulation and political control. ${ }^{129}$ Reno argues that structural adjustment turned the elite strategy to a more pernicious form of predation, to ñshadowôpolitics, Ò in an attempt to control the newly privatized and liberalized sectors, as well as the informal economy. ${ }^{130}$ Stated otherwise, the organizational bourgeoisie sought to accumulate wealth and retain electoral power by straddling the state, formal and informal sectors. They held state positions, but they also operated in the informal realm with their political clients, enabling them to sustain loyalty, even among criminals. Controlling the state apparatus also enabled factions to protect loyal clients from prosecution for illicit economic activity or illegal financial transactions associated with formal sector activity. Ghanaôs case appears to counter such a theory, at least in the early period of structural adjustment. Ghanấ ruling class moved into the óshadowsôwith the transition to electoral democracy. Land relations reflect the changes in approach to accumulation. Furthermore, changes to the coercive institutions in the dual-liberalization process facilitated the new political-survival strategies of the ruling class.

\footnotetext{
${ }^{129}$ W. Reno, Warlord Politics and African States Boulder (Boulder: Lynne Rienner Publishers, 1998).; Jean-Francois Bayart, Stephen Ellis and Beatrice Hibou, The Criminalization of the State in Africa (Oxford and Indiana: James Currey and Indiana University Press, 1999).

${ }^{130}$ Jean Francois Bayart, Africa Works: Disorder as Political Instrument (Oxford: James Currey, 1999); Reno, Warlord Politics.
} 


\section{Coercive Institutions and the Exercise of Class Power}

The ruling classes in Africa have utilized coercive institutions as a critical instrument in their struggle for dominance and as a means of accumulation. The threats to power and the ruling-class strategies to retain power have informed the configuration of the coercive arm of the state. Historically, African ruling classes used the armed forces, the police, or presidential guards to consolidate their power. Relations between the ruling classes and coercive organs constituted a key area of analysis during the postindependence period of frequent coups, but the importance of that sector has tended to be overlooked in democratization literature in Africa. This is not unexpected, as one objective of democratization in Africa is to reduce arbitrary use of force by those in power. However, the re-configuration of the coercive institutions during a democratization process controlled by the dominant class cannot be assumed to be accidental or benign. This dissertation argues that the distinctive reform of institutions of coercion and public order during the period of political liberalization is of particular importance to understanding the violence and insecurity that have followed democratization in many African countries. ${ }^{131}$ This includes violence over land, as the weakening of state institutions facilitated ruling-class extraction of both state and nonstate resources.

\footnotetext{
${ }^{131}$ In one of the few studies of insecurity following democratization in Africa, Magnusson argues that the ñucertainties of democratic processes, new and multiple centers of power and decision making, and the incapacities of weak institutions of public ordersòled to insecurity that linked democracy and disorder in public discourse. For his study on Benin, see Bruce A. Magnusson, ñDemocratization and Domestic Insecurity: Navigating the Transition in Benin,ò Comparative Politics 33,no. 2 (January 2001).
} 
Successive governments of Ghana have used state coercion to enforce uneven access to land. The colonial authority considered land a key security concern and placed the office that managed land documents within a secure area in proximity to military installations and the armory. It used force to secure the positions of select chiefs who came under threat from subjects who objected to what they considered unfair allocation of land. Post-independence governments have also used coercion selectively in land dealings. Therefore, the role of the coercive apparatus of the state is also central to understanding how land relations became increasingly violent.

\section{$\underline{\text { Conclusion }}$}

Land has always had political significance in Ghana as a potential means for accumulation and as a source of power in patronage relations. The ruling class historically used coercive institutions to intervene in land relations to serve its own interests. Rulers altered the mediating role that state institutions played in land relations as the threats to power changed, either speeding up the transition to a land-sales market or slowing changes in land relations. Land values rose in the 1970s led by ruling-class land speculation, but the shift of ruling-class interests in the 1980s suppressed land demand and the rising tensions in land relations. The ruling-class strategic response to the two interconnected processes of democratization and market liberalization in the early 1990s led to a rapid increase in land values and compounded historical contentions over land.

Increased demand for land and the creation of a land-sales market, however, did not follow a straight path to the triumph of the free market and peaceful competition. The 
transition in land relations did not represent the unfettering of natural impulses to trade in land. The change in land relations has been a complicated process in which those holding the greatest power either move the process forward rapidly or slow it down to suit their primary objectives. The nature and interests of the organizational bourgeoisie shape the transition in land relations and forge the market.

The next three chapters set out the historical, economic, and political context that shaped changes in regime strategy, from the military coups in the early 1970s and 1980s to the period of democratization of the 1990s and the electoral alternation of governments in the 2000s. In the next chapter, the dissertation begins to trace the links between political strategy, informed by the global and local political-economic context, and changes in land relations during the 1970s under the National Redemption Council and its successor, the Supreme Military Council. 


\section{Chapter 3. The foundations of a conflictual land market:}

\section{Ghana under the NRC/SMC}

"First you came with the pen; now you come with the sword." 132

Between 1971 and 1979, the National Redemption Council and subsequently renamed Supreme Military (NRC/SMC) became the dominant ruling-class faction through a military coup. Under the NRC/SMC, high-ranking military officers held positions as head of state (Col. Acheampong and then Gen. Akuffo) and as state ministers and directors. The coup ostensibly sought to save Ghana from the unpopular free-market policies of the elected Busia government. The NRC/SMC quickly attempted to build populist support and patronage clients among the military. It even built patronage links to businesspersons in the Busia faction of the ruling class it had overthrown, offering state loans, board positions, and contracts to gain their support. Ghanaians soon came to view Col. Acheampongố action as an ñamenitiesò coup. Military officers staged the coup following the Progress Partyôs cuts to the military budget and officersôbenefits, and the NRC/SMC leaders increasingly used their control over the state to create personal wealth. Popular support dwindled, and the regime relied on state coercion to remain dominant. In this chapter, I argue that the strategies of the NRC/SMC to retain power and accumulate wealth provoked conflict in changing relations over land. The new faction in

\footnotetext{
132 Jack Goody, "Rice-Burning and the Green Revolution in Northern Ghana," The Journal of Development Studies 16, no. 2 (1980), 143.
} 
control of the state sought to extend the areas in which it could accumulate wealth, beyond those of the previous regimes. It used its position in the state to pursue acquisition of land for large-scale commercial farms and peri-urban estates. Land speculation ${ }^{133}$ and demand increased rapidly during the years of Acheampong $\hat{\alpha}$ NRC and SMC rule. The NRC/SMC policies hastened land transfers from customary holdings to both state and private ownership as members of the ruling class scrambled for land. The dominant faction excluded rival factions and many in the traditional aristocracy from gaining land or revenues from land transfers. In addition, the commodification of communal land denied subaltern classes access to customary land and denied subjects their customary right to livelihood from that land. Social conflict over land began to simmer across Ghana. The NRC/SMC responded by deploying the state coercive apparatus to defend its interests in local land conflicts and to maintain its hold on power. The land sales market originated not from a naturally evolving response to ñfreeò opportunity, but through ruling-class intervention to dominate land and entrench its power. The strategies of the dominant ruling-class faction to gain greater control over land pushed the emergent landsales market onto a turbulent path.

Section 1 of this chapter examines the political objectives of the NRC/SMC and the global and domestic factors that shaped these objectives. Section 2 addresses the strategies for accumulation of wealth by the dominant class. Section 3 discusses the role of the state coercive apparatus in the mode of governance of the ruling class. Section 4 analyzes how the NRC/SMCôs strategies shaped changes in land relations and created the

\footnotetext{
${ }^{133}$ K. Konadu-Agyemang, "Structural Adjustment Policies and Housing Affordability in Accra, Ghana," The Canadian Geographer 45, no. 4 (2001).
} 
basis for a violent land market. Finally, Section 5 studies the rising social opposition against a declining coercive apparatus that led to the overthrow of the military officers by the junior ranks. Finally, the concluding section reviews changes in land relations during the period and suggests the factors that created a contentious foundation for the land-sales market.

\section{Section 1. Means to Access and Maintain Power: The Political Strategy}

Col. Ignatius Kutu Acheampongôs National Redemption Council (NRC) government publicly justified its military intervention on January 13'1972, that overthrew the civilian Busia government as a response to corruption, loss of international status and unacceptable economic policy $\ddot{~}$ particularly the devaluation of the Ghanaian cedi two weeks prior to the coup. The Acheampong regime immediately sought to gain some measure of domestic legitimacy to secure its rule. The military regime extended patronage distribution, and at the same time, used state institutions, particularly the coercive bodies, to demobilize political opponents and suppress resistance.

The Ruling Class: Repressing and Incorporating Opposing Ruling Class Faction Leaders

After the coup, the NRC initially consolidated its power by arresting and prosecuting alleged coup plotters and supporters of opposing ruling-class factions. The NRC embarked on a public information campaign in the state media to discredit Busiaôs unpopular free-market policies and promote its own ñedemptionò platform of ñselfrelianceò and ñnationalization. ÒIt also pursued opponents by arresting leaders from the 
Danquah-Busia Progress Party (PP), in 1972; from the Nkrumahist Convention Peopleôs Party (CPP), in 1973; and again from the PP, in 1974 and 1975. The NRC attempted to subdue the political threats from the CPP permanently by detaining its leaders and inaugurating committees of inquiry to sever the old politicians from their support bases. ${ }^{134}$ Finally, the SMC banned public dissent and forced the closure of the only opposition newspaper, the University of Ghanaô Legion Observer, in 1975. These attempts represented the stark attempts to eliminate opposing factions. However, the NRC/SMC also sought to co-opt support from within the opposing factions and to incorporate members of those factions into its own fold.

Col. Acheampong claimed to be departing from the Danquah-Busian policies of the National Liberation Council (NLC) and Busiâ̂ Progress Party (PP) governments (1966-1971), as well as the Nkrumahist policies of the CPP (1957-1966). He attempted to present policies as anti-imperialist and ñrevolutionary,ò such as Operation Feed Yourself. However, the NRC/SMC increasingly adopted policy positions similar to those of the NLC and PP. The NRC/SMCôs repudiation of foreign debts and ñationalizationò belied a highly favorable stance to international capital, contrary to official pronouncements. Hutchful argues that a ñsubserviently pro-Westò approach to international capital linked the NRC/SMC with the NLC and Busian governments. ${ }^{135}$ The NRC/SMC initially refused to repay supplier credits, but then renegotiated loan payments to increase loans

\footnotetext{
${ }^{134}$ Naomi Chazan, An Anatomy of Ghanaian Politics: Managing Political Recession, 1969-1982 (Boulder, Colo.: Westview Press, 1983).

${ }^{135}$ For a discussion of the similarities in economic policy between the NLC/PP and NRC/SMC, see: Eboe Hutchful, "A Tale of Two Regimes: Imperialism, the Military and Class in Ghana," Review of African Political Economy 6, no. 14 (1979).
} 
and aid from multinational and bilateral lenders as its budget crisis worsened. The NRC/SMCô 1975 Investment Decree also failed to achieve the publicly-stated goal to put Ghanaians in control of their own economy through ñationalizationò of multinational corporations. In practice, the NRC/SMC allowed expatriate management to retain control of the companies, offered numerous tax concessions, and then provided the loans for Ghanaians to purchase shares in the foreign companies. ñSelf-relianceò gave way to the pursuit of personal accumulation by the dominant faction of the ruling class.

The division between the military leaders of the NRC/SMC and the Busia faction of the ruling class blurred as the government sought to co-opt rival ruling-class factions. The Acheampong government maintained links with Ghanaians in private enterprise who had benefitted from ties to the NLC and PP regimes. In addition, the Acheampong administration did not dislodge those who had acquired privatized state enterprises or exclusive representation in Ghana for foreign firms between 1966 and 1971. It also ensured that former NLC and PP state ministers gained appointments to boards of directors for both state enterprises and private businesses. ${ }^{136}$ The new regime ultimately sought not to eliminate the Busia faction of the ruling class but to extend the ruling-class faction in control of the state to include many military officers and their cronies and families.

Populism and Patronage: Workers, Generals and Chiefs

${ }^{136}$ Hutchful provides a short list of these appointments. See: Hutchful, ñA Tale of Two Regimes.ò 
The NRC coupled the strategy of suppressing and co-opting opposing factions of the ruling class with attempts to build up its own popular support base through patronage. The 1975 Investment Decree mandated that multinational companies, such as Ashanti Goldfields, Paterson Zochonis, United African Company, Barclays Bank and others sell 40 to 55 percent of their shares to Ghanaians. The NRC/SMC also extended the areas of business restricted to Ghanaian citizens, a PP policy that excluded expatriate communities historically engaged in those sectors. ${ }^{137}$ The NRC also told the public that it was repudiating loans to foreign lenders. ${ }^{138}$

The NRC ratcheted up patronage distribution to gain the support of groups that had fomented unrest against the PP government. It used a budget surplus generated by a spike in world cocoa prices in the mid-1970s to expand state services. The regime restored the rights of trade unions, reinstated state grants to university students, and reestablished allowances and privileges to state bureaucrats, military and police officers. The Operation Feed Yourself (OFY) program also proved popular, ${ }^{139}$ particularly with the short-term increase in the production of foodstuffs that began even before OFYôs official launch. ${ }^{140}$ In addition, the NRCôs 1975 Investment Decree required that foreign-

\footnotetext{
${ }^{137}$ P. Collins and E. Hansen, "The Army, the State and the 'Rawlings Revolution' in Ghana," African Affairs 79, no. 314 (1980).

${ }^{138}$ The NRC actually failed to pay supplier credits with the prior approval of the British government and did not refuse to repay foreign loans. See: Hutchful, "A Tale of Two Regimes."

${ }^{139}$ George O. Assibey-Mensah, "Budgeting in Ghana: Innovations, Problems and Prospects," Public Budgeting and Finance 17, no. 2 (1997).

${ }^{140}$ Richard Jeffries, "Ghana: The Political Economy of Personal Rule," in Contemporary West African States, eds. D Cruise O' Brien, John Dunn and Richard Rathbone (Cambridge, New York, Melbourne: Cambridge University Press, 1989).
} 
owned companies sell shares to workers and other Ghanaians, and state banks and the targeted companies provided loans to the workers to purchase the shares. ${ }^{141}$

The NRC/SMC had to maintain the support of the military establishment to defend its hold on power, even as it built client-patron networks. The international diplomatic community had recognized all the regimes that had, through coups, come to power since independence, so the NRC could not rely on external intervention to prevent or reverse a coup against it. Therefore, the NRC attempted to bolster support among officers in the Ghana Armed Forces to decrease the threat of a coup. Col. Acheampong elevated himself to General and others in his coterie to higher ranks. Then, the NRC/SMC appointed military officers to positions as directors and executives in state institutions and state-owned enterprises. It further fortified its position by offering military officers credit from state-owned financial institutions to purchase state-owned and private properties.

The NRC re-organized the government in 1975 and renamed it the Supreme Military Council (SMC), in part to contain divisions and internal defections. The SMC extended the role of military officers in government, centralized control, and created an enclosed ruling coalition. Chazan describes the move as the ñconsolidation of coercionò in the regime. ${ }^{142}$ Gen. Acheampong protected himself and his immediate retinue by posting more officers to high-level state positions and blocking civilian access. ${ }^{143}$ For instance, he appointed military officers exclusively to be regional commissioners. Only

\footnotetext{
${ }^{141}$ Hutchful, "A Tale of Two Regimes."

${ }^{142}$ Chazan, An Anatomy of Ghanaian Politics.

${ }^{143}$ Ibid.
} 
two civilians held principal government positions under the SMC. Gen. Acheampong tried to shore up support within the police service that also posed a potential threat to power. The NRC/SMC gave senior police officers a fleet of BMW cars and anti-riot tanks. Doling out favors to military officers and the police hierarchy formed another tier of the NRCôs broader strategy of patronage.

Finally, the NRC attempted to build patron-client relations through the customary aristocracy to reach the peasants. The NRC initially increased the cocoa-producer price to benefit planter chiefs in cocoa production, primarily in the populous Eastern, Ashanti and Western regions. ${ }^{144}$ More generally, Col. Acheampong reversed the post-independence policies that Nkrumah had created in his attempt to circumscribe the power of the Ashanti chiefs. The NRC/SMC returned to and deepened the colonial strategy to gain access to resources and control local subjects through the chiefs.

Colonial administrators consolidated customary power under a system of territorial paramountcy under the indirect-rule strategy of British administrators, introduced in Chapter 1. The colonial administration worked through paramount chiefs to collect state revenue, organize communal labor, and implement new rules and regulations. Paramount chiefs benefitted from the arrangment because they could retain part of the revenues they collected. However, the creation of a customary system that concentrated power in the office of territorial ${ }^{145}$ paramount chiefs also generated resentment and backlash among some lower-level chiefs and subjects. Paramount chiefs

\footnotetext{
144 Collins and Hansen, ñThe Army, the State.ò

145 Territorial rather than customary paramountcies at times meant placing divisional chiefs under paramount chiefs of a different ethnic group. Separation of these groups continues to create contention in present-day Ghana.
} 
had not existed in much of Ghana and had not exercised such extensive power where they did exist. The colonial state bolstered the position of paramount chiefs against local resistance through a process of official recognition, and, in specific incidents, through coercive backing.

Nkrumah took an alternative position on paramount chiefs during the period of organizing for independence and as head of state. Nkrumahô Convention Peopleôs Party opposed the concentration of power in the customary aristocracy. The CPP had a twofold objective in organizing against the traditional artistocracyô control over land and resources, including cocoa. First, the CPP sought to gain support from peasants and small-hold farmers, particularly in cocoa-growing regions. Second, the CPP sought to undercut the traditional aristocracyôs revenue sources, thereby reducing its support to the rival ruling-class faction, particularly the Danquah-Busia group. The CPP passed the Local Governance Ordinance of 1951 that replaced the local native authorities with elected councils. It also created the Ministry of Local Government, effectively removing all representation by traditional authorities on local councils and quelling the participation of local administration. ${ }^{146}$ The CPP created parallel land and commodity institutions to those dominated by the paramount chiefs.

The two subsequent governments tied to the Danquah-Busian faction of the ruling class sought to reverse the Nkrumah policies that had threatened the power of the traditional aristocracy. The NLC and Busiâ̂ PP dismantled parallel state institutions and

\footnotetext{
${ }^{146}$ S. S. Quarcoopome, "The Decline of Traditional Authority: The Case of Hte Ga Mashie State of Accra," in Chieftancy in Ghana: Culture, Governance and Development, ed. Irene K. Odotei and Albert K. Awedoba (Accra: Sub-Saharan Publishers, 2006).
} 
returned power over land and local natural resources to the chiefs. The PP established a National House of Chiefs to act as a national body above the Regional Houses of Chiefs. BusiaQ̂ 1969 Constitution, Article 164 (1) stated, ñall stool lands in Ghana shall be vested in the appropriate Stool on behalf of, and in trust for, the subjects of the Stool, ${ }^{147}$ though the definition of ñappropriate stoolò varied according to the faction of the ruling class in power. The 1969 Constitution also protected communal lands from being compulsorily taken by the state. The Busia government also established a stool lands account, ostensibly to protect the chiefsôinterests against the state. Finally, the NLC removed around 200 chiefs loyal to Nkrumah, many of whom had obtained their positions during the CPP period, ${ }^{148}$ to ensure that only loyal members of the traditional aristocracy benefitted from the new protections and enhanced control over land resources.

Col. Acheampongố NRC/SMC placed more importance on chiefs in its political strategy than did the NLC and PP governments. The NRC/SMC sought the loyalty of chiefs in the absence of a broad support base. Col. Acheampong personally held the Commissioner for Chieftancy Affairs position throughout his time as head of state. The NRC/SMC tightly controlled the process of official recognition of chiefs, thwarting opponents and rewarding loyalist members of the traditional aristocracy. The NRC/SMC did not obtain the unified support of the traditional aristocracy; paramount and higherlevel divisional chiefs tended to support the NRC/SMC, while lower-level chiefs were likely to be excluded from the NRC/SMC largesse.

\footnotetext{
${ }^{147}$ Republic of Ghana, The 1969 Constitution (Tema: Ghana Publishing Corporation, 1969).

${ }^{148}$ D. Austin, Ghana Observed: Essays on the Politics of a West African Republic (Manchester: Manchester University Press, 1976).
} 
The NRC also incorporated chiefs into governance structures. The NRC/SMC gave cooperative members of the traditional aristocracy high-ranking positions at the regional and local level. For example, the NRC gave the traditional aristocracy leading positions in the regional development corporations (RDC). RDCs controlled budgetary, borrowing and policy-implementation responsibilities for each region in Ghana, thereby controlling state assistance to clients to accumulate wealth. In addition, the NRC mandated that chiefs serve on the so-called ñcharter committeesò in all villages and towns. The NRC charged the charter committees with implementing its Charter of Redemption locally, providing chiefs with another means to benefit from and distribute patronage. $^{149}$

In exchange for patronage to clients in the traditional aristocracy, chiefs offered public support for the unpopular NRC/SMC. The state newspapers regularly highlighted the support of chiefs, such as the Ga Mantse of Accra and the Asantehene of the Ashanti Region, for Col. Acheampongế various initiatives. For example, paramount chiefs endorsed re-designating Col. Acheampong as r̃Presidentò and supported the creation of a union government in the late 1970s. Numerous articles in the state dailies reported state officials meeting with chiefs, inviting them to state events, and giving them gifts. The endorsements formed part of the NRCôs strategy to increase its legitimacy with subaltern classes through the chiefs. ${ }^{150}$

\footnotetext{
${ }^{149}$ GNA, "Chiefs to Serve on Charter Committees," Daily Graphic, January 20, 1975, 6.

150 "Luke Calls on Ga Mantse," Daily Graphic, January 31, 1975, 8-9.
} 


\section{Section 2. Means of Accumulation: Global Market Shocks and Shifting}

\section{$\underline{\text { Strategies }}$}

Post-independence Ghana suffered from a narrow economic base in primarycommodity exports as well as low industrial output and productivity. The ruling class had focused its accumulation interests on state resources in that context. The post-colonial state with a low revenue base, as Sandbrook has pointed out, could not absorb all those seeking wealth through political positions. ${ }^{151}$ The ruling class, therefore, divided into antagonistic factions that sought total control over the state to capture the resources; it also sought to block rivals from the state in order to prevent accumulation through those same resources. The ruling-class factions used control over state institutions, through personal or family positions in organizations and enterprises, to attain status and wealth. For example, corruption in import licensing, appointments to the Cocoa Marketing Board (COCOBOD) and other cocoa-market agencies, and the awarding of contracts for state infrastructure development and mineral extraction rights provided ruling-class factions with a means to accumulate wealth. The ruling class increased its accumulation through low producer prices for primary commodities, low royalties on mineral and timber extraction, and high tariffs. It spent much of the wealth skimmed from state resources on short-term consumption, thereby requiring continual renewal of those resources.

World market shocks in the 1970s created budget crises that threatened the ruling class $\hat{Q}$ political survival and its means of accumulation. The global market shocks in

\footnotetext{
${ }^{151}$ R. Sandbrook, "Patrons, Clients and Factions: New Dimensions of Conflict Analysis in Africa," Canadian Journal of African Studies 5, no. 1 (1972).
} 
world cocoa prices, rising fuel costs and declining access to credit circumscribed the ability of a ruling-class faction to pillage state coffers and left the ruling class unable to rely on state revenue for its own exclusive consumption and reproduction. The ruling class had to shift political strategies and adopt new methods of accumulation, and it turned its attention toward land. In this way, global market forces indirectly increased demand and land prices as global market shocks led the ruling class to shift its strategy on land to speculation and commercial development for personal accumulation.

In Ghana, Col. Acheampongố refusal to service external debts created short-term impediments to foreign aid and suppliersôcredits. ${ }^{152}$ Global cocoa prices also plummeted in the early 1970s, just as the NRC took over the government. In addition, the NRC sought over time to accommodate members of other ruling-class factions, including the PP faction it overthrew, as well as its own military officers and regime stalwarts. Hutchful asserts that the NRC/SMC sought risk-free areas of investment for the capital controlled by existing businessmen and the new ñentrepreneurò with an economic base in the state. ${ }^{153}$ The NRC also offered multinational corporations incentives to invest in commercial agriculture to bolster state revenues from agriculture. Domestic demand for land for private commercial farms and real estate development increased. The NRC used its position in state institutions and enterprises to obtain large tracts of customary land and to transfer these to private holdings. Ruling-class control over state institutions,

\footnotetext{
${ }^{152}$ The NRC/SMC successfully renegotiated loan payments with external creditors in the mid-1970s, and multi-lateral and bi-lateral loans and aid resumed. See: Hutchful, "A Tale of Two Regimes."

${ }^{153}$ Sandbrook, "Patrons, Clients and Factions"
} 
official recognition of the traditional aristocracy, state-owned credit and financial enterprises and institutions of coercive force provided the means for land accumulation.

\section{$\underline{\text { Land Policy }}$}

The NRC/SMC did not put forward a national land policy, but it issued two major decrees. The 1972 Limitations Decree (NRCD 54) sought to secure titles and end excessive litigation over land. Then, the NRC/SMC issued the Conveyancing Decree in 1973 (NRCD 175) to improve, and ease, land transfers. In addition, the NRC/SMC set price ceilings on land transfers and rents. The NRC/SMCôs action on land sought to improve the security of private land holdings, primarily for the ruling class.

At the same time, the NRC took a cautious approach to changes in customary land institutions or land policy so as not to disturb the patron-client relationships it was attempting to build with chiefs. The Chief Justice, a political appointee, proposed vesting all lands in the state to avoid the ñsquabblesò over titles that he said were overwhelming the courts. He also discussed the need to negotiate land revenue with customary leaders to enable the new arrangement. A High Court judge repeated the suggestion to vest all lands in the state, but based his argument on circumventing ñinward-lookingò chiefs who hindered modern agriculture. ${ }^{154}$ The NRC gave prominent attention in the governmentowned media to the proposal to acquire all land, ${ }^{155}$ but it threatened the traditional aristocracy.

${ }^{154}$ GNA, "'Govt Must Take over All Lands'," Daily Graphic, April 14, 1977, 3.

${ }^{155}$ D. A. Okine, "Lands: Let All Be Vested in the State," Daily Graphic, April 14, 1977, 1 \& 8-9. 
The NRC/SMC proposed to make radical alterations to land ownership amid deliberations on whether the chiefs should support the NRCôs proposal for a union government, which would incorporate non-military, civil society leaders into a nonpartisan government. Civil society groups, however, protested against UNIGOV as a political ploy by the NRC/SMC to avoid democratic elections. The NRC sought the endorsement of the House of Chiefs as evidence of popular support. In this context, the National House of Chiefs first objected to the policy change on land, saying it could undermine ñthe native policy and social cohesion of the country. ̀̀ ${ }^{156}$ Soon after, the judicial service issued a statement claiming that the Chief Justiceô reference to lands had been taken out of context. ${ }^{157}$ The chiefs followed up by offering support for union government. The ruling class $\hat{Q}$ attempt at rapid expropriation of all lands failed because it relied for legitimacy on political patronage through the traditional aristocracy.

The NRC/SMC also avoided reform that had been recommended by the legal profession. The state could obstruct communities from legally contesting improper allocations of land by chiefs through the use of laws carried over from the colonial period of indirect rule. The law provided chiefs and clan heads with procedural immunity while they were in power, preventing them from being challenged legally and avoiding damage to the indirect-rule system of control. The immunity had precedence over the parallel customary court system, in which subjects or family members invoked customary law to

\footnotetext{
156 GNA, "Lands: Chiefs Protest," Daily Graphic, April 21, 1977, 1.

157 GNA, "The C. J. Was Misquoted," Daily Graphic, May 10, 1977, 9.
} 
challenge the traditional aristocracy. ${ }^{158}$ The NRC used laws from the colonial period on immunity to protect favored chiefs against ñdestoolmentò for failing to account to their subjects regarding land and resources held in trust. Scholars and legal experts had long criticized this legal position, arguing that it undermined the accountability of traditional authorities who held resources in trust for their subjects. ${ }^{159}$ The SMC maintained the colonial institutions, ignoring recommendations from the Law Reform Commission to enact a law to support accountability of traditional authorities to their subjects. ${ }^{160}$ The SMC ensured that the head of family or chief could be sued only to account for land and land-based resources following removal from office; this, of course, required recognition (approval) by the state. Refusal to implement reforms to improve management of land held in trust by family heads and chiefs enabled the NRC/SMC to collude with chiefs to transfer lands without interference by the peasant subjects.

The NRC/SMCôs numerous land acquisitions had far-reaching consequences. The NRC used executive instruments to expropriate lands held by customary stools and skins. The NRC/SMC failed to publish the executive instruments consistently in state dailies, making it difficult for the public to assess whether lands had been formally acquired. The NRC/SMC also lacked transparency in compensation payments for the lands, creating uncertainty over whether compensation had been paid to the traditional aristocracy. In

\footnotetext{
15812 W.A.C.A. 102 (1946); Fynn v. Gardiner (1953) 14 W.A.C.A. 260; Annan v. Kwogyirem (1975) 1 G.L.R. 291.

${ }^{159}$ Kludze, A. K. P., Ewe Law of Property (London: Sweet and Maxwell, 1973).; Daniels, W. C. Ekow, ñSome Principles of the Law of Trust in West Africa,ò Journal of African Law 6, no. 3 (September 1962): 164-178.; Journal of African Law. 165.; Kludze, A. K. P., ñAccountability of the Head of Family in Ghana: A Statutory Solution in Search of a Problem,ò Journal of African Law 31, no. 1-2 (March 1987).; Asante, S. K. B., Property Law and Social Goals in Ghana, 1844-1966 (Accra: Ghana Universities Press, 1975). ${ }^{160}$ Samuel M. Cudjoe, "The Effects of Head of Family (Accountability) Law 1985 (Pndcl 114) on Ga Mashi Head of Family" (LL. B. Paper, University of Ghana, 1989).
} 
some cases, the NRC/SMC openly transferred lands to investors for commercial interests. In addition, extensive corruption in state land management institutions, particularly the Lands Commission, enabled these state lands and properties to be transferred to private, individual holdings. The NRC/SMCÔ opaque and often corrupt practices regarding land make it difficult to determine the total number of lands transferred from customary to private holdings during the period.

\section{$\underline{\text { Agricultural land: Commercial Farms }}$}

The NRC/SMCôs land decrees supported its policy in agriculture and reflected the private interests of the dominant ruling-class faction, as well. The NRC placed rapid agricultural growth above all other economic policies, ${ }^{161}$ urging investment in agriculture and offering land concessions for production of food and raw materials. The state attempted to acquire land throughout the country to be used for commercial agricultural development. Toward that end, the NRC made calls on the traditional aristocracy, asking them to contribute land for increasing food production. ${ }^{162}$ In addition, the populist policy Operation Feed Yourself aimed to create large-scale agricultural enterprises, not to enable small-farmer food production. The NRC/SMC sought to reduce the role of the peasant farmer and to extend commercial production, placing its clients in beneficial positions.

The NRC/SMC continued the NLC/PP policy of forming partnerships between Ghanaians and international corporations, but it extended this to agriculture. The

\footnotetext{
${ }^{161}$ Donald Rothchild, "Military Regime Performance: An Appraisal of the Ghana Experience," Comparative Politics 12, no. 4 (1980).

162 GNA, "Offer Lands to Food Corp," Daily Graphic, April 1, 1975, 12.
} 
NRC/SMC argued that foreign companies had special expertise and capital to develop land. It offered multinational corporations benefits that included tax holidays, exemptions from duties on imports, and exemptions from property tax on buildings. The Acheampong government assisted the companies to acquire large tracts of land, reduced the ground rates, and guaranteed minimum prices on agricultural products. Following such inducements, the United Africa Company expanded into cotton production and invested in palm oil plantations, while the aluminum processing company Valco planned to invest in rice. ${ }^{163} \mathrm{CFAO}$, Shell International, and Ghana Commercial Bank invested in farms in the Brong Ahafo region, and a partnership between the Government of Ghana, Mengene African Textile Products, West German G.M.B. H., and Jensen Cattle of Denmark invested more than 18 million cedis in a dairy project. ${ }^{164}$ The investments held potential for high returns, given rising domestic food prices, as well as protection of domestic markets and numerous tax breaks. Some of the partnerships assumed control over the land allocated, but never implemented the promised projects.

However, Ghanaian involvement in commercial farming, especially by members of the regime, grew as well. ${ }^{165}$ Ghanaian military officers and high-level civil and public servants enjoyed preferential access to the best land, especially in newly irrigated areas. ${ }^{166}$ The NRC set ceilings on lease values for agriculture, ensuring favorable, low lease rates for commercial farms. The NRC rigorously implemented measures to suppress

\footnotetext{
${ }^{163}$ Valcoôs primary area of operation was the production of aluminum. See: Judith Marshall, "The State of Ambivalence: Right and Left Options in Ghana," Review of African Political Economy 5 (1976).

${ }^{164}$ Hutchful, "A Tale of Two Regimes."

165 Goody, "Rice-Burning and the Green Revolution in Northern Ghana."

${ }^{166}$ Hutchful, "A Tale of Two Regimes."
} 
land prices in the Accra area in its first years in power. ${ }^{167}$ It also promoted lending to commercial enterprises by expatriate and state-owned banks, such as the Agricultural Development Bank, Bank for Housing and Construction, State Insurance Corporation, and National Investment Bank. Access to state power enabled members of the rulingclass faction in power to borrow money from these banks to buy land and develop farms and houses. ñAbsenteeò farmers provided the organizational link to credit, often the only contribution made to commercial farms by members and associates of the NRC/SMC. Access to credit and state-controlled land prices limited the cost of land speculation and investment for the ruling-class faction in power. Commercial farming took off with this p̃politicalò credit. $^{168}$

The dominant ruling-class faction also used its control over the state to create markets for its produce. Personal commercial farms of the ruling-class faction in power supplied the state marketing structure at fixed prices. In turn, the public stores sold their commodities through depots close to the government ministries, at prices that were at the same time out of reach of peasants and urban workers yet accessible to state officials. ${ }^{169}$ The state officials also colluded with the Border Guards, using organizational links to state coercive institutions, to transport commodities to neighboring Francophone countries for higher prices and more easily convertible CFA currency. Those who held a state position or had close association with the ruling-class faction in power received

\footnotetext{
${ }^{167}$ P. K. Asabre, "The Determinants of Land Values in an African City: The Case of Accra, Ghana," Land Economics 57, no. 3 (1981).

168 Goody, "Rice-Burning and the Green Revolution in Northern Ghana."

${ }^{169}$ Marshall, "The State of Ambivalence."
} 
state-sponsored support to invest in the highly profitable sector of commercial agriculture, often directly flouting the laws.

\section{$\underline{\text { Real estate development: Housing }}$}

Housing policy also boosted land speculation for housing and estate development by the ruling-class faction in power. The NRC initially framed its housing policy as a solution to the common workerô chronic housing shortage. The state acquired various lands for ñaffordableò housing development under the auspices of that policy. The NRC announced the establishment of a housing fund at the Bank for Housing and Construction (BHC), with 70 per cent of the fund to be allocated for low-income/rural housing and a public-servant scheme. ${ }^{170}$

The Ministry of Works and Housing, particularly under Col. Kotei, drove statebacked estate development. The State Housing Corporation (SHC) had been the major producer of housing in Ghana since independence, producing around 900 single and multi-family dwellings annually. ${ }^{171}$ SHC constructed subsidized housing for civil and public servants, using state employees. However, housing demand far exceeded supply, with a shortage of around 100,000 units annually in the 1970s. The NRC/SMC altered the operations of the SHC to increase housing supply. The NRC/SMC acquired numerous unspecified lands to develop into affordable housing. ${ }^{172}$ Two areas developed rapidly: east of central Accra , at Teshie-Nungua, and west of Accra, at Dansoman. The state

170 GNA, "Housing Fund to Be Set Up," Daily Graphic, January 14, 1975, 1.

${ }^{171}$ Benjamin Bobo, "Population Density, Housing Demand and Land Values: The Case of Accra, Ghana," Journal of African Studies 4, no. 2 (1977).

172 "Housing under the N.R.C," Daily Graphic, January 9, 1975, 8-9. 
housing scheme at Dansoman, a new suburb of Accra, set out to build 550 houses in five months, with a required deposit of between 1,000 and 17,000 cedis. ${ }^{173}$

Col. Acheampong also announced the creation of redemption villages, as part of the populist strategy to gain legitimacy. The NRC promoted the concept as affordable housing in villages neighboring major urban areas. The state identified and acquired land for the projects, in such peri-urban areas as the villages northeast of Accra, around Medina. The La Mantse claimed paramountcy over the clans and stools that held the land at Medina. It is not surprising that the La Mantse, the Chief of the La Stool, also served as a member of the NRC and extensively interfered in bending traditional hierarchies in these areas to secure project land and thereby increased his own wealth.

The NRC/SMC promoted its populist housing policy to address mounting concerns over housing shortages, but at the same time Works and Housing Commissioner Col. Kotei urged the private sector to become involved in the provision of housing. ${ }^{174}$ The NRC/SMC shifted the stateôs role from direct participation in building and renting houses to building infrastructure and allowing the private sector to build houses. ${ }^{175}$ This took two forms. First, the NRC/SMC announced the sale of state-owned homes held by the SHC, ostensibly to enable the private sector to lead the housing industry and remove the state from direct intervention in housing. Col. Kotei, the Commissioner of Works and Housing, publicly instructed the State Housing Corporation to ensure fairness and avoid

\footnotetext{
173 "Housing Scheme," Daily Graphic, April 19, 1975, 3.

174 "'Take Part in Housing Project'," Daily Graphic, January 27, 1975, 1.

175 GNA, "Housing Fund to Be Set Up."
} 
tribalism in the allocation of estate houses, ${ }^{176}$ but the warning was not enforced. In most cases, the SHC sold the homes to their occupants; in other words, to members of the NRC government. ${ }^{177}$ Those close to state power also obtained credit to purchase the houses from state-owned banks and often defaulted on payment of those loans without repercussions. Second, the NRC/SMC began to contract private builders to construct houses. Again, Col. Kotei urged the state ï though his efforts were largely futile -- to distribute contracts to builders evenly. ${ }^{178}$

The state increasingly favored the interests of private real estate developers and landlords over those of tenants and workers living in state housing. The state proposed to make the investment income in housing tax free as part of its five-year plan. ${ }^{179}$ State institutions also tended to support landlords in disputes between landlords and tenants. The state instructed tenants to vacate properties upon issuance of eviction notices from landlords. ${ }^{180}$ This stance came despite the promises by the Commissioner for Works and Housing that the NRC would act on a rent decree to help control the cost of housing for workers. $^{181}$

The NRC/SMC housing policy failed to improve the housing supply for the majority of Ghanaians. Demand for land for private houses and development of rental houses increased in the areas identified for estates by the NRC/SMC. The stateô Lands Department, in collusion with allied traditional aristocracy, allocated plots and houses to

\footnotetext{
176 Beatrice Sackey, "'Allocate Houses Fairly'," Daily Graphic, April 9, 1975, 1.

${ }^{177}$ Konadu-Agyemang, "Structural Adjustment Policies and Housing Affordability in Accra, Ghana."

178 Sackey, "'Allocate Houses Fairly'."

179 "Housing the People - Individuals to Take Part," Daily Graphic, June 13, 1976, 1.

180 "Tenants and Landlords," Daily Graphic, December 11, 1976, 3.

181 "N.R.C. To Act on Rent Decree," Daily Graphic, April 10, 1975, 1.
} 
members of the ruling government and close associates. Land in the Accra area appreciated 25 percent annually from 1976-78. ${ }^{182}$ As a result, peasants and small-holder farmers lost access to land as large tracts converted to housing and commercial zones. For instance, members of the dominant ruling-class faction obtained large areas of communal farmland in the light industrial area immediately west of the capital for commercial and housing development. In addition, the SMC largely abandoned the development of the redemption village in Accraôs peri-urban area of Medina by the late 1970s, but the interference in local land relations created disputes over land allocation and chieftancy. Indeed, the PNDCôs ñrevolutionary committeesò identified Medina as a hotbed of land disputes and conflict in the early 1980s.

To summarize, the ruling-class faction in power used its position in the state to manipulate land prices, to coerce or co-opt members of the traditional aristocracy to transfer land to state and private interests, and to secure favorable credit from state development banks or with state guarantees. However, the dominant ruling-class factionôs strategy to accumulate land from customary holdings and to develop patron networks through the customary leaders was ultimately inconsistent and contradictory. The moves by the NRC/SMC to gain large tracts of land antagonized members of the traditional aristocracy who had been excluded by the ruling-class faction in power. In addition, extensive interference in land allocation and in chieftancy, as well as the loss of access to land for subsistence farming, angered customary subjects. Section 3, below, will outline the ways in which the NRC/SMC used state coercion to suppress resistance and

${ }^{182}$ Asabre, "The Determinants of Land Values in an African City: The Case of Accra, Ghana." 
enforce land transfers and chieftancy positions, which in turn set the stage for a violent process of land commoditization.

\section{Section 3. State Coercion and Dominance of a Ruling Class Faction}

The NRC used the coercive apparatus in its attempt to consolidate the power of one ruling-class faction. The NRC/SMC crudely issued a public order to soldiers to

support and defend the NRC government. ${ }^{183}$ This section examines the ways in which the $\mathrm{NRC/SMC}$ used coercive institutions to further its political and accumulation strategies, including its interference in state coercive institutions to support its interests. In particular, the section outlines the NRCQ̂ use of coercive institutions to pursue accumulation of land by selectively enforcing land registration and by empowering the chiefs who offered the NRC/SMC land.

$\underline{\text { Patronage and Demobilization }}$

The regime sought to win over the leadership of the armed forces with patronage, to enable it to use the military to suppress internal and civilian opposition. The Acheampong government interfered in the hierarchical organization and the administration of the armed forces, intelligence services, and police to achieve its aims. The NRC/SMC used patronage rank promotions in both the armed forces and the police. It transferred senior military officers to civilian administrative positions and appointed senior military officers to para-statal bodies and revenue-generating agencies of the

183 "Support the N.R.C. - Soldiers Told," Daily Graphic, January 18, 1975, 1. 
state. ${ }^{184}$ In addition, it attempted to secure its position through ethnicization of the intelligence services, filling these agencies with members of the head of stateôs ethnic group. ${ }^{185}$ The NRC publicly criticized corruption within the Border Guard, but failed to act. Effectively, the NRC enabled its own officials and the Border Guard to collude in smuggling Ghanaian produce, such as cocoa, across the border into the Ivory Coast for higher prices. ${ }^{186}$

At the same time, the NRC/SMC sought to demobilize organized labor, the student movement and local youth groups. It sent the police and thuggish political clients to disrupt public protests and arrest student leaders, sending key leaders into hiding. The NRC/SMC also used the coercive arm of the state and its political thugs to attempt to disrupt meetings and discourage strikes organized by the Association of Recognized Professional Bodies. It also deployed military personnel to patrol communities in army vehicles to intimidate the opposition among subaltern classes.

\section{Controlling Land Allocation and Land Transfers}

The military and police both enforced specific land transfers and titles in which members of the ruling-class faction in power had an interest. The same institutions also intimidated subaltern classes and youth associations that wanted to halt or prevent land transfers and that made demands to see land-revenue accounts.

\footnotetext{
${ }^{184}$ J. D. Kandeh, Coups from Below: Armed Subalterns and State Power in West Africa (New York and Hampshire: Palgrave Macmillan, 2004).

${ }^{185}$ Eboe Hutchful, "Pulling Back from the Brink: Ghana's Experience," in Governing Insecurity, ed. G. Cawthra and R. Luckham (London: Zed Books, 2003).

${ }^{186}$ Naomi Chazan and Deborah Pellow, Ghana: Coping with Uncertainty (Boulder, CO: Westview Press, 1986).
} 
The ruling-class faction in power took a favorable position on commercial farms early in the NRCQ̂ period of rule, as indicated above. However, customary ownership limited the availability of land for commercial farming, requiring state intervention in land allocation for private development. The NRC/SMC perceived as an opponent any chief in the traditional aristocracy who refused to cooperate with government. For instance, Lt. Col. Habada, of the NRC, called chiefs and individuals who engaged in ñfruitless litigationò over land, and who refused to release land to the government for farms, ñenemies of the revolution. ${ }^{187}$ The NRC deployed the military in targeted cases to intervene in land disputes between peasants and capitalist farmers. The NRCố intervention to support capitalists in rice farming in the northern part of Ghana is the bestknown example.

Investment in rice began in northern Ghana during the late 1960s, notably by former CPP ministers (investing the resources they had accumulated while in office), Yoruba traders from Nigeria, and civil servants, who tended toward smaller ventures. ${ }^{188}$ Chiefs or clan elders transferred p̃plotsò to investors without specific dimensions or papers, as had been the practice when land was tilled by hand and hoe by local residents. Disputes soon erupted between commercial rice farmers and local subjects demanding land access. The state did not intervene in these cases until the 1970s. The Lands Department exercised its power in the northern regions when commercial rice farming began under the $\mathrm{NRC/SMC}$, providing investors with documentation of land holdings to protect their investment in land. The military also offered services to commercial farms,

187 "Land Disputes," Daily Graphic, May 30, 1975, 3.

${ }^{188}$ Goody, "Rice-Burning and the Green Revolution in Northern Ghana." 
including land surveying and official documentation of land transfers and registration. ${ }^{189}$ The military also enforced written agreements in favor of the capitalist farmers, prompting the residents of one area to complain, ñYou came with the pen, now you come with the sword. o $^{190}$

Most coercive interventions in land disputes are not as well-documented as the rice case. In most cases, traditional stool subjects or subchiefs disputing land allocation or land revenue elevated the matter to destoolment. The NRC then deployed coercive bodies to enforce destoolments and enstoolments to ensure the survival of loyal chiefs. Subjects can remove traditional rulers in Ghana if they fail to follow customary rules of land allocation or if they do not account for stool revenue accruing from land transfers, though all destoolments had to be recognized by the state. Officials of the NRC became deeply entangled in chieftancy disputes that nearly always overlapped with disputes over land.

The NRC stated repeatedly that it would not tolerate chieftancy disputes, and, by extension, disputes over chieftancy caused by unpopular land allocations. ${ }^{191}$ It deployed the military to defend loyal chiefs such as the head of the frequently violent Ya-Na in northern Ghana. The NRC ordered sub-chiefs to pay allegiance to their favored Ya-Na, intervening in a dispute in Dagomba that has been one of Ghanâ̂ most notorious and violent chieftancy conflicts. The NRC threatened to remove any subchief who did not follow the Ya-Na recognized by the state, and it backed its position with force. ${ }^{192}$ The

\footnotetext{
189 Ibid.

${ }^{190}$ Ibid., 143.

191 "R.C.: Govt Won't Have Chieftancy Disputes," Daily Graphic, April 11, 1975, 3.

192 Iddrisu Seini, "Pay Allegiance to Ya-Na - Govt Orders Chiefs in Dagomba Areas," Daily Graphic, May 15, 1975, 1.; "Ya Na Replaces 7 Chiefs," Daily Graphic, April 30 1975, 16.; "Big Man Hunt," Daily
} 
police also defended chiefs across Ghana, particularly paramount chiefs under threat from subjects for colluding with state officials and their cronies. ${ }^{193}$

In the sections above, I argued that the NRC sought to secure its power through populism and patronage, providing state services to subaltern classes and incorporating loyal members of the traditional aristocracy into the patronage network. Moreover, the NRC rewarded loyal members of the same ruling-class faction, particularly military officers from Ghanâ̂ Armed Forces, with high-level, lucrative positions in the state,. Control over the state enabled the NRC to implement policies and provide finances to the dominant faction of the ruling class to accumulate wealth. Land provided a central means for the ruling-class faction in power to build its wealth. However, state coercion made the patronage strategy and wealth accumulation for the ruling-class faction possible. It provided a means for them to access agricultural and peri-urban land for development, and it allowed them to control contracts for land-based resources. Customarily, the traditional aristocracy held land in trust for its subjects, and subjects could remove members of the traditional aristocracy for the misallocation of land, including transfers to private holdings. The NRC used the police and military to prevent subjects from opposing land transfers and from removing unpopular chiefs who deviated from customary allocations. The NRC also deployed the military and the police to coerce chiefs to enforce land transfers. Finally, state coercion enabled the NRC to exclude other

Graphic, January 7, 1975, 16.; Iddrisu Seini, "R.C. Submits His Report on Dagomba Chiefs," Daily Graphic, May 15, 1975, 12.

${ }^{193}$ See for example: "Police Hunt for a Kumawu Chief," Daily Graphic, March 6, 1975, 1.; "Police Guard Chiefs Palace," Daily Graphic, January 4, 1975, 3 .; George Nakyene, "Inspector Pushed Boy from Bus Police," Daily Graphic, March 4, 1975, 1. 
ruling-class factions from benefitting from the resources. The NRC/SMC $\hat{Q}$ interference in land relations and by extension in chieftancy created tensions at the local level. Land and chieftancy disputes increased across the country. In the next section, I examine the nature of resistance to the NRC/SMCQ̂́ interference in local land allocation, and the repercussions of this resistence in the emerging land-sales market.

\section{Section 4. Forging a Violent Land Market: Resistance to Primitive}

\section{$\underline{\text { Accumulation in Land }}$}

How did other classes react to the NRC/SMCôs intervention in land? How did this shape the early land-sales market? Peasants became angry over the loss of access to land and waterways. They also perceived that revenues from land were not equitably distributed or beneficial to the local community. Resistance to commercial development through political intervention in local land allocation occurred throughout Ghana. The lack of statistics on land transfers, litigation and violence makes it difficult to assess the actual number of land disputes nationwide during the 1970s. However, coverage of disputes in state-owned newspapers suggests that they occurred commonly and in all regions, with most taking place over rural farmland and access to waterways. ${ }^{194}$ In addition, in 1977 the Chief Justice and members of the Ghana Bar Association

\footnotetext{
${ }^{194}$ I found evidence in the state-owned dailies of land disputes that included chiefs in Amasaman, Dixcove, Builsa, Mile 7 Accra-Nsawam, Agogo, Ablenpke (in Accra), Bubiashie (Accra), and Boamang. This is significant, as the state newspapers served as the mouthpiece of the government and were under constant pressure from the executiveôs office to avoid reports unfavorable to the government. State newspapers would have been expected to downplay the extent of the struggles over land, which lowered government legitimacy.
} 
highlighted a problem resulting from overloading courts with land litigation cases. ${ }^{195}$ All indicators suggest discord in land relations and resistance to change. This section looks at the nature of the resistance by the traditional aristocracy and peasants.

\section{The Traditional Aristocracy}

The traditional aristocracy, in general, opposed the position of the NRC on land, despite the NRCôs attempts to pacify chiefs through patronage. Control over land allocation gave chiefs power over subjects and provided revenue. In 1975, the National House of Chiefs spoke out against the governmentô handling of stool-land matters. The chiefs did not complain about the NRCôs interference in the ways in which land should be allocated or in the choice of people or organizations to which it was allocated, but they objected to the fixing of farmland lease prices by the state Lands Commission. ${ }^{196}$ Chiefs found the rate of 30 pesewas per acres far too low, suggesting instead three cedis per acre for cash crops and one-and-a-half cedis per acre for food crops. ${ }^{197}$ The National President of the House of Chiefs, the Asantehene, sent an official committee to see Acheampong over the matter. ${ }^{198}$ The chiefs, however, could not force the NRC either to award them higher payments or to allow them to participate in deciding lease rates.

The traditional authorities also had little recourse to collect payment for land acquired by the state through executive instrument. For example, in the peri-urban Accra

\footnotetext{
${ }^{195}$ GNA, "'Govt Must Take over All Lands'."

196"Consult Us on Stool Lands - Chiefs Declare in Kumasi," Daily Graphic, January 30, 1975, 1.

197 The exchange rate at the time was 1.15 cedis to 1 U.S. dollar.

198 "Consult Us on Stool Lands - Chiefs Declare in Kumasi," Daily Graphic. The Lands Commission set the rate to be paid to chiefs for farm leases at 30 pesewas/acre, and the House of Chiefs was seeking three cedis for cash crops and one-and-a-half cedis per acre for food crops. The exchange rate at the time was 1.15 cedis to 1 USD.
} 
area of Nungua, tensions grew over land acquired by the state for estate development. The local youth association demanded that the NRC/SMC provide compensation for the land. Members also insisted that the traditional authority account for any revenue received from the transfer. In 1976, the Council of Elders of Nungua appealed to the NRC to pay compensation for the land. It also objected to the NRCôs failure to allocate some of the homes in the new estates to local people, indicating that this had been part of the agreement for the land transfer.

For the dominant faction of the ruling class, however, land had become a central means for the accumulation of personal wealth. As such, the NRC deepened local tensions by largely disregarding appeals from chiefs over land issues. In Nungua, the NRC/SMC publicly suggested that some payments had been made. Lt. Jackson, the Commissioner for Works and Housing, replied to the Nungua Council of Elders that negotiations with the Nungua chiefs had already been completed. He then instructed the Council of Elders to investigate the basis upon which the State Housing Corporation had begun construction on Nungua land, to identify the government organizations operating on Nungua land, and only then to report to the government. ${ }^{199}$ However, the NRC failed to resolve the compensation issue with Nungua. Local grievances developed between the customary authority and subjects over payments that had been made, and the land dispute transformed into a chieftancy dispute. The NRC then intervened in the chieftancy matter and appointed a one-person ñcommitteeò to determine the entitled claimant to the Nungua

199 "Nungua Elders Appeal," Daily Graphic, February 11, 1976, 12. 
Mankralo position. ${ }^{200}$ This enabled the NRC to retain its loyal clients in the Nungua customary system. The turmoil over land at Nungua was repeated in cases across Ghana.

The traditional aristocracy failed to secure its customary right to control land through the stateâ courts. Courts tended to support the private interests of the dominant ruling-class faction. The police then enforced the court directives over land transfers. In one case, an Accra High Court issued a restraint against the customary owners, preventing them from entering lands now held by a private family. The family claimed to have purchased the plots legally in a developing, high-income peri-urban area, but the chiefs denied having sold the land. ${ }^{201}$ The courts became choked with such disputes over stool land, but they failed to resolve the majority of these cases. Members of the traditional aristocracy who cooperated with the NRCôs demands for land found themselves at odds with their subjects, whereas those who objected to the NRC $\hat{\mathbf{s}}$ directives faced the wrath of the state. In both cases, the incidence of land disputes soared.

\section{$\underline{\text { Subaltern Classes: Customary peasant subjects }}$}

Peasants and stool subjects objected to the actions of the traditional authorities and the NRC in land allocation. Peasants had no leverage over either chiefs or the state to secure their interests. Stool subjects organized in part through the establishment of youth groups. Youth associations formed often in relation to the customary stools; this happened, for example, in the peri-urban Accra areas of Nungua, La and James Town,

\footnotetext{
200 "Nungua Mankralo Affairs," Daily Graphic, December 30, 1976, 16.

201 "'No Entry' to Ga Mantse," Daily Graphic, December 13, 1976, 3.
} 
and in Builsa and other northern areas. The youth association in the Builsa area confronted the NRC and petitioned the state to demand changes to land and customary stool policy. The Builsa youth association hoped to set an example for other youth associations to follow that could lead to change in national land policy. ${ }^{202}$ But youth groups lacked the finances to organize into a national network to resist land transfers to private holdings and the misallocation of land and misappropriation of revenues.

In some areas, youth joined members of the traditional aristocracy who had been excluded from covert land payments to loyal chiefs, to demand that the state and other customary leaders account for payments. For instance, at Agogo, Kumawu and Kwamang, youth associations and some members of the traditional aristocracy requested a state probe into the disbursement of 1.3 million cedis that had supposedly been paid to the traditional area for land acquired by the Department of Game and Wildlife. ${ }^{203}$ It is not surprising that the NRC/SMC failed to rectify the issue, and local discord worsened.

Peasants had no legal mechanism by which to block land transfers to non-stool subjects. Stool and clan subjects could not take customary leaders to court under thencurrent laws that granted them immunity while they were in office. The NRC ignored petitions from youth associations for reform to land management and traditional authority. It refused to change laws carried over from the colonial period that denied traditional state subjects the legal right to review the accounts of traditional authorities and family heads.

\footnotetext{
${ }^{202}$ Piet Konings, The State and Rural Class Formation in Ghana: A Comparative Analysis (London, Boston, Melbourne, Henley: KPI Limited, 1986).

203 "Chiefs Back Youth," Daily Graphic, December 7, 1976, 1.
} 
Youth groups did attempt to remove chiefs and other traditional state authorities they perceived to be responsible for land transfers and misappropriation of revenues. Local stool subjects both threatened and enacted destoolments according to custom. The process of destoolment often included taking possession of a stool or skin, enabling police intervention on the basis of theft. The destoolments often became violent. In addition, the destoolments could not be enforced without official state recognition. The state also refused to gazette the alternative chiefs enstooled by subjects. This loss of control over local stool matters deepened resentment against the NRC/SMC.

Local populations objected particularly when local farmers lost land or access to rivers. Paramount chiefs ejected tenants when they transferred land then used by stool subjects. Violent ejections might make the news, as in the case of the ejection of tenant farmers by a paramount chief in the western region of Ghana. ${ }^{204}$ In other cases, local communities complained when new landholders prevented farmers and herders from using water sources. Moreover, allocation of land for private interests often contradicted the customary rights of allocation because state officials and cronies usually had no traditional ties to the local stool. In such cases, forced transfers created ethnic tensions between local subjects and ñstrangers.ò

In northern Ghana, where the NRC had promoted commercial farms growing rice, cotton and grain, clashes developed over the allocation of land for rice farming to nonstool subjects and the loss of access to that land by local peasants. The intervention of the military to enforce land transfers prevented conflicts from escalating and spreading, but it

204 "Paramount Chief in Court," Daily Graphic, March 6, 1975, 16. 
did not resolve them. Peasants turned to evasive forms of resistance, such as vandalism, damaging property and destroying harvesting equipment. The most widely publicized sabotage occurred in the north of Ghana, where peasants burned rice fields under the cover of night. ${ }^{205}$ The public found rice burning shocking, because destroying food contradicted the norms of the area and occurred amid food shortages.

Lack of organization and primitive weapons reduced violent resistance to periodic sabotage. One dispute on the northern edge of Accra typified land disputes nationwide. About 50 people armed with capguns, cutlasses and sticks engaged in conflict. The attackers looted and damaged properties of seven villages near Nsawam, and then raped local women. ${ }^{206}$ The police arrested some of the accused, and a Magistrateô Court remanded 21 people to custody. The threat of armed intervention by the police or military deterred most communities from such violent confrontations.

\section{Section 5. The Mounting Opposition and the End of the Generals}

Chazan argues that ñavenues for redress against breaches of elite responsibility became impassableo ${ }^{207}$ during the NRC/SMC period. This was the case for local land disputes. The traditional aristocracy had customarily acted as local arbitrators for disputes between subjects over land, marriage and debts. But, it could not intervene and resolve a conflict over land or land revenue once it engaged in disputes against customary subjects. In addition, the NRC/SMC created the National House of Chiefs to arbitrate differences

\footnotetext{
205 Goody, "Rice-Burning and the Green Revolution in Northern Ghana."

${ }^{206}$ George Nakyene, "21 Remanded in Custody," Daily Graphic, February 28, 1975, 1.

${ }^{207}$ Chazan, An Anatomy of Ghanaian Politics, 345.
} 
over customary succession or abuse of power by chiefs, but the institution lacked an effective means to enforce decisions. The dominant ruling-class faction also controlled the state institutions, such as the courts, and official recognition of chiefs, further limiting avenues of justice for peasants and aggrieved members of the traditional aristocracy. The lack of financial resources and the threat of military or police action prevented the peasants from mounting armed resistance to the state and loyalists among the traditional aristocracy. This minimized the potential for larger social violence over land. However, relations between the peasants and the NRC/SMCôs loyal clients, including commercial interests and the traditional aristocracy, continued to deteriorate. Opposition mounted across Ghana as living standards declined and more sectors of society felt the effects of exclusion.

\section{Growing Resistance}

The NRC strategy to retain power with patronage strained the capacity of the state. Cocoa prices reached record highs on the global market, but the NRC/SMC had pushed Ghana into an economic crisis. It had allowed extensive loss of state revenue through corruption, but it had also lavishly overspent state funds, purchasing items such as fighter jets, trucks, armored cars, and luxury cars and motorcycles for the Ghana Armed Forces, and of luxury cars for many civil and public servants. ${ }^{208}$ A brief summary of economic and human development indicators shows the depth of the crisis. ${ }^{209}$ Real

\footnotetext{
${ }^{208}$ Hutchful, "A Tale of Two Regimes."

${ }^{209}$ More statistical indicators may be found in Rothchild, "Military Regime Performance: An Appraisal of the Ghana Experience."
} 
GDP declined, but inflation rose more than 100 per cent annually ${ }^{210}$. Real export earnings fell 52 percent, domestic savings and investment dropped from 12 percent of GDP to near zero, and import volumes declined 33 percent between 1970 and 1983. Per capita GDP declined 20 percent between 1970 and 1980. ${ }^{211}$ The combined decline in exports of cocoa, timber and gold, coupled with high global oil prices, exacerbated the balance-ofpayment deficit. The state would collect a mere five percent of taxable gross domestic product in taxes by $1980 .^{212}$

The NRC/SMC sought to extend patronage rather than change strategy, despite the large budget shortfalls. The NRC/SMC printed even more money and distorted currency values. ${ }^{213}$ The NRC/SMC increased worker wages by 100 percent and increased the producer price of cocoa. It also extended political appointments for clients representing various civil society constituencies. The customary ruler of Labadi (an indigenous township of Accra), Nii Anyitei Kwakwranya, who had facilitated the transfer of customary property in Madina for the redemption village, surprised few when he accepted a state position. However, the Secretary General of the Trades Union Congress and the Catholic Archbishop both declined such positions. ${ }^{214}$ Various chiefs and regional leaders of the ruling-class faction in power demanded a greater share of the stateôs resources.

\footnotetext{
210 Ibid.

${ }^{211}$ Eboe Hutchful, Ghana's Adjustment Experience: The Paradox of Reform (Oxford: James Currey, 2002).

212 Hutchful, "Pulling Back from the Brink: Ghana's Experience."

213 Rothchild, "Military Regime Performance: An Appraisal of the Ghana Experience."

214 Collins and Hansen, "The Army, the State and the 'Rawlings Revolution' in Ghana."
} 
The policies of the NRC/SMC hastened the deterioration of the living conditions of the average person to an unacceptable low. Malnutrition, stunting and wasting increased. ${ }^{215}$ Consumers found few goods to purchase; shortages included such basics as cooking fuel. The local food index more than doubled, from 1027.2 in December 1976 to 2260.5 in December 1977, despite an increase in the food supply in the initial years of the NRC. ${ }^{216}$ State-owned utility companies frequently interrupted electricity and water supplies as the NRC/SMC failed to maintain critical national infrastructure. Many stateowned enterprises and institutions effectively ceased to operate. Ghanaians and expatriates with adequate resources fled. An estimated 14,000 teachers left Ghana over this period, exacerbating the crisis in educational institutions. ${ }^{217}$ The black market and corruption, locally described as ñkalabule: or ñkeep the lid shut,ò grew amid the extreme shortages. $^{218}$

In 1977, Gen. Acheampong publicly blamed Ghanấ crisis on sins foretold in the Bible and flew in evangelists to pray for rain and to conduct other religious ceremonies. He also offered a referendum proposing to ñshare powerò between the military, the police and civilians in a union government. The public perceived the proposal for union government as protection for senior military officers, and their outrage emboldened the opposition. ${ }^{219}$ The opposition coalesced under the Peopleâs Movement for Freedom and Justice, led by former CPP, PP and NLC leaders allied with other associations of

\footnotetext{
${ }^{215}$ K. Konadu-Agyemang, "The Best of Times and the Worst of Times: Structural Adjustment Programs and Uneven Development in Africa: The Case of Ghana," The Professional Geographer 52, no. 3 (2000).

216 The base figure of 100 dates from March 1963. Rothchild, "Military Regime Performance: An Appraisal of the Ghana Experience."

217 Jeffries, "Ghana: The Political Economy of Personal Rule."

218 The origin of the term is debated, but is thought to come from the Hausa language.

${ }^{219}$ Kandeh, Coups from Below: Armed Subalterns and State Power in West Africa.
} 
workers, students and professionals. The Bar Association publicly challenged the NRC/SMC and blamed the military for its poor economic performance. The National Union of Ghana Students (NUGS) organized marches. Massive strikes took place; strikers included the Ghana Medical Association, Association of Professional Bodies, and the Association of Engineers, Architects and Surveyors, as well as teachersôorganizations and others. ${ }^{220}$

The NRC/SMC responded by deploying the police. The police shot and killed an African exchange student as they attempted to break up a protest at the University of Ghana, Legon campus. The National Union of Ghana Students organized a march to the castle in Accra, but the police stopped the march before it could deliver a petition to the head of state. Through the NUGS, university students joined workers under the Trade Unions Congress to stage protests. The NRC/SMC attempted to undermine the leadership of the student and worker bodies through bribes and threats of force, but the police and the military finally disrupted public demonstrations. Eventually, the NRC/SMC closed the universities and sent students home.

The distribution of state positions to military officers failed to fend off threats from within the military itself. Gen. Acheampongố largess with the police had undermined the armed forcesôcohesion. The NRC/SMC attempted to mend relations and bolster the image of the police with a flurry of articles touting police success in maintaining law and order. Gen. Acheampong made a personal visit to meet the wives of

${ }^{220}$ Hansen, "The Army, the State and the 'Rawlings Revolution' in Ghana." 
the police, as well. ${ }^{221}$ Regardless, angry crowds of citizens sporadically attacked the police. ${ }^{222}$ In one case in 1976, the Eastern Region Commissioner had to offer police refuge from the local population; ${ }^{223}$ the area chief then offered an apology for the ñmisunderstandingò over prices between farmers and police at a market. ${ }^{224}$ Increasingly, the police service became unable to thwart regime opposition.

On July 5, 1978, Lt. General Fred Akuffo and Brig. Odartey Wellington led a palace coup and successfully removed Acheampong. The renamed SMC II initiated attempts to reverse the dire economic situation through new policies, demonetizing and replacing the cedi in March 1979. The new head of state, Gen. Akuffo, established commissions to investigate abuse of office by former public officials associated with Acheampong. However, the new policies offered no short-term relief, but merely revealed extensive corruption, the perception of which was reinforced by the lack of punitive actions in the wake of inquiry findings. Despite a two-month state-of-emergency declaration and concessions on a transition to civilian rule, the SMCôs control over society slipped.

Coercive Decline and the Failure to the Defend the Dominant Ruling Class Faction

The political interference in the coercive apparatus increasingly eroded the NRC/SMCQ̂́ security base and its ability to defend its rule through oppression. The

221 "Kutu Meets Police Wives," Daily Graphic, March 15, 1975, 1.

${ }^{222}$ See for example, "Angry Crowd Beat up Police Driver," Daily Graphic, February 18, 1975, 1.; "Policeman on the Run," Daily Graphic, May 16, 1975, 1.; L. Therson-Cofie, "State Attorney Blames Police as Amissah Probe Ends," Daily Graphic, February 18. 1975, 1, 3.

223 "Osei Saves the Police," Daily Graphic, November 17, 1976, 6-7.

224 "'We Are Sorry"," Daily Graphic, November 20. 1976, 6-7. 
intelligence sector weakened so much that the SMC had inadequate information on the activities of the opposition. ${ }^{225}$ The frequent turnovers in top command positions within the military, with transfers to state positions and state-operated enterprises, undermined command hierarchies. ${ }^{226}$ Tension mounted over unequal distribution of privilege within the armed forces. ${ }^{227}$ The use of public office to accumulate private wealth by military officers polarized senior and junior forces; discord grew in the junior military ranks. ${ }^{228}$

The NRC/SMC began to lose control over coercive institutions. Crime exploded, the cross-border trade in marijuana flourished, and the black market predominated. The state could no longer protect its borders. It could not monitor arms and ammunition effectively within the military; unidentified military personnel distributed weapons to insurgents, including vigilante groups outside of the state institutions. ${ }^{229}$ The coercive bodies could not maintain order. An estimated 80 strikes took place between August and November 1978 , and even the civil service stopped work. ${ }^{230}$ The inability to rely on outmanned security services led the NRC/SMC to mobilize private political thugs to try to repress opponents. Thugs broke up a meeting of the Association of Professional Bodies, for example, despite the presence of a police service that merely watched the fracas. ${ }^{231}$ The NRC/SMCôs attempts to consolidate its military base through patronage failed to secure the regimeôs power, as the capacity of the coercive institutions declined.

\footnotetext{
${ }^{225}$ Hutchful, "Pulling Back from the Brink: Ghana's Experience."

${ }^{226}$ Kandeh, Coups from Below: Armed Subalterns and State Power in West Africa.

${ }^{227}$ Jeffries, "Ghana: The Political Economy of Personal Rule."

${ }^{228}$ Hutchful, "Pulling Back from the Brink: Ghana's Experience."

${ }^{229}$ Chazan, An Anatomy of Ghanaian Politics: Managing Political Recession, 1969-1982.: 339.

${ }^{230}$ Chazan, Ghana: Coping with Uncertainty.

${ }^{231}$ Collins and Hansen, "The Army, the State and the 'Rawlings Revolution' in Ghana."
} 
The Junior Ranks and ñJunior Jesusò

It is not surprising that junior military officers organized a coup $4^{\text {th }}$ June, 1979, removing Gen. Akuffo; following the coup, SMCII. Flt. Lt. Jerry John Rawlings and the Armed Forces Revolutionary Council (AFRC) came to power, with Rawlings popularly heralded as the ñunior Jesus.ò The AFRC promised to oversee the election and transfer power to a civilian regime the same year. The AFRC focused its short rule on punishing corrupt politicians and their business allies based on the investigations initiated by Gen. Akuffo. The AFRC executed a number of high-ranking NRC/SMC officials and an unknown number of loyalists, including former Minister of Works and Housing Col. Kotei, for misappropriation and illegal acquisition of houses and properties. In addition, the AFRC confiscated assets of army officers engaged in various forms of corruption. For instance, it confiscated agro-businesses and farms that had smuggled produce outside of Ghana. ${ }^{232}$ The AFRC took additional measures to stop the loss of state revenue through corruption; it increased tax collection, repaid outstanding debts to state financial institutions, enforced price controls on consumer goods, and punished commodity hoarders. It also issued an order to shoot smugglers, including those illegally transporting cocoa, timber, rice, gold and diamonds across Ghanaôs borders.

The democratically elected Nkrumahist Peopleôs National Convention, under President Limann, held power for only a brief period. It had failed to stanch corruption and to implement policies to reverse Ghanâ̂ decline. The political and economic crises had continued to rage, including land disputes neglected by the AFRC and Limann

${ }^{232}$ Ibid. 
regimes. Flt. Lt. Rawlings returned to power through another coup on December 31, 1981, and established the Provisional National Defense Council (PNDC). The land conflicts would figure prominently in the strategy of the PNDC, but with a starkly different approach.

\section{$\underline{\text { Conclusion }}$}

This chapter concludes by returning to the questions posed in Chapter 1 to evaluate the relevance of the NRC/SMC period in the process of change in land relations. How did land relations change? Who benefited and who was excluded? What role did the state play in the change? And how did the period contribute to the emergence of a violent land market?

Land relations began to shift during this period toward greater alienation and declining access for customary subjects in areas that had not undergone commoditization during the cocoa boom of previous centuries. The change toward a land-sales market does not appear to be the result of the development a free land market or of some other ñaturalò or ñevolutionaryò movement in land relations. Global forces also seem to have played a limited role, as the period pre-dated structural adjustment in Ghana and massive foreign investment in land. Rather, the domestic ruling classố political strategy played a larger role. The NRC/SMC promoted policies for low-risk investment in real estate development and commercial agriculture to accumulate wealth through land and landbased resources. The policies became violent because the dominant ruling-class faction used control over the state to facilitate its own land accumulation and to exclude 
subaltern and other ruling-class factions, as well as the majority of the traditional aristocracy, from acquiring land.

The NRC/SMC deployed coercive institutions to enforce land transfers and defend its interests in land. The NRC/SMC used the police and military to intervene in land disputes between commercial farmers and local peasants, and between chiefs and their subjects who were loyal to the NRC. The use of coercion limited the resistance staged by subaltern classes, but tensions over land continued to escalate. Popular anger against the ruling classôs land-grabbing overlapped with growing opposition to the regime across Ghana. Land had become an unavoidable political issue by the time the AFRC overthrew the NRC/SMC in 1979.

The mobilization of all state institutions to defend the interests of the ruling-class faction in power and its loyal local patrons had constrained the ability of communities or factions to confront the perceived abuse of power, but tensions simmered. The faction of the ruling class in power under the NRC/SMC had, in order to secure its dominance, altered land relations, bent traditions and allowed the alienation of large tracts of prime real estate and farmland. Stool subjects and individual family members found their lands transferred, with titles outside their control and beyond their access. Customary areas had been left embroiled in disputes over succession lines to chieftancy and other traditional aristocracy positions, because of the interference in land allocations. By 1979, land relations had changed not according to the natural impetus of the market, but under the direction of the ruling- class faction in power, leaving politically charged local conflicts all around the country. 


\section{Chapter 4. New Political Strategies and a Counter-movement}

\section{in Land Relations: The PNDC Years}

“'Most of [the land guards] were having guns and were firing indiscriminately, they were not warning shots...Already we are in tension for what they did on Friday, we cannot sit down for them to come and destroy everything that we have, so we had to fight them...For the first time they came here, if they had come with an intention to [demarcate] the land we might have understood them, but they came and just started shooting, we cannot understand that,' a resident said. 'We suspect they have been given money to destroy us, we won't sit down for them to destroy us, ' another resident added. ",233

Land transfers from customary to private holdings in the peri-urban areas and rice-growing regions had created social tensions by the time the PNDC took over state power in the $31^{\text {st }}$ December 1981 coup. The NRC/SMC regime had co-opted and coerced the traditional aristocracy to transfer land to political clients and to acquire personal wealth. The NRC/SMC further supported land commoditization by political clients through access to finance from state-owned banks, the provision of state real estate development contracts, and loose enforcement of laws regulating trade, taxes and land ownership. Subaltern classes denied access to customary lands objected to the changes in land relations and state interference in land allocation. Subaltern classes also demanded that that customary leaders account for revenue received from land and land-based natural resources. The NRC/SMC used the state coercive apparatus to suppress protests

${ }^{233}$ Residents And Landguards Clash At Avenor, 2 Dead, Accessed November 16, 2009. http://news.peacefmonline.com/social/200911/31815.php. 
and to enforce land transfers and the authority of favored chiefs. The PNDC took over state power amid this tense and disputed process of change in land relations.

The PNDC became the new dominant faction of the ruling class, but built its early support in the base of the Nkrumahist faction. Nkrumahist and socialist associations such as the Kwame Nkrumah Revolutionary Guards, Peopleôs Revolutionary League, African Youth Command and the Social Democratic Front, June Fourth Movement (JFM), New Democratic Movement, Pan African Youth Movement, as well as workers and students, rallied public support for the PNDC. In addition, leading members of the PNDC associated with the old Convention Peopleô Party, notably Capt. (rtd.) Tsikata and Finance Minister Kwesi Botchwey. A few Danquah-Busia faction members also joined the PNDC, such as future president J. A. Kufuor, though most disassociated themselves with the government before the end of the 1980s. The PNDC did not claim to be Nkrumahist, but held clear links to that faction.

The PNDC also came with a different political strategy than the previous ruling faction. Early and persistent coup attempts made securing power the overriding political priority. The PNDC integrated its security objectives into the overall development plan, ${ }^{234}$ and elevated security to the highest level ever seen in a regimeôs political strategy in Ghana. ${ }^{235}$ The PNDC increased the capacity of security institutions and created new óevolutionaryôbodies that worked within the coercive apparatus. The óevolutionaryô institutions became a nation-wide vehicle to both suppress ruling class rivals and build an

\footnotetext{
${ }^{234}$ Hutchful, ñPulling Back from the Brink.ò; Zartman, I. William. ñGovernance as Conflict Management in West Africa,ò in I. William Zartman, ed., Governance as Conflict Management: Politics and Violence in West Africa. (Washington, D.C.: Brookings Institution Press, 1997).

${ }^{235}$ Eboe Hutchful, "Pulling Back from the Brink: Ghana's Experience."
} 
alternative support base among the peasants and urban poor. The PNDC also used the coercive apparatus to implement austere economic policy. The PNDC sought to reduce the use of state institutions as a means for ruling class accumulation. The Economic Recovery Program (ERP), in other words stabilization and structural adjustment policies, provided a tool to stifle accumulation by the rival ruling class faction that sought to finance coups and build an alternative client network.

Hutchful asserts that ñthe security sector was at the centre of [a] remarkable transformation..$^{236}$ Annual growth rates topped 5 per cent by the late 1980 s to early 1990s. ${ }^{237}$ Inflation declined from 122 per cent in 1983 to 10 per cent in $1992 .^{238}$

Government revenue rose to 14.4 per cent of GDP by $1986,{ }^{239}$ and Ghana recorded budget surpluses from 1986 to $1991 .^{240}$ The cocoa sector, still the mainstay of the economy, expanded 6.7 per cent annually, while agricultural output grew an annual 2.7 per cent. ${ }^{241}$ The PNDC also sought to expand the countryôs infrastructure: road, water and electricity improvement garnered 62 per cent of the budget between 1983 and $1986 .{ }^{242}$

The PNDCôs efforts to suppress rival ruling class factions and to gain support among the subaltern classes incorporated an alternative emphasis on land holdings and real estate properties. Section 1 below outlines this shift in strategy by the new dominant

\footnotetext{
236 Ibid., 85.

${ }^{237}$ M. Martin, ñNeither Phoenix Nor Icarus: Negotiating Economic Reform in Ghana and Zambia, 19831992,ò in Callaghy, T. and J. Ravenhill, eds., Hemmed In: Responses to Africa's Economic Decline (New York: Columbia University Press, 2003).

${ }^{238}$ M. Bawumia, ñUnderstanding the Rural-Urban Voting Patterns in the 1992 Ghanaian Presidential Election. A Closer Look at the Distributional Impact of Ghanaôs Structural Adjustment Programme,ò The Journal of Modern African Studies 36, no. 1(March 1998).

${ }^{239}$ Hutchful, ñPulling Back from the Brink.ò

${ }^{240}$ Bawumia, ñUnderstanding the Rural-Urban Voting Patterns.ò

241 Ibid.

${ }^{242}$ Konadu-Agyemang, ñThe Best of Times and the Worst of Times.ò
} 
faction of the ruling class. The new ruling faction in power strengthened the capacity of the state and enforced economic policies to suppress rivals. Section 1 also outlines the PNDCQ̂́ attempt to build an alternative political support base among peasants and the urban poor. The PNDCôs position on land played an important role in both suppressing rival factions and attracting subaltern support. Section 2 then examines the ruling class factionôs approach to the accumulation of wealth, noting the change in relationship between the government on one hand, and other ruling class factions and peasants on the other that stymied large-scale accumulation despite improvements to the economic indicators. The intended and unintended consequences of the PNDCôs strategy on land relations are discussed in Section 3. The chapter ends with an introduction to the PNDC $\hat{\mathbf{Q}}$ move toward the transition to democracy.

\section{Section 1. Means to Access and Maintain Power: Fusing the Political}

\section{and Coercive Strategies}

\section{Countering Threats to Power: the Factional Ruling Class}

Numerous coup attempts from the right-wing rival faction of the ruling class and radical left within the PNDC coincided with intense ideological debates over policy direction and approaches to governance. Members of the Ghana Armed Forces and the Ghana Police Service also posed potential threats to the PNDC. The PNDC reformed the security institutions and created ñrevolutionaryò bodies to address potential threats. As Nugent points out, the PNDC did not broadly apply repressive measures or arbitrary use 
of terror during its rule, but rather, tended to select individual opponents as targets for coercion or co-optation. $^{243}$

\section{Neutralising Internal Divisions}

Tension built within the PNDC soon after the December $31^{\text {st }}$ coup between the áecurocratsôand áechnocratsôon the one hand, and the óadical leftôon the other. ${ }^{244}$ The óadicalôelement was represented by PNDC members such as Chris Atim and AkataPore, leaders from groups formed following RawlingsôJune 4, 1979 coup, such as the Peopleâs Revolutionary League of Ghana and the June 4 Movement (JFM). The óadical leftôsought a árue revolutionary transformationôof Ghana through óevolutionary committeesôin which Ghanaians: ñn the towns and villages, on the farms, in the factories, mines, shop floors, everywhere ... debate national issues and take decisions affecting the lives of the ordinary people. . all the people will participate in taking vital decisions and in running the country. Oे $^{245}$ Flt. Lt. Rawlings, himself a member of the JFM, had called for the establishment of defense committees across the country in January 1982: Peopleôs Defense Committees (PDC) in communities, (WDC) Workers Defense Committees in factories, state-owned enterprises and other workplaces, and the Armed

\footnotetext{
243 Paul Nugent, Big Men, Small Boys and Politics in Ghana (Accra: Asempa Publishers, 1996), 178. 244 The apt term óecurocratôis used by Nugent, Big Men, Small Boys.

${ }^{245}$ Workers Banner, September 1981, June Fourth Movement, cited in:Zaya Yeebo, "Ghana: Defense Committees and the Class Struggle," Review of African Political Economy 32 (1985).
} 
Forces Defense Committees (AFDC) in the security services. ${ }^{246}$ All the defense committee reported to a National Defense Committee under the Chairman of the PNDC.

The óadical leftôbegan to complain in the first year after the 1981 coup that the regime was óeactionaryôand not truly revolutionary. Disputes centered on issues such as the role of the óevolutionary committeesôin the police and the armed forces, how revolutionary committees should be structured, and economic policy. ${ }^{247}$ The PNDC leaders ultimately clashed over the degree of autonomy and the objectives of the PDCs. Flt. Lt. Rawlings and his close advisors, including óecurocratôCapt. (rtd.) Tsikata, blamed the áevolutionary excessesôon the lack of control of the Interim National Coordinating Committee and on the PNDC member responsible for the PDCs, Chris Atim.. In addition, Rawlings and other óecurocratsô such as Brig. Quainoo, resisted a áanguardôrole for the Armed Forces Defense Committees in the military, insisting on enforcing command structures. Brig. Quainoo ordered that army PDCs follow command structure and act only with the consent of their unit commanders. ${ }^{248}$ The óadical leftôof the PNDC, which included Chris Atim and other young activists, objected to the demands of the ósecurocratsôand other senior leaders. They argued that the leaders were reactionary and sought to rein in the PDCs to prevent radical change.

Internal tensions peaked when PNDC technocrats, led by university professor and PNDC Secretary for Finance Kwesi Botchwey, turned to the World Bank and IMF for

\footnotetext{
${ }^{246}$ The model and actual founding dates for the defense committees is debated, as discussed in M. Oquaye, Politics in Ghana, 1982-1992: Rawlings, Revolution and Populist Democracy (New Dehli: Thompson Press Ltd., 2004). See also, Yeebo, ñGhana: Defense Committees and the Class Struggle.ò ${ }^{247}$ Yeebo, "Ghana: Defense Committees and the Class Struggle."

${ }^{248}$ Ibid.
} 
assistance after the Soviet Union refused to provide needed financial support to Ghana. ${ }^{249}$ The ñadical leftò, opposed the agreement with the financial institutions. They objected to the liberal economic policies and also to the position that the neoliberal institutions took on the leftist committees. The IMF and World Bank did not want the WDCs and PDCs to be regarded as state institutions and they rejected the extreme position the WDCs and PDCs had taken against private business in Ghana. ${ }^{250}$. The Finance Secretary announced the new policies in the April 1983 budget. The discord within the PNDC could no longer be contained.

Flt. Lt. Rawlings announced the change in the PNDC approach in a public speech in 1983:

We can no longer postpone the time for halting the populist nonsense and for consolidating the gains of the past 20 months and making a noticeable leap forward ... Production and efficiency must be our watchwords. Populist nonsense must give way to popular or unpopular sense . . to scientific sense, whether it is popular or not. $^{251}$

A number of radical left leaders participated in coup attempts in the first two years in power. Flt. Lt. Rawlings and his closest advisors dealt with the internal regime struggles by forcing resignations or removing opponents of neo-liberal reform from the PNDC executive. ${ }^{252}$ The PNDC dissolved the oversight committee for the PDCs, and

\footnotetext{
${ }^{249}$ The USSR advised Ghana to go these institutions. Martin, M. ñNeither Phoenix Nor Icarus.ò ${ }^{250}$ Adu Boahen, ñGhana: Conflict Reoriented,òin I. William Zartman, ed., Governance as Conflict Management: Politics and Violence in West Africa (Washington, D.C.: Brookings Institution Press, 1997); World Bank, Ghana - Policies and Program for Adjustment (Washington, D.C.: The World Bank, 1984). ${ }^{251}$ Untitled, West Africa, September 12, 1983.

${ }^{252}$ Martin, ñNeither Phoenix nor Icarus.ò
} 
arrested radical leaders, such as Yao Graham and Kwesi Pratt. Many of those who had constituted the radical left of the PNDC, including Chris Atim and Yao Graham, went into exile in European and North American countries.

The PNDC announced a legal framework in 1984 to institutionalize the defense committees ${ }^{253}$ to clarify the stateâs position on the role of the defense committees in governance. The PNDC renamed the bodies the Committees for the Defense of the Revolution (CDR) and re-structured their administration, explained in more detail below. State officials advised defense committees against malfeasance and unacceptable behavior, and the PNDC punished incidents of abuse of power by cadres. The CDR would play an important role in containing rival factions of the ruling class, but the PNDC first ensured that the óevolutionary committeesôdid not constitute a threat to its own rule.

\section{Reforming the Security Service: Countering Threats}

Not surprisingly, the military also posed a threat to power. Ghana had experienced several coups and more coup attempts from the military since 1966. The 1979 coup resulted in the execution and arrests of high-ranking officers. The PNDC strategy to contain the military threat, however, marked a shift from the NRC/SMC strategy of military patronage appointments. The PNDC regime did not appoint military officers to dominate the government or state-owned enterprises, instead naming civilians and only a

${ }^{253}$ Breda Atta-Quayson, ñNew Law on NDC in the Offing,ò People's Daily Graphic, February 25, 1984, 1 $\& 4 / 5$. 
few military officers to key positions. Countering the military threat required institutional reform.

The lower military ranks led the PNDC coup of 1981 amid áchaosôin the command structure and ethnic cleavages stemming from the NRC/SMC interference in the military. Flt. Lt. Rawlings had initially stated that the PNDC sought accountability starting with the armed forces and supported the AFDCs objectives to empower the ranks. The political activities of the AFDCs, however, undermined discipline and control. Flt. Lt. Rawlings and others, such as Brig. Quainoo and Gen. Nunoo-Mensah resisted attempts by the radical left of the PNDC to álemocratizeôthe armed forces under the revolutionary bodies. The PNDC used the transformation of the PDCs into the CDRs to de-link the administration of defense committees from the armed forces, de-radicalize the armed forces defense committees and impose greater government control. ${ }^{254}$ The PNDC limited the duties of the new Armed Forces Committees for the Defense of the Revolution (AFCDR) to actions that would improve the effectiveness of the unit and the conditions of service of all ranks. ${ }^{255}$ At the same time, the military purged and disbanded rebellious units.

The PNDC also introduced and restored key governance institutions within the armed forces and enforced command structures, following the Erskine Commissionôs report of 1988. The PNDC succeeded in subordinating the military to the control of a civilian minister. ${ }^{256}$ The PNDC also avoided promotion as a reward system and allowed

\footnotetext{
${ }^{254}$ Hutchful, ñPulling Back from the Brink.ò

${ }^{255}$ E. Hutchful, "Military Policy and Reform in Ghana," Journal of Modern African Studies 35 (1997).

256 Ibid.
} 
the top hierarchy to serve full terms, establishing order in the system of succession. The PNDC did allow junior officers to play an increased role. Security scholars generally agree that the PNDC restored the militaryô capacity, and improved its effectiveness in maintaining order, even throughout tough economic times. ${ }^{257}$

Moreover, the PNDC countered the coup threat by rebuilding the intelligence system that had collapsed after the 1981 coup, replacing the previous Special Branch of the military with the Bureau of National Investigation (BNI). The PNDC placed the BNI, officially, within the Police Service, but gave effective control to the Chief of National Security. The BNI transferred select operatives of the former Special Branch and instituted strict minimum recruitment standards. The revamped Secretariat of the National Security Council also ensured improved training and technology in intelligence gathering and analysis. ${ }^{258}$ The increased intelligence capacity proved effective. For example, the intelligence institutions uncovered an alleged coup plot against the PNDC by ómercenariesôin Brazil in 1986. ${ }^{259}$ Subsequent investigations uncovered arms aboard the ship Nobistor intended to support a coup attempt led by American mercenaries. The intelligence system arranged for the accused to be arrested in Brazil in May 1986. Intelligence bodies also uncovered an internal coup plot in September 1989 hatched by Major Courage Quarshigah and others within the Forces Reserve Battalion over condition of service grievances. ${ }^{260}$

\footnotetext{
${ }^{257}$ Hutchful, "Pulling Back from the Brink: Ghana's Experience."

${ }^{258}$ Hutchful, "Military Policy and Reform in Ghana."

259 Baffour Agyeman-Duah, "Ghana, 1982-1986: The Politics of the P.N.D.C.," The Journal of Modern African Studies 25, no. 4 (1987).

${ }^{260}$ Nugent, Big Men, Small Boys and Politics in Ghana.
} 
The PNDC upgraded the importance of border security and integrated border control into national security operations, largely to prevent the movement of arms across borders that could be used in a coup. In particular, Ghanaôs relations with bordering Togo deteriorated under the PNDC. Ghana periodically closed the border between the two countries, often under the guise of preventing the smuggling of consumer goods. However, the armed forces stopped alleged coup plotters organized by a Ghanaian Army captain in Togo from coming into Ghana in May $1986 .^{261}$

\section{Coercive Counter-Balance through 'Revolutionary' Forces}

The PNDC created institutions outside the pre-existing state structures to address coup plotters and potential centers of opposition. The PNDC created the new set of institutions ostensibly to increase accountability and staunch corruption. Flt. Lt. Rawlings blamed the economic and social crises on a lack of accountability and the corruption of state institutions under previous governments. ${ }^{262}$ The Committees for the Defense of the Revolution, one of the foremost institutions discussed above, constituted only one part of a national network of special security services. The new óevolutionary organsôcontained threats from the pre-existing security services, rival factions of the ruling class, and the traditional aristocracy.

The PNDC established the Forces Reserve Battalion, often referred to as the Commandos or the $64^{\text {th }}$ Battalion (a reference to the first Rawlings coup on June 4 ). The

\footnotetext{
261 Agyeman-Duah, "Ghana, 1982-1986: The Politics of the P.N.D.C.."

${ }^{262}$ Joseph R. A. Ayee, "A Decade of Accountability under Ghana's Provisional National Defence Council (P.N.D.C.) Government," Research Review 10, no. 1 and 2 (1994).
} 
$64^{\text {th }}$ provided an alternative force to the military comprised of soldiers, former policemen and civilians. The PNDC sent the Commandos for training in Soviet Bloc countries and Cuba. The $64^{\text {th }}$ operated largely outside the formal Army command, but occupied offices at the Burma Camp military barracks in Accra. The rival faction of the ruling class made numerous claims that the $64^{\text {th }}$ detained and tortured them at the Burma Camp office during the PNDC period.

The PNDC also created the Public Tribunals as an alternative to the existing courts to adjudicate crimes against the state in July 1982. The traditional courts at the time suffered from low credibility, because previous regimes had made controversial political appointments and allowed bureaucratic corruption. Public Tribunals operated at the local, regional and national level. The Public Tribunals provided the PNDC a means to quickly try attempted coup plotters. In 1983, a Public Tribunal convicted Kwame Pianim, a high-profile member of the rival ruling class faction, for allegedly plotting a coup, though he was not executed. ${ }^{263}$ A Public Tribunal also convicted seven coup plotters in June 1986, who were later executed. The PNDC used Public Tribunals in other cases, such as alleged corruption by lower ranked state officials and members of the Police Service. Legal professionals objected to Public Tribunals citing the lack of an appeals process, so the PNDC introduced an appeals process to neutralize the opposition.

The PNDC established óevolutionaryôorgans to specifically address economic fraud and corruption in different key sectors of the economy. All bodies, including the National Investigations Committee (NIC), Citizens Vetting Committee (CVC),

${ }^{263}$ Ibid. 
Committees for the Defense of the Revolution (CDR) and Civil Defense Organization $(\mathrm{CDO})^{264}$, as well as special tribunals, had investigative powers. These bodies reported to the Coordinatorô Office, which could also investigate corruption allegations. The National Investigation Committee and the Citizens Vetting Committee, investigated genuine cases of underinvoicing, illegal currency trading, fraudulent bank loans, unclaimed income, tax evasion, and other offences. These investigations, which were prosecuted under the Special Public Prosecutor, led to increased state revenue. However, they also investigated the finances and businesses of a number of former NRC/SMC and Busia ministers. ${ }^{265}$ Not surprisingly, the institutions stifled the rival ruling class factionô ability to accumulate resources, a subject I will discuss in greater detail below.

PNDC Law 1 (4) established the Citizens Vetting Committees, to ñ. . . investigate persons whose life styles and expenditures substantially exceeded their known or declared incomes and other related matters. $0^{266}$ The Citizens Vetting Committees attempted to identify and prosecute criminals at all levels, particularly targetting tax corruption and abuse of power by large-scale traders and professionals, such as lawyers. ${ }^{267}$ The PNDC formally redesignated the CVC as the Office of the Revenue Commissioners in 1984 as part of an overall reform of óevolutionary committees.ô

The PNDC set up the National Investigations Committee with PNDC Law 2 to investigate economic fraud and retrieve state revenue lost through official corruption. The

\footnotetext{
${ }^{264}$ Sometimes referred to as the peopleôs militias.

${ }^{265}$ For a discussion of four cases of rival political figures investigated during the PNDC period, see: Darko K. Opoku, "Political Dilemmas of Indigenous Capitalist Development in Africa: Ghana under the Provisional National Defence Council," Africa Today 55, no. 2 (2008).

${ }^{266}$ Republic of Ghana, 1982, cited in Ayee, "A Decade of Accountability under Ghana's Provisional National Defence Council (P.N.D.C.) Government," 66.

267 Ibid.
} 
NIC examined invoice irregularities, transfer pricing, and other forms of tax evasion, then turned over cases to the newly created Special Public Prosecutorô office for prosecution. The PNDC did not exclusively investigate businesses belonging to members of the rival ruling class faction, but examined the operations of multi-national businesses, state institutions, and customary authorities, among others. However, the PNDC did also confiscate businesses owned or managed by members of the previous government following evidence of economic fraud and tax evasion turned up by the NIC.

The CDRs provided the PNDC a means of monitoring both development and political activity in local villages and towns throughout Ghana. Local, district and regional Organizing Assistants reported through a chain of command to the national level. CDRs formally reported to National Security. The CDR coordinator held a cabinet level position in the PNDC and an office at the Castle (the seat of government). The PNDC also integrated the CDRs formally into the coercive apparatus, placing the district and regional level CDR Organizing Assistant on District and Regional Security Committee (REGSEC) respectively. CDRs also provided information to the intelligence services on perceived illegal and criminal economic activities, the status of potentially violent disputes, as well as threats to state security. The CDR structure enabled the PNDC to address specific political controversies and development issues in a more concerted manner across the country, and likely, to prevent factional opponents from building alternative centers of power outside the capital.

The CDRQ̂ armed wing, the Civil Defense Organizations, gave the PNDC a coercive presence in nearly every community, district and region. Members of CDRs 
could and did keep arms, as well. The district level administration was supposed to keep records of the arms issued, ${ }^{268}$ but such records are not publicly available yet. In one state newspaper article, the Regional Defense Committees appealed to the PNDC executive to train and arm 5000 cadres in each district, ${ }^{269}$ though this is unlikely to have been carried out. However, such public pronouncements by the CDR leadership contributed to the public image of the cadres as highly armed and trained, which contributed to containing coup threats from the traditional armed services.

\section{Constraining (and Reforming) the Police Service}

The Ghana Police Service itself presented a potential threat to state power. Police officials across Africa and more specifically, in Ghana had attempted coups. The PNDC sought to neutralize the threat from the police, but at the same time, to increase the capacity of the police to address the problems of rising crime and social insecurity that undermined PNDC legitimacy. The PNDC frequently criticized the actions of the police and warned the police not to be part of destabilizing the government. Flt. Lt. Rawlings accused the police of favoring the privileged with double standards of justice, and made it clear early in the PNDCô rule that the PNDC was scrutinizing its service. ${ }^{270}$ The IGP even went as far as to accuse the police of having dirty uniforms, tantamount to laziness. ${ }^{271}$

\footnotetext{
${ }^{268}$ Former PNDC member and leading cadre, personal communication, Accra, January 2007.

${ }^{269}$ GNA, ñSet Up More Militia Training Centres Now,òPeopleôs Daily Graphic, March 29, 1984, 6.

${ }^{270}$ Tetteh Quaynor, ñPolice Must Ensure Peace and Stability,ò People's Daily Graphic, March 31, 1984, 1 $\& 4 / 5$.

${ }^{271}$ S. S. Omane Inspector General of Police, ñSpeec,ò People's Daily Graphic, March 16, 1984, 3.
} 
Surprisingly, however, the PNDC made minor institutional reforms to the Police Service. It avoided privatizing the police services as had become the practice in countries undergoing structural adjustment, but it set the Tibiru Enquiry of 1986 to investigate irregularities in promotions and acceptance of non-qualified recruits, and removed or demoted persons found to have assumed positions by fraud. ${ }^{272}$ The PNDC ensured public media coverage of the trials and demotions, and introduced a new system of examinations for promoting police officers to prevent political interference experienced under prior regimes. ${ }^{273}$ Moreover, it attempted to implement promotion exams to halt nepotism and the hiring of unqualified policemen. Finally, the PNDC also required training seminars against corruption. $^{274}$

Members of the Police Service resisted implementation of the reforms. The PNDC identified Police Constables that attempted to sabotage the implementation of the new system, including blocking colleagues from taking required exams. The PNDC turned to the Police CDRs to assist in implementation of reforms. High level PNDC members met with the Regional Organizing Assistants of the Police CDRs to seek their assistance and physical protection was given to those willing to take exams. ${ }^{275} \mathrm{CDR}$ units acted to enforce Police compliance with regulations and laws. The CDRs identified

\footnotetext{
${ }^{272}$ Kwesi E.Aning, ñAn Overview of the Ghana Police Service,òJournal of Security Sector Management 4 , no. 2.

${ }^{273}$ Daily Graphic from 1989.

274 One such seminar was themed ñNew Policemen: The Man Who Cannot Be Bought,òin Breda AttaQuayson r̃Police Officers Urged to Be Alert,ò People's Daily Graphic, September 27, 1983, 1.; Adwoa Van Ess, ñTrigger Happy Policemen Must Change Profession,ò People's Daily Graphic, March 17, 1984, 4-5.

275 ñSaboteurs of Police Promotion Exams Warned,ò People's Daily Graphic, July 23, 1987, 8.; ñIGP Warns Vandals in Police Service,ò People's Daily Graphic, July 30, 1987, 1 \& 8-9; ñNinety Constables Sacked for Misconduct,ò People's Daily Graphic, August 8, 1987, 8.
} 
police (and military) personnel that participated in smuggling, unofficial confiscation of goods in the markets, and extortion and illegal roadblocks. ${ }^{276}$ Local Public Tribunals then tried and dismissed from the Police Service those policemen found guilty of such offenses.

Not surprisingly relations between the CDRs and the police were tense. Moreover, the Police Service continually clashed with local CDRs. The IGP called for cooperation between members of the two institutions, and attempted to reassure the police that the PDCs/ CDRs were meant to augment the role of the police and not usurp it. ${ }^{277}$ The PNDC, however, supported clearly the authority of the CDR.

Crimes under police jurisdiction declined during PNDCôs rule from the high levels of the 1970s. By 1986, murders had decreased to nearly half the 1980 rate, and robbery and theft both declined steadily between 1980 and $1991 .{ }^{278}$ Falling crime rates failed, however, to improve relations between the Police and the PNDC.

\section{Countering Local Power: The Traditional Aristocracy}

Not surprisingly, the PNDC treated the traditional aristocracy as a rival faction of the ruling class, particularly in the first few years in power. ${ }^{279}$ Powerful chiefs had aligned themselves with the rival ruling class faction as far back as the 1950s and many

\footnotetext{
${ }^{276}$ See: ñExpedite Action on Forcemen,ò People 's Daily Graphic, September 23, 1983, 1; Stephen Kofi Akordor ñDrivers, Police, Military Blamed for Smuggling,ò People's Daily Graphic, September 24, 1983, 1; GNA, ñPolicemen Warned,ò People's Daily Graphic, March 19, 1984, 1 \& 4-5.

277 ñIGP on Police, public co-operation, ò People's Daily Graphic, January 22, 1983, 4; Zenobia OforiDankwa, ñRegard PDCs as Partners Ï IGP,ò People's Daily Graphic, September 30, 1983, 1.

${ }^{278}$ Data from the Police Criminal Data Services Bureau, cited in: J. Appiahene-Gyamfi, ñAn Analysis of the Broad Crime Trends and Patterns in Ghana,ò Journal of Criminal Justice 30 (2003).

${ }^{279279}$ Kwame Boafo-Arthur, "Chieftancy and Politics in Ghana since 1982," West Africa Review 3, no. 1 (2001).
} 
had provided financial support to that faction from land and land-based resources. The PNDC decisively marginalized the chiefs in national affairs, though a small number of educated chiefs held technocratic positions in the national government. The PNDC also attempted to undermine chiefs in local society where they had the greatest influence. The PNDC denied the chiefs a formal, institutional role in government, terminating the requirement for chiefs on the local district councils mandated under the Danquah-Busian and Acheampong governments. The PNDC kept the ñchiefly classò, as Hansen denotes them, at armô length. ${ }^{280}$

The PNDC also attempted to reverse political interference in chieftancy succession that had contributed to violent conflicts throughout Ghana. The PNDC used the Local Government Bulletin to officially recognize the enstoolment or destoolment of chiefs nationwide, as done under prior governments. However, the Bulletin throughout the PNDC period reflects an unusual pattern in recognition and withdrawals of recognition. During the 1981 to 1984 period, one finds almost no notices of enstoolment, only destoolments backdated as early as 1969. It also restored recognition to chiefs in cases that had been decided by the courts in the 1960s but had been subject to political interference, such as the volatile and violent dispute over chieftancy in Bawku. ${ }^{281}$ The withdrawal of recognition by the PNDC enabled communities to install chiefs not affiliated with the rival faction of the ruling class that dominated the state under Busia

\footnotetext{
${ }^{280}$ E. Hansen, Ghana under Rawlings: Early Years (Lagos: Malthouse Press Limited, 1991). As cited in: Boafo-Arthur, "Chieftancy and Politics in Ghana since 1982."

281 "Bawku Chieftancy Affair," People's Daily Graphic, February 1 1984, 1 \& 8-9.
} 
and Acheampong. The Ministry of Local Government gradually gazetted recognitions of chiefs in later years.

The PNDC sought to prevent chiefs from participating in the local PNDC committees, and more pointedly, supported community action against the traditional aristocracy. The guidelines on Defense Committees banned the membership of chiefs, along with money-lenders and capitalist farmers. ${ }^{282}$ The óadical leftôof the PNDC warned chiefs not to use PDCs to consolidate their power and blamed chiefs for instigating óevolutionary excessôby PDCs. ${ }^{283}$ More generally, local Committees challenged the power of the customary authorities. Community-based CDRs investigated and arbitrated local disputes, usurping a role traditionally played by chiefs and customary authorities. CDR Cadres and chiefs particularly clashed over land allocation and land and natural resource revenues that provided the traditional aristocracy with financial power.

Boafo-Arthur argues that the most common form of conflict between chiefs and cadres during the PNDC period was the termination of royalty and land revenue payments. The PNDC recognized local Interim Committees that managed land revenues, some ớeturnedôby a chief to the community following CDR investigation and arbitration. In one example, the PNDC Western Regional Secretary set up a Peoplesô Emergency Development Fund in March 1982 into which all stool revenues from royalties paid on land, minerals, timber and other natural resources would be paid. ${ }^{284}$ In

\footnotetext{
${ }^{282}$ Yeebo, "Ghana: Defense Committees and the Class Struggle." The PNDC Secretary for the Central Region, himself a chief, instructed that chiefs could not form or dissolve PDCs. See: GNA, "Chiefs Can't Form P.D.C.S - Tanoh," People's Daily Graphic, March 14 1984, 1.

${ }^{283}$ Yeebo, "Ghana: Defense Committees and the Class Struggle."

${ }^{284}$ Hansen, Ghana under Rawlings: Early Years. Cited in: Boafo-Arthur, "Chieftancy and Politics in Ghana since 1982."
} 
another example, the PNDC instructed six chiefs of the Adansi area of Ashanti to pay back 84,450 cedis in stool land revenue not accounted for with the Lands Department and therefore, unlawfully collected. ${ }^{285}$ Investigations into the chieftancy disputes in Gonja resulted in orders to óefundômoney paid to the Traditional Council for the Mole game reserve, much of which had been used to buy expensive consumer goods for the paramount chief and to purchase weapons to defend his position. ${ }^{286}$ Many such cases suggest that the PNDC sought to weaken the traditional aristocracyô control over both land allocation rights and land and land-based resource revenues.

The extensive changes the PNDC had instituted created opposition. Austerity measures under stabilization and structural adjustment brought cuts in subsidies for health care, education and other social services, as well as the elimination of food price supports. Economic reform policies also brought massive civil service retrenchment. The PNDC had curtailed union protests and withheld support for workers who took over factories. The PNDCôs measures to neutralize the óadical leftôand contain the power of the traditional security services alienated pockets among its initial support base, particularly radical elements in organized labor, the Armed Forces and the Police Service. The threat of a coup was high.

The PNDC did not rely on personal patronage and populist spending programs to reduce those threats or counter the unpopularity created by its policies. The PNDC took a stiff position against corruption as a means to personal wealth, and combined that with

\footnotetext{
285 Albert Sam, "Six Chiefs Pay Back C 84,450.50 Stool Land Revenue," People's Daily Graphic, June 1 1983, 16.

${ }^{286}$ Yaw Boadu Ayeboafo, "Gonja Chiefs Had C 1,820,145 'Cola'," People's Daily Graphic, July $211983,1$.
} 
tight budget controls on spending by public officials. The PNDC instituted harsh penalties for abuse of official public resources, suspended holiday pay for civil servants and workers, and froze certain categories of recurrent expenditure. ${ }^{287}$ It also did not seek the support of the traditional aristocracy as a means to buttress its power. The PNDC treated the traditional aristocracy as a part of the ñogue capitalistòclass, making it impossible to build patron-client networks through chiefs. The PNDC also avoided the use of urban-biased public spending to regain favor. Traditional methods of patronage then, offered little promise. The PNDC responded to threats and opposition by strengthening the security services. The coercive capacity of the state increased despite a cut in overall defense expenditure, ${ }^{288}$ avoiding a security decline that scholars often associate with structural adjustment. ${ }^{289}$ In addition, the majority of Ghanaians at that time still lived in rural areas, and land relations provided the PNDC with one means of building a mass base.

\section{Building an Alternative Political Base: Political Strategy and Land Policy}

\section{Land Policy and Land Disputes}

The PNDC took a strong position on land that favored peasants over the traditional aristocracy. The PNDC promoted its position on land prominently in the stateowned daily newspapers, which provides evidence of the importance it placed on land

\footnotetext{
${ }^{287}$ Agyeman-Duah, "Ghana, 1982-1986: The Politics of the P.N.D.C.."

${ }^{288}$ Hutchful, ñPulling Back from the Brink.ò

${ }^{289}$ Chabal and Daloz, Africa Works.
} 
issues. ${ }^{290}$ The PNDC made state intervention in land disputes, the establishment of interim committees on land distribution, and confiscation of illegally acquired land frontpage news. The PNDC officially and publicly supported the actions of PDCs and CDRs in the creation of local Interim Management Committees on local land matters. In addition, it tasked the CVCs and NIC to scrutinize Ghanaians that owned multiple houses and large commercial farms. The PNDC further publicized the confiscation of lands and houses in áxecutiveôareas that had been acquired without title. ${ }^{291}$ Some PNDC supporters also formed a One Man-One House movement to further assert the PNDC position against capitalist land developers and óhylockôlandlords.

In February 1983, the PNDC began to reform institutions responsible for land management. It reconstituted the Lands Valuation Board and Lands Commission, appointed prominent professionals to state land institutions, and announced the creation of a new law on title registration. ${ }^{292}$ Officials also expressed concern over highly contentious issues subject to subaltern class support prior to the December $31^{\text {st }}$ coup, such as proper land use, issues of zoning in urban areas, and environmental protection in rural areas. The PNDC instituted a new land title registration law in 1986, following calls for tenure reform from CDRs and officials. The PNDC also established a special public tribunal for land disputes to decrease the thousands of cases in the traditional courts.

Some official pronouncements suggested possible radical reform to land management at the local level. One state official suggested the establishment of Land

\footnotetext{
${ }^{290}$ At the time, there was a shortage of news print and materials, so officials used the medium carefully to promote the most important issues.

291 ñGovt Explains its Position,ò People's Daily Graphic, February 18, 1983, 1.

292 ñSawyerr Heads Land Valuations Board,ò People's Daily Graphic, February 22, 1983, 1 \& 4-5.
} 
Distribution Committees that would include chiefs, elders and PDCs, visiting the disputeridden peri-Accra village of Nkwantanang. Other state officials repeated calls for community-based administrations to oversee the allocation and management of stool lands, even suggesting redistribution of revenues from land. ${ }^{293}$ Such changes threatened to reduce the power of the traditional aristocracy.

Alleviating major food shortages in the early 1980s offered the PNDC another means to gain support from subaltern classes and gain greater control over land. Ghana suffered from a declining food supply created by declining food prices, dwindling access to farm inputs, and deteriorating infrastructure under the NRC/SMC, compounded by a dought in 1983 and 1984. PNDC officials linked on-going land disputes to hindered food production, and used this as a justification for intervention in such disputes. ${ }^{294}$ The PNDC announced the state $\hat{Q}$ intention to ñdeal drasticallyò with those involved in litigation over farmland who threatened to jeopardize the food supply. ${ }^{295}$ The PNDC also insisted that all land under litigation by chiefs would be allocated to producers, so that cultivation of food would not be impeded. ${ }^{296}$ The PNDC further sided with farmers over chiefs and commercial farmers in pre-existing land disputes. ${ }^{297}$ The PNDC intervened on behalf of food and cocoa producing peasants in land matters, and pressured chiefs to release land to communities for farming.

${ }^{293}$ GNA, r̃Forson Suggests Land Committee,ò May 3, 1983, People's Daily Graphic, 8.

${ }^{294}$ Kate Hudson, ñSale of Farmlands by Rural Dwellers Perpetuating Poverty ï Yankson,ò People's Daily Graphic, January 25, 1989, 5: Statement made by Tema District Secretary to people of Adenta, Frafraha, Nmaidjor, Adjiriganor and other surrounding villages.

${ }^{295}$ See: Greater Accra Region dispute at Amasaman: Adwoa Van Ess, ñLitigations on Lands Wonâ Be Tolerated ï Quaynor-Mettle,ò People's Daily Graphic, February 4, 1984, 1 \& 4-5.

296 Yaw Boadu Ayeboafo, "Land Disputes Threaten Farming in Boamang Area," People's Daily Graphic, February 2, 1984, 1. Adwoa Van Ess, "Litigations on Lands Won't Be Tolerated - Quaynor-Mettle."

297 "'Help Avert Clash over Land Dispute'," People's Daily Graphic, February 10, 1984, 1. 
The PNDC directly linked the Defense Committees to efforts to institute óocial justiceôin land allocations and the food supply. In 1983, the Secretary of Defense Committees Yaw Akrasi-Sarpong ordered chiefs to allocate disputed lands to Peopleôs Defense Committees for farming, and warned that the state would confiscate lands from chiefs who refused to comply. ${ }^{298}$ PDCs joined with community youth associations to form communal farms to provide employment, a local source of food and income from trading. The transfer of disputed lands to communal farms helped to neutralize disputes between the youth and chiefs over land allocation, and gave the PDCs greater power at the local level. This created new tensions, now between the local Committees and the traditional aristocracy.

PNDC support emboldened PDCs and later the CDRs to investigate local land conflicts between the traditional aristocracy and subjects. PDCs publicly spoke against capitalist farmers and landlords, and what they argued were illegal land acquisitions and the imposition of chiefs by politicians. The PNDC recognized numerous Interim Management Committees (IMC) formed to oversee the allocation of land by PDCs and customary youth assocations. The IMCs identified discrepancies between land revenue reported to the Lands Department by members of the traditional aristocracy, and what was actually collected. IMCs directed chiefs to reimburse stool subjects for land revenue collected, with the coercive and legal support of the CDRs and the NIC.

The National Investigations Committee also investigated highly contentious land cases and reported results to the PNDC cabinet, particularly disputes over state

298 ñHand over disputed lands to local PDCs, ò People's Daily Graphic, February 15, 1983, 1. 
compensation for land and land-based resources transacted during previous regimes and cases involving armed violence. The NIC arrested, jailed and fined the President of Ghana Manufacturers Association and five others for alleged misappropriation of funds through false land compensation claims. ${ }^{299}$ In one extreme case, investigations revealed that the local aristocracy had used land revenues to acquire arms to defend a paramount chieftancy position assumed during an earlier Busia regime. ${ }^{300}$ The PNDCố policies and public pronouncements on land supported a shift of power away from the traditional aristocracy towards PNDC Committees and aligned subaltern groups at the local level.

\section{Land and land revenue allocation: eroding traditional aristocratic power}

The PNDC departed from the Danquah-Busia factionô approach to land, in which the ruling class aligned with the traditional aristocracy to allocate land and land-based resources to cronies. Rather, it sought to improve the position of peasants relative to chiefs in land relations, intervening particularly in areas where it could increase its own political support. The PNDC withdrew state recognition of certain chiefs and recognized the destoolments of others, backdating the changes across decades if necessary. This had implications for past land transfers, as only officially recognized chiefs could authorize land sales or allocations. A backdated destoolment or withdrawal of recognition effectively reversed land transfers signed by those chiefs while they claimed official authority. Stool subjects in alliance with the PNDC Committees demanded the return of

\footnotetext{
${ }^{299}$ Jon Kraus, "Capital, Power and Business Associations in the African Political Economy: A Tale of Two Countries, Ghana and Nigeria," Journal of Modern African Studies 40, no. 3 (2002).

${ }^{300}$ Yaw Boadu Ayeboafo, ñGonja Chiefs Had c1,820,145 ó́Colaôò People’s Daily Graphic, July 21, 1983, 1.
} 
lands transferred by those chiefs who now lacked official recognition. The Interim Management Committees on land established by the PDCs and recognized by the PNDC then re-allocated land according to objectives of the new chief or the stool subjects.

The PNDC granted stool and clan subjects greater power over the traditional aristocracy with the controversial óAccountabilityôLaw. The PNDC issued the draft of the Head of Family (Accountability) Law in July 1983 for public discussion, ${ }^{301}$ and the state ônvitedôcustomary leaders to comment. ${ }^{302}$ The PNDC formally instituted the Head of Family (Accountability) Law (PNDC Law 114) in 1985. The Head of Family (Accountability) Law created a mechanism through which Committees and customary subjects, peasants and youth associations could take legal action against chiefs. Formerly, chiefs could not be removed without the support of principal members of the family and could not be challenged by junior members or subjects. Law 114 changed the procedure so that any head of family or chief who was in possession, control or in custody of family property was accountable to the family for that property, and had to provide an inventory of all property. In addition, any member of the family who claimed an interest in any family property, regardless of value, could apply to the court to compel the family head or chief to account for and file an inventory of family property. The court could compel that head of family or chief to render the requested accounts and an inventory of the properties in his custody. The local Committees and customary subjects used Law 114 extensively.

\footnotetext{
${ }^{301}$ Kojo Sam, "Head of Family (Accountability) Law Draft Out," People's Daily Graphic, July $231983,1$. 302 "Chiefs' Views Welcome," People's Daily Graphic, September 30 1983, 8.
} 
Law 114 provided a legal means to give peasants greater power in land relations. Cadres from Arbitration and Complaints Department confirmed that Law 114 increased their power in the communities, particularly with regard to land. The author of one report on Law 114 claimed that chiefs and family heads feared the youth of their communities, because of the application of Law 114 by the youth and defense committees. ${ }^{303}$ Not surprisingly, family heads and chiefs largely opposed the law, believing it would adversely affect them by undermining their control over subjects and enable the government to secure the allegiance of the individual directly and not through a patronage network organized by chiefs. ${ }^{304}$ The PNDC, however, did not respond to the objections of the traditional aristocracy, and continued to enforce Law 114.

\section{The Subaltern Rural Peasant: Promoting Small-holder Agriculture}

The PNDC focused policies and programs on rural areas more than any previous regime, in both land interventions and in agriculture. A main objective under the national Economic Recovery Plan was increasing food production. ${ }^{305}$ In the early 1980s, roughly seventy per cent of Ghanâ̂ population lived in rural areas, with twenty-four per cent of the overall active work force employed by the cocoa industry. ${ }^{306}$ The PNDC sought to mobilize rural support to capitalize on the disenfranchisement of rural producers, which had occurred significantly under the NRC/SMC Mikell argues that peasants had become

\footnotetext{
${ }^{303}$ S. Cudjoe, attorney and former cadre, Accra, July 2007.

${ }^{304}$ Cudjoe, ñThe Effects of Head of Family Law.ò

${ }^{305}$ Information Services Department, Ghana: Two years of transformation: 1983-84. (Accra: Government of Ghana. Undated).

306 Agyeman-Duah, "Ghana, 1982-1986: The Politics of the P.N.D.C."
} 
more aware of their position relative to other classes during the 1970 s, when farmers suffered from low producer prices for cocoa amid high world market cocoa prices; rumors filtered down to peasants of the ruling classôs opulent lifestyles. ${ }^{307}$ Global cocoa prices had remained high through the 1970s, but the NRC/SMC paid low farm-gate prices to extract as much tax on the cocoa as possible. Depressed farm incomes meant that cocoa farmers failed to replace plants affected by disease, and also neglected the use of other farm inputs, reducing production. In addition, NRC/SMC neglect of rural roads and rail lines impeded the movement of food and export commodities to markets and ports, and inputs to farms, furthering depressing rural livelihoods. The rice growing areas avoided much of the infrastructural deterioration, as members of the NRC/SMC had invested in commercial rice farms. A drought in the 1983-84 growing season added to the overall crisis in agriculture.

Flt. Lt. Rawlings and PNDC officials promised to revive the cocoa sector and secure the food supply. The PNDC mobilized farm industry labor, provided farm inputs and improved the rural infrastructure. óMobisquadsô communal labor groups based on the customary work group system, provided labor and organized rural producers throughout Ghana. Flt. Lt. Rawlings prompted students enrolled in higher education institutions to voluntarily bring cocoa and other crops to the ports. In addition, the PNDC offered soft loans and production inputs for the cocoa producers, including statesponsored spraying and new cocoa tree shoots. It also invested in local production of farm implements and improving seeds and fertilizers. The PNDC also increased farmgate

\footnotetext{
${ }^{307}$ Gwendolyn Mikell, "Peasant Politicisation and Economic Recuperation in Ghana: Local and National Dilemmas," The Journal of Modern African Studies 27, no. 3 (1989).
} 
producer prices for cocoa, which was a critical move to gain support amid national budget difficulties. The PNDC concentrated early efforts to gain rural support from cocoa and domestic food crop producers, but expanded its support to aquaculture, pineapple, and cola nut export in the mid- to late-1980s.

The PNDC also sought to build rural support through increased public investment in infrastructure. It noted the deterioration of the road system and related high cost of transportation as the primary causes of high food prices. ${ }^{308}$ The PNDC invested heavily in infrastructure that could assist farmers to get produce to market areas, in the cocoa growing regions as well as regions previously omitted from national road development. In particular, roads in the three northern regions and in the northern part of the Volta Region all improved. The PNDC also built infrastructure to support the transportation of goods on the Volta Lake and other waterways. These improvements enabled producers to increase their income and move goods to regional markets. The expansion of electricity also proved popular in villages and towns; electricity enabled rural communities to have street lights, drinking bars and frozen foods, along with refridgerated medicines. Flt. Lt. Rawlings often commissioned the projects personally.

Along the coast, the PNDC also supported fishing. It supported artisanal fishermen, largely canoe fishermen with outboard motors, spare parts, fishing nets and fuel facilities. To supplement sea fishing, the PNDC also encouraged fish farming with assistance programs to establish commercial and homestead fish ponds. According to its

\footnotetext{
${ }^{308}$ Information Services Department, Ghana: Two years of transformation: 1983-84.
} 
own data, fish harvesting increased $15 \%$ in the first year. The tuna catch increased from 18,300 metric tons in 1981 , to approximately 21,000 metric tons in $1982 .^{309}$

At the same time as it implemented programs in agriculture and rural infrastructure, the PNDC had local revolutionary committees promote its ósocial justiceô and áccountabilityôagenda in rural areas. CDR cadres disseminated state propaganda and information provided by higher levels of the administration to the communities. In addition, the CDRs underwent training in political mobilization and ideology. They promoted awareness of the status of peasants vis a vis other social groups. Poor, subsistence peasants, in turn, r̃hoped that the [PNDC] regime would intervene on their behalf and joined the PDCs for this purpose. $0^{310}$ PNDC officials, including Flt. Lt. Rawlings, publicly contributed to local, communal labor projects, and avoided the ostentatious displays of wealth associated with the NRC period.

The rural producers and small entrepreneurs responded positively to the PNDC agriculture and infrastructure programs. Production of cocoa rose from 150,000 tons in 1983 to 210,000 tons in $1986 .^{311}$ Maize output grew from 172,000 tons in 1983 to 411,000 tones in 1985. Rice production more than doubled between 1983 and 1985, from 40,000 to 90,000 tons. Plantain output increased from 342,000 tons in 1983 to 672,000 tons in 1985. Palm oil production increased such that it became a new export commodity. The strategy to build a support base among rural producers paid off. Peasant farmers

\footnotetext{
309 Ibid.

${ }^{310}$ Yeebo, ñGhana: Defense Committees and the Class Struggle,ò 69. Yeebo also argues that ómiddle peasantsôoccasionally joined PDCs, hoping and sometimes succeeding in getting PDCs to intervene in land disputes to their favour, undermining support for PDCs among peasants.

${ }^{311}$ Agyeman-Duah, "Ghana, 1982-1986: The Politics of the P.N.D.C.."
} 
perceived the policies in agriculture to be successful and the popularity of the PNDC and Rawlings grew in rural areas. ${ }^{312}$ The increased the income of and support services to rural producers also decreased the power of the traditional aristocracy.

\section{Secure Housing, the Urban Poor and 'Shylock' Landlords}

The PNDC paired its efforts to build peasant support in rural areas with a similar strategy for the urban poor. Interviews by Jeffries in 1990 suggested support from the urban poor for the PNDC, a surprising outcome given the adverse effects of structural adjustment on urban households. ${ }^{313}$ Indeed, the PNDC did appear to lose the support of labor and students following the introduction of austerity policies, including withdrawal of food price supports and massive retrenchment. However, the PNDC reached out to the urban poor through housing security. Rent constituted a pressing urban concern: 83.7 per cent of those living in the capital city rented accommodation and Ghanaôs rental housing costs exceeded that of other African urban areas. ${ }^{314}$ The number of disputes between landlords and renters ballooned during the NRC/SMC years, with rapid urban migration, an expansion of new rentals, housing shortages and economic crisis. Records from CDR

\footnotetext{
${ }^{312}$ Mikell, "Peasant Politicisation and Economic Recuperation in Ghana: Local and National Dilemmas." Scholars such as Richard Jeffries also attribute the success of Rawlings in the 1992 election to these policies.

${ }^{313}$ Richard Jeffries, "Urban Popular Attitudes Towards the Economic Recovery Programme and the P.N.D.C. Government in Ghana," African Affairs 91, no. 363 (1992).

${ }^{314}$ Kwadwo Konadu-Agyemang, "A Survey of Housing Conditions and Characteristics in Accra, an African City," Habitat International 25, no. 1 (2001).
} 
offices and interviews with cadres show that rent disputes constituted a major issue for the CDR Arbitration and Complaints Department. ${ }^{315}$

The PNDC sought an unprecedented level of intervention in private sector rentals at lower levels. ${ }^{316}$ The PNDC set the tone for the stateô intervention in housing in 1983. PNDC Law 42 provided a ñbasis of social justice and equality of opportunity ... particular attention being paid to the deprived sections of the community. ${ }^{317}$ PNDC Law 5 (Rent Control) followed upon that social aim by reducing to fifty per cent all rents payable as of December 31, 1981 below 1000 cedis. The Law stipulated an amount of 20 cedis for single rooms and 50 cedis for áchamber and hallôfor newly constructed dwellings, regardless of materials, far below the amount required for a landlord to recover building costs at the time. ${ }^{318}$ Law 5 allowed for the confiscation by the state of any premises in which a landlord contravened the law.

PNDC Law 7 (Compulsory Letting of Unoccupied Rooms and Houses) called for further intervention. The PNDC mandated that all unoccupied rooms and houses would be identified and let to those without places to live. Section 2 of PNDC Law 7 gave the PDCs and Local Rent Control Units (RCU) the power to forcibly enter premises to carry out the provisions of the law. The PDC and RCU had the power to negotiate a suitable

\footnotetext{
${ }^{315}$ Former cadres of the CDRs in the Greater Accra region, various communications, Accra, 2006 and 2007.

${ }^{316}$ For a discussion of the history of state intervention in rent agreements, see: K. Oteng Kufuor, "Private Sector Housing in Ghana: Some of the Legal Aspects of State Control since 1982," Journal of African Law 37, no. 1 (1993).

${ }^{317}$ PNDC Law 42, as quoted in Oteng Kufuor, ñPrivate Sector Housing in Ghana.ò

${ }^{318}$ Konadu-Agyemang calculated that it would take 416 years for a landlord to recover the 500,000 cedis required to build a 3 bedroom house at that time. See: Konadu-Agyemang, "A Survey of Housing Conditions and Characteristics in Accra, an African City."
} 
rent with the landlord and tenant, and to rent out any room or house to a tenant if a landlord would not agree to a suitable rent.

The PNDC moderated its position on housing in 1986 as it deepened economic reform, though it continued to advance the interests of tenants over landlords. ${ }^{319}$ PNDC Law 138 established Rent and Housing Committees in each city and town to be composed of a government representative nominated by the local CDR office, a landlord and two others appointed by the District Council. The RHC had the power to set rental rates, but based on new guidelines that accounted for rateable value of the premises, value of the land, current rate of overdraft interest, and landlord, tenant and other interested party obligations. In addition, the stipulated rents considered size and construction materials, though the rates would mean that it could take around 100 years for a landlord to recover building costs. ${ }^{320}$ Law 138 also outlined acceptable means by which the landlord could collect the rent. The new law further blocked landlords from raising rents prescribed under the law until 6 March 1987. PNDC Law 163 amended Law 138, giving the RHC only the power to enter and inspect a residential premise specified under Law 163. Law 163 did not provide the rent setting procedures, except to note that the proceedings should be public and guided by the rules of ónatural justice.ôLaw 138 and 163 lowered the punishment to fines and imprisonment, ending the provision of confiscation. Public Tribunals took over legal enforcement of rental laws. This represented a minor shift toward protecting the landlord, while still aiding renters.

\footnotetext{
${ }^{319}$ For an overview, see: Ninsin, Kwame A. ñNotes on Landlord-tenant Relations in Ghana since 1982.0 Research Review NS 5, no. 1 (1989).

${ }^{320}$ Konadu-Agyemang, "A Survey of Housing Conditions and Characteristics in Accra, an African City."
} 
The PNDC Committees became the means to enforce the PNDCôs rent decrees and to arbitrate disputes between tenants and landlords ${ }^{321}$ over rent payments, confiscation of property by both renters and leasors, and evictions. The CDRs underwent training in land, zoning, and rental laws, and often enforced the legal rights of tenants over landlords and ensured that landlords honored rent amount or lease terms agreements. The PNDC subordinated the interests of landlords to that of peasants and the urban poor. The PNDCô laws, according to housing experts, effectively provided a housing subsidy paid for by the landlord, and redistributed income from landlords to peasants. ${ }^{322}$ The rival faction of the ruling class responded that the rental laws violated the right to private property.

The measures that countered the interests of landlords and sought ósocial justiceô for tenants acted as a deterrent to land speculation and building estates for rentals. The PNDCQ̂́ scrutiny of land allocation by the traditional aristocracy, assistance to local communities demanding accountability on land allocation and revenue, and enforcing the rights of tenants over landlords favored subaltern classes, and contributed to a change in land relations from the NRC period. Land speculation by the ruling class that had become common during the rush for land in the 1970s slowed nearly to a halt.

\section{Section 2. Means of Accumulation: Tackling Domestic Political}

\section{Challenges and Defending Structural Adjustment}

\footnotetext{
${ }^{321}$ Ayee, "A Decade of Accountability under Ghana's Provisional National Defence Council (P.N.D.C.) Government."

322 Konadu-Agyemang, "A Survey of Housing Conditions and Characteristics in Accra, an African City."
} 
Early persistent coup attempts did raise the importance of the security sector in the PNDCô political strategy, but the reversing the inherited economic decline also became critical to securing power. The PNDCô Economic Recovery Programme emphasized economic stability, balancing the budget through increased state revenue and decreased state spending, and controlling inflation. The PNDC nested its political strategy within the ERP, seeking to stave off the rival ruling class faction and stabilize the economy simultaneously. Structural adjustment policies, increased collection of tax revenues and eliminating official corruption all contributed to shrinking wealth accumulation by the rival ruling class. The PNDCôs efforts to stave off the rival ruling class faction through financial blockages included undermining the traditional aristocracyôs control over land and natural resources.

Preventing Accumulation: Opposing Factions

\section{Private Business of the Rival Ruling Class Faction}

Kraus states that the policies of the PNDC attacked a ñong tradition of capital accumulation by the Akan ... through cocoa, trade, transport and urban housing..$^{323}$ This ethnicizes what was a general trend among a rising ruling class along Ghanaôs coast; many Ga families had accumulated wealth through the same means as the Akans ${ }^{324}$ and felt subject to the same attacks as the Akans. Kraus notes a widespread antagonism

\footnotetext{
${ }^{323}$ Kraus, "Capital, Power and Business Associations in the African Political Economy: A Tale of Two Countries, Ghana and Nigeria."

${ }^{324}$ For a history of the rise of the Ga ruling class, see: John Parker, Making the Town: Ga State and Society in Early Colonial Accra (Portmouth, NH: Heinemann, 2003).
} 
toward indigenous and multi-national corporations under the PNDC and an antipathy to the idea of capital accumulation.

PNDC actions in 1982 and 1983 besieged the ruling class, regardless of nationality or political affiliation. Two national PNDC policies reduced ruling class wealth significantly in 1982 . The PNDC instructed the public to turn in all 50 Cedi notes to banks, and then confiscated (and destroyed) the money. Then, it froze bank accounts with balances over 50,000 cedis. Most early attacks on óneo-imperialist capitalists,ô however, lacked national coordination. One radical left leader stated that the PNDC encouraged the PDCs to be spontaneous in their operations ${ }^{325}$ after the 1981 coup. Military personnel and the PDCs and WDCs sought to make goods available for the ñexploited massesò, so seized goods from retailers and wholesalers and resold them at low prices; many retailers moved into bordering Togo. ${ }^{326}$ One WDC, led by radical left PNDC activist, organized the worker takeover of Ghana Textile Printing Co., owned by United Africa Company. The PDCs and WDCs led worker takeovers of private firms and harassed business owners at the local level, as well. ${ }^{327}$ The CVCs took a census of the ownership of houses, offices and warehouses and kept a record of those who travelled by air (a sign of wealth). ${ }^{328}$ Committees investigated those assessed to be living at a higher status than justified by their immediate income, and punished those who could not provide evidence for a legal source of wealth.

\footnotetext{
325 Yeebo, "Ghana: Defense Committees and the Class Struggle."

${ }^{326}$ Kraus, "Capital, Power and Business Associations in the African Political Economy: A Tale of Two Countries, Ghana and Nigeria."

327 World Bank, "Ghana - Policies and Program for Adjustment."

328 Ayee, "A Decade of Accountability under Ghana's Provisional National Defence Council (P.N.D.C.) Government."
} 
The PNDC moderated its approach to containing the rival faction with the introduction of stabilization and structural adjustment. A prominent member of the PNDC is quoted as saying: $\tilde{n}$. . . if you want to be a millionaire in Ghana under any regime whatsoever, you can be a millionaire, as long as you are meeting your tax and rates obligations. ${ }^{329}$ However, weak state economic institutions hindered broad tax enforcement. The NRC/SMCôs had emaciated the revenue collection institutions in the 1970s. In addition, the majority of financial transactions, as much as 95\%, remained outside the formal banking sector and regulatory reach. The PNDC, therefore, assigned tax and financial regulation enforcement to the revolutionary bodies.

PNDC Committees concentrated revenue collection efforts, in many cases, on the rival faction of the ruling class. The NIC and CVCs froze bank accounts of individuals suspected of tax avoidance ${ }^{330}$, and then investigated their businesses. B.A. Mensah, who was linked to the NRC/SMC regime, lost ownership of International Tobacco Ghana following an investigation into unpaid tax arrears and other violations. ${ }^{331}$ The PNDC sold the company to Rothmanns to cover outstanding tax debts. Nationally, investigations into tax evasion ultimately increased tax revenue 500\% between 1982 and 1985. The PNDC also succeeded in creating the semi-autonomous Internal Revenue Service to replace the largely defunct Central Revenue Department. ${ }^{332}$ However, the rival political faction

\footnotetext{
329 "Towards Accountability," West Africa, July 4 1988. Cited in: Nugent, Big Men, Small Boys and Politics in Ghana.

${ }^{330}$ Kraus, "Capital, Power and Business Associations in the African Political Economy: A Tale of Two Countries, Ghana and Nigeria."

${ }^{331}$ Darko Poku, "Political Dilemmas of Indigenous Capitalist Development in Africa: Ghana under the Provisional National Defence Council," Africa Today 55, no. 2 (2008).

332 Ayee, "A Decade of Accountability under Ghana's Provisional National Defence Council (P.N.D.C.) Government."
} 
continued to claim that the NIC targeted them, despite numerous substantiated fraud cases.

The Committees also examined the ónon-performing assetsôstemming primarily from unpaid loans from state-owned banks given out during the NRC/SMC period. These investigations led to the confiscation of assets to repay loans. For instance, the NIC investigated Industrial Chemicals Ltd. owned by K. Safo-Adu, a minister under the Busia government, for tax evasion and diverting a loan secured by state-owned National Investment Bank. A Public Tribunal eventually acquitted Safo-Adu, but the factory had been closed for two years and the loan returned to the World Bank. ${ }^{333}$ In some cases, the NIC turned over cases to a Non-Performing Assets Committee, because no assets existed to cover the unpaid loans from the state-owned banks.

The process and transparency of investigations varied. The business community accused the CVCs and CDRs of taking arbitrary action without regard to due process. Those who had been members of previous governments or had ties to the rival faction of the ruling class felt particularly targeted. The business community that had relied on ties to state officials to access credit through state-owned banks and to increase its profits through avoiding prosecution for tax avoidance found the PNDCôs actions excessive. Many in the opposition ruling class faction felt that political motives drove confiscations, including factories and property, to repay loans to state-owned financial institutions and

\footnotetext{
${ }^{333}$ Poku, "Political Dilemmas of Indigenous Capitalist Development in Africa: Ghana under the Provisional National Defence Council."
} 
to pay tax arrears.. Former óadical leftôleaders claimed that Flt. Lt. Rawlings blocked investigations into PNDC members suspected of corruption. ${ }^{334}$

The PNDC also used rhetoric to undermine its rival faction in the ruling class. The PNDC Secretary for Finance and Economic Planning accused capitalists of ónfluence peddlingô profiteering and corruption. ${ }^{335}$ Flt. Lt. Rawlings referred to the businessmen engaged in illegal financial operations, including many that had operated during previous regimes, as óoguesôand áhiefsô The PNDCQ̂ official Programme for Reconstruction and Development in 1982 noted that support for local enterprise would be only for ñwellintentioned businessmen and investors. o $^{336}$ As one company executive noted, ก̃The morality of the profit motive is not as acceptable to Government as it should be..$^{337}$

The PNDC further restricted business and government communications. Tangri noted few or no mechanisms for private business interests to communicate with central government. ${ }^{338}$ Business associations had little information from the state, and limited or no access to state officials making economic policy. The Ghana National Chamber of Commerce and Association of Ghana Industries became largely inactive during the period. ${ }^{339}$ The AGI President had been a minister under a prior Busia faction government, and had even been arrested by the PNDC for alleged illegal business practices. The rival faction of the ruling class also argued that the PNDC dominated the divestiture process

\footnotetext{
334 Ibid.

335 Tangri, "The Politics of Government-Business Relations in Ghana."

${ }^{336}$ Government of Ghana, Programme for Reconstruction and Development, (Accra: Government of Ghana, 1982).

337 Ayee, "A Decade of Accountability under Ghana's Provisional National Defence Council (P.N.D.C.) Government."; Tangri, "The Politics of Government-Business Relations in Ghana," 100.

338 Tangri, "The Politics of Government-Business Relations in Ghana."

${ }^{339}$ Kraus, "Capital, Power and Business Associations in the African Political Economy: A Tale of Two Countries, Ghana and Nigeria."
} 
and allowed little private sector input into privatization of state-owned enterprises. ${ }^{340}$ Tangri states that only limited divestiture took place as no agreement could be reached on what to divest and to whom the companies should be sold. ${ }^{341}$ Members of the ruling class faction not in control of the state, particularly those with connections to political rivals, lost access to government officials, particularly at key ministries, hindering development of their businesses.

Liberalization of markets under structural adjustment also threatened pre-existing domestic industries, but the PNDC failed to soften the blow. ERP policies created difficulties for industrialists in textiles, cosmetics, and plastics, as well as for commerical farmers in rice and cotton. Political opponents complained that the PNDC offered no assistance to domestic business to off-set the problems associated with liberalization. ${ }^{342}$ The PNDC instituted a tight credit policy and restricted lending by state-owned banks; lenders charged over $30 \%$ interest. In addition, markets liberalization enabled the importation of lower priced goods, often below the price of locally produced goods. The PNDC Secretary of Finance refused to agree to protectionist measures, citing World Bank rhetoric that state assistance promoted inefficiency. ${ }^{343}$ The unmitigated economic reform provided a check on accumulation by the rival faction of the ruling class that had dominated traditional industries.

The explanation for low private investment is far more complex than the policies or strategies of one regime, involving successive regime changes, contemporary

\footnotetext{
${ }^{340}$ Tangri, "The Politics of Government-Business Relations in Ghana."

${ }^{341}$ Ibid.

${ }^{342}$ Ibid.

${ }^{343}$ Nugent, Big Men, Small Boys and Politics in Ghana.
} 
development ideas, ideological differences, geopolitical location and global market conditions, among others. ${ }^{344}$ History suggests that confidence and willingness to invest in Ghana had also been negatively affected by previous regimes that overregulated the private sector; there was ónsignificantôprivate investment even before 1983 . $^{345}$ However, the PNDC does appear to have slowed the private accumulation of wealth of its rivals. As Arthur states, the strong anti-capitalist stance of the PNDC had a ćhilling effectôon entrepreneurs. ${ }^{346}$ The business community perceived itself to be threatened, particularly politicians in private business that opposed the PNDC.

\section{Local Power Centers: The Traditional Aristocracy}

The PNDC used the CDRs and CVCs to check the traditional aristocracy at the local level to prevent this faction from gaining strength, as outlined in Section 1 above. The PNDC strategy included constraints on the traditional aristocracyôs control over land and natural resources held in trust for subjects. The CDR institution helped to organize subaltern classes and supported local youth associationsôattempts to enforce control over stool resources and assert their power over local leaders. Local youth associations, with support from the PNDC Committees, monitored and reviewed land revenue paid to chiefs.

\footnotetext{
${ }^{344}$ Paul Kennedy, "Political Barriers to African Capitalism," Journal of Modern African Studies 32, no. 2 (1994).; Peter Arthur, "Promoting a Local Entrepreneurial Class in Ghana: The Issues and Problems," Canadian Journal of African Studies 39, no. 3 (2005).

345 Tangri, "The Politics of Government-Business Relations in Ghana." P 101

346 Arthur, "Promoting a Local Entrepreneurial Class in Ghana: The Issues and Problems," 435.
} 
A state daily column by an unidentified author stated that ñthe handling of compensation paid in respect of acquired stool lands in the country is a vexed issue..$^{347}$ The traditional aristocracy under the NRC/SMC often failed to account to subjects for compensation received from the state and private hands. In some cases, the NRC/SMC had never officially compensated communities for acquisitions; the process of obtaining land involved collusion between state officials and the traditional aristocracy so remained in the informal realm. Yet, stool subjects claimed that chiefs and their relatives made visible improvements in living conditions following the acquisition of land by the state. PNDCQ̂́ Interim Land Committees investigated cases in which customary subjects argued that chiefs had built new houses and started businesses using đ́kalabuleô or unofficial payments, for land. The Interim Land Committees ordered moneys collected by chiefs to be paid into the proper átool accountsôto be managed by local community groups. Subjects gained control over land revenue to use for local development projects, but deprived chiefs of a source of revenue. It also deterred the traditional aristocracy from transferring stool lands to build personal wealth. Chiefs that continued to sell land did so under greater scrutiny.

The NIC and other state bodies also investigated and took legal action on disputes over land and land-based natural resources. For instance, the PNDC intervened in conflicts over salt reserves at Songhor and Panbros. S. C. Appenteng began salt production after securing a long-term lease agreement from the Busia government. Three state-owned banks invested in Vaccum Salt Products Limited by 1975. The local PNDC

\footnotetext{
${ }^{347}$ In many cases, unnamed authors in state publications were state information officers or other officials. ñChiefs, Professionals and the Peopleôs Land,ò People's Daily Graphic, February 22, 1983, 3.
} 
Committees, however, made allegations of collusion and ókalabuleôbetween S. C. Appenteng, the traditional aristocracy and former state officials. S. C. Appenteng felt that the PNDC was ñarousing the local citizenry to challenge their legal rights to business. $0^{348}$ The PNDC cancelled Vacuum Salt Productôs Lease in 1991 and gave a state agency control over the project.

The close monitoring of land transfers and exploitation of land-based resources slowed the commercialization process that had gained pace under the NRC/SMC. PNDC support for the local Committees that sought greater control over stool and clan land and land-based resources constrained the traditional aristocracyố ability to accumulate resources. The process increased the power of the Committees and local youth associations, and limited the ability of the traditional aristocracy to provide both political and financial support to the Busia faction of the ruling class.

It is worth noting that the PNDC did not contain all business sectors and businesses. The PNDC targeted specific export industries to rebuild the Ghanaian economy, primarily cocoa, timber and gold, and gave them access to state officials denied to other businesses. ${ }^{349}$ The PNDC used 60m USD to rehabilitate and equip sawmills. It used another USD 131 million of IMF assistance and USD 92 million from the International Development Association grant for the cocoa industry. ${ }^{350}$ However, the PNDC also monitored wealth accumulation in the targeted sectors, and it did not protect

\footnotetext{
${ }^{348}$ Kraus, "Capital, Power and Business Associations in the African Political Economy: A Tale of Two Countries, Ghana and Nigeria," 402.

349 Ibid.

${ }^{350}$ Kwame Boafo-Arthur, "Ghana's Politics of International Economic Relations under the Pndc, 19821992," African Study Monographs 20, no. 2 (1999).
} 
the firms against legal and tax violations. Notably, the NIC investigated loss of state revenue and corrupt practices by timber firms, ${ }^{351}$ confiscating upwards of 15 Ghanaian and Lebanese companies. In addition, local CDRs attempted to stem illegal unlicensed timber felling in the forest to improve timber exports. ${ }^{352}$ Businesses in the PNDCô key economic sectors and in infrastructure development did accumulate wealth during the 1980s in Ghana, though under the stateôs watch.

\section{Creating Supporters: Dispersed Accumulation and ósmall Businessô}

The PNDC began to support small-scale industry and small entrepreneurs in the mid-1980s, creating allies in the process. Small-scale sector employment creation grew $6.5 \%$ per annum from the mid-1980s, compared to a mere $1 \%$ growth in the formal sector, and absorbed as much as $70 \%$ of the non-agricultural labor force. Those employed or self-employed in the small-business sector felt increased incentives for business without the need to have personal contacts in government. ${ }^{353}$ The new entrepreneurs contributed to the PNDCQ̂́ small, urban base.

The PNDC policy to expand and improve the transportation infrastructure also created support from related businesses. The transport sector also benefitted from trade liberalization and the increased importation of used vehicles and parts. Jeffries notes that transport service workers, such as mechanics, provided positive support for the PNDC in

\footnotetext{
${ }^{351}$ Some of those involved in illegal practices left Ghana to join the timber trade in Liberia and the Democratic Republic of Congo, according to interviews with forest management consultants.

${ }^{352}$ Former NIC Timber Sub-committee member, personal communication, June 2006.

353 Jeffries, "Urban Popular Attitudes Towards the Economic Recovery Programme and the P.N.D.C. Government in Ghana."
} 
late 1990 and early 1991. ${ }^{354}$ The Ghana Public Road Transport Union (GPRTU), which organized lorry and taxi parks and collected revenue on behalf of the state, also supported the PNDC. The PNDC gained additional support from domestic contractors supplying materials and labor for infrastructure projects, ${ }^{355}$ from major road construction to those building drains in urban areas.

Small business also benefitted from the foreign currency exchange liberalization. 356 Entrepreneurs with foreign currency exchange bureaus directly profited, but more broadly, Ghanaians working in foreign countries could now easily send money to family members. Families often used remittances to start small businesses and import goods for retail.

The PNDC justified its assistance to the small-scale sector through the positive effect on job creation; the sector employed manual labor and used simple tools. The policy position was also consistent with development thinking in some circles at the time. ${ }^{357}$ But, perhaps more importantly, the growth of small-scale industry and new, local contractors met the income distribution objectives of the regime. Large-scale commercial industry could lead to concentrated wealth, which could support an alternative center of power or provide financial support for the opposing ruling class faction. However, smallbusinesses accumulated wealth on a smaller scale and in a more dispersed manner. At the same time, the small-business sector offered the PNDC a means to gain popular support.

\footnotetext{
354 Ibid.

355 Nugent, Big Men, Small Boys and Politics in Ghana.

${ }^{356}$ Ibid. The state licensed 137 in Ghana and 79 in Accra in 1989.

${ }^{357}$ For a discussion of development debates on promoting the small-scale business sector, see: Arthur, "Promoting a Local Entrepreneurial Class in Ghana: The Issues and Problems."
} 
Mikell argues that the small-business sector offered the PNDC its greatest support, second only to rural producers, ${ }^{358}$ whereas Nugent observed that óld wealthôoriented towards the established political factions, in other words the Danquah-Busia faction.

In short, the PNDC discouraged large-scale private accumulation of wealth by the rival Busia faction of the ruling class and sought to disperse wealth among new entrepreneurs and small-scale businesses. The approach slowed private accumulation, and with it, the commodification of land.

\section{Section 3. Land Relations during the PNDC: A Countermovement (and}

\section{Back Again)}

The political strategy of the PNDC reoriented land relations that had threatened to explode under the NRC/SMC. The NRC/SMC regime sped up the commodification of land during the 1970s, as part of its strategy to build the personal wealth of the dominant faction of the ruling class and reward ruling class and traditional aristocratic clients. The NRC/SMC strategy also created localized social conflict over land relations. Subaltern classes demanded that chiefs account for land and land-based resource revenues. The NRC/SMC in turn used the coercive apparatus of the state both to impose land transfers that did not follow customary land rights or customary rules on chieftancy, and to suppress resistance by subaltern classes. The June 4, 1979 coup ended the NRC/SMC rule, and the subsequent December $31^{\text {st, } 1} 1981$ coup brought a new ruling class faction to power. How did the PNDC contain the land disputes that had built during the

\footnotetext{
${ }^{358}$ Mikell, "Peasant Politicisation and Economic Recuperation in Ghana: Local and National Dilemmas."
} 
NRC/SMC? How did the change to an alternative dominant ruling class faction alter land relations?

The PNDC created a counter-movement in land relations and slowed the development of the land-sales market. The PNDCôs position on land served two ends. First, the PNDC undermined the traditional aristocracyês domination of land and eroded its source of power. In doing so, the PNDC also prevented large-scale accumulation of land and landbased resources by the rival ruling class faction. Second, the PNDC obtained support from peasants and the urban poor as power over land and landed property shifted to their favor. The PNDC provided social organization, coercive power, and legal means for peasants to challenge traditional aristocratic control over land and land-based resources. As a result, local youth associations and other local groups gained power in land relations and allocated land to local youth to farm. The PNDC also provided the institutions and laws for the urban poor to resist the power of landlords. The PNDC used land as a political tool to suppress the rival ruling class faction that had dominated during the NRC/SMC, and to build a new base of political support among subaltern classes. The rapid land commodification process that had begun under the NRC slowed. How did the traditional aristocracy and the subaltern classes respond to the PNDCQ̂́ interventions? And how long did the PNDC sustain the counter-movement?

\section{$\underline{\text { State Coercive Capacity: Containing Violence }}$}

Shifting power over land allocation to favor subaltern classes and preventing the accumulation of wealth of the rival ruling class faction effectively slowed land 
commodification, but the disputes created under the NRC/SMC still had to be contained. The PNDCôs coercive apparatus and emphasis on increased security provided a critical means to contain this threat of violence over land. The intelligence apparatus collected information from local CDRs on potentially violent conflict and the location of weapons. Tightened border control limited the movement of arms into Ghana from the subregion. The PNDC deployed the Armed Forces to stem violent conflicts before they escalated, based on improved intelligence. Factions in land disputes, including those that overlapped with chieftancy disputes, could not easily acquire weapons or small arms, and the security service responded rapidly to threats of violence.

The PNDCôs Committees contributed to conflict containment through participation in the District and Regional Security Committees and using their coercive power to intervene in disputes locally. CDR records suggest that cadres gave greater attention to local land disputes involving arms, and immediately informed the national CDR secretariat. The presence of the Committees in towns and villages across the country likely also acted as a further deterrent, as the public perceived Committees to be armed and trained PNDC operatives. The PNDCôs approach to countering threats to its power also provided a means to quell the threat of violence arising from land disputes.

\section{Traditional Aristocracy: Reactions and Limitations}

The PNDC altered the role of the traditional aristocracy in national and local politics. It did not seek legitimacy through endorsements from chiefs or through a patron-client network built on chiefs and their subjects, as the previous ruling class faction had. Rather, 
the PNDC enabled its Committees to reduce the dominance of the traditional aristocracy and empowered subaltern rural groups. Not surprisingly, the traditional aristocracy objected to the actions of the PNDC and their local Committees.

The PNDC altered the basis of the traditional aristocracyô wealth. The CVCs examined the source of wealth of members of the traditional aristocracy and prosecuted chiefs and other customary leaders found to live in excess of their legitimate income. They also prevented the traditional aristocracy from allocating land or contracting natural resource extraction without accounting to the customary subjects. Chiefs lost the ability to control wealth from land and land-based resources, reducing their material dominance over their subjects.

In addition, the traditional aristocracy argued that the óevolutionaryôCommittees sought to usurp their customary role. Customary duties performed by the traditional aristocracy formed the basis of social reciprocity and obligation of subjects to chiefs. The CVCs and CDRs assumed many customary responsibilities of chiefs. CDRs intervened in the management of local land and land-based resources, the primary source of chiefly authority. In addition, CDRs arbitrated disputes over land, marriage agreements and theft between stool subjects. Depriving chiefs of carrying out these customary duties also undermined the subjectsôobligation to the chiefs and other customary leaders. Subjects could shift their obligation and loyalty to the CDRs and the PNDC more generally.

The PNDC did not seek to eliminate the chieftancy institutions entirely, and did not usurp customary religious roles. However, the PNDC did attempt to institutionalize the new local balance of power. In particular, the traditional aristocracy opposed PNDC Law 
114, the Head of Family Accountability Law. Law 114 gave subjects and family members a legal means to demand accounts on land and land-based resource revenue and to remove customary leaders that mismanaged land or other stool resources. Law 114 also placed customary matters, chieftancy succession and performance, into the secular court system. The PNDC, through the CDRs, assisted stool subjects and family members to use Law 114 to assert their power over land, resources and local politics. The PNDC disregarded the objections of the traditional aristocracy to Law 114 and the courts continued to enforce it.

Ultimately, the traditional aristocracy had little room to respond to the changes in local land relations that the PNDC had set in motion. Chiefs became fearful of CDRs and the organized youth associations. A number of chiefs accused of embezzling land revenues and mismanaging land resources left Ghana for exile. The communities installed new chiefs in their place favorable to the new power relations. Some chiefs eventually cooperated with CDR and youth efforts to investigate land transfers and introduce greater transparency in stool resource management in order to preserve their customary roles.

\section{Subaltern Classes: Peasants and ósocial Justiceôin Land}

The PNDC captured the public discourse on land injustice early in its rule. It continually pronounced its commitment to accountability in land allocation, proper land 
use and revenue distribution in the national media. ${ }^{359}$ The PNDC argued that land allocation should be transparent and not exploit local peasants and youth. It also took the position that the local aristocracy should not use land revenues and resource royalties for an opulent lifestyle, but to develop the local community that effectively ównsôthe land. The PNDC trained Committees in ideology and mobilization at a đ́adre schoolôset up by leading PNDC members. The áchoolôprepared áadresôto raise awareness of ruling class exploitation and to organize aggrieved youth against rural exploitation issues and inequalities, included those related to land. Mikkell observed that peasants developed a greater understanding of their relative class position over prior periods in history. Commmittees disseminated the PNDC position on ósocial justiceôin land in towns and villages across Ghana.

The PNDCôs notion of social justice in land reverberated with customary ideals. Youth associations often sought to preserve the historical, customary lines of access to land and norms of allocation, and to return to the ideal norms of social land relations that preceded commodification. Commodification had caused the youth to lose customary usufruct land rights to external, economically and politically powerful individuals in market-based competition. The youth associations that assumed greater control over land allocation associated themselves with customary stools, such that control over land and land allocation remained embedded in local social relations. CDRs assisted the youth in researching and documenting locally specific land rights, rather than creating new,

\footnotetext{
${ }^{359}$ See: Disputes over the sale of watershed lands, e.g. in Ashanti where chiefs had sold watershed lands for rice cultivation, Yaw Boadu-Ayeboafo, ñLand Disputes Threaten Farming in Boamang Area,ò People's Daily Graphic, February 2, 1984, 1.
} 
secular rights. In other words, greater subaltern control over land restored and maintained customary norms as the regulator of land relations, rather than the market, but with a higher level of state regulation. The increased power of the youth did not represent a total shift from traditional aristocratic control to state control, but a Polanyian q́rotective countermoveôto preserve historical land relations. ${ }^{360}$ The slowing of land commodification also enabled the stool subjects to remain on customary land to farm. ${ }^{361}$

The local youth associations often took the form of asafo groups, or local militias under other names. Historically, the asafo provided an organization for young men⿳⺈ struggles against the traditional aristocracy in Ghana; a system of checks and balances that helped to moderate relations between customary power holders and ócommonersô $\hat{0}^{362}$ In Kwahu, for instance, asafo companies in 1921 provided an organization to address economic grievances over plummeting cocoa prices and displacement from land sales for commericial cocoa farms. Kimble argues that the success of that movement hinged on the channeling of asafo group loyalties into a "new form of economic self-defense." ${ }^{163}$ The PNDCô ideas of social justice over land overlapped with the asafo ideals. CDR organizers in some places actually straddled the two institutions and used asafo terminology to explain the PNDCôs aims and philosophy. The convergence of

\footnotetext{
${ }^{360}$ Meikins Wood discusses state intervention during the Tudor and Stuart periods that slowed the rate of enclosures. See: Ellen Meikins Wood, The Origin of Capitalism.

${ }^{361}$ The PNDC developed a different policy in the mid-1980s for forest land and harvesting timber, and sought to prevent local youth from illegal chainsaw tree felling. This led to tensions in timber areas between the youth and the PNDC. See Kojo Sebastian Amanor, Global Restructuring and Land Rights in Ghana: Forest Food Chains, Timber, and Rural Livelihoods (Uppsala: Nordic African Institute, 1999). 362 "Transactions of the Historical Society of Ghana," 2 (1998).

${ }^{363}$ David Kimble, A Political History of Ghana: The Rise of Gold Coast Nationalism, 1850 - 1928 (Oxford: Clarendon Press, 1963), 50.
} 
terminology and social objectives gave the PNDC a level of legitimacy and social support in their interventions in land relations, particularly along the coast.

The customary notion of óouthôfurther created support for the PNDC. óYouthôin Ghana is not defined by chronological age, so can incorporate age groups into the 40s and 50s. Rather, óouthôsuggests low social status, an absence of propertied wealth, and financial dependency. ${ }^{364}$ The same notions of social justice that appealed to the asafo groups often resonated with the broader category of youth, locally termed ómall boysôor órerandah boysô The PNDC appealed to youth that felt excluded from property and accumulation. The PNDCôs stated aims of social justice created impetus for numerous grass-roots social organizations started by the youth, such as the One Man, One House Committee.

The slowing of land transfers from communal to private holdings, and the drop in contentious, social land conflicts, did not mean that land sales halted entirely. The implementation of the ERP and liberalization stimulated localized land demand, particularly in the Kumasi and Accra peri-urban areas. Then, the introduction of the District Assembly structure in the late 1980s created gaps in the coercive structure that enabled more land transfers. The PNDC could not sustain the countermovement in land relations through the move toward democratization.

\footnotetext{
364 Amanor, Global Restructuring and Land Rights in Ghana: Forest Food Chains, Timber, and Rural Livelihoods.
} 


\section{Section 4. Slippage in the Countermovement: The Transition to Elected}

\section{$\underline{\text { District Assemblies }}$}

The PNDC gradually accepted increased private participation in housing development toward the end of the 1980s. As indicated above, trade liberalization and availability of foreign currency for imports improved availability of building materials. Expatriate Ghanaians sent remittances to purchase land and building materials, particularly in the capital city, and returning Ghanaians used savings to build houses. ${ }^{365}$ In addition, real estate companies accepted advance payment through forex bureaus. Private real estate advertisements appeared in state dailies in 1989.

Urban planning scholars note that real estate developers operating in Ghana sought to substantially expand their land acquisitions at the end of the 1980s. ${ }^{366}$ However, the PNDC did not promote the interests of the real estate developers in land acquisitions. Rather, real estate developers often complained that the government failed to assist them in acquiring land. ${ }^{367}$ The PNDC banned órantsôof Ga lands in Greater Accra in February 1991 in response to increased fraud in the land-sales market, ${ }^{368}$ creating a significant impediment to acquiring large tracts of land for development. Local CDRs attempted to enforce regulations that limited the number of plots and the size of the plots that could be purchased by one person. Interviews with builders and the records of the CDR offices in Greater Accra suggest that individuals purchased land plots to build personal homes, not speculate in real estate or build commercial estates.

\footnotetext{
${ }^{365}$ Tipple, "Housing Supply in Ghana: A Study of Accra, Kumasi, and Berekum."

${ }^{366}$ Ibid.

${ }^{367}$ Real estate developer, personal communication, Accra, 1996.

368 ó Grantôreferred to the transfer of communal land to private freehold title.
} 
In addition, the CDRs sought to enforce a regulation that prevented the purchase of land by non-Ghanaians; all leases and transfers of stool or clan land required a Ghanaian counterpart. This regulation effectively blocked real estate or commercial development of land in Ghana by multi-national companies without a dominant Ghanaian partner. The enforcement of that regulation also slowed the process of commodification of land, as companies investing in Ghana following liberalization could not buy tracts of land to develop without significant state intervention.

Demand for land in Greater Accra and peri-urban Kumasi continued to grow toward the late 1980s. The move toward democratization with District Assembly elections in 1988 compromised the ability of the local CDR to intervene in land disputes and monitor land transfers. Ghanaians increasingly complained to state institutions about fraud and disputes over building plots. The PNDC Ministry of Works and Housing called a meeting with private real estate developers in 1988. The PNDC advised estate developers to establish the Ghana Real Estate Development Association (GREDA) to address the sudden surge in complaints over fraud in the land and real estate markets, but it could not reverse the rise in land disputes. Land litigation cases rose rapidly, from 13,000 in 1991 to 16,000 in $1993 .^{369}$

The Local Government Law (PNDCL 207) of 1988 created 107 District Assemblies, each with 22 departments and agencies. The institutional reform altered who had the authority to mobilize coercive force, for what purpose coercive institutions could be used, and how local accountability was interpreted and achieved. Old politicians,

${ }^{369}$ Tipple, "Housing Supply in Ghana: A Study of Accra, Kumasi, and Berekum." 
particularly those that had served on the Town and Village Development Committees under previous regimes since the 1950s, tended to dominate the two-thirds elected positions on D.A.s. ${ }^{370}$ The PNDC appointees, the remaining one-third of the Assembly membership, included members of the CDRs and chiefs. Chiefs made up one-fifth of the appointed membership, despite the lack of a formal provision for participation.

The shift to District Assemblies created local power struggles immediately after the 1988 elections. Nugent notes that the PNDC did not pack the Assemblies with loyalists, but appointed a significant number of professionals and old politicians from the opposition factions with their own political agendas. ${ }^{371}$ The PNDC made repeated calls for cooperation between District Assemblies and cadres. The PNDC did not give unequivocal backing to the Committees over other local state authorities. ñCadres urged to stop old attitudes, ò warned one article on the District Assembly institution. ${ }^{372}$ The article was one of the first written by ñGraphic Reporter,ò an unnamed, high-level PNDC member. Cadres subsequently redemarcated CDR Zones to coincide with electoral areas to improve cooperation with District Assemblies. ${ }^{373}$

Jurisdiction questions over land and rentals arose between the District Assemblies and CDRs. State officials urged District Assemblies to assume oversight of landlordtenant relations through Rent and Housing Committees within the Assemblies. ${ }^{374}$ Only rent courts in Accra continued to apply PNDC Law 138. Rent Officers elsewhere argued

\footnotetext{
${ }^{370}$ Nugent, Big Men, Small Boys and Politics in Ghana.

371 Ibid.

372 Graphic Reporter, ñCadres Urged to Stop Old Attitudes,ò People 's Daily Graphic, February 21, $1989,9$.

${ }^{373}$ GNA, ñRedemarcate CDR Zones to Coincide with Electoral Areas,ò People's Daily Graphic, February $27,1989,3$.

${ }^{374}$ GNA, ñEnsure Good Landlord-Tenant Relationship,ò People’s Daily Graphic, March 23, $1989,3$.
} 
that the state-mandated rents were unreasonable and ejected tenants who refused to comply with increased rents. ${ }^{375}$

Assemblies also asserted their power in land relations. They set up land tenure committees and enacted local land laws and regulations. The Ga District Assembly Secretary Major (Rtd.) Clerk advised assembly members at the inaugural meeting at Amasaman to stay out of land and chieftancy litigations, ${ }^{376}$ and PNDC officials warned elected Assemblyman not to get involved in chieftancy disputes, to little effect. ${ }^{377}$ The District Assemblies also moved coercive intervention in land disputes into police jurisdiction, ${ }^{378}$ despite the continued presence of the CDR District Organizing Assistant on the security committees at the district and regional level and the formal links between the CDRs, the NIC and the intelligence apparatus. The state media continued to report the PNDCQ̂ warnings against land disputes ${ }^{379}$ and state security interventions, ${ }^{380}$ but land relations had already begun another shift toward commodification.

\footnotetext{
375 Tipple, "Housing Supply in Ghana: A Study of Accra, Kumasi, and Berekum."

${ }^{376}$ GNA, ñStay away from litigations ï Clerk,ò People's Daily Graphic, May 5, 1989, 3.

${ }^{377}$ See: GNA, r̃Elected Assemblymen Cautioned Not to Get Involved in Disputes, ò People's Daily Graphic, January 4, 1989, 3; The Secretary of Fuel and Power, Ato Ahwoi, made a public statement against assembly members interfering in chieftancy affair, see: Asiedu Marfo, ñAssemblymen Not Kingmakers,ò People’s Daily Graphic, January 20, 1989, 3.

${ }^{378}$ Graphic Reporter, ñTwo Before Court for Encroaching on SHC Land,ò People's Daily Graphic, March 3, 1989, 8.; GNA, ñIGP Restrains Two Families from Entering Disputed Land,ò People's Daily Graphic, November 5, 1989, 9.

${ }^{379}$ Dwamena Bekoe, "Ahwoi Inaugurates Assembly," People's Daily Graphic, January 21 1989, 9.; Kate Hudson, "Sale of Farmlands by Rural Dwellers Perpetuating Poverty - Yankson," People's Daily Graphic, January 25 1989, 5.

${ }^{380}$ Abdul Aziz, "Bolga D.C.E. Probes Two Candidates," People's Daily Graphic, January 21 1989, 3.; Samuel Kyei-Boateng, "Settle Chieftancy Dispute," People's Daily Graphic, February 1 1989, 6.
} 


\section{Conclusion}

This chapter concludes by evaluating the changes in land relations during the PNDC period against the central questions of the dissertation. What was the PNDCôs approach to land in its strategy to retain power? Who benefitted and who was excluded? How did the PNDCôs strategy contribute to or ameliorate the rising social violence over land that began during the NRC/SMC?

Land violence decreased substantially soon after the PNDC came to power. The PNDCôs emphasis on security to ensure its political survival against numerous coup threats served to contain violence over land as well. Improved border controls and increased capacity in intelligence limited the flow of weapons into and within Ghana. The coercive institutions reacted quickly to dispel land disputes, alerted by the CDRs to those involving weapons. Locally, the increased presence and capacity of coercive institutions, particularly the local CDRs, created a deterrent against the use of arms in land disputes.

In addition, the political strategy of the PNDC supported a countermovement in land relations. The PNDC sought subaltern class support to retain power, and it used land as a means to gain that backing. The PNDCôs promise of justice in land relations, including equitable distribution of land and transparency in land revenue, often appealed to customary notions of accountability among the rural youth and ásafoôgroups. The CDRs provided a link between the PNDC and local supporters. The PNDC provided public support for peasant land rights in the state media and through officials, but also created institutions to facilitate a shift in land relations. The PNDC instituted legal reform to enable customary subjects to remove leaders for land or land revenue mismanagement. It 
also constrained chiefs by excluding them from a formal role in government institutions. Furthermore, the CDRs usurped many customary duties of the traditional aristocracy, notably arbitration in land disputes. Investigations also led by various revolutionary bodies forced the traditional aristocracy to return land revenue or land to customary subjects. These policies, enforced by the state coercive apparatus, served to increase the power of peasants over the traditional aristocracy. The óouthôand subaltern classes, in turn, gained access to farmland and increased local exploitation of land-based resources, such as salt. The traditional aristocracy had little means to resist, and some aggrieved chiefs left Ghana in voluntary exile rather than accept destoolment. The PNDC created a shift in land relations that benefitted peasants, particularly those in youth associations willing to work with the CDRs.

The PNDCôs pursuit of a base among rural and peri-urban subaltern classes to counter opposition from rival ruling class factions led to a land strategy that effectively slowed the commodification of land for real estate and rental property development. The PNDC $\hat{Q}$ revolutionary bodies intervened in landlord-tenants relations. They favored tenants through strict enforcement of rental caps, preventing evictions, and forcing landlords to let rooms at state mandated rates. The PNDC discontinued the NRC/SMC policies in housing, ending tax concessions for investment in real estate. It also confiscated the properties of former government officials that had unpaid loans to state banks. These policies curtailed speculative investment in land for real estate that had proliferated during the NRC/SMC period, further slowing land transfers from communal to private holdings. 
However, the PNDCQ̂́ political strategy that had suppressed land violence and fostered a countermovement in land relations was not sustained. The PNDC began to shift its approach to the land as it moved toward democratization. In 1988 and 1989, the PNDC restored some power to the traditional aristocracy in the new District Assembly institution, albeit below what the traditional aristocracy had enjoyed under previous regimes. In addition, the elected District Assembly administration provided members of the rival ruling class faction a means to exert institutional power over subaltern classes again. District Assemblies and CDRs struggled for control at the local level, including over land. At the same time, the PNDC began to de-emphasize the role of the security apparatus in retaining power.

The nature of the disputes over land began to change, as well. The security apparatus in the early 1980s had largely contained social conflict between customary authorities and communal subjects, and between the state and subaltern classes. Increasingly, however, disputes arose between the individuals purchasing land to which they held no customary rights. Foreign exchange liberalization enabled more individuals to purchase land plots with remittances and savings from work abroad. New real estate companies sought large tracts of land for private estate development in peri-urban areas. The traditional aristocracy began to sell land without recourse to customary subjects, and often without clear boundaries or demarcation. The secretive nature and opaqueness of the land transfer contributed to numerous land disputes between individual market participants. Disputants sought assistance from local District Assembly members, the remaining CDRs, the police, and in some cases, members of the Armed Forces to retain 
possession of plots. Land disputes began to rise again, just as the PNDC led Ghana into democracy.

A brief comparison of the NRC/SMC and PNDC periods suggests that the land sales markets do not emerge naturally, but are forged according to the interests of the ruling class. The nature of the ruling class, its factions, interests and strategies, create fluctuations in land relations and in the shape of the land sales market. In the case of Ghana, the NRC/SMC faction of the ruling class pushed land commoditization forward, as a means to accumulate wealth and remain in control over the state. The factional nature of the ruling class however, meant that the NRC/SMC attempted to exclude other factions of the ruling class from accessing land and land-based resources, as well as subaltern classes. This created resistance to the land transfers and tensions rose over land. The PNDC, representing an alternative faction of the ruling class, sought to build a support base from those excluded by the NRC/SMC. It supported local efforts by subaltern classes to increase their control over land resources, and suppressed the traditional aristocracy and rival ruling class factions. The PNDC further prevented violence over land transfers through increased state security capacity. The political interests of the PNDC effectively prevented rapid land commoditization, even in the early years of structural adjustment. Unlike the NRC/SMC period, the PNDCQ̂́ strategy led to a decline in land speculation and commercial investment in real estate. However, this countermovement in land could not be sustained. The PNDCôs political interests, and strategies, began to change as it moved Ghana toward democratization. 


\section{Chapter 5. Electoral Patronage, Privatized Coercion, and Land}

\section{Violence: Ghana under Democracy}

The Osu Traditional Council says the ruling New Patriotic Party is engaging in self delusion [sic] if it intends releasing Ga family lands in a bid to secure votes from the people. The council says it will engineer an electoral defeat of the NPP if the government does not release "all lands, " including stool lands that have been confiscated to the state over the years. In a statement released on Monday and prompted by government's announcement to release some family lands, the Osu chiefs said the move is a mere propaganda gimmick to win Ga votes. ${ }^{381}$

The previous chapter discussed the decline of violence over land during the PNDC rule, which related to the dominant ruling-class factionô shift in political strategy. The PNDC strategy to strengthen the coercive institutions to prevent potential coups also helped reduce land-related violence, because parties in land disputes lacked easy access to guns and other weapons, and the state coercive institutions helped contain local disputes from degenerating. In addition, the PNDC sought to retain power, in part, through building a support base among subaltern classes, a strategy pursued through institutional support and policies that favored subaltern interests in land at the local level, often against the traditional aristocracy. Finally, the PNDCôs economic reform policies and state revenue recovery slowed primitive accumulation in land, particularly by rival

\footnotetext{
${ }^{381}$ Fiifi Koomson, ñLands for votes: Osu warns Government,òAccessed October 14, 2008. http://news.myjoyonline.com/news/200810/21603.asp.
} 
factions of the ruling class. In sum, the PNDCQ̂́ strategy to protect itself against a rival ruling-class factionôs attempts to gain power contributed to the decline in land violence through increasing security capacity, bolstering subaltern classes in land relations, and constraining demand for land. However, the nature of the threat to power began to change as the PNDC moved Ghana toward democratization in the late 1980s. Administrative changes that followed local level district assembly elections initiated a reversal in the counter-movement in land relations. Land relations began to deteriorate as factions of the ruling class and the traditional aristocracy took advantage of the institutional reform period to re-assert their control over land.

This chapter addresses the transition period toward electoral democracy. It argues that democratic reforms played a key role in increasing the number of land disputes and their degeneration into protracted violence. The argument set out below does not dismiss the role of economic reform in changing land relations; economic liberalization did allow Ghanaians living abroad to send remittances to build housing which contributed to increase demand for peri-urban land and land prices. However, this alone does not explain an increase in land violence. The political strategies of the ruling class mediated the effects of economic reforms, and ultimately, shaped the nature of the emerging land market.

This chapter begins by examining ruling-class control over the democratization process, including the reduction of the effective role of the coercive institutions, and the new political strategy that accompanied a shift to elections. The dominant ruling-class faction no longer sought to capture subaltern support through land policies and 
institutions, in part because it had built a core of support among rural peasants. Rather, the new strategy entailed building electoral-patronage machines to ensure votes during elections. The next section addresses the means by which ruling-class factions sought to accumulate wealth to sustain patron-client networks, finance elections Factions needed resources that could enable them to maintain patron-client relationship and to finance future elections even during periods out of power. The third section analyzes the part played by the security services in the ruling-class strategy, particularly as the ruling class dismantled the PNDCôs ñrevolutionaryò institutions and then weakened the remaining ones. The chapter concludes by returning to the central questions of the impact of ruling class political strategies on land relations and the resulting violence.

\section{$\underline{\text { Section 1. Means to Access and Maintain Power: Electoral Politics }}$}

Ghanaôs democratization began with district assembly and local committee elections in 1989 and culminated with presidential and parliamentary elections in November 1992. The incumbent, Flt. Lt. Rawlings, retained power as an elected president with the National Democratic Congress (NDC) party. The country has since achieved two changes of the political party in power. The New Patriotic Party (NPP) won the presidency and the majority of seats in Parliament in 2000, signaling the first time Ghanaôs government executive was changed through an election. The NPP was re-elected in the 2004 election. The NDC returned to power in the 2008 election, which marked the second handover of party in power through the ballot box. The international community and scholars now generally accept the country as a democracy, despite some flaws in the 
founding 1992 election $^{382}$ and incidents of sporadic violence and rigging in the 2008 election by both parties. The ñ consolidationò of democracy in 2000, marked by an alternation of party in power, did not appear to modify the strategy of the opposing factions of the ruling class.

The acceptance of election results by all rival factions of the ruling class since 1992 does not reflect a unification of or consensus among the ruling class, though it does show some level of agreement within the ruling class on the election and democratic rules, processes and institutions. To the contrary, the factional nature of the ruling class has persisted and shaped the nature of Ghanaian democracy. The political parties formed in 1992 followed the divisions that originated in the anti-colonial struggle. The two primary rival ruling-class factions created parties that dominated the electoral space, and they co-opted the small parties during presidential elections. Most of the PNDC joined the National Democratic Congress, endorsed by small Nkrumahist parties, such as the National Convention Party and the EGLE Party. Personalities from the Danquah-Busia tradition, as well as some from the Akyeampong government (including Gen. Akyeampong $\hat{Q}$ wife), formed the New Patriotic Party. The zero-sum politics and struggle for control of the state and the nationô resources between these rival factions of the ruling class continued under democracy.

The nature of the ruling-class struggle for control over the state and resources is reflected in the institutions and policies that both parties adopted, beginning with the initial transition to democracy itself. The basis upon which the dominant faction of the

${ }^{382}$ Adu Boahen, "Ghana: Conflict Reoriented," in Governance as Conflict Management: Politics and Violence in West Africa, ed. I. William Zartman (Washington, D.C.: Brookings Institution Press, 1997). 
ruling class opted for regime change shaped the institutions formed with the transition to democracy. The PNDCôs 1992 announcement lifting the ban on political parties and scheduling national presidential elections grew, predominantly, out of pressure on the PNDC from external donor agencies for reform. ${ }^{383}$ Ongoing internal regime consultations assessed that democratization was necessary to enable the country to continue to receive donor assistance, and moreover, that the PNDC had the ability to retain power in democratic elections, particularly through the subaltern and rural vote organized by the CDRs. In other words, the decision to make a transition to democratic rule came primarily from inside the regime, rather than from pressure by civil society. Bratton and van der Waalôs review of the transitions to democracy in Africa also noted the absence of strong domestic agitation for democratic elections in Ghana. Rather, domestic pressures for democratization, such as rallies and protests, followed the regimeâs decision to move toward democracy and toward the announcement of district-level democratic elections in the late 1980s. Leading members of the rival faction of the ruling class, such as the future presidential candidates Adu Boahen and Nana Akufo Addo, dominated the domestic calls for democracy. Newspaper reports and interviews with former PNDC officials suggest that the PNDC did not make the transition to democracy under threat from public lectures and rallies favoring democratic elections from the rival ruling- class faction; instead, it made the move more immediately in reaction to external threats to cut foreign aid.

The PNDCôs internal decision to liberalize the political process gave it the ability to control the process of democratization. The PNDC and subsequent NDC could,

${ }^{383}$ Former PNDC public servants, personal communications, Accra, 2008. 
therefore, create new institutions that suited its own interests. In short, it sought to establish institutions to further its control over resources, which would enable it to dominate permanently the rival ruling-class faction. It is not surprising that the NPP created institutions and implemented a strategy to eliminate the rival faction during its time in power. Indeed, both ruling class factions, through the successive changes in the dominant rival faction in power, subordinated the interests of subaltern classes to their own interests when they were formulating new institutions and policy. This is reflected in policies and institutions that manage and regulate land and in the escalation of violence in the land market after democratization.

\section{New Electoral Threats to Power}

Democracy changed the type of threat to ruling-class dominance. While the acceptance of the rules of democracy implied peaceful transfers of power, it did not guarantee that coups would no longer occur. In the case of Ghana, ruling-class acceptance of elections as the new means to gain power, along with assurance from the international community that it would defend elected leaders, altered the political calculus.

The threat of losing control over the state through a coup seemingly declined during the early 1990s in Africa. Stated otherwise, assuming power through a coup had become less viable and carried higher risk. The international community began to provide security assurance to elected leaders, taking military action if necessary to prevent coups and to restore constitutionally elected leaders who had been removed through coups or force. For instance, the United Kingdom assisted in securing Tejan Kabbahô power in 
Sierra Leone, and the U.S. attempted to support an elected leader in Haiti. In addition, in 2000 the African Union issued the Lome Declaration on unconstitutional coups, which barred leaders of coups from certain activities in the organization. It then exercised this authority by restoring overthrown President de Menzies to office in 2003. ${ }^{384}$ This gave the ruling class in Ghana confidence in democratic politics and its electoral outcomes.

In democratic Ghana, political actors remain the same, but the way rival ruling class factions sought and retained power changed. To begin, the electoral process largely removed the coup threat with democratization. Equally important, the faction of the ruling class in power could no longer rely on the coercive institutions of the state to remain in power. The coercive apparatus of the state, therefore, declined in importance as a means to gain and retain power, and building election machinery gained priority.

\section{Seeking Votes: Building a Political Client Base}

The logic of electoral democracy demanded a new ruling-class strategy and the ñewò political parties turned to patronage. Lindbergh defines neo-patrimonial politics as ñensuring personal favors and benefits, often at the expense of public concerns and resources, ò which he distinguishes from liberal democratic politics that focus on ñpublic policies, political programmes and prudent use of national resources..$^{385}$ Lindberghôs study of Ghanaôs Parliament supports the assertion that elected officials increasingly

\footnotetext{
${ }^{384}$ African Union, Communique, Ninety-third Ordinary Session at Ambassadorial Level of the Central Organ of the Mechanism for Conflict Prevention, Management and Resolution, (Central

Organ/MEC/AMB/COMM XCIII) 24 July 2003, Addis Ababa, Ethiopia. Accessed at: http://www.africaunion.org/News_Events/Communiqu\%C3\%A9s/Communique\%20\%28Eng.\%29\%2024-07-2003.pdf

${ }^{385}$ Lindbergh, ""It's Our Time to Chop", 123.
} 
utilized patronage to reproduce their power since the 1992 inception election, spending both an increasing amount on elections and a higher proportion of income on personal ñgiftsò to constituents. ${ }^{386}$ Sandbrook and Oelbaum reached a similar conclusion on the resurgence of patronage after finding a 70\% increase in core civil servants between 1992 and $1995 .^{387}$ A quantitative study likewise found $27 \%$ more education spending in districts where the ruling party won the Parliamentary elections. ${ }^{388}$ These studies, as well as another by Aidoo, ${ }^{389}$ present a picture of increasing patronage between the politicians and constituents.

Personal contact with each voter is one means that political parties adopted to acquire support, but it is an inefficient method for presidential candidates who must reach voters nationally. National, and even Parliamentary elections require intervening actors to reach small groups and individuals. In other words, the ruling class needs intermediary patrons at the local level to build and sustain a national patron-client network. In Ghana, the process of decentralization that created district assemblies and the reforms made to the institutions that regulated relations between the state and the traditional aristocracy provided such local patron-clients.

Decentralized Patronage: District Assemblies and the Creation of Local Patron-

\section{Client Networks}

\footnotetext{
${ }^{386}$ Ibid.

${ }^{387}$ Richard Sandbrook and Jay Oelbaum, Jay, ñThe Politics of Economic Decline in Ghana.ò Democracy and Development 2, no. 3. (September-December 1999): 19-20.

${ }^{388}$ Edward Farhan and Zaidi Miguel, Do Politicians Reward Their Supporters? Public Spending and Incumbency Advantage in Ghana (University of California, Berkeley, 2003).

${ }^{389}$ Thomas Maxwell Aidoo, "Political Involvement in a Democratizing Neo-Patrimonial Polity: The Case of Ghana - 1992-2000," Research Review: Institute of African Studies 22, no. 2 (2006).
} 
The district assemblies, transformed from the non-democratic district councils in 1989, officially sought to deconcentrate government institutions to the local level to improve administration. The PNDC also claimed that the Assemblies contributed to the creation of non-party, democratic governance, and democratization began in Ghana with the election of 70 per cent of the district assembly bodies in $1989 .{ }^{390}$ Nugent argues, however, that decentralization provided the basis to mobilize the ñural eliteò as part of a political base. ${ }^{391}$ The new institution certainly offered the dominant ruling-class faction links to local business, the traditional aristocracy and subaltern populations. An extensive study of the institution and outcomes concludes that the assemblies remain under central control with little autonomy. ${ }^{392}$ Ultimately, the institution ensures that the Presidency exercises extensive control over the district government, by legislating that the President appoints the head of each assembly, the district chief executive (DCE), and 30 per cent of the assembly. The district assembly implements government policy, but, more important, awards and manages most contracts for infrastructure, procures some of the supplies needed in each district, and distributes central government supplies. The district chief executive is at the same time beholden to the Presidency and the ruling class faction in power. The DCE and assembly members serve as important figures in creating and reproducing the patron-client network at the local level.

\footnotetext{
${ }^{390}$ Richard C. Crook, Manor, James, "Ghana," in Democracy and Decentralisation in South Asia and West Africa, eds., Richard C. Crook and James Manor (Cambridge, New York and Melbourne: Cambridge University Press, 1998).

${ }^{391}$ Paul Nugent, Big Men, Small Boys and Politics in Ghana.

392 Crook, "Ghana."
} 
The district assembly structure also reflects the increased authority of the traditional aristocracy at the local level. The dominant faction of the ruling class integrated the traditional aristocracy into governance with the reform of local government institutions under the 1992 Constitution. Article 255 (1c) and Act 462 Section 141 (1c), gazetted in 1993 after the 1992 election, mandate that each regional house of chiefs elects two representatives to serve on the regional coordinating council. This body makes decisions on policy and security matters for each of Ghanaôs ten regions. In addition, Article 242 (d) and the Local Government Act (462), Section 5 (d) state that the President must consult chieftaincy authorities in appointing the non-elected 30 per cent of each district assembly. The President may also choose a chief to serve on an assembly. The ruling class in taking these actions appeared to prevent the overlap of national, customary and political interests, but it then gave chiefs an official role in both regional and local governance. The ruling class and the traditional aristocracy have used the new role to their advantage, gaining greater control in local land relations.

Redefining the Relationship between the Ruling Class and Traditional Aristocracy: $\underline{\text { Prohibitions and Alliances }}$

During democratization, the ruling-class factions reached consensus on returning to chiefs a role in governance, enabling them to overcome hindrances posed by the weakened position of the chief during the PNDC period. Institutions created during the transition to democracy restored some local power to the traditional aristocracy. Other newly created institutions seemed to attempt to give the traditional aristocracy greater 
independence from political interference by the ruling class, but this attempt ultimately yielded unintended consequences.

\section{Formal Separations between Politics and Customary Authority}

The new Constitution of the Fourth Republic of 1992 prohibited the state from interference in chieftaincy affairs. For the first time, official recognition or destoolment could occur only through the National House of Chiefs, rather than through a state ministry or the executive. Article 271 (2) of the Constitution states:

Parliament shall have no power to enact any law which (a) confers on any person or authority the right to accord or withdraw recognition to or from a chief for any purpose whatsoever; or (b) in anyway detracts or derogates from the honour and dignity of Chieftaincy.

In addition, the 1992 Constitution (Articles 271-274) made provisions for arbiters in chieftaincy matters to regulate the traditional councils at the local level, the regional house of chiefs for each region, and the national house of chiefs as the highest level, in the absence of state authority. Each of these bodies has a judicial committee with jurisdiction over disputes over chieftaincy positions. The committee is tasked with hearing disputes over stool occupancy, with procedures for appeal that proceed up a chain of authority to the national level. Only when that process has been exhausted and cases meet specific criteria can a case be taken to the statê̂ courts for adjudication.

Furthermore, Article 276 of the Constitution banned chiefs from taking part in

ñactive party politics. ̀̀ A chief may not stand for an elected position as a party member. 
Accordingly, members of the traditional aristocracy must be neutral in dealing with party candidates. Chiefs photographed or filmed at political events must publicly declare that they do not support the candidate whose event they are attending, or they must abdicate the position of chief. Such measures allegedly seek to create a boundary between customary and party politics, to prevent customary interests from overriding national interests, and to safeguard the customary institutions and customary subjects.

\section{Traditional Aristocrats and Alliances: Building Patron-Client Chiefs}

The constitutional provisions appear to reduce the ability of the ruling class to control the traditional aristocracy. However, the provisions did not change actual practice. Each rival ruling class faction actively engages in customary politics, seeking to promote favored chiefs who will provide them access to voters and local resources. In addition, many members of the traditional aristocracy violate the ban on active participation in politics; chiefs, linguists and other customary functionaries make their choice for a candidate clear to the community, including attendance at party functions, such as rallies. Politicians perceive that an endorsement by a member of the traditional aristocracy, particularly a chief, can significantly improve votes among the customary subjects. ${ }^{393}$ In short, the ruling-class factions place great importance on ensuring the position of a favored chief to support the patronage system.

The ruling-class factions each support candidates when a position becomes vacant in the traditional aristocracy, offering financial incentives, ñmacho-menòthugs, and

\footnotetext{
${ }^{393}$ Exceptions exist where chiefs do not possess significant influence over voters, as occurs increasingly in the urban areas.
} 
political promises to the ñkingmakersò to choose their candidate. ${ }^{394}$ They also send local political clients, mostly members of ñyouth associations,òto protest the appearance of a rival candidate, even advocating the use of violence. ${ }^{395}$ Influential individuals act as ñchieftaincy contractors, Òidentifying prospective traditional leaders and managing their ñcampaignsò within the traditional structures, through the Traditional Councils up to the National House of Chiefs. ñChieftaincy contractorsò existed prior to the 1992 transition, but have increasingly become involved in advocating for a particular stool candidate to gain control over land. Indeed, these contractors secure promises of large tracts of land for re-sale and land-based resource concessions in payment for their services and in repayment for money lent to pay off those involved in selecting the chief. In addition, the contractors often provide links to state officials and members of the judiciary who may be called upon to enforce the rulings of the Traditional Councils and the National House of Chiefs. $^{396}$

An additional benefit of the realignment of relations between the ruling class and the traditional aristocracy is that chiefs and other members of the traditional aristocracy can provide access to land and land-based resources and can override the interests of the subaltern classes. At times, ruling-class access to land and land-based resources motivates the alliance with the traditional aristocracy, though this can undermine the legitimacy of chiefs as patron-clients.

\footnotetext{
${ }^{394}$ Mark-Anthony Vinoko, "Minister Dabbles in Stool Affairs," Ghanaian Times, 16 October 2002, 1.

${ }^{395}$ Member of a Ga traditional council, personal communication, Accra, 2006.

${ }^{396}$ Aning, ñChieftaincy, Land Conflicts and Conflict Resolution Mechanisms in Ghana.ò
} 
Chiefs and other members of the traditional aristocracy also benefit from positioning themselves as local patron-clients. Parliamentary and presidential candidates negotiate payments with chiefs in cash (and gin or schnapps) for entry into their customary areas. One Member of Parliament complained of the increasing amount of financial compensation being demanded by chiefs to enter a customary area. Payments of approximately 200 USD per chief, with more than ten chiefs within the constituency, placed a financial strain on his campaign. Payments made to chiefs to secure loyalty can cost the equivalent of several thousand dollars, sometimes collected from both major political parties. In addition to direct payments, chiefs also use their alliance with the district assemblies to acquire infrastructural development, primarily electricity, for customary land, which raises land values for private sale. ${ }^{397}$

The institutions created at the time of the democratization became instruments of patronage for the ruling-class factions, whether intended or not, and weakened the subaltern classesôability to make demands and pursue their interests. For instance, customary Judicial Committees failed to function as effective arbiters in the majority of customary areas. Members of the committees are commonly engaged in disputes over position themselves and are most often linked to disputes over land allocation and land revenues. Members make agreements with each other and with the ruling-class factions simply to fail to make a ruling or to rule in a particular way. Committee members also demand ñsitting feesò from disputants to ñwarm the seatò of each committee member at

${ }^{397}$ Member of Parliament, personal communication, Accra, 2007. 
meetings; ${ }^{398}$ these fees are paid in addition to official court fees, making it difficult for subaltern classes to afford access to the customary courts. The paramount chief might also manipulate the composition of committees to ensure a favorable outcome for himself or a sub-chief. This is particularly problematic, as paramount chiefs claim a percentage of revenue accruing from natural resources and land within their paramountcy from chiefs of lower ranks.

Moreover, judicial committees have had a detrimental effect on land relations for the subaltern classes and provide the ruling class with a means to control land. The committees lengthen disputes over chieftaincy and land, particularly as aggrieved disputants continue to appeal to higher levels and cases are delayed at each level. Extending the period over which disputes remain unresolved works to the advantage of the ruling class and traditional aristocracy. The official and informal fees that accumulate over lengthy sittings of the committees make the customary committees inaccessible to most Ghanaians. In addition, delayed rulings encourage private or ñself-helpò,violence to control land by protecting it physically. This also benefits the ruling class, as it is better able to contract and arm private guards and militias. Members of the traditional aristocracy further benefit as they often supply disputants with ñland guardsò from their customary areas. Chiefs and their customary subjects, often referred to as ñretainers,ò then argue that the land guards are the stoolôs asafo group and claim that they therefore fall under ñchieftaincy mattersòoutside of the stateố jurisdiction.

\footnotetext{
${ }^{398}$ Joseph R. A. Ayee, "Conflict Resolution and Grievance Redressing Mechanism at the District Level in Ghana: Myth or Reality," in ed. Mike Oquaye, Democracy and Conflict Resolution in Ghana (Accra: GoldType Publications, 1995). This was also supported by separate interviews with two members of customary authorities in Accra, 2006, and a lawyer, Accra, 2007.
} 
Further, the presence of the traditional aristocracy in the district assembly undermined local government functions and fed disputes over stool occupancy as well as quarrels over land and land-based natural resources. As Ayee notes, ñ[As] past experience has shown, institutional representation is untenable because the chiefs will transfer litigation and disputes over stools and skin to the district assemblies and the subdistrict structures, thereby creating factions where one needs a concerted front for local development. o $^{399}$

Thus with the advent of democratic politics, the ruling class sought to use patronage as the means to gain power. This strategy realigned the relationship between the ruling class and the traditional aristocracy, transforming the latter into ñmiddlemen,ò or local patrons. The ruling class created ineffective institutions that officially placed the traditional aristocracy in control of its own affairs, but at the same time, allowed the ruling-class factions to pursue their interests. Official state neutrality in chieftancy and customary matters provided the basis upon which the state could fail to act. Unofficially, each faction promoted the candidates for chieftancy with whom it could collaborate. The ruling class subordinated the interests of the subaltern classes in these patronage arrangements. Land and housing policies neglected the poorest farmers and urban dwellers.

The Neglect of Policies and Institutions: Land and Housing

\footnotetext{
${ }^{399}$ Joseph R. A. Ayee, "Some Thoughts on the Institutional Representation of Chiefs in the District Assemblies and the Sub-District Structures," in Chieftancy in Ghana: Culture, Governance and Development, ed. Irene K. Odotei and Albert K. Awedoba (Accra: Sub-Saharan Publishers), 60.
} 
The role of land and housing in politics shifted drastically with the transition to an elected government. The previous chapter discussed the way in which the PNDC gave land prominence in its strategy to gain subaltern support, capturing the public discourse on land and using the ñrevolutionaryò bodies to enforce claims to land and land-based resources by customary subjects. The PNDC also sought to build urban support among subaltern classes through housing policy, by enforcing rent caps and constraining demand for excessive rent advances. However, following the transition to democracy, political parties began to avoid taking a public position on land, and, for the most part, they dropped discussion of rent caps and limiting advance rent payment. Land and housing did not figure prominently in gathering support from voters, as it had under the PNDC, because the ruling class sought support through patronage rather than substantive policy.

\section{Land Policy}

The political parties noticeably began to avoid discussion of subaltern rights to land as an electoral issue following democratization. Parliamentary candidates and party organizers stated that they deliberately refused to discuss land during active campaigning, as they feared a loss of votes from the traditional aristocracy or stool subjects who felt aggrieved over exclusion from the opportunity to control land. ${ }^{400}$ Even candidates who were former members of revolutionary bodies admitted to avoiding the land issue while campaigning. Furthermore, candidates and party organizers resisted attempts by the subaltern classes to press candidates into answering questions about land issues,

${ }^{400}$ Former MP, personal communication, Accra, 2007; Sitting MP, Accra, 2007. 
removing speakers from platforms and leaving rallies to do so. ${ }^{401}$ In the late 1990 s, one M.P. raised the issue of land disputes in Parliament following a high-profile land guard case in 1998-9, but the government largely ignored the call for action. Land effectively ceased to be the subject of public, political discourse following democratization (with the exception of technocratic policy positions on land title reform, which were not subject to debate).

The political rhetoric shifted post-1992, but the official position on land remained relatively stable across subsequent changes of the party in power. The government of Ghana continued to pursue a land-titling policy through the Land Administration Project with external funding and continued to make promises to improve the land-tenure system to encourage private-sector investment in agriculture and in providing housing needs. ${ }^{402}$ The government of Ghana across both ruling-class factions also promised to establish land banks to ease the acquisition of land by private and foreign investors. ${ }^{403}$ The emphasis continued to be on formal titling as a means to address land-related problems experienced by the private investor, despite the worsening of litigation and rising violence over land. A broad selection of society, including members of the legal profession, public servants, members of the traditional aristocracy, and real estate

\footnotetext{
${ }^{401}$ Youth leader, Jamestown, personal communication, Accra, 2006.

402 See: Samuel Kyei-Boateng, "Efforts to Solve Land Sector Problems," Daily Graphic, 19 May 2006, 47.; A. Kofoya-Tetteh, "'Streamline Land Administration'," Daily Graphic, 17 April 2006, 21.; GNA, "Govt. to Streamline Land Tenure System," Daily Graphic, 26 April 2007, 43.

${ }^{403}$ See: Lucy Adoma Yeboah, "Boost for Investors - Frustration over Land Acquisition Cleared," Daily Graphic, 4 April 2007, 1.; "Editorial," Daily Graphic, 10 April 2007, 3.
} 
developers, point out that the LAP has not resolved the opacity in the titling process ${ }^{404}$; moreover, it has not clarified enforcement of titles. Further, a title does not guarantee valid ownership, as titles are granted even where ownership has not been verified. ${ }^{405}$ In addition, the prohibition on state interference in chieftaincy matters provided the ruling class with a means to claim that it could not interfere in land disputes or local land issues. The government of Ghana, on the one hand, endorsed donor-funded efforts to establish Customary Land Secretariats to process customary land acquisitions more efficiently. Yet it refused to intervene in existing disputes. The Head of Title Registration stated that land disputes are all caused by chieftaincy problems, and as such, the registry cannot take any position on a land dispute. ${ }^{406}$ Yet the registry continues to register lands known to be at the center of dispute. The refusal of intervention in land disputes at times extended to denial of enforcement of title by official bodies, including the police, when disputes arose over stool lands. In short, state officials argued that the 1992 Constitution prohibits state interference in chieftaincy affairs and therefore bars any intervention in disputes over customary lands.

With democratization, land moved from being a tool through which a faction of the ruling class gathered support to maintain its dominance, to an issue perceived to be inimical to building a patron-client network. Disputes over land divided members of the traditional aristocracy, the subaltern groups as well as clans. These divisions threatened

\footnotetext{
${ }^{404}$ The number of steps in the titling process has been identified and mapped as high as 43 . For an overview of the process, see: Wordsworth Odame Larbi, ñUrban land policies and the delivery of developable land in Ghanaò (PhD diss., Department of Land Management and Development, University of Reading, 1994).

405 "Land Guards Arrested at Ashaley Botwe," Ghanaian Times, 19 February 2010, 21.

${ }^{406}$ Chief Registrar of Lands, Land Title Registry, personal communication, Accra, 2007.
} 
the ability of the ruling class to build patron-client networks around local chiefs and political leaders. Official pronouncements on land generally coincided with public events related to the donor-funded Land Administration Project. The ruling-class shift on land relations occurred amidst a growing and increasingly violent land market, including an extensive encroachment onto public lands and the widespread sale of public lands to private individuals. The change in the land market rapidly pushed out the peri-urban farms surrounding the major cities and displaced customary occupants. Clearly, land had not ceased to be significant to local social relations and the economic development agenda, but the significance of land changed with the transition to electoral politics. First, land provided a source of revenue for the ruling class and a source of finance for political parties. Second, local land disputes often became the subject of political party disputes, as disputants, to no onê̂ surprise, split along party lines. These changes in land relations will be discussed in Section 4 below.

\section{Real estate development: Housing}

In Ghanaôs history, land demand tended to be driven in large part by housing policy. The drive to build estate housing by state corporations drove a rise in demand for land during the SMC period, for instance, and constraints placed on landlords during the PNDC period discouraged investment in rental housing. An overview of the trends suggests that housing should be an urgent political issue for Ghanâ̂ voters since 1992. The annual housing deficit per year since the 1990s has stood at an estimated 80,000 . The Ghana Real Estate Developers Associations estimated the housing shortage in 2005 to be 
970,038 . The housing that exists is increasingly of a poor standard. Additionally, the 2000 national census found that out of the counted 3,877,418 dwellings, 1,695,443 could not be considered conventional houses, i.e. kiosks, container shops, storefronts, shacks, etc. ${ }^{407}$ Nationally, $49.9 \%$ of households, averaging 5.1 persons, sleep in one room. In the capital, Accra, the figure reaches $62.9 \%$ of households sleeping in one room. Slums continue to grow, with over 50\% of Ghanaôs population living in urban areas and 70\% of the urban population living in slums; around a fourth of the population now live in slums. ${ }^{408}$ The statistics suggest deplorable housing conditions for the majority of Ghanaians. Yet, political party manifestos and campaigns since 1992 have tended to gloss over the issue of housing.

Official Government of Ghana statements on housing, as in land, changed little across political parties. In general, the government seeks to encourage private investment in housing and rental properties. That said, the governmentồ last housing policy dates to 1993. The most recent attempt to create a policy document remained in draft form across two changes in ruling party and continued to be discussed at ñstakeholderò meetings for years.

The number of real estate developers in Ghana surged in the late 1990s. ${ }^{409} \mathrm{~A}$ study found that $70 \%$ of the houses built by real estate developers exceeded a price of GHC 50,000 (USD 43,100) in 2007. Houses in gated communities in Accra and other

407 GREDA, "Ghana Housing Report: A Discussion Paper Submitted to the IFC" (Accra: Ghana Real Estate Developers Association, 2009).

${ }^{408}$ Godfrey K. Nyanney, "5.5 M Ghanaians Dwell in Slums," Ghanaian Times, 20 January 2009, 1.

${ }^{409}$ S. Osei Kwame and F. Antwi, "The Impact of Land Delivery and Finance in the Supply of Residential Accommodation in the Urban Centres of Ghana: The Case Study of Accra, Tema and Kumasi" (MSc. Thesis 229, Department of Real Estate and Construction Section, Real Estate and Construction Economics, Royal Institute of Technology, Sweden, 2004). 
urban centers, which began to emerge in the 1990s and extended rapidly after 2000, can sell in foreign currency for prices upward of USD 500,000. The investment in gated communities by the private sector totaled USD 434.8 million at 2005 values, the equivalent of the total foreign direct investment between 1999 and $2003 .{ }^{410}$ Grant attributes this development in housing predominantly to the liberalization of remittances into Ghana. ${ }^{411}$ Those with foreign currency buy modern housing at prices well above average incomes, leaving the remainder of the public living in substandard housing and slum conditions. Grant also notes the development of a land market in this process, as all the gated communities have been built on land acquired from customary owners. The cost of ñexecutiveò houses exemplifies the disparity in housing between Ghanâ̂ ruling class and its subaltern classes. Malpezzi and Mayo conclude that the capital city of Ghana suffers from one of the worst house-price-to-income ratios across developing countries. ${ }^{412}$ It is not surprising, then, that the ruling class resists the inclusion of housing in the political dialogue, while each ruling-class faction favors certain real estate developers. Even the leadership of the national body GREDA tends to change with each electoral change in party, with GREDAôs president tending to align with the ruling party. The estate developers, in turn, provide financial support to the allied political party, notably the one that provides preferential access to power. ${ }^{413}$ The government of Ghana, with

\footnotetext{
${ }^{410}$ Richard Grant, "The Emergence of Gated Communities in a West African Context: Evidence from Greater Accra, Ghana," Urban Geography 26, no. 8 (2005).

${ }^{411}$ Ibid.

${ }^{412}$ S. Moyo S. Malpezzi, "The Demand for Housing in Developing Countries," Economic Development and Cultural Change 35 (1997)., as cited by Grant, "The Emergence of Gated Communities in a West African Context: Evidence from Greater Accra, Ghana."

${ }^{413}$ This cannot be verified through accounts provided to the Electoral Commission, because the accounts do not accurately detail contributions. The donations from real estate companies to political parties have been
} 
technical support from the World Bank, attempted to provide incentives to developers to improve the housing supply. In 1994, Ghana passed the Ghana Investment Promotion Council Act 478 (b) to provide real estate tax exemption for foreign companies on the sale or rental of residential houses for five years. Real estate companies ensure continued benefits by closing and re-opening under new registration after five years, ${ }^{414}$ with the tacit assistance of the aligned ruling-class faction in power.

The government of Ghanaôs tax and mortgage policies encourage the development of the formal real estate industry, but estate developers neglect the lowincome housing market populated by the subaltern classes. Indeed, formal estate developers supply only about $10 \%$ of total housing stock. Private individuals supply the majority of housing, funded primarily through savings and remittances outside the mortgage industry. The lack of urgency placed on housing by the ruling class is exemplified by the failure to adopt a national housing and human settlement policy. Clearly, the transition to electoral democracy failed to lead to a favorable response to the subaltern classesôhousing crisis. At the same time, the ruling-class position on housing did encourage the proliferation of private real estate companies and land speculators.

Thus, the ruling class shifted to a strategy of patronage to gather votes. It sought ñmiddlemen,ò local patrons who would create and maintain patron-client networks. The ruling-class faction in power at the time of the transition restored the power of the traditional aristocracy at the local level through district and chieftaincy institutions. In

relayed through personal communications with the a senior member of a political party and a real estate company executive.

${ }^{414}$ GREDA, "Ghana Housing Report: A Discussion Paper Submitted to the IFC." 
addition, it created district assemblies that could be manipulated by the central executive, and it gave the appointed district chief executive the power to grant contracts that also positioned him/her to build and maintain patron-client networks at the local level. The patronage strategy led to two important changes in local land relations. First, shifting power in favor of the traditional aristocracy and away from subaltern classes gave the traditional aristocracy greater control over land and land-based resources. The transition to the 1992 Constitutional rule and the withdrawal of the Head of Family Accountability Law left subaltern classes with little control over land. Second, the dominant faction of the ruling class ceased to use land and housing as a means to gather political support from subaltern classes against the rival faction. However, land did not cease to be critical to the survival of the ruling-class factions. With the coming of democracy, the instrumental value of land became more critical to the accumulation of resources to finance elections and to further private accumulation of the ruling class.

\section{Section 2. Means of Accumulation: Election Financing, Patronage and}

\section{the Market}

The ruling class factions needed more resources to manage the cost of election campaigns and the recurrent expense of patronage to gain and retain power than under previous regimes. The ruling class political strategy had to address the acquisition of such resources. Additionally, factions out of power had to find non-public sources of finance to continue maintaining their patronage and mount future electoral campaigns. This need 
for a continual source of finance was peculiar to the democratic dispensation and figured prominently in the accumulation strategies of the ruling class factions.

\section{$\underline{\text { Electoral Campaigns }}$}

Gaining and maintaining power through an election in Ghana requires substantial financial resources, and this encourages corruption. A report by the National Democratic Institute concluded that political-party financing in Africa threatens political stability, because business interests and wealthy individuals engage in politics as a means to access contracts. $^{415}$ The study found a prevalent perception in Ghana that the high cost of campaigns leads politicians to ñretrieve their investmentsò should they obtain power.

Parties require financing in election and non-election years for events, congresses and rallies, media outreach, administration and overhead costs, as well as transportation. Parties also hold congresses midway between national elections to elect local, regional and national executives, creating high costs for the parties and the competing individuals. ñVote buyingò adds to this expense, particularly in a system characterized by patronage. Individual candidates in Ghana ranked vote buying as their second-largest campaign expense (after transportation). ${ }^{416}$ Presidential campaigns demand the highest financial input. .

The estimated cost of an individual presidential campaign, based on interviews with leading members of three different political parties, is USD 50,000,000. Campaign

\footnotetext{
415 Denise Baer and Bryan Shari, "Money in Politics: A Study of Party Financing Practices in 22 Countries," (Washington, D.C.: National Democratic Institute for International Affairs, 2005). 416 Ibid.
} 
costs for seats in Parliament also carry substantial costs. These figures appear high in the context of a relatively small national GDP of USD 15.2 billion and an average gross national income of USD 590. ${ }^{417}$ An estimate across two major parties and six minor parties brings the total to around USD 200,000,000. The number of voters registered in 2008 was $12,472,758,{ }^{418}$ making the per-voter cost of elections around USD 16, which compares to and even exceeds per-capita campaign costs in some advanced countries.

Neither the 1992 Constitution, Article 55, nor the Political Parties Act 2000 (Act 574) limit donations, cash or in-kind gifts by a citizen or Ghanaian-owned business to a political party. The only limitation is that non-citizens are barred from contributing directly or indirectly to a political party. The Political Parties Act (Act 574), Section 13, requires the declaration of revenues and expenditures by political parties, which should then be published. However, the political parties repeatedly fail to submit their reports to the Electoral Commission and no sanctions or penalties stipulated by law are applied. Indeed, the failure of Ghana to adhere to the legal framework on party financing contributes to the countryôs low score on the Global Integrity Report, which in 2009 noted that ñexcess campaign expenditures by the two major political parties sometimes give rise to speculations on their sources of funding..$^{419}$ Historically, the ruling class used the state as a direct means of accumulation and party financing, particularly under the

${ }^{417}$ Ghana at a Glance, 2007 (Washington, D.C.: The World Bank, 2008).

${ }^{418}$ G.N.A., "Voter Turnout Drops in Election," December 10, 2008. Accessed December 10, 2008 at: http://www.ghanaweb.com/GhanaHomePage/NewsArchive/artikel.php?ID=154414

${ }^{419}$ Global Integrity, "Global Integrity Scorecard: Ghana 2009," (Capetown: Global Integrity: 2009), 43. Accessed at: http://report.globalintegrity.org/reportPDFS/2009/Ghana.pdf 
one-party state. Increasingly however, leading members of parties, enabled by state institutions, turn to land and land-based natural resources to acquire financing. Factional Accumulation: Maintaining Power and Building Personal Wealth

The PNDC sought to prevent accumulation by the rival faction of the ruling class, but democracy led to a stark change in strategy; both ruling-class factions sought wealth to pursue and hold power. They used state and non-state resources to accumulate this wealth, facilitated by the ñshadowò or ñhizomeònetworks described in the first two chapters. It is important to note that it is difficult to provide precise figures and examples of these actions because of the lack of investigations by security services since 1992. The Attorney Generalôs office has prosecuted very few cases of corruption and those mostly fell under the nebulous ñcausing loss to the stateòcharge. Numerous media stories, particularly exposés on corruption that follow each change of party in power, remain unsubstantiated. Studies in public perception of officials provide an acceptable substitute for specific cases. Aidooôs survey of voters in Ghana found that 56.9\% thought officials awarded public contracts to ñfavoredò contractors. ${ }^{420}$ Surveys conducted in 2006 by the non-governmental organizations Center for Democracy and Development and the Ghana Integrity Initiative also suggest increased perception of corruption in recent years. More than half of the Ghanaians polled believed the presidency is corrupt; 60 per cent believe corruption has worsened; and 82 per cent of public officials believe corruption to be more prevalent today than it was only three years prior to the survey. ${ }^{421}$ A Ghanaian scholar

\footnotetext{
${ }^{420}$ Aidoo, "Political Involvement in a Democratizing Neo-Patrimonial Polity: The Case of Ghana - 1992$2000, " 30$.

${ }^{421}$ Ghana Integrity Initiative, ñGhanaôs CPI Score Worsens, ò GII Alert, no. 12 (December 2006).
} 
highlighted the fact that the state has undertaken no effective reforms to address corruption, noting that public officialsôasset declarations remain secret and inaccessible to the public. $^{422}$

Holding power is the most direct way for the ruling class to accumulate resources and to ensure that party clients accumulate wealth to be able to donate money to the party. At the national level, the dominant faction of the ruling class uses its control over the state to manipulate state contracts and procurements. Members of the faction and its clients get preferential access to infrastructural and construction supply contracts. This is important for accumulating financial resources for periods both in and out of power. Notably, the equipment purchased to initially fulfill contracts in Ghana enabled the factionôs members to operate in neighboring countries when out of power in Ghana. For example, construction companies obtained contracts to build roads and other infrastructure in near-by Liberia and Nigeria, then used road graders and paving machines originally purchased for contracts on feeder roads and drainage systems in Ghana. This ensures that the contractors continue to provide donations to the parties regardless of who holds power. Procurement awards to supply goods and services to the stateôs ministries, departments and agencies offer rapid accumulation. For instance, contracts to supply crude oil to the national oil refinery offer high profits. In addition, the faction in power provides its members and clients with lucrative consulting contracts. Professionals and advisors sometimes carry multiple contracts simultaneously across different government ministries, departments, and agencies.. The state also may pressure a donor agency to

\footnotetext{
${ }^{422}$ Baffuor Agyeman-Duah, Curbing Corruption and Improving Economic Governance: The Case of
} Ghana (Accra: Center for Democracy and Development, not dated). 
contract a favored candidate or company. At the same time, the state provides senior members of government bodies, including Parliamentarians, with housing. In many cases, the state also covers for the cost of utilities and domestic household staff. Many appointees also benefit from cars and fuel provided by the state; cars can be purchased by government officials as the end of service at reduced prices. In this way, control over the central state enables direct means for accumulation.

A similar process of accumulation occurs at the level of the district assemblies. Districts provide contracts for local business, such as building schools, roads, gutters and markets. State power also provides forms of income shared by the ruling class and subaltern classes. For instance, public toilets provide one source of income for those holding power at the regional and district level, to such an extent that the struggle to take over toilets after a change in party in power has become protracted and violent. ${ }^{423}$ Appointments to the management of state-owned rural banks also enables access to capital at the local level, often with little or no recourse in cases of default.

Accumulation also takes place outside the state, though state power is often used to facilitate the process. This can occur through access to state institutions to support a business or through protection from police and courts that might attempt to intervene in a questionable enterprise. An example of the former is that state-owned banks often provide members of the ruling class with loans to build businesses, such as hotels, carrental companies or hauling companies that will continue to operate during periods in which they are out of power. The latter strategy is exemplified by the provision of

${ }^{423}$ Numerous cases exist, but the Alajo case exemplifies the protracted and violent nature of the disputes; see Jessica Amponsah, "Clash over Alajo Toilet," Daily Guide, 22 January 2010, 1. 
protection from prosecution for drug trafficking or hiring armed guards to harass occupants of lands, both growing problems in Ghana.

The aim of using state power to help small business in order to gain support from subaltern classes is not currently evident. The trend in agriculture also appears to favor large-scale farms, benefiting those who can access capital and negotiate supply contracts. Now, providing jobs for supporters during the time in power seems to be the preferred strategy to gain popular support. The number of unskilled employees in the MDAs surged after the 2000 election. ${ }^{424}$ The ruling-class faction in power then formalized the system of providing jobs for supporters with the National Youth Employment Programme, which the subsequent government ñreformed,ò adding its own supporters to the scheme after 2008. A member of a political party summed up his expectations: corruption should ñtrickle downò from the Ministers of State to ordinary party members. ${ }^{425}$

Electoral democracy also shaped the nature of accumulation by imposing a time limit on ruling-class factions to accumulate wealth through the state. Ghanâ̂ four-year terms created a sense of urgency amongst both factions of the ruling class to accumulate money rapidly to finance the next election. This has encouraged wealth creation through short-term contracts, procurements and projects, as well as through trading ventures and building homes for rental income, rather than via investment in long-term productive enterprise. Regardless of the means, members of the ruling-class factions increasingly view securing an income outside the state as critical to political and personal survival.

\footnotetext{
${ }^{424}$ Senior Official, Head of the Office of the Civil Service, personal communications, Accra, 2008.

${ }^{425}$ Driver, National Democratic Congress, personal communications, Accra, 1996.
} 
The factional nature of the ruling class shapes the process of accumulation, because it leads to clashes over resources as each faction seeks to accumulate wealth. Simultaneously, each faction attempts to accumulate and prevent the other faction from accumulating wealth. More specifically, the faction in control of the state attempts to prevent the rival from accessing lucrative contracts and consultancies, and from accessing special assistance from state institutions through informal networks. The change from the pre-Constitution, pre-1992 era is that the dominant faction of the ruling class cannot rely on the security forces of the state to prevent rivals from accumulating assets, as this would jeopardize Ghanaôs international reputation as a democracy and endanger aid inflows.

The description of the importance of accumulation to gaining and maintaining power, and the general means through which the process has worked since 1992, enables us to locate the changing importance of land in politics. In particular, the new political strategies that emerged with electoral democracy contributed to a growth of demand for land by the Ghanaian ruling class. Following democratization, the level of finances sought for elections and personal wealth created an interest in exploitation of land and land-based resources. As Diamond describes it, ownership of land provides a security of social place for the bourgeoisie that aspires to international standards of living. ${ }^{426}$ Beyond that, land also provides a factional ruling class with assets that transcend the period in power.

\footnotetext{
${ }^{426}$ Larry Diamond, "Class Formation in the Swollen African State," Journal of Modern African Studies 25, no. 4 (1987); Amponsah, "Clash over Alajo Toilet."
} 
The Role of Land in đoliticalôAccumulation

The ruling class used its power to accumulate land both through direct access to state power, and, to a lesser extent, through the general land market when it was out of power. Presidential appointees, as well as public and civil servants, used their positions to gain preferential access to purchase public lands, in particular. The most widely discussed example of this is in the Cantonment, Ridge and Airport Residential areas of Accra. In 1998, the government of Ghana adopted a policy to divest itself of prime public lands to increase housing density. Many officials purchased the plots at below the pro-rated value set by the Lands Valuation Board and even below the price quoted by the bidders. ${ }^{427}$ Some officials purchased the plots and then resold them at high profit. The 2009 Transitional Report noted that ñcertain personsò had ñcheap access to plotsò under the policy, naming 35 officials. It also questioned the suspension and delay of a bidding process related to development of those lands. ${ }^{428}$ Subsequently, the government of Ghana published a list of properties and individuals of the outgoing government to be investigated. The Transitional Report cites several more examples of public land being transferred to private individuals at below-market rates and even on a ñprotocolò process, for which no payment was required. The Transitional Report reveals the most visible cases of use of political office to obtain valuable public lands, though more examples exist.

At the local level, district assemblies across Ghana engaged in the acquisition of land or the occupation without acquisition of land, often in alliance with the traditional

\footnotetext{
427 Transfer of Executive Assets Committee, ed., "Transition Report," (Accra: Republic of Ghana, 2009).

428 Transfer of Executive Assets Committee, "Transition Report."
} 
aristocracy. The district then mandated land use, and, in practice, often used land to build residences for district chief executives and/or other officials. However, land has also been sold to private individuals of the ruling-class faction in power as freehold property. The 2009 Transitional Report expressed concern over the delayed payment of compensation by the state to the customary owners, non-utilization of acquired land, encroachment on acquired sites by non-state actors, and change of the use of the sites against the original purpose of the acquisition. ${ }^{429}$ Again, the 2009 Transition Report notes that Ministers of State allocated flats of the decentralized Affordable Housing Scheme to non-public servants and ñsuspected relativesò in several districts, despite the schemeôs objective of providing housing for middle and junior public servants. ${ }^{430}$

Members of the ruling class also use the state indirectly to acquire land or ensure control over land by favored estate developers. Developers gain through various means from their proximity to those in state power. First, state officials assist favored real estate developers to obtain land or to ensure that infrastructure is built in areas acquired by that developer. Second, the justice system tends to rule in favor of members of the ruling faction. The Transitional Provisions, Part III, Article 7, dismantled the tribunals that had heard contentious land cases, following the completion of cases under review as of 1992. Since that time, one land litigation expert argued, the courts have continually made inroads in undermining stool and clan rights over communal land in their judgments. ${ }^{431}$ Judges at the appeal level continually delays the cases, and judges move cases between

\footnotetext{
${ }^{429}$ Ibid., 84.

${ }^{430}$ Transfer of Executive Assets Committee, "Transition Report," 38-9.

${ }^{431}$ Attorney, personal communication, Accra, 2006.
} 
courts and cite questions over jurisdiction. In greater Accra, The Ga-Adangme Council sued the government of Ghana to regain control over three high-value properties in the capital city valued at over USD 50 million. The judge found in the stateô favor in all three cases. Members of the ruling-class faction in power have interests in these developments. The state transferred a high-value residential property to the Chief Justice shortly after the third judgment against the Ga-Adangme Council. In general, a public survey by the Center for Democracy and Development found that more than $50 \%$ of Ghanaians believed the courts to be corrupt, a perception deepened by the acquisition of a public plot of land at below-market rates by Chief Justice Georgina Wood. ${ }^{432}$

Third, officials place pressure on the police and courts to release and refrain from prosecuting land guards. Complainants often testify that police have released land guards following phone calls from senior officials. In one case, a regional police commander had a personal relationship with a land-guard organizer and directly ordered his release. ${ }^{433}$ A high-ranking police official confirmed that in some areas where members of the ruling party are involved in high-level land speculation, land guards who have been apprehended by the police are released before they are charged and no entries are made in the police records. ${ }^{434} \mathrm{He}$ also noted that the practice had frustrated attempts at reducing armed robbery, as many land guards double as armed robbers once they are provided with a weapon and training.

\footnotetext{
432 Transfer of Executive Assets Committee, "Transition Report," 34.

${ }^{433}$ Senior official, Ghana Police Service, personal communication, Accra, 2007. The ACP was later investigated for his role in the disappearance of tons of cocaine from police custody, but was eventually reinstated pending completion of the investigation.

${ }^{434}$ Senior official of police, personal communication, 2008.
} 
Fourth, members of the ruling-class factions also assist clients in obtaining land demarcated for public development. School lands provide one example. In a peri-urban Accra area, a high-level government officialôs wife built a private school on a plot demarcated for a public school; after construction, no land remained upon which to provide a public school for local children. In other cases, individuals and developers acquired land and built between school buildings. For instance, a developer constructed buildings between a secondary schoolôs dormitory and administration block in New Aplaku in the Ga South District. Local authorities did not intervene. ${ }^{435}$

Members of the ruling-class factions benefit in other ways, as well. Real estate companies donate money to the allied political party during elections and congresses. Developers also provide houses for party members to reside in during years out of office. Sympathetic chiefs offer land to defray the loss of access to state-fed accumulation in the ruling partyôs out-of-power periods by transferring titled land temporarily as loan collateral for business, travel, school fees and, of course, electoral campaigns. Land thereby creates a ñsafety netò for the ruling class in the times during which they are out of power.

The above information provides an overview, though not an exhaustive one, of the means through which members of the ruling-class factions use land for accumulation, in part to promote their political survival. The accumulation of land through the state also occurred under the NRC/SMC, as described in Chapter 3, followed by a decline during the early to mid-1980s. But, the scale of accumulation grew substantially after 1992, as

435 Emmanuel Bonney, "Encroached School Lands to Be Reclaimed: Ministry Assures," Daily Graphic, 25 January 2010, 1. 
the intense demand for land for accumulation by the ruling class shifted that land away from its use as an instrument to gain subaltern support. Also, the ruling class used land for more direct party activities than it had in the past. The change in strategy to patronage and the increased importance of accumulating wealth for political survival with democratization required a third strategy. The dismantling of the coercive force of the state became the element most critical to the process of gaining and maintaining power under the new electoral dispensation. This part of the strategy is discussed in the next section.

\section{Section 3. State Coercion and the Democratic Transition: Instruments}

\section{of Institutional Weakness}

In Ghana, coercion has been a key element in the ruling-class strategy to gain and retain power as well as ensure that the favored ruling-class faction accumulates wealth and the rival faction is excluded. How did the transition to democratic rule shape the role for coercion in the ruling-class strategy? This question is important specifically because democracy is expected to curtail the use of state coercion for parochial interests and to establish security institutions protecting its constitutional norms. How does the African ruling class operationalize its strategy for factional power and accumulation within such a context?

Democratic reformers in Ghana, predominantly though not exclusively from the rival ruling-class faction, demanded that the ruling party complete the democratic transition inaugurated with the 1992 election. More specifically, they sought institutional 
reform that would eliminate the use of arbitrary power by state coercive institutions and create greater public accountability of the security services. ${ }^{436}$ The ruling-class factions appeared to reach some consensus that those occupying the government executive should not use state coercion to oppress or suppress rivals, to overturn constitutional rule, or to intervene in the accumulation of wealth. As such, intelligence and security institutions underwent reforms, albeit limited. However, the outcome had unexpected results, to which I turn my attention now.

\section{Reforming the Coercive Arm of the State}

The 1996 Intelligence and Security Service Act (Act 526) stands out as one of the first and most significant reforms of the security sector in Ghana, in addition to the 1992 Constitution. The act nominally sought to regulate the activities of security and intelligence agencies in the country. The institutional reforms granted Parliament control of regulatory and operational oversight of intelligence agencies, including appointments, funding, and annual reporting on operations. ${ }^{437}$ Parliament also formally acquired control over the arms trade and regulation of arms and ammunition within the country. ${ }^{438}$

Ultimately, the introduction of the Constitution and Act 526 fell short of bringing about real reform in security. In fact, changes made during the transition to electoral democracy ï in particular, the dismantling of the ñrevolutionary bodiesòï seemed to broaden the opportunity for instrumental use of state institutions for accumulation by the

\footnotetext{
${ }^{436}$ Hutchful, "Pulling Back from the Brink: Ghana's Experience."

${ }^{437}$ Ibid.

${ }^{438}$ C. E. Agboton-Johnson, L. Adedeji and L. Mazal. ñSmall Arms Control in Ghana, Nigeria and Senegal,ò West Africa Series, No. 2 (English) (London: International Alert, 2004).
} 
ruling class. A brief discussion below of changes made with regard to specific security institutions and the consequences of those reforms highlights this point.

\section{The Ghana Police Service}

The police service became the primary body to ensure law and order with the transition to democracy, after years of military dominance in security. Parliament gained greater control over the police service, as well. Parliament became the sole authority to raise a police force under the 1992 Constitution. In addition, the Parliamentary Select Committee on Defence and Interior, as well as the standing committees on public accounts and finance, provide mechanisms for oversight of Police Service activities and spending. The 1970 Police Service Act (Act 350) that continued to stand after 1992 also stated that the police service is accountable to the Minister of the Interior and Parliament.

The executive lost little control over the Police Service with the transition to democracy. The 1992 Constitution, Article 202 (3), vested in the President the power to appoint the Inspector General of Police and all persons ño hold or to act in an office in the Police Service.òThe Constitution also granted the Vice President chairmanship of the Police Council and gave the President the right to appoint the majority of members on the Police Council, a body central to the procurement process. The constitutional provisions enabled the dominant ruling-class faction to exert control over the police service through appointments and dismissals, often along party lines.

The police service deteriorated continually in the years after 1992, despite constitutional reform and increased democratic oversight. Indeed, Aning and Lartey point 
out that Parliament has never demanded compliance or exercised such oversight. ${ }^{439}$ The executive submitted only one report to Parliament between 1996 and 2008, despite the fact that annual reports were to be mandatory. Moreover, the police service under ñdemocratic governanceò failed to meet the needs of the populace. Police service numbers fell to 14,412 between 1999 and 2001, an estimated drop of 23,000 police personnel, ${ }^{440}$ and the composition of employed police personnel became increasingly top heavy. ${ }^{441}$ Recruitment standards also declined. The Criminal Investigations Division relied on forensic laboratories equipped during colonialism, some of which dated to the 1920 s. $^{442}$ The state did not expand police services to new communities as the peri-urban areas and district capitals developed rapidly. In addition, new infrastructure and increased vehicle imports allowed greater road travel, but the police service failed to patrol the highways; armed frnighwaymenò became a persistent threat to travelers. The U.S. State Department noted the elevated threat on its travel alert information for Ghana.

The failures of the police service became increasingly apparent, but successive governments neglected the recommendations of the commissions of inquiry they initiated. The government did not respond to the 1997 Archer Report until May 1999, and then it failed to implement the reportô recommendations. A later 2001 government of Ghana commission to investigate lapses that led to the Accra Stadium Disaster ${ }^{443}$ charged

\footnotetext{
${ }^{439}$ Ernest Lartey and Kwesi Aning, "Parliamentary Oversight of the Security Sectors: Lessons from Ghana," in Parliamentary Oversight of the Security Sector in West Africa: Security Sector Reform as Conflict Prevention? (New York: Center on International Cooperation, New York University, 2009).

440 Aning, "An Overview of the Ghana Police Service."

${ }^{441}$ Hutchful, "Pulling Back from the Brink: Ghana's Experience."

${ }^{442}$ Security expert in the diplomatic corps, personal communication, Accra, October 2009.

${ }^{443}$ Police fired tear gas into a stadium of spectators at a football match on May 9, 2001 in Accra. The resulting stampede led to 126 deaths.
} 
several police officers, but did not address substantive institutional weaknesses. The government argued that it had insufficient financial capacity to reform the service, but security experts responded that many recommendations required no financial outlay; instead, they blamed inadequate ñpolitical willò to strengthen the police. ${ }^{444}$

Various reports seemed to suggest official acceptance of increasing commercialization of security forces to compensate for police failures, as did the governmentô licensing of private security companies after 1992. Moreover, the privatization of police duties became increasingly common. So-called ñmonkey duty,ò the engagement of police officers for private pay, soared, often under the direction of police commanders. ${ }^{445}$ This private use of public coercion, in turn, further undermined the authority of the police service. Briefly stated, democratic reforms did not lead to improvement in maintenance of law and order by a civilian-controlled police force; they enabled those with resources to use state force and authority for private ends instead.

\section{Military: The Ghana Armed Forces}

The changes in the Ghana Armed Forces mirrored those taking place in the police service. The Constitution of the Fourth Republic reinstated the civil command of earlier constitutional regimes. As in the case of the Police Council, Article 211 of the 1992 Constitution gave the Vice President chairmanship of the Armed Forces Council, a position with influence over contracts and procurements. The Constitution also granted

\footnotetext{
${ }^{444}$ Aning, "An Overview of the Ghana Police Service."; Hutchful, "Pulling Back from the Brink: Ghana's Experience."

445 Albert K. Salia, "No More 'Monkey Duties'," Daily Graphic, 26 January 2010, 31.
} 
the President control over the appointment of officers and commissions. This gave the executive extensive control over the Armed Forces. Parliament also had the ability to hold the Armed Forces accountable through use of standing and select committees.

Parliament continually failed to utilize its role as overseer of the military, even in the area of spending. Parliament has tended to vote according to the demands of the executive and along party lines, according to security scholar Aning. ${ }^{446}$ The emphasis on the military for domestic security declined initially, and defense spending decreased from 137 million US dollars in 1998 to 121 million US dollars in 1999. The budgetary allocation for defense also declined from 57 million US dollars in 1999 to 45 million US dollars in $2000 .{ }^{447}$ However, spending for external military missions gained support. In 2003, parliament approved USD 55 million for acquisition of equipment and helicopters for UN peacekeeping operations in the Democratic Republic of Congo. It is interesting to note that the original cost estimate was less than half that amount, at USD $19,645,600 .^{448}$ The lack of special staff and training for the parliamentary committees and loss of institutional memory resulting from electoral turnover of Members of Parliament have been cited as a possible reason for the inadequate oversight, ${ }^{449}$ though this cannot adequately explain the glaring gaps in oversight of military spending and activities.

Clearly, patronage politics spilled over into the military after 1992, as it had under the NRC during Acheampongố authoritarian rule. For instance, following each change in ruling party in power, the dominant ruling-class faction reassigned senior military

\footnotetext{
446 Aning, "Parliamentary Oversight of the Security Sectors: Lessons from Ghana."

447 Ibid.

${ }^{448}$ Lartey and Aning, "Parliamentary Oversight of the Security Sectors: Lessons from Ghana."

449 Ibid.
} 
officers suspected to be sympathetic with the outgoing faction to undesirable posts. Political pressure led to other resignations after each election. In the wake of the 2000 election, the new President of Ghana appointed his brother, a career medical doctor, to the position of Defense Minister, despite the brotherô lack of knowledge about the cabinet department to which heâd been assigned. Such appointments contributed to the politicization of the military.

Again, the democratization of oversight of the Armed Forces did not lead to improvement in service. Like the police, military personnel began to engage in private security ñ contracts, ò while they were in uniform and utilizing military vehicles, equipment and weapons. The involvement of the police and the military in armed exchanges over land and natural resources enabled those with access to financial and state power to subdue local populations and gain greater control.

\section{Dismantling the revolutionary bodies}

The ñrevolutionary bodiesò had acted as mechanisms for accountability in the police service and to a lesser extent in the military during the PNDC period, reporting perceived conflicts and official corruption to the national security bodies. However, opponents of the PNDC (and later NDC) argued that the CDR had been a tool for human rights abuses, and, therefore, that it should not be allowed to continue as a state institution under democracy. Members of the dominant ruling faction did not reject demands to terminate the institution, perhaps because they were also threatened by the influence of 
the CDR among subaltern classes and the investigative capacity of the NIC. As such, dismantling the revolutionary bodies began soon after the democratization.

While at the time of the 1992 election, the CDR continued to function in cooperation with district government structures, and as part of the coercive apparatus, they were omitted in the 1992 Constitution and the revised Local Government Act 1993 (Act 462). The national security institutions also began to ignore reports submitted by district organizing assistants (OA), according to those interviewed. The Confiscated Assets Committee began to return properties to former owners as part of democratic reconciliation, and CDRs in state-owned buildings acquired through confiscations closed. The CDR central office at the seat of government also closed. Most CDR offices had ceased to operate by the 1996 election. The CDRs responded to the changes by converting to a non-governmental organization under the name Association of the Committees for the Defense of the Revolution (ACDR). The dismantling of the CDR became more aggressive after the party-in-power changeover in 2000. Functionaries of the new government raided the remaining CDR offices, seizing and burning files. Former cadres of the CDR all noted that they felt trepidation about discussing the official activities that they had participated in prior to 1992, and many hid remaining files following the 2000 election.

The state formed no institution in the wake of the democratization exercise to replace the CDR in maintaining law and order and in arbitrating disputes at the local level. Parliament briefly discussed the ñvacuumò created by the dissolution of the CDRs after 1992, following violence between football fans in Ghana and bordering La Cote dô 
Ivoire on $1^{\text {st }}$ November 1993. Parliamentarians commented on the problems created by the absence of the CDR at the border crossings and on the need to create stations for the police service where the CDRs used to monitor the borders. ${ }^{450}$ In addition, no subsequent institution used the Head of Family Accountability Act, which the CDR had used successfully to manage communally owned property, to arbitrate or argue land or landbased resource cases following the dismantling of the CDR. Nor did the state seek to replace the position the CDR had held in the district-level security body. Ultimately, those in control of the state never filled the gaps created by the dismantling of the CDR.

\section{Investigative Intelligence Bodies: Transformation of the NIC into the SFO}

The National Investigations Committee also continued its active pursuit of ongoing economic fraud cases after 1992, but it began to close operations in 1993 and 1994. This followed the Transitional Provisions, Part IV, Article 12, which ordered that any cases pending before the NIC and the Office of the Revenue Commissioners could not be completed until the reports were submitted or until the institution was dissolved in law.

Unlike the CDR institution, former public servants of NIC insisted that a body be established to address economic fraud, as had been done in countries such as the United Kingdom. ${ }^{451}$ The Parliament gazetted the Serious Fraud Office Bill in July 1993, and then began readings and debates in October of the same year. The factions of the ruling class

\footnotetext{
${ }^{450}$ Parliament of the Republic of Ghana, "The Parliament of Ghana, Third Meeting," Parliamentary Debates (Accra: Ghana Publishing Corporation, 1993).

${ }^{451}$ It is noteworthy that the government of U.K. studied Ghanấ National Investigation Committee in setting up its Serious Fraud Office.
} 
debated the creation of the SFO more than any other bill before the Parliament in the transition to democracy. The party in power invited the opposition parties to Parliament to debate the bill, as those parties had boycotted the Parliamentary elections and had no representation in Parliament. The opponents to the bill argued that the newly elected executive would use the SFO to abuse citizens and seize property arbitrarily. ${ }^{452}$ The ruling-class faction in power responded with a massive public-education and propaganda exercise on the bill, ${ }^{453}$ noting a rise in embezzlement and fraud and enumerating the

452 "This Business of Serious Fraud," Ghanaian Chronicle, September 27 - October 2, 1993, 3.; "The Fraudulent Serious Fraud Bill," Ghanaian Chronicle, September 27 - October 2, 1993, 3.;"The Serious Fraud Office Bill," Ghanaian Chronicle, October 17, 1993, 6-7.; "Throw the SFO Bill Somewhere!," Ghanaian Chronicle, October 18-24, 1993, 5.; "Blows at the Fraud Bill Debate," Ghanaian Chronicle, November 1-7, 1993, 7.; "Why the Fraud Bill Is Good," Ghanaian Chronicle, November 11, 1993, 5.; "The Dangers in Historical Perspective of the SFO Bill, Part I," Ghanaian Chronicle, November 22-25, 1993, 3.; "The US-Ghana Debate on the Fraud Bill," Ghanaian Chronicle, November 29 - December 1, 1993, 6-7.; "The Dangers in Historical Perspective of the SFO Bill, Part II," Ghanaian Chronicle, November 29 December 1, 1993, 3.; "The Dangers in Historical Perspective of the SFO Bill, Part III," Ghanaian Chronicle, December 6-8, 1993, 3.; "Govt to Seize Assets," Independent, August 11-17, 1993, 1, 12.; "The Bill That Must Be Reviewed," Independent, August 18-24, 1993, 6-7.; "Danger Ahead!," Independent, August 25-31, 1993, 1.; "Reject the SFO Bill," Independent, September 29 - October 5, 1993, 4.; "Scrap the SFO Bill," Independent, October 13-19, 1993, 2; E. C. Taylor, "The SFO Bill Is Unconstitutional," Independent, October 13-19, 1993, 2.; "Council of State Rejects the SFO Bill," Independent, October 27 November 2, 1993, 1.; "The SFO Bill - Those in Favour," Independent, October 27 -November 2, 1993, 1.; "Morality and the SFO Bill," Independent, November 17-23, 1993, 6-7.; "The SFO Bill: A Layman's Impressions," Independent, November 24-30, 1993, 6-7.; "Why Are We Rushing the SFO Bill?," Independent, December 22-28, 1993, 4.

${ }^{453}$ The Daily Graphic printed not fewer than 24 articles between October and the end of December when the President signed the bill. See, for examples: Sammy Oppong, "The Serious Fraud Office," People's Daily Graphic, October 4, 1993, 5.; Lloyd Evans, "Observations on the Fraud Bill," People's Daily Graphic, October 6, 1993, 5.; "SFO Bill Printed," People's Daily Graphic, October 8, 1993, 5, 7.; "The SFO," People's Daily Graphic, October 11, 1993, 5.; "Lecture on Serious Fraud Bill," People's Daily Graphic, October 21, 1993, 3.; "Fraud Bill - GBA Presents," People's Daily Graphic, October 25, 1993, 3.; "Views on the SFO Bill: A Bill for All?," People's Daily Graphic, November 3, 1993, 5.; "Dialogue on the SFO Bill," People's Daily Graphic, November 5, 1993, 8-9.; Tony Aidoo, "Still on the SFO Bill," People's Daily Graphic, November 11, 1993, 7.; "This Fraud Song," People's Daily Graphic, November 19, 1993, 7.; Daniel Larbi, "The Constitution, Economy and Fraud Offic," People's Daily Graphic, November 27, 1993, 5.; "Report on Fraud Bill to Be Laid before House," People's Daily Graphic, December 4, 1993, 3.; "Parliament Defers Laying of Bill," People's Daily Graphic, December 8, 1993, 3.; "'Re-Appraise Clauses of Fraud Bill'," People's Daily Graphic, December 9, 1993, 3.; "Serious Fraud Office Bill Is a Necessity," People's Daily Graphic, December 16, 1993, 3.;; D. Fynn, "Withdraw Serious Fraud Office Bill," People's Daily Graphic, December17, 3.; D. Fynn, "Fraud Office Goes through Second Reading," People's Daily Graphic, December 18, 1993, 3.; "Allow Sufficient Public Debate," People's Daily Graphic, December 20, 
institutional requirements needed to arrest the problem. ${ }^{454}$ The coverage of the debate over the SFO in the media remains unprecedented.

Parliament eventually passed an amended version of the SFO Bill, which President Rawlings quickly signed. The state then dissolved the National Investigations Committee before the new Serious Fraud Office was established and resourced.

Moreover, the SFO that resulted had substantially decreased investigative power and heightened partisan oversight compared to NIC. Investigative officers would attempt to build cases only to be blocked by ministers of state with greater authority, who would use such methods as stalling the release of the budget to prevent investigations. Indeed, the SFO had little of the authority and independence of the preceding NIC, and it has produced few substantial cases of corruption by officials.

\section{Regional and District-Level Security Institutions}

The Security and Intelligence Agencies Act (526) of 1996 also established regional and district security councils responsible for ñmplementing government policies on security of the state and attendant issues on or relating to the internal and external security of the State and to provide for related matters. $0^{455}$ The act sought to decentralize conflict prevention, management and resolution, from national to regional and district levels. However, the composition of such bodies undermined the effectiveness of the

1993, 3.; "Fraud Bill Goes through Consideration Stage," People's Daily Graphic, December 22, 1993, 3.; "House Passes Fraud Bill," People's Daily Graphic, December 23, 1993, 1.

${ }^{454}$ Parliament of the Republic of Ghana, "Parliamentary Debates, Second Meeting," Parliamentary Debates (Accra: Ghana Publishing Corporation, 1994).

${ }^{455}$ Cited by Lartey and Aning, "Parliamentary Oversight of the Security Sectors: Lessons from Ghana," 1920. 
institutions. The DCE is in effect the head of the DISEC and the regional minister of REGSEC. The Office of the President appoints the DCEs and the regional ministers. In practice, therefore, the dominant faction of the ruling class appoints heads of the national, regional and district-level security institutions, and the members of those security institutions report to those who have appointed them. Through these appointments, parochial interests can be pursued and threats to security ignored according to personal and party interests. This composition of the decentralized security apparatus has deepened the partisan nature of local conflicts and has favored local power brokers. It is not surprising that the composition of these regional and local security bodies also creates the opportunity for accumulation and extends the scope for creating and reproducing patronage relationships.

Intended and Unintended Consequences of ñDemocratizingò Security: The decline of security and the increased private use of coercion

Scholars and security experts have noted that a relationship appears to exist between democratic transitions and decreased security, ${ }^{456}$ though these experts have identified a correlation but not the causal link between democratization and security decline. For its part, the UN Office on Drugs and Crime expressed alarm over the ñspread of violence in West Africa [that] occurred simultaneously with the growth of

\footnotetext{
${ }^{456}$ See for instance, Bruce Magnusson, "Democratization and Domestic Insecurity: Navigating the Transition in Benin," Comparative Politics 33, no. 2 (2001).
} 
democracy. ${ }^{457}$ Ghana was no exception to this proliferation of violence. An overview of the figures provides an adequate illustration. Crime levels increased between 1991 and 1996: murder increased by 70 per cent, assault by 76 per cent, and theft and robbery nearly doubled. ${ }^{458}$ An outbreak of ethnic violence over land and traditional paramountcy in 1994 led to thousands of deaths, displaced more than 100,000 people, and resulted in massive destruction of property. ${ }^{459}$ According to Hutchful, violence was becoming ñendemicò in Ghana, while private security companies were ñflourishing. ${ }^{460}$ Armedrobbery cases went from 311 in 1999 to 777 in 2001, with 447 reported in the first eight months of 2002. ${ }^{461}$ Armed community-based watch groups began patrolling in voluntary shifts, mounting roadblocks to search vehicles and apprehending armed robbers. Commercial private security services became commonplace and were used by private citizens and industry to protect property in the absence of an effective state coercive system.

Apart from violent and property crime, official corruption is perceived to be on the rise. Surveys conducted in 2006 by the non-governmental organizations Center for Democracy and Development and the Ghana Integrity Initiative suggest that public perception of corruption has increased in recent years. Over half of Ghanaians polled believe the Presidency is corrupt, 60 per cent believe corruption has worsened, and 82 per cent of public officials believe corruption to be more prevalent today than it was only

\footnotetext{
${ }^{457}$ UNODC, ñTransnational Organized Crime in the West African Regionò(New York: United Nations, 2005).

${ }^{458}$ Appiahene-Gyamfi, ñAn Analysis of Broad Crime Trends and Patterns in Ghana.ò

${ }^{459}$ World Refugee Survey 2004 (Washington, D.C.: United States Committee for Refugees and Immigrants).

${ }^{460}$ Hutchful, ñPulling Back from the Brink.ò

${ }^{461}$ Agboton-Johnson, ñSmall Arms Control in Ghana.ò
} 
three years ago. ${ }^{462}$ A Ghanaian scholar noted that the state has taken no effective reforms to address corruption, while public official asset declarations remain secret and inaccessible to the public. ${ }^{463} \mathrm{He}$ was equally critical of the appointment of a ñácorruption czarôwith close and familial tiesò, referring to the establishment of an Office of Accountability at the Office of the President under the NPP; ${ }^{464}$ the appointed head of the zero-tolerance policy on corruption was the wife of a senior policy advisor and mother of a close presidential aide.

The vast increase in the flow of weapons into Ghana and in the domestic manufacture of weapons highlights the threat of a weakened security sector. International Alert warned of a flood of weapons into Ghana from neighboring conflicts in the region and ñleakagesò from the state armory onto the black market. ${ }^{465}$ Largely uncontrolled licensed importation also contributes to the proliferation of weapons in the country. A 2003 report found five major licensed companies importing an average of 20,000 firearms annually. ${ }^{466}$ At the same time, state officials have turned away from licensing importers, a process that could enable greater scrutiny, and have begun to grant approval to individuals to import weaponry. ${ }^{467}$ In any case, established procedures for importation, storage, supervision and distribution of arms and ammunition are not followed. ${ }^{468}$

Imports offer only one source for weapons. Domestic production of guns in Ghana has grown increasingly sophisticated and contributes significantly to the number

\footnotetext{
462 Ghana Integrity Initiative, "Ghana's C.P.I. Score Worsens," GII Alert, no. 12 (2006).

${ }^{463}$ Agyeman-Duah, ñCurbing Corruption and Improving Economic Governance: The Case of Ghana.ò

${ }^{464}$ Ibid.

465 Agboton-Johnson, ñSmall Arms Control in Ghana.ò

${ }^{466}$ Kwesi Aning, ñHomemade and Imported Guns,ò West Africa, 7 ï 13 July 2003, 18.

${ }^{467}$ Diplomatic official, personal communication, Accra, July 2007.

468 Agboton-Johnson, ñSmall Arms Control in Ghana.ò
} 
of weapons in the sub-region. Early projections that 35,000 to 40,000 guns were locally manufactured appears to have been underestimates, as thousands of cells throughout the country manufacture specific parts, which are then assembled by other cells that lack only the ability to produce ammunition. ${ }^{469} \mathrm{~A} \mathrm{UN}$ report cites reports that weapons made in Ghana have been retrieved across West Africa. ${ }^{470}$ International Alert has noted that the low value of Ghanâ̂s currency gives the producers a comparative advantage in the region; this encourages Ghana to become a net supplier of guns in the region. ${ }^{471}$

It is not surprising that each government since 1992 has failed to develop an effective program to stem the growing arms industry. State attempts to control production and decrease the number of weapons in circulation have been weak. A voluntary firearms collection by the police service in 2001 , which was aimed at retrieving 40,000 small arms and weapons, collected only 2,000, ${ }^{472}$ and further arms-recovery attempts in 2004 recovered only several hundred weapons. ${ }^{473}$ Government policy on firearms remains unclear, and the Arms and Ammunition Inventory Committee, which is overseen by the Parliament, continually fails to insist on accountability of the executive.

The limited examination of security lapses above suggests more than a lack of political will to strengthen security. Rather, the analysis highlights the instrumental use of the reforms made to the coercive services in the strategy to control formal and informal

\footnotetext{
${ }^{469}$ Aning, E. Kwesi. ñThe Anatomy of Ghanaô Secret Arms Industry,ò Armed and Aimless: Armed Groups, Guns and Human Security in the ECOWAS Region (Geneva: UNODC, 2005).

${ }^{470}$ UNODC, ñTransnational Organized Crime.ò

471 Agboton-Johnson, ñSmall Arms Control in Ghana.ò

${ }^{472}$ Alhaji Bah, ñMicro-disarmament in West Africa: The ECOWAS moratorium on Small Arms and Light Weapons,ò African Security Relations 13, no. 3 (2004). Others report only 1,000 weapons retrieved; see Agboton-Johnson, ñSmall Arms Control in Ghana.ò

${ }^{473}$ IRIN (United Nations Integrated Regional Information Networks) ñGhana: Bonfire of Captured Guns Launches Police Crackdown on Small Arms, ò October 29, 2004.
} 
means of accumulation and to build patronage networks. The institutions of the coercive arm of the state underwent some form of democratization, but the result was effectively the privatization of coercion. The state under democracy no longer maintained a monopoly on the use of coercion, as members of the ruling class, the traditional aristocracy and private companies effectively mobilized elements of the state security services for private ends and armed their own militias with little hindrance from the state. This private use of coercion became critical to primitive accumulation in land and landbased natural resources. How did the changes in the coercive arm of the state under an electoral democracy contribute to the shift toward greater violence in land relations? We return to the central questions of the dissertation below to understand the consequences of the shifts in strategy that followed the new electoral means of accessing power and the bitter struggle for accumulation.

\section{Section 4. Land Relations and Democratization: the Emergence of a}

\section{Violent Land Sales Market.}

The land market grew at an unprecedented rate from the 1990s onward. Disputes over land in the late 1980s and early 1990s concentrated largely around the largest urban centers, primarily Accra. Unchecked, the problem grew to be nationwide, such that by 2009, encroachment and disputes plagued most regional capitals and some district capitals. ${ }^{474}$ The Kofi Annan International Peacekeeping Training Centre, in Accra,

${ }^{474}$ GNA, r̃Residents of Zuarungu and Tongo-Beo Clash Over Land,ò January 25, 2005. Accessed at: http://www.modernghana.com/news/70742/1/residents-of-zuarungu-and-tongo-beo-clash-over-lan.html. 
assessed the capacity of the state to deal with chieftaincy and land disputes in $2005 .{ }^{475}$ The research team found low- to medium-level-intensity conflicts over land in all the regions of Ghana studied. Ultimately, the document warned that given the lack of ability by state institutions to handle the conflicts amid the proliferation of small arms in Ghana, human security was being undermined. The report further stated that more than 60,000 land-related cases were pending before the Supreme Court. Indeed, encroachment on both communal and public land had become so pervasive by 2009 that even the armed forces had lost all but two acres of the 482 acres allocated to it for military use. ${ }^{476}$ The media and public widely, but anonymously, blamed public officials. The transition to democratization paralleled this growth in land transfers and in disputes. Previous chapters have shown that historically the political strategy of the dominant ruling-class faction shaped land relations. How did the transition to electoral democracy alter land relations? How did the subaltern classes react to their changing position in land relations?

\section{Ruling Class: Factional and Personal Accumulation}

Why did the growth in a land market lead to greater, more destructive violence?

Why did democracy not lead to more secure property rights? To answer these key questions, it is necessary to re-examine how the ruling class asserted control over land. The interrelated processes of economic and political liberalization accelerated the process of commodification in the land market. After 1992, land increasingly became a means for

\footnotetext{
${ }^{475}$ Kwesi E. Aning, "Chieftancy, Land Conflicts and Conflict Resolution Mechanisms in Ghana" (Accra: Kofi Annan International Peacekeeping Training Centre, 2005).

${ }^{476}$ Emmanuel Adu-Gyamerah, "Armed Forces Recruitment Resumes: 46,124 Apply," Daily Graphic, February 5, 2010, 1.
} 
the ruling class to accumulate wealth and secure an income, at least a portion of which could be sustained outside of state power. Land and housing ceased to be issues around which the dominant faction of the ruling class sought to galvanize subaltern support, as had occurred under the PNDC. The ruling-class factions no longer had an interest in ensuring that subaltern classes could exercise control over customary land and hold the traditional aristocracy to account for land allocations and revenue. Instead, they sought to have land allocated to favored clients among their own factions. In short, land came to be a wealth-building commodity for furthering political interests.

The dominant class gained control over resources primarily through state power; thus, its ruling faction could ensure that its own people benefitted from land transactions. Officials, from the highest executive and ministerial levels to lowly civil servants, created and then continually manipulatedthe weak institutions that enabled them to appropriate land. Bureaucratic strategies included drafting but not finalizing planning documents, non-enforcement of zoning regulations, and manipulation of the cumbersome titling process. In the courts, administrators and judges slowed down cases, transferred cases repeatedly, and, ultimately, shaped court outcomes to suit the ruling class. Rulingclass factions exacerbated chieftaincy disputes as each faction aligned with chieftaincy factions. The Office of the Stool Land Administrator refused to disperse royalties collected by the institution on all titled lands to stools where chieftaincy disputes existed. National and local government institutions compulsorily acquired land, withheld compensation, and then re-sold the public lands to private individuals and commercial developers, particularly those who aligned themselves with the dominant faction of the 
ruling class. Critically, the ruling class enabled the privatization of state coercion, which only those with resources could mobilize to appropriate and defend land. The ruling-class strategy utilized the state institutions to accumulate wealth through land and land-based resources, in part to gain and retain power.

Parliament debated the issue of ñland guardismò in 1998, following media coverage of violence in one case in which the President intervened. However, Parliament did not initiate any legislation to halt the emergence of the land militias. The police service revisited the issue of land violence and formally established a unit in 2006 to address land guards. ${ }^{477}$ The unit did not accomplish the publicly stated goal, and many police officials seemed unaware of its existence. In short, the official state response to the rise of land violence remained limited and ineffective.

In most cases, the ruling-class factions responded to organized resistance to land appropriation through deploying state and private violence, or through dividing or coopting youth and other associations. For instance, the La Youth Association objected to the state constructing residential properties to be used by dignitaries attending an African Union conference in Accra on La land. The association went to the La Wireless area with customary asafo companies to protest and attempt to halt work. The police stopped the protest and dispersed the participants. Moreover, the ruling class sought to divide youth associations based on party affiliation, and then financed each factionô press conferences, media coverage, and in some cases, land-related violence. In one example, the youth split along party and ruling-class faction lines in a dispute over revenues from

${ }^{477}$ Mary Mensah, "Police Set up Land Fraud Unit," Daily Graphic, April 18, 2006, 3. 
the recreational Labadi Beach. The dominant faction in power issued a legislative instrument to give the Ghana Tourist Board (GTB) control over the recreational area. The GTB in turn began selling plots on the beach. The two youth associations engaged in a number of violent clashes. The association that eventually emerged victorious, determined by the party in power, failed to account for the revenue collected. The overlap of party/MP/DCE interests and factional disputes over land are common. The more commonly cited disputes over land of this nature include the current violence in Bawku between the Mamprusi and Kusasi, and that between the Konkomba and Nanumba that occurred in the 1990s. In these cases and in numerous others, the state failed to halt violence over land, because that would have contradicted the interests of the ruling-class factions.

Traditional Aristocracy: Constrained Reassertion of Power

The nature of the complex landholding patterns in Ghana, in which the majority of land is stool land, required that the ruling class form an alliance with chiefs and other members of the traditional aristocracy to access land. This relationship became possible through an increased role for traditional leaders in local government following the transition to democracy. The changes increased the power of the traditional aristocracy over the subaltern classes, most notably in land and land-based resources. ${ }^{478}$ In turn, the ruling-class factions aligned with members of the traditional aristocracy to access, and

\footnotetext{
${ }^{478}$ A distinction should be made between higher-ranked chiefs and customary officials, such as paramount, and those of lower, divisional and sub-divisional ranks. Many chiefs of lower ranks share similar socioeconomic indicators with the subaltern classes and do not benefit from links to state officials.
} 
prevent ruling-class rivals from accessing, the land and land-based resources. The constitutional institutions seemingly aimed to regulate the affairs of the traditional aristocracy only deepened the traditional aristocracyôs ability to allocate resources to the ruling class; it may be noted that the aristocracyấ ability to allocate land for foreign investment in mineral- resource exploitation also increased. The constitutional and legal position of chiefs following 1992 contributed to deteriorating land relations and local security.

The traditional aristocracy increasingly engaged in struggles over land and land revenues after1992. A 2005 Kofi Annan International Peacekeeping Training Centre security study found that the 1992 Constitution muddied the waters on resource use and revenue allocation. It stipulated a division of royalties, with a percentage going to the stool. However, the study points out that ñthe stoolò remained undefined. Subjects took the position that ñthe stoolò means ñthe people,ò a view that appears consistent with historical views on communal resource ownership. The traditional aristocracy, for its part, has put forward a number of arguments. Members of the traditional aristocracy argue that they hold the land in trust for their subjects and ensure that land sales benefit those subjects. They also claim that they must sell the land quickly, before the state appropriates it for public purposes without compensating them. Chiefs further point to the need for land revenue to compensate for the high cost of customary duties and palace maintenance. One chief interviewed in the greater Accra region noted that he used land revenue to pay for the electricity on a streetlight located near his palace so that his 
subjects would have light. ${ }^{479}$ The Ngleshie Alata Youth Association, whose patron is the paramount chief of James Town, argued that it ensures land is leased and not sold, that leases are 50 years rather than 99 , and that ground rents are regularly collected by the stool. ${ }^{480}$ However, few paramount or divisional chiefs bother are accountable to their subjects on land revenues or try to convince them that the revenue money is being spent to their benefit.

The traditional aristocracyôs lack of accountability tends to be ignored by the government. The state argues that problems in land relations derive from chieftaincy conflicts and says that it cannot interfere in chieftaincy affairs, despite its maintenance of a state Ministry of Chieftaincy and Culture. At the same time, high-ranking chiefs control the customary authorities who deliberate on issues of de-stoolment, including those relating to mismanagement of land and land revenues, insulating themselves from destoolment challenges. Furthermore, disputing chiefs use links with state officials to provide coercive force when they are under threat, mobilizing the police officially to prevent or disband public gatherings inimical to their interests, and mobilizing them unofficially, i.e. in off-duty operations, to defend control over resources. Finally, chiefs also use links to public officials and members of ruling-class factions to protect their armed ñetainersò from arrest and prosecution. In short, the position of dominance of the traditional aristocracy in relation to stool subjects grew with democracy, as the ruling class sought an alliance to promote patronage and accumulation. It is ironic that the paramount chiefsôstrength is being further solidified by official recognition and financial

${ }^{479}$ Divisional Ga chief, personal communication, Accra, May 2006.

${ }^{480}$ Ngleshi Alata Youth Association, personal communication, Accra, May 2006. 
support from donor agencies, such as the World Bank, to increase the capacity of chiefs to manage the social capital needed to promote pro-poor development.

\section{$\underline{\text { Subaltern Classes: Lost power, lost land and the new ñretainersò }}$}

The subaltern classes largely lost control over land during the period following the democratic transition. The constitution granted the ñraditional authority,òi.e. the traditional aristocracy, rather than the stool subjects, control over land. Stool subjects privately objected to the interpretation of their customs, but, as discussed above, they lacked a means of redress. In addition, increased emphasis on titling excluded many subalterns who lacked the resources to process land leases. ${ }^{481}$ The traditional aristocracy regained power over the lands and the land revenues with the assistance of ruling class allies.

In addition to the Constitution, the new ñustice systemò also disadvantaged the subaltern classes. First, the court system appeared to act in the interests of the dominant faction in power. For instance, the Ga-Adangbe Council engaged prominent lawyers to attempt to regain control over high-value properties in Accra. Yet the state gave a judge at the highest level a valuable public property following three judgments he made against the Ga-Adangme Council. ${ }^{482}$ Second, the traditional aristocracy formed its own courts to hear issues relating to chiefs and claims on stool lands, but the chiefs and other members

\footnotetext{
${ }^{481}$ Youth organizer, personal communication, Accra, June 2006. He pointed out that those with money could ñfast-trackò the titling process, whereas those who sought to pay only the required official fees often lost their land before the processing was finished.

${ }^{482}$ Leading member of the Ga/Adangbe Council and Council attorney, personal communication, May 2007. The three cases covered the properties of Granada Hotel, airport city land, and Bubuashie Wireless.
} 
of the traditional aristocracy controlled these institutions to such an extent that stool subjects could not use them to pursue their interests. Third, the Head of Family Accountability Act, which had provided the subaltern classes with a tool to seek redress when the traditional aristocracy abused power and mismanaged land or land revenues, was ignored after the ruling class dismantled the CDR structure. Fourth, the withdrawal of the tribunals and the CDR Committees for Arbitration meant that subaltern classes had to pursue their cases in the courts $\ddot{i}$ a course of action largely outside their reach, as they could not afford the payment of lawyers and court fees. Again, stool subjects complained privately that they could not ñafford justice.òThe ruling class instituted various initiatives for local-level arbitration, but this process was often controlled by members of the ruling class or by chiefs, and it failed to address the imbalance.

The decentralization process did not support the interests of the subaltern classes in land, despite the requirement for representation of local vulnerable groups. As discussed above, DCEs and other local officials often use their positions to acquire land; sometimes they use their power to compel acquisitions. In addition, district assemblies have not enforced adherence to planning and zoning. Rather, departments under the district assemblies grant permits that directly violate zoning, allowing for buildings in waterways and for commercial properties in residential areas. In one representative case, farmers formed an association in an attempt to prevent the local government from reclaiming land and ejecting them following the local government $\hat{Q}$ decision to re-zone the area for residential purposes. ${ }^{483}$ The residentsôassociation objected to the transfer of the land to a

${ }^{483}$ Rose Hayford Darko, "Community 21 Residents Warn Tdc," Daily Graphic, February 19, 2010, 29. 
private developer by the ñelite class, ò and farmers provided documentation that named the government officials who had benefitted from the transfer. The government responded merely to confirm that those who had been granted the land for agricultural purposes would be ejected. Local subaltern classes have been unable to hold district assemblies and DCEs accountable. Moreover, the subaltern classes lacked a means to defend their lands, as the struggle for land became more violent. Dismantling the CDR and restructuring the district and regional security institutions created a gap in representation for the subaltern classes. The private use of the police and military by the ruling class to acquire land overwhelmed the subaltern classes. Police did not investigate or pursue complaints by members of the subaltern classes about harassment and violence perpetrated by land guards; the police did not even register such complaints in station logs. ${ }^{484}$ In the example of Weija, near Accra, land guards continually harass local subaltern classes and extort money and building materials from those attempting to build in the area, despite repeated complaints to the local and regional police. ${ }^{485}$ Members of the traditional aristocracy also use the threat of ñjujuò to intimidate subjects. ${ }^{486}$

Members of the subaltern classes initially attempted to defend their lands physically as those lands began to be sold by the chiefs or clan heads. In the example of Ablekuma, the local village attempted to resist interference by two policemen on ñmonkey duties, ò eventually killing the policemen. The police service responded by burning the village and arresting nearly all the males. Ultimately, however, the subaltern

\footnotetext{
${ }^{484}$ Former regional police commander and current senior official of the Ghana Police Service, personal communication, Accra, June 2006.

${ }^{485}$ Division Ga chief, personal communications, Accra, 2006 and 2007.

${ }^{486}$ Community leader, Bukom, personal communications, Accra, May 2006.
} 
classes cannot access weapons equal to those of the ñff-dutyò police and soldiers, or those of land guards. The price on the black market of shotguns ranged between $\$ 500$ and $\$ 1,000$ in 2007 , and that of locally manufactured pistols hovered around $\$ 300$ in 2010 . $^{487}$ Some land guards also use expensive and difficult to access AK-47s and grenades. ${ }^{488}$ The cost of a violent confrontation with the land guards and private-hire state security officers is too high for the subaltern classes to absorb.

The extreme poverty and high unemployment besieging subaltern classes contributed to their recruitment as ñetainers, $\mathrm{o}^{489}$ or land guards. At present, no official figure exists for the numbers of land guards, though interviews with land developers and members of the traditional aristocracy suggest it may be as high as the tens of thousands. For instance, most paramount chiefs have ñyouth associations, ò many of which act as land guards under the guise of customary asafo groups. In another example, one land developer estimated that one land guard group in the Greater Accra Region, the ñUnited Nations, òhas r̃etainedò approximately 6,000 land guards. ${ }^{490}$ Land-guard groups may receive from a few hundred dollars per day to thousands of dollars per month, as well as plots of land, illegal drugs, weapons and vehicles, to provide their services. Land guards also receive protection from legal prosecution, as the contracting party will provide

\footnotetext{
${ }^{487}$ Former regional police commander and current senior official of the Ghana Police Service, personal communication, May 2007.

${ }^{488}$ Youth organizer, personal communication, Accra, June 2006.

${ }^{489}$ Some members of the traditional aristocracy refer to their land guards as ñetainers.ò Alternatively, they may be referred to as customary ñasafo groups, ò though the guards may not be stool subjects and, therefore, would not be considered part of a customary asafo company associated with the stool.

${ }^{490}$ The name United Nations originated from the multi-ethnic nature of this ñumbrellaò group of land guards.
} 
lawyers and links to public officials who can manipulate the security and judicial institutions.

The subculture that has developed amongst land guards reflects the increasingly violent nature of the struggle over land. Guards undergo training in handling weapons, and groups form a loose structural hierarchy. Regular group meetings are not uncommon. Guards also display a distinct style of dress and ritual and adopt individual and group names based on violent action films. By the mid-2000s teenagers began to be recruited. The increasing organizational level of land guards has not altered the client-patron relationship. Groups do not appear to have sought to be independent of a patron or to challenge the power of patrons.

To conclude, subalterns periodically launched violent attacks on chiefs, local government officials or private buyers of land, but most kept their objections quiet. Few subaltern groups now attempt to confront the ruling class over the rapid commodification and skewed land market. Subaltern classes are unable to assert their interests in a context in which the dominant faction of the ruling class controls the courts, land administration, and coercive bodies, in addition to manipulating the traditional aristocracy. Ultimately, the ruling class remains stronger than the peasant class, particularly when private force determines control over land.

\section{Conclusion: Central Questions of the Dissertation}

The processes of economic and political liberalization contributed to the violent nature of the land market that appeared in Ghana in the 1990s. We turn our attention 
again to the central questions of the dissertation: how did the ruling-class use land in its strategy to access and retain power? Who benefitted from the changing relations in land, and who was excluded?

The PNDC faction of the ruling class had largely succeeded in containing violence over land during the 1980s, because it sought to build a base among the subaltern classes. The elections of 1992 suggest that it did succeed in building strong support amongst the rural dwellers and the urban poor, with the exception of the Ashanti region. ${ }^{491}$ Having secured this base, it could then use land as a means of accumulation, rather than as a tool to gain rural support.

The transition to democracy signaled a change in strategy across the ruling-class factions to gain and retain power. Elections required the factions to gather votes from loyal followers and swing voters. Patronage emerged as the predominant method to obtain votes and reproduce voter loyalty. The electoral democracy meant that the patronage system had to be maintained both by the dominant faction in power and by the faction out of power. Elections also proved increasingly costly. In short, the ruling-class factions sought sources to accumulate wealth that would enable them to finance elections and patron-client relations, both while in and out of power.

The ruling class also controlled the process of democratization. The PNDC had agreed to democratize primarily following external, donor pressure and not internal demands from subaltern classes. This enabled it to create new institutions, and promulgate the 1992 Constitution, in a way that would further its interests Both factions

${ }^{491}$ Nugent, Big Men, Small Boys. 
of the ruling class reached some consensus on the institutions that emerged during the democratization process, most notably the security and intelligence arm of the state.

Private coercion became important to the process of ruling-class accumulation. The dominant faction of the ruling class could not directly use the coercive institutions to appropriate land and land-based resources, nor could it mobilize these institutions to suppress the rival faction. The newly reformed security apparatus was weak institutions and contributed to foster the private use of the statế coercive institutions as well as of private militias. The changes to security associated with democratization had unintended negative effects, such as increasing crime, violence and corruption. In the land sector, the ruling class hired off-duty personnel of the state security institutions and private land guards, which often overlapped with customary asafo companies and private security companies. The ruling class contracted and equipped these private coercive forces to assist it in appropriating land.

Local party patrons and the traditional aristocracy became increasingly involved in local disputes, mobilizing political linkages with security and other institutions to bolster their positions. The deepening of patronage-based politics fed tensions and violence over land and land-based natural resources, including diamonds, gold, salt, and timber.

The shift away from supporting subaltern interests in land inevitably led to peasants losing control over land and its resources. Changes to the institutions that regulated the traditional aristocracy, which put the chiefs in charge of customary justice, reduced the ability of stool and clan subjects to contest land allocations and to demand 
accountability for land and resources revenues. The dismantling of the CDR structure that had provided local arbitration on land and housing issues left the subaltern classes with no means to resolve disputes. By using violence and patronage the ruling class undermined subaltern attempts to confront the state and private developers. Contrary to the expected outcomes, democracy led to the increasing exclusion of subaltern classes from control over customary lands.

The sections above have argued that the transition to democracy changed both the means to access power and accumulate wealth, and the ways in which the coercive arm of the state could be used by ruling-class factions. The transition to democracy contributed in multiple ways to the changes in land relations and the increasingly violent nature of disputes in the land market. The struggle between the factions of the ruling class to consolidate political and economic power appeared more prominently following democratization. The factions no longer sought to build a substantial alliance with the subaltern classes based on issues such as land. Instead, the factions dominated the lower classes, subsuming them in patron-client relationships and subduing them with the power of state and private coercion. At the same time, the ruling-class factions subordinated the subaltern classes through the patron-client relationship. While conflicts over land had been part of Ghanaôs political history, the overlay of electoral politics onto pre-existing and contemporary disputes contributed to increasingly violent land relations. 


\section{Chapter 6. Answering the Questions on Ghana's Land}

\section{Violence}

"What greater grief than the loss of one's native land."

- Euripides

This dissertation posed the following fundamental questions: What caused land violence to escalate in Ghana? How are land relations changing? Who benefits by and who is excluded from this process of change? Why does the state fail to stop the growth of violence over land that poses a political threat? Land is a central locus of class relations in the politics of Ghana; therefore, the dissertation uses a class analysis to examine three primary components of political strategy across different historical periods. It examines the role of land in ruling-class strategies to gain power and accumulate resources, and it explores various forms of coercion used to implement those strategies. The analysis provides answers to the core questions and attempts to formulate explanations more satisfactory than those provided by other approaches. To conclude, this chapter begins by briefly comparing historical periods in each area of analysis. The next section, in order to provide greater clarity, addresses the secondary questions of the research. This chapter concludes the dissertation by highlighting the contributions of the research to broader debates, to applications of the research to policy, and to suggestions for future inquiries on land disputes and conflicts. 


\section{Section 1. Review of Case and Comparative Analysis}

\section{Means of gaining power}

Ghanaôs case suggests that the accepted means to gain and retain power influence the nature of land relations. These factors also shape the character and degree of violence that occurs in disputes over land. In the two periods of authoritarian rule studied, the coup dêtat was not only the primary means of acquiring, but also of losing power and land. What varied between the two periods was the ruling class factionô strategy to retain dominance.

Briefly, the National Redemption Council/Supreme Military Council regime used a patronage strategy that relied on ensuring the loyalty of senior military and government officials. The ruling class expected the chiefs to deliver support from the subaltern classes. The ruling class faction in power appropriated communally owned land and attempted to control reallocation of stool lands. To do this, it aligned with the favored chiefs and encouraged allocation that would benefit the ruling class faction in power. This political strategy triggered an increase in the rate of land commodification. However, the reallocation of land excluded subaltern classes from both the use of and the revenues that accrued to customary authorities. The subaltern classes objected to the allocations, which defied custom and harmed their livelihoods. Conflict and violence erupted in those areas where land had been appropriated. Subaltern classes sporadically attacked and sabotaged farms owned by officials or their close allies.

The PNDC also came to power through a coup and perceived an opposing coup as the greatest threat to its power. However, it adopted an alternative strategy to retain 
power. The PNDC built up the coercive apparatus of the state and used it to suppress threats of another coup. State coercive bodies prevented acquisition and movement of weapons and also prevented the rival ruling-class faction from acquiring the money to organize a coup. This approach did not rely on high-level patronage to incorporate government and military officials; instead, it sought the support of the subaltern classes, including rural smallholder farmers, peasants and urban poor. This strategy extended also to land relations. The PNDC responded to the dissatisfaction of subaltern classes that had built up over previous land deals. It funneled land conflicts through security institutions, offering customary subjects quick ñjustice. ò In effect, it sanctioned class violence against customary authorities that were suspected of malfeasance in the management of communal lands. The PNDC strategy to bolster its power, including its strength in land relations, through support of the subaltern class, triggered a countermovement in the commodification of land. Land relations tipped to favor subaltern classes, or, at least, benefited the ruling class less than in the past. Increased security measures also ensured the suppression of large-scale conflicts between subaltern classes, and the ruling class and traditional aristocracy.

The dissertation then compares the periods of authoritarian rule with the countryôs transition to democracy. Elections became the most effective means to garner power, and votes became the greatest threat to the ruling classô control over the state. Violence over land increased during and after the transition to democratic elections. The strategies of the ruling class under an electoral system created this change in the nature of the violence. As the introductory chapters point out, the transition to electoral politics did not 
represent a rupture with prior forms of political organization and social relations. Rather, the ruling class factions intensified their use of the patron-client strategy for elections. Once again, the dominant ruling class faction that held power ensured its members greater access to the most valuable land. Powerful allies and political clients of the faction in power obtained land for construction of residential estates and commercial development on former farmlands. However, the ruling class factions also subsumed subaltern classes in the patron-client networks by promising economic favors for votes. Consequently, farmers, poor tenants and customary subjects rarely resisted being evicted from lands acquired by wealthy political patrons and their clients. Ruling-class patronage, in its efforts to gain electoral dominance, rendered subaltern classes relatively weak. These changes to political strategy also created differences in the character of disputes. Violent conflicts erupted between members of the ruling class competing for valuable land and land-based resources. Subaltern classes became ñetainersò of the ruling class factions, fighting to defend ruling class land acquisitions.

Violence over land appeared most prominently during these three periods when the ruling class factions deployed patronage as the strategy to acquire and retain power. The ruling class used similar strategies to gain power in both systems; the form of the regime, whether authoritarian or democratic, did not necessarily constitute the most important factor in land violence. In all cases, the instrumental value the ruling class placed on land to achieve political objectives drove the level and nature of violence over land. In addition, the comparison of the three periods suggests that the greatest violence is not necessarily found in confrontations between the ñcapitalistò and proletariat classes. 
Rather, the worst violence tended to occur during disputes between the factions of the ruling class.

\section{Means of accumulating}

Access to power and retention of control over the state are closely linked with accumulation. Ruling-class accumulation serves two purposes: personal consumption and patronage redistribution that enables it to dominate other classes and rival factions of the ruling class. The ruling class in Africa struggles for political power in part to accumulate wealth through the state, and it then uses that wealth to retain power and build more wealth, ultimately towards consolidating a factionôs power. Within this context, land holds both financial and political value. This is particularly true when land becomes a central means for ruling-class accumulation. Land was not always the primary means through which the ruling class accumulated wealth in Ghana. The degree to which land figured in ruling-class accumulation strategies varied. Land retained some value for ruling class accumulation during the NRC/SMC period, but its value declined during the subsequent PNDC era. The ruling class sought to accumulate through land most prominently under electoral democracy. The ruling-class factions required substantial revenues to maintain patronage and organize electoral campaigns, for periods both in and out of power. Land provided a means to acquire money needed to access political power, so is not surprising that the ruling class became more willing to engage in violence to acquire that land. 
To review, the ruling class strategy for accumulation during the NRC/SMC period relied much more on direct access to the state, through import licenses, supply contracts and the like, than on land. Officials and others tied to the ruling faction, such as military officers, acquired land primarily in rice-growing areas of the northern part of the country and pursued public housing contracts in a few peri-urban areas. Violence erupted in a limited number of geographical areas, primarily where the ruling class had manipulated the customary institutions that controlled land allocations and had, by doing so, been able to appropriate land for themselves. A few disputes arose over access to prime agriculture lands near water and other natural resources. Relatively weak subaltern resistance to the ruling class faction in power and its allied customary authorities often characterized these disputes.

The PNDC, however, generally discouraged ruling-class accumulation of wealth. This strategy enabled the government to prevent rivals from acquiring wealth that could be used to take power. More specifically, the PNDC gained ñpopularò support among the subaltern classes through preventing accumulation through land acquisition. . The public discourse went against traditional authorities, often based on charges of mismanagement of land and land revenues, and discouraged the transfer of land from communal to private holdings. The early period of PNDC rule actually returned customary lands to interim committees that represented subaltern interests. The initial phases of stabilization and structural adjustment reinforced the PNDC $\hat{Q}$ restrictive position on land. Decreased access to credit reduced private demand and constrained the commercial development of land, slowing commodification of land. 
In contrast, the ruling class sought land for private investment and commercial development during the transition to democracy. The ruling class shaped the institutions that would regulate land relations during democratization, largely to further their interests. Land offered a means for the ruling class to accumulate wealth both in and out of power, providing its members with financial security and social status. This was critical in a context in which power alternates between factions. Added to that, costly patronage-based political-party campaigns required greater accumulation of wealth. Ruling-class factions invested in electoral campaigns because state power would enable future opportunities for accumulation. Speculation and development of land and landbased resources provided a reliable strategy to accumulate personal wealth and to meet the costs of building patron-client networks and elections. Land and land-based resources became so important to building wealth that the ruling-class factions used violence to acquire and defend them.

Ultimately, the ruling class sought to accumulate wealth to preserve its political power and to consolidate factional power. The fractious ruling class applied political strategies that excluded rivals from amassing resources, preventing these rivals from mounting strong electoral campaigns and cultivating competing patron-client networks. The struggle to control resources became increasingly antagonistic. Contention spread between factions, including political parties, as each sought new ways to exclude challengers from financial and patronage power. Local election of patrons to positions of power provided factions with the potential use of state access to consolidate their power. The superimposition of multi-party electoral politics onto factional struggles for power 
and control of resources further raised the stakes for local clients. Control over land became highly politicized.

\section{$\underline{\text { Use of coercion }}$}

The capitalist notion of property rights assumes that the ruling class shapes property rights to its benefit. The ruling class is then expected to use the security apparatus of the state to defend its property rights and interests. However, the Ghana case suggests far more complexity in land relations and in the creation of a property-rights system. Land serves political and accumulative interests simultaneously, and these interests can be contradictory. Accumulating land can provide revenue for redistribution to build and reinforce the patron-client network. At the same time, appropriating land can deny livelihoods for the lower classes and can create resistance to the ruling class. The introduction of the multi-party electoral process further complicated the enforcement of a land-rights regime in Ghana.

In this case, a factional ruling class sought a means to enforce control over land and land-based resources from which it could benefit. It did not want to enforce all land rights $i ̈$ only the rights of their own factions. The transition to democracy, in which new institutions were being established and old institutions dismantled, provided the opportunity for the ruling class to pursue its own interests. Democratic norms entailed the dismantlement of the coercive apparatus built under authoritarian regimes; this in turn, left a gap in security and weakened the institutions that should defend property rights. As this occurred, the factional ruling class began to use p̃privatized coercionòto defend its 
own interests. In some cases, the ruling class factions used public coercive bodies for personal disputes and in other cases engaged private ñland guardsò to fight for acquired land. In general, the state lost its monopoly over force, enabling private disputants to fight over the reallocation of land. Disputes became more violent than in previous periods. A comparative overview of the case illustrates this point.

The NRC/SMC used state coercion directly to enforce allocation of land and impose it on subaltern classes. The allied traditional authorities also used customary means to intimidate the stool or skin subjects, such as threats of poisoning or spiritual harm,. This suppressed challenges to the ruling factionôs claims on property, but it did not eliminate them. Conflicts and tensions over land were rampant by the time the regime was overthrown in 1979.

The PNDC adopted a new political strategy strengthening the coercive bodies of the state. New and strengthened ñsecurityò institutions became directly involved in enforcing land rights. But rather than support the rights of the ruling class, many in the coercive apparatus sought to defend the rights of the subaltern classes. The PNDC also used the coercive institutions to prevent ruling class rivals from acquiring land. The faction in power deployed coercive force to defend lower-class interests in land, because that course of action aligned with its strategy to mobilize subaltern political support.

The public discourse on equality in land and the strength of the stateôs coercive bodies both began to decline with the introduction of electoral politics $i$ first at the local and then at the national level. The dominant classes placed particular emphasis on the reform of coercive bodies during the institutional reform that accompanied 
democratization. The ruling class used the period to ñdemocratize democracy,ò by which it meant to create civilian control over security services and lower the stateô coercive capacity. In so doing, the ruling class substantially weakened and in some cases eliminated the coercive institutions that had mediated land disputes. The ruling class decreased domestic security budgets, reconfigured the district-level government security apparatus, lowered executive control over arms imports, and weakened border controls, which led to an influx of weapons. The de-prioritization of public order and coercion led to the ñprivatizationò of security. The ruling class privately engaged state security agencies and contracted private security companies and militias.

Th lack of a state monopoly on coercion, and the weakened security institutions, created the space for violence over land. The ruling class employed violent means to retain land acquisitions without state interference. The ruling class built private militias, obtained and protected land acquisitions, and defended militias from prosecution through patron-client links in state institutions. At the same time, the stateôs weakened coercive apparatus could not control the clashes between the armed groups. The ruling class held a disproportionate advantage in violent disputes over the traditional aristocracy and customary subjects. The ruling class tended to wage protracted, bloody disputes. At times, political patrons employed young men as guards on the land they were losing. State coercive institutions were ineffective in the rare instances when they tried to intervene. Ruling-class factions continued to invest in violence because land disputes had become entangled in their political struggle for dominance. 


\section{Section 2. Causes of Land Violence in Ghana: Answers from Case}

\section{$\underline{\text { Analysis }}$}

Changes in the nature of conflict and violence over land are evident across the historical periods compared. At times, conflict occurred between the subaltern classes and a dominant ruling class faction, and at other times such conflict was confined primarily to factions within the ruling class. The level and nature of the violence over land varied according to the classes that were fighting. The ruling class mobilized the state to subdue the occasional destructive acts of violence and sabotage by subaltern classes. But the ruling class inhibited the state from quelling lengthy confrontations between the factionsô own private militias and guards. Across cases, the drive for land was predominantly fueled by political objectives.

Beginning with the NRC/SMC, the political strategy of patronage focused on supporting those in government and building up local patrons. The faction in power rewarded its own officials and local patrons with land that helped them to accumulate wealth. This created disputes over land between the ruling class factions, alongside their local patrons, and subaltern classes were excluded from expropriated land and land revenues. It is not surprising that subaltern classes acted according to their means, engaging in relatively disorganized sabotage, property destruction and personal attacks. The state responded with coercive enforcement of land holdings, which benefited the ruling faction. Tensions over land were rife in those areas where the ruling class had appropriated land. 
Alternatively, the PNDC sought to retain power not just through coercion, but through an alliance with subaltern classes. The ruling class strengthened the state coercive apparatus to retain its power, largely through coup prevention. At the same time, the PNDCôs political program to gain the loyalty of the urban and rural poor played on existing tensions over land and landed property. The ruling faction used the state coercive apparatus to bolster this political agenda. It strengthened subaltern classes control over land and land-based resources, weakened the role of the customary authorities over those resources, and prevented the rival faction from accumulating resources, including land, that might threaten the PNDCôs power. This use of the stateôs coercive power coincided with early stabilization and structural adjustment policies that constrained credit. The multi-pronged strategy for retaining power slowed the commodification process in land. It also restricted violent conflict over land. However, the decline in violence over land rights stopped with the advent of democracy.

Democratization led to unexpected outcomes. Land conflict became most destructive and widespread following the introduction of electoral politics, irrespective of which political party was in power. Electoral politics exposed the underlying intra-rulingclass struggle for state power and resources. Factions reformed institutions during democratization to suit their own complex interests. Dismantled and diminished security institutions could scarcely enforce laws or contain violence. The ruling class expanded opportunities to acquire land, but failed to create mechanisms for accountability. Political parties used land intensively in their patronage strategies while, at the same time, land served the economic ends of this developing ñupper classò, providing a secure form of 
investment and social status both in and out of power. Ultimately, the messy mix of acquiring land for both political ends and wealth building amid intra-ruling-class struggles created an upsurge in land-related violence.

Democracy failed to bring about the increased political opportunities expected by the subaltern classes $\ddot{i}$ opportunities that would allow them to pursue their interests in land resources peacefully. Rather, local land conflicts became increasingly politicized. The ruling class, needing both land and votes, subsumed the subaltern classes under patron-client networks as they fought among themselves for an increasing share of what had been communal, customary lands.

Land relations: Gains and losses in the change from communal rights to political allocation and ñmarket-likeòaccess

How and to what are land relations changing?

The landholding pattern introduced in Chapter 2 can now be revisited to examine changes in land relations. The case suggests that the primary type of landholding is gradually moving away from communal usufruct rights. Leases based on customary access are less likely to be granted than they once were. Research also suggests a decline in customary access to farmland by peasants. The number of landless peasants is growing, despite constitutional rights of customary access. Smallholder farmers are also losing access to land that will appreciate in value. Subsistence and smallholder farmers will likely lose their ability to transfer land to heirs. 
On the other hand, those without customary access but with political or economic means are more likely to obtain leases. Leases are also more likely to be shorter: usually less than half the formerly typical 99 years. The number of individuals with transferable, non-customary leases is rising. This allows for increased speculation and for renewed leases to those without customary access.

Social relations in land are shifting. Those gaining access to land are characterized by financial access and by their connections to state institutions and political power. Power derived from the customary right to allocation is declining in importance. The critical component of power in land relations is increasingly access to financial resources to acquire and secure land, alongside necessary access to the state institutions to register land and retain land. This requires revisiting the schema of land relations presented in Chapter 2. The new configuration is represented below (Figure 6.1).

Figure 6.1. Opportunity to Access Land.

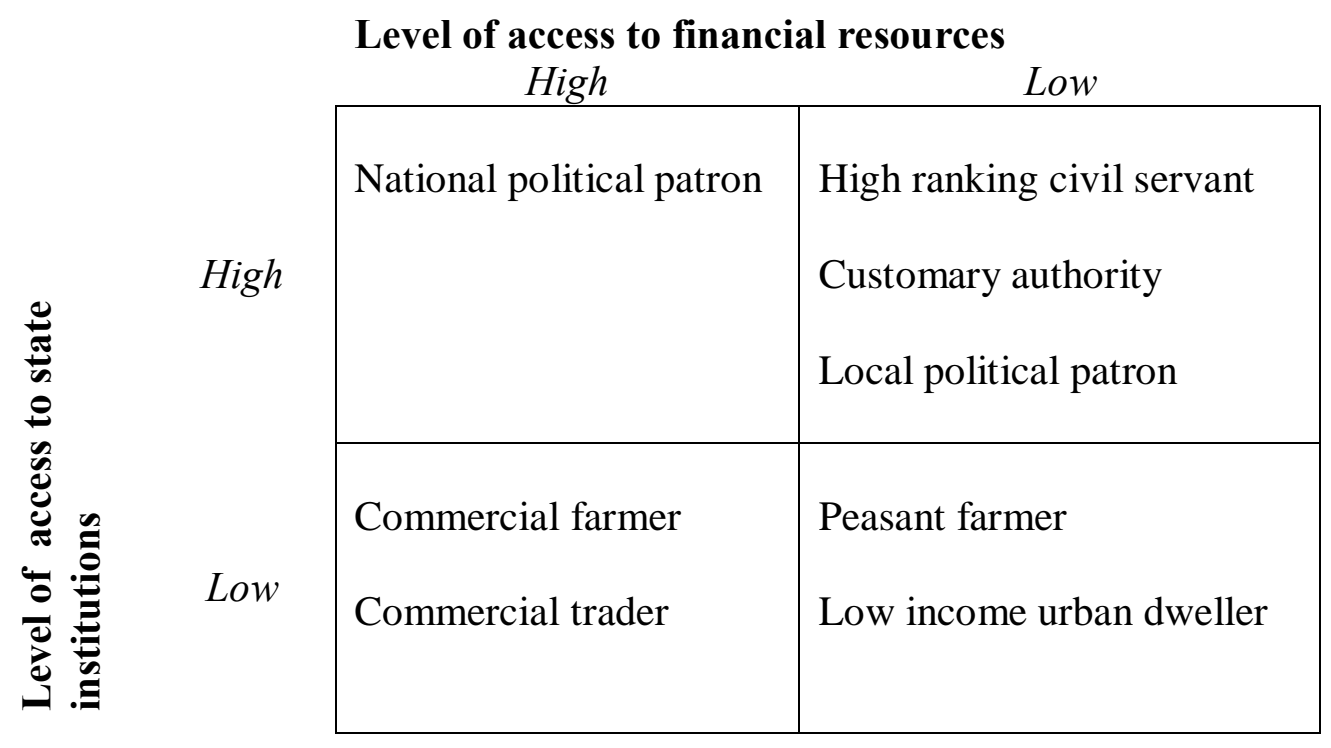


Alternatively, the above may also be represented in a ladder of land access, as depicted below (Figure 6.2). Location on the ladder relates to the ability to control and secure land acquisition. Expressed in this way, those with access to small areas of land for subsistence, or for a mix of subsistence and smallholder farms, have often been pushed to the lower rungs of the ladder. At the other end, those with greater control over acquisition through political and financial resources have been able to climb toward increased access, larger acquisitions and less-encumbered leases. The key observation is that movement on the ladder is increasingly limited. Control over land can be maintained more effectively with access to state land-management institutions $\ddot{i}$ institutions that have the governmental ability to enforce documentation as well as the financial ability to ñenforceò landholding independently of the coercive arm of the state.

Figure 6.2. Ladder of Access to Land.

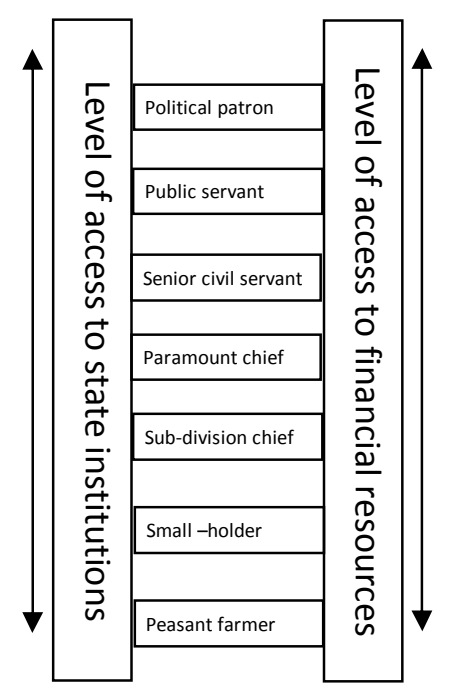


This changing pattern in control over land reflects corresponding changes in class relations. Legally, land is held in trust for the subjects of customary stools by the traditional aristocracy. Land effectively ñbelongsò to the people. Most land in Ghana is customary land. Customarily, communal ties provided a right to access land through a non-monetary exchange with the customary authority. This relationship gave the customary leaders authority, even legitimacy, with the subaltern classes. However, as the above ladder suggests, customary ties and traditions are no longer the primary determinant for land acquisition. Accumulation of land by the ruling class in a noncustomary exchange can deprive customary subjects of their current and future livelihood. The ruling class weakens the subaltern classes in order to acquire that land and reduces their social position further by depriving them of the livelihood they earn from the land.

The traditional aristocracy appears to benefit from the transition to a land market. It gains economically from land rates and also retains social power by virtue of its role in allocating land. However, the chiefô position is also altered as class relations change around land acquisition and disputes. The traditional aristocracy loses authority in a number of ways as land markets become ñfree.ò First, a chief loses control over land use in his customary jurisdiction under a non-customary lease. Second, he loses authority over his subjects when he no longer has land to redistribute. Third, the politicization of land allocation and the participation of the chief in politics undermine the legitimacy of the chief. Finally, the fact that the chief is not accountable to his subjects for land revenues also erodes his legitimacy. In sum, land cannot be the basis for the relationship 
between the customary leaders and their subjects as that land is transferred out of communal hands.

The traditional aristocracy has little power without control over land allocation. At present, the politically generated resources that chiefs redistribute to their subjects provide a weak substitute for land in the relationship between the two. In some areas in Ghana, chiefs have already lost authority through land transfers; in some cases, political parties no longer include them as local patrons in the patron-client network. In the medium to long term, commodification of land may eliminate the role for chiefs as intermediaries between the ruling class and the chiefsôsubjects.

The case points to changing land and class relations as the allocation of land moves away from a customary system. However, the case exhibits no evidence that a free market in land is ñnaturallyò evolving. Land relations may appear to be moving toward a market system, but it would be premature to state that this constitutes a free market in land. First, land leases, in most cases, are not freehold; customary land continues to be held, if only nominally, in trust by chiefs for their subjects. Land can revert to the traditional aristocracy if the type of use stipulated in the lease changes. The constitutional, legal status of land belonging to customary subjects leaves open the possibility for future political interference and for the return of lands to customary subjects. Courtsôrulings in these cases have not been consistent. Second, access to land still requires interaction with the customary authorities. This often involves a personal introduction or reference from someone with a communal tie to the land or to the customary authority. The customary authority as intermediary does not fit neatly with the 
conception of an open and free market. Third, financial payments on long-term leases to customary leaders are not made through typical market models, but instead are often tendered through unscheduled cash payments, termed ñdrinkò payments. Fourth, and perhaps most important, land allocation is not based on a disinterested ideal of profit. Rather, it is often determined based on political objectives: The ruling class faction in power seeks to create and sustain loyal patrons and clients. Access to land tends to alternate with changes in the ruling political party, with those in the patron-client network seeking to obtain and secure land while their faction is in power. Finally, land ownership has not become concentrated in the hands of capitalists seeking to mobilize it for production. These characteristics of the emerging trends in allocation and control over land prevent the assertion that it is an ñevolving free market."

Who is benefiting by, and who is being excluded from, this process?

In short, the subaltern classes are being excluded in the reconfiguration of land relations. This discussion highlights land re-allocationôs effect upon economic position. Gains or losses may be related to $\ddot{i}$ but do not equate to $і ̈$ changes in relative class power. The arrangement of landholding can transform the current and future livelihoods of those who lose or gain access.

Mostly clearly, the lower classes are being excluded from economic livelihood as land possession is rearranged. Loss of access to communal, customary land deprives these classes of potential livelihoods in farming and in developing land. They lose land, including land that they had previously farmed, and move to urban areas. But they cannot 
be fully absorbed into the labor market. Compensation, if paid at all, cannot sustain livelihoods in a context of high urban costs. Dislocation and economic marginalization have been particularly pronounced in peri-urban areas and mining zones, including areas where oil exploration has recently begun. Though the lower classes have rights to land in the letter of the constitution, they have been pushed to the bottom of the land ladder.

The traditional aristocracy fares better than the lower classes, but this does not make it a ñwinnerò in long-term changes in land ownership. Land revenue is often inadequate to improve the chiefôs livelihood. Chiefs may also use revenue for conspicuous consumption or grand social events for clients. Beyond an initial payment, traditional councils lack the capacity to collect annual ground rates, an additional payment in lease agreements that is meant to provide long-term income. The state itself fails to pay these ground rents on land leased from customary authorities. Interventions by donors who seek to strengthen the capacity of traditional councils are ad hoc and unlikely to be sustained. In addition to the limited monetary benefits they reap, chiefs also lose harvest tributes from customary landholders and must do without the labor for their own farms that formed part of the obligation of customary land recipients. The traditional aristocracy cannot be considered an obvious ñwinnerò if the allocation of land continues along its present path.

The real ñwinnersò of the changes in land relations, then, are those in the ruling class with access to adequate political or bureaucratic power to acquire land and secure its possession, whether through title or coercion. Those who obtain land are the leading members of political parties, small numbers of semi-skilled entrepreneurs, educated 
professionals, and senior civil servants. They compose the petite bourgeoisie, often neither peasant nor capitalist. For them, properly titled and uncontested landholding can provide a secure investment that endures regardless of the political party in power. They gain both the status and the income that flow from rental property. They also speculate in land, reselling acreage bought below the market value or sub-dividing leased land into smaller plots. More revenue can be added when the original leased farmland is re-zoned for residential estates, a transition facilitated by the stateôs expansion of the electricity grid. Through such improvements to their economic well-being, those in the ruling class have benefitted from their control over land.

$\underline{\text { A violent process of change: the nature of conflict over land }}$

What causes violence in the process of change in land relations? Why does the state ignore this violence when it poses a political threat?

The case suggests that the nature of the ruling class itself is the underlying cause of the rising violence over land. The factional nature of the ruling class, and the struggle between factions for political dominance, fueled conflict in all the periods compared. Analysis shows that land conflict in Ghana did not begin with structural adjustment, but has occurred in different historical periods to varying degrees. The degree of conflict varied in relation to the political strategy of the ruling class faction in power. The policies that emanated from strategies to retain power and accumulate wealth had direct bearing on the rate of land commodification. Likewise, the stateô response to land-ownership conflict $\ddot{i}$ and, more particularly, to how the ruling class deployed coercion $\ddot{i}$ also 
changed with the dominant ruling class factionôs strategy to retain power. Under multiparty electoral democracy, the factions seeking to gain lasting control over the state have unleashed strategies causing the most destructive violence of the periods reviewed.

Several factors were important to understanding the variation in violence across the periods compared. Primarily, the centrality of the role of land in the intra-ruling class struggle influenced the levels and nature of violence. Violence declined when the ruling class faction in power sought to use land to gain subaltern support, deploying its coercive apparatus to support subaltern land interests and deter opponentsôinterests. On the other hand, violence escalated when the ruling class factions emphasized land acquisition in their strategy to accumulate wealth and to build patron-client networks. This was particularly pronounced when it was combined with an electoral competition for political dominance. The instrumental role of land in this strategy increased its value. Land became worth fighting for when it gained both political and then accumulation value, moving beyond even the narrow conception of the market. Land became critical to intertwined political and monetary objectives.

Class composition constituted a decisive difference in the nature of the conflict in this case. In the periods prior to democracy, land conflict was characterized by a struggle between the ruling class and subatlern classes trying to resist expropriation of communal land. In such struggles, the ruling class faction in power would deploy its coercive apparatus to support its favored disputant and repress its rivals in land conflicts. The apparatus could easily subdue the lower classes and contain any violence. However, the class composition in disputes differed during the democratic period. Disputes tended to 
be intra-ruling class, and less often between the ruling class and lower classes. The ruling class manipulated customary institutions to acquire lands, contributing to contested land leases and titles, with different members of the ruling class claiming the same land. Disputants engaged armed guards and militias to fight for land. In most cases, subaltern classes allowed the expropriation of their customary lands. The ruling class factions had greater capacity to purchase destructive weapons and to contract militias to engage in violence. Each faction has attempted at times to strengthen its position by violent means, increasing control over land and land-based resources, and relying equally on patronage to bolster its position over subaltern classes. State security institutions, weakened through the democratic reform process, failed to prevent intra-ruling-class violence.

More importantly than weak coercive capacity, the dominant faction in the ruling class had vested interests in land conflicts. Many in the dominant faction that controlled state institutions were themselves engaged in land conflicts. The relationship between political strategy and land appropriation discouraged them from strengthening state institutions to contain violent land conflicts. In the democratic period, the ruling class could further its political and economic interests in land through private violence more effectively than through state coercion.

The political strategies of patronage and accumulation through land acquisition generated contradictions. Leaders participated in the reallocation of customary lands to members of the ruling political class through customary and local party leaders. At the same time, parties sought subaltern class votes through the same patronage system, also mediated by customary and local party leaders. Political survival under a multi-party 
electoral system could be undermined if one faction openly used state power to expropriate land from the subaltern class. Private violence had less impact than public coercion on the ruling classôs electoral objectives.

Briefly, the factional nature of the ruling class, with its contradictory strategies for political survival, has shaped the current approach to land appropriation. It has contributed to the primitive accumulation of land, a situation in which private violence is a tool for establishing and maintaining political power outside the institutions of the state. Intra-ruling-class conflict is played out in the rearrangement of landholding. Private violence replaces and inhibits the creation of state-monopolized violence as the ruling class attempts to gain dominance through renegotiating land relations and influencing corresponding class relations.

\section{$\underline{\text { Section 3. An Alternative Argument for Land Violence }}$}

The analysis above provides a complex explanation for an increase in violence emerging alongside a convoluted process of change in land relations in Ghana. An additional question follows this argument. Is this explanation for land-related violence more robust than the theories introduced in earlier chapters? A brief overview of the answers this study offers suggests that it may be a more comprehensive and dynamic approach.

Rational-choice theory emphasizes that the promise of profit motivates individuals to gain control over resources. People employ rational means to obtain beneficial economic ends. Markets comprise individuals operating on this profit-seeking rationale. Violence 
can occur through clashes between profit-seeking individuals, particularly where the risk of engaging in violence is justified by the potential profit from the ñbootyò to be won. Such violence is also more likely where law and order are not state-ensured. Democracy can improve the efficiency of this market by providing equal opportunities for individuals to exchange information and seek their interests within a context of rule and law. Its adherents expect democracy to enhance their property rights. Therefore, land violence should decline under a democracy, particularly with the establishment of laws and regulations that secure land title.

In the case studied here, rational-choice theory fails to provide an explanation for land-related violence, and, more to the point, for increased violence in the wake of market liberalization and democratization. The case anticipated that democracy would create a capitalist class that would advocate for more systematic and secure property rights. It also anticipated that violence would decline in areas where land registration, or titling of ownership and leases, is the most advanced. The opposite occurred in the Ghana case.

Rational choice has two major weaknesses in explaining this case. First, rational choice assumes the existence of capitalists who operate only on the profit incentive; it ignores the nonprofit motives of the actors. The observations from this case suggest that non-market-based incentives are critical to land-relations outcomes. An emerging and internally conflicted ruling class did not make choices based on the profit incentive alone. Rather, ruling-class motives to gain dominance over other factions in its own class and over subaltern classes fueled different strategies. At times, the ruling class sought financial resources, but it often did so to achieve political objectives, such as financing 
for electoral campaigns. Second, rational choice does not adequately consider the foundations and origins of institutions. Democratic elections have not ensured strong, benign state institutions in Ghana. The ruling class reformed institutions to ensure that it controlled the reallocation of resources. Given the inability of rational-choice theory to explain fundamental outcomes in land relations following democratization, the alternative explanation provided here is stronger. It analyzes underlying ruling-class power incentives that shape the dismantling, changing or creation of institutions used to reallocate resources. It is therefore better able to explain the unexpected outcome of violence that followed a transition to democracy.

Agency explanations attempt a more nuanced analysis than means-end rationality. The agency literature argues that there is a process of social change under way in tenure relations in Africa that cannot be explained by general economic theories. Agency studies highlight the contingent conjunctures of case-specific factors and emphasize the agency of individuals amid changing social relations over land. The causes of violence tend to be specific to each case, but they are influenced generally by power relations within the local context.

Despite the attention to power relations, agency also falls short of providing an adequate explanation for the Ghana case. The theory often fails to identify patterns; it always depends on the constantly varying contexts. At the same time, it has discounted the importance of class relations and state power in local land relations. The present study, however, reveals patterns and broad power relations in land across historical periods and regimes in Ghana. The ruling class has used land as a tool in strategies to 
obtain power through patronage and class alliances, to encourage primitive accumulation within the patron-client network, and to generate financial resources for political activity. Actors at the local level leverage access to state power and make alliances with the ruling class to gain local power and to consolidate dominance over other local actors in relation to local resources. The ruling class has implemented its strategy to dominate alternative factions and subaltern classes, even at the local level, either through or with the tangential support of state institutions. The case also reveals a pattern in the use of coercion to defend land allocation by the state and the ruling class. As exemplified here, the approach presented does appear to provide a stronger explanation than agency theories for the recent rise in land violence in Ghana.

Structuralists explain land relations and land-related violence through class analysis, as shown in this study. Structural analysis focuses on the role of changing class interests and relations in the violence of socio-economic transitions. Structuralists place local disputes over land in the context of a changing global political economy. They identify groups with clear interests in land disputes, and they seek to address the process by which the groups pursue these interests. They tend to highlight the conflicts between capitalists and workers and peasants. This analysis is situated in the formation and changing nature of state and political institutions. Structuralists use this approach to identify patterns in land-related violence linked to changes in the global political economy.

While this is a fundamentally more rigorous analysis, structural studies also have weaknesses. Many class studies of land violence diminish the role of the local ruling 
class, reducing them to mere agents of global capital. The studies also tend to use landconflict cases to argue the relevance of the working class and the revolutionary potential of land. In addition, many existing class analyses attempt to use neat categories of peasant, proletariat and capitalist. They then reduce land conflict to a struggle between global capitalists and subaltern (either peasant or semi-proletariat) classes. The case of Ghana refutes such tendencies to simplify the class groups, their interests and the means through which they achieve their ends. As such, this study sought to use a structural approach while avoiding its usual weaknesses.

First, this study did not seek to answer the question of the potential for land to be the locus of revolution. Looking for the revolutionary potential of land disputes begins with assumptions that cloud the analysis. In the case of Ghana, the analysis required an understanding of the process of class formation and a suspension of the assumption that capitalists and the proletariat already exist. In any case, class distinctions are not always clear. For the most part, Ghanaôs ruling class is embryonic and trying to consolidate. The state institutions provide a vehicle to pursue this primary objective. These lower-class individuals may be making the transition to a property-owning class, but they cannot yet be defined as capitalists. In this way, land appears to have more potential for consolidating ruling-class formation than for initiating revolution among subaltern classes.

In a second and related point, this study examined class conflict as taking place both between and within the forming classes. Studies that limit cases to land violence between the capitalist class and the lower classes fail to capture most of the land violence in Africa 
in what is now referred to as a ñocal land grab.òThe study was able to address more of the pernicious cases of land violence by not selecting a case with a clear ñglobal capitalò interest in conflict with an opposing domestic subaltern class. This approach included the fact that the worst violence in Ghana has occurred as intra-ruling class conflict over land. Subaltern classes lack the means to effectively confront the ruling class with violence. This prevents continuous, destructive violence in land disputes between the subaltern classes and the ruling class.

Third, this study attempted to give more attention to historical context than do some structural case studies. It analyzed changes in land relations over a number of political periods. The historical comparison suggests that the violence over land ñdid not begin yesterday,ò but has taken different forms throughout Ghanaôs history. The historical background creates the basis for eliminating structural adjustment, and this type of penetration of global capital into Africa, as the primary cause of land violence.

Fourth, the present analysis recognizes the political agency exercised by the ruling class and those with access to state power. It inherently questions the assumption of a singular and overwhelming dominance by global capital. During the periods compared in this case, there was little evidence of a ñglobal land grabò in Ghana. ${ }^{492}$ Multinational companies did not drive the reallocation of land in the timeframe studied. Rather, it found that the ruling class has its own interests in power and in means of dominance. The local ruling class mediates the effects of the limited domestic capitalist interest and the few cases of external (global) capitalist interest. It shapes the outcomes of neo-liberal

${ }^{492}$ More recent evidence suggests that may be changing and that international interests in land in Ghana are increasing. 
institutional reform encouraged by bilateral and multilateral donor agencies. The domestic ruling class largely determines who will benefit in Ghana. The evidence shows that very few ñglobal capitalistsò accumulated wealth from these early stages of reallocation of land resources in Ghana, but many in Ghanâ̂ ruling class were enriched by the reallocation.

Briefly, the modified structural analysis identified the underlying cause of land violence in Ghana by avoiding the failures and weaknesses of other approaches. Its main finding is that the factional nature of the emergent ruling class is the primary causal factor explaining the violent form of land transactions in Ghana.

\section{Section 4. A Limited Explanation and the Need for Further Study}

The explanation to land-related violence provided in this study appears from the information above to be more robust than other approaches, at least for explaining the case of Ghana. However, the broader applications of the approach, as well as the limits of the study, also require mention.

The argument provided in this study does not explain every case of violence over land in Africa, or even in Ghana. The study is restricted to a specific and narrow definition of violence. To revisit this definition, the study highlighted cases of land conflict that involved acquisition of land through physical force. It deliberately omitted cases of ñeconomicòviolence in which people were deprived of their means of livelihood. A more comprehensive definition of violence would incorporate a broader study of contested land and could identify more causal factors. 
This study could be expanded to include case studies that compare areas situated within peri-urban areas, such as the greater Accra region, to rural areas. Ghana is rapidly urbanizing, and farmland is being converted into sprawling cities, as is the case in many developing countries. An in-depth study of specific areas in Ghana could offer a closer look at rising peri-urban land demand and increased conflict over land in the transition to private real-estate development and non-farming commercial land use. That transition could be compared with the rise in demand for large plots of land for commercial farming. Cases of violence over rural lands are not as common as they are for peri-urban lands. A comparison between the two within the Ghanaian context would further explain the motives to engage in conflict over land and would pinpoint the cases in which actors are willing to invest in violent means to acquire land.

More generally, the case studied here is within just one country in Africa. The level of explanation is quite specific. The question of the cause of land violence could be applied to a larger case sample and the explanation could be generalized. The landholding patterns identified as specific to Ghana could be generalized to incorporate other holding patterns in Africa that originated from different customary and colonial histories. For example, a variety of colonial structures and independence movements created diverse forms of land ownership. Ghana retained the institution of chieftaincy, and customary authorities continued to hold communal land in trust, whereas Ivory Coast created a system of direct and individual ownership during the colonial period. Studies across more diverse landholding systems would test the class theory proposed here. 
In addition, cross-regional comparison could introduce cases outside of Africa with quite different landholding and land-conflict patterns. Latin American cases could provide a contrast for comparison, since landholding in Latin America was characterized by the location of estates alongside smallholder farms. In Ghana and much of Africa, peasant subsistence farms and even smaller, smallholder farms were dominant. Large estates were found in only a few settler colonies in Africa. In addition, broad subaltern movements over land issues are unusual in most of Africa, with South Africa and, to a limited extent, Zimbabwe serving as the exceptions. A preliminary look at the Ghanaian case suggests that subaltern classes have not organized and consolidated attempts to confront the state over land issues. On the other hand, South America has more cases of subaltern movements organized and mobilized around the issue of land. A comparative study of this sort could highlight more differences in land relations and land-related violence.

A broader comparative comparison should not be limited to contemporary cases. The Ghanaian case, largely identified here as an intra-elite conflict, could also be compared to historical cases. For instance, the theory presented here could be examined within a comparative study between Ghana and the enclosure movement in England. A comparison of primitive accumulation amid intra-elite conflicts between England and Ghanaôs emerging ruling class could enable further refinement of theories on the role of land and primitive accumulation in the formation of the ruling class. A comparative study of contemporary Ghana and some areas of the American West could investigate the types of violence deployed by the ruling class when it is acquiring communal lands. Analysis of 
land reallocation and associated violence should incorporate comparisons across historical periods.

The consequences, both economic and social, of violence over land require greater attention. The focus has been on the causes of violence, rather than the broader effects. This case suggests a number of areas where the consequences for changes in landholding require further study. First, the evidence showed that violence over land contributes to demand for small arms. However, it also appears that in areas where there is armed violence over land, there is a corresponding increase in armed crimes. These correlations require further study. Second, this analysis did not address the issue of what happens to subaltern classes, particularly farmers, after they lose their land. During my research, current and former government officials, traditional authorities and land developers familiar with displacement of customary landholders stated that the individuals who are displaced ñjust go.òNo one said where they go, or what they do when they get there. An obvious assumption is that they go to the cities. In a context of high unemployment and low industrial capacity, land reallocation is likely contributing to the explosion of slums. ${ }^{493}$ In addition, recent census reports in Accraôs slums revealed that men who formerly worked to guard land have moved into slum areas, which has coincided with increased violent crimes in those areas. ${ }^{494}$

\footnotetext{
${ }^{493}$ The current estimates suggest more than 50 percent of Ghanaians live in urban areas and that 70 percent of urban dwellers live in slum conditions. This would mean more than eight million Ghanaians live in slums, with that number increasing daily. For more on the global trend toward slums, see: Mike Davis, Planet of Slums (London: Verso, 2007).

${ }^{494}$ Peoples Dialogue, personal communications, Accra, 2010.
} 
Finally, the study raises questions about the management of land historically used for farming. Peri-urban farmland is being converted to housing and commercial properties despite the lack of zoning and regulation The loss of peri-urban farms is likely to increase transportation costs on food, and, hence, the cost of food for city dwellers. This in turn threatens to deepen urban poverty. Studies on land conflict, therefore, suggest the need to go beyond the causes of violence to understand their effects on broader social and economic conditions.

In conclusion, the study presented here would benefit from broader regional and historical comparisons. Violence has often accompanied primitive accumulation in land, and this study provides another case that can enable us to understand the process of violent primitive accumulation and the early forms it takes as countries forge land markets. The case also suggests the need to understand both short- and long-term effects of changes in land relations and reallocation of land resources. Further studies would enable differentiation between types of land violence and would address other pertinent questions: Who is fighting over land, and what are the larger social and economic outcomes of this fighting? Why do some land conflicts ñspill overò and contribute to civil wars, while others remain local and contained? Why is primitive accumulation in land often violent, and does that violence vary across historical periods? In sum, the present explanation derived from a single case in Africa could be refined through testing across other cases in Africa and through cross-regional comparison. 


\section{Section 5. Recommendations for Development-oriented Policy and}

\section{Planning}

Development planners rank effective land management as fundamental to good governance and economic growth, as well as to improved livelihoods in agriculture-based economies. ${ }^{495}$ Researchers have begun to identify the far-reaching negative consequences of chaotic land schemes. Land systems are now being incorporated into debates regarding food security, preventive health, productive water use and sustainable natural-resource management. As such, this study offers lessons for future development planning across a wide range of issues.

Based on the study, specific policy recommendations may be made for Ghana. Ghana must reconsider the position of its traditional aristocracy and customary authorities in governance of district assemblies and land. The current policies assume that chiefs are benevolent and apolitical leaders in communities, and that customary systems accurately represent the customary subjects. However, this belies the close relationship between the traditional aristocracy, the political process, and the appropriation of natural resources by the ruling class. The case shows collusion between chiefs and political patrons in reallocating land to suit the interests of the ruling class and deprive customary subjects of its use. It shows that the relationship between chiefs and subjects is fractious. It also confirms that the constitutional provision for state non-intervention in chieftaincies has not reduced political interference. Similarly, rules prohibiting chiefs from political-party activity have not ensured neutrality. And the state has not carried out the requirement for

${ }^{495}$ Deininger and Binswanger, ñThe Evolution of the World Bankôs Land Policy.ò 
representation of the marginalized despite its quota on district assemblies and through unit committees in the communities. The customary authorities, whether land priest, queen mother or chief, does not automatically provide ñsocial capitalò that can be mobilized for development. A significant lesson from the study is that mechanisms to defend the rights of subjects, and not just to preserve chieftaincies, must be implemented. An additional policy message specific to Ghana concerns the payment of royalties. Royalties are the annual ground rents due to the traditional authorities on all leases; the Office of the Administrator of Stool Lands is responsible for collecting these royalties. The research in this case revealed the stateôs refusal to pay royalties accruing to stools in cases of chieftaincy disputes. The state argues that it cannot identify the chief to whom to make payments. It is not surprising that a large number of chieftaincies in areas with rapidly rising land values are under dispute; greater Accra is an example. The case also suggests that revenues garnered from land leases generally do not benefit customary subjects. Customary authorities may allocate high-value lands for lease, but their customary subjects often lack adequate infrastructure and social services, such as primary schools. The recommendation that follows from this context is to pay royalties into trusts or foundations targeted at specific social programs and projects in those customary areas. Techniques exist and are used in other sectors, such as water rights, to incorporate local communities into decision-making on intervention, the type of infrastructure to build, and the location of the project(s). These methods could be used to identify the best use of land royalties with customary subjects, and this process could be undertaken regardless of chieftaincy succession disputes. The process could then be managed through strengthened 
unit committees of local assemblies. It is likely that the ruling class will still attempt to control those resources, but this new institutional arrangement would encourage greater participation of local communities in the use of land revenues and in local government structures as a means of ensuring accountability and reducing conflict.

The case also holds lessons for policy beyond Ghana. Certainly, the case suggests improvements to program design in good governance. Donors continue to advocate for democracy for greater accountability of governments. Donors, as well as scholars, evaluate the presence of democracy through the observation of periodic ñfree and fairò elections and through changes to the political party in power. By those measures, Ghana is a relatively institutionalized democracy. But Ghanaôs experience illustrates the limitations of that approach. It also raises examples for future interventions in democratization.

First, democracy cannot be evaluated based on a series of elections. As Ghana shows, elections do not generate equal participation of all elements of society in governance; nor do they ensure accountability of elected leaders. Democracy in Ghana has been a process under continual negotiation, with the most powerful factions dominating the subaltern classes. Ghanaians must develop more effective measures for success in democracy. To achieve any measurable progress in accountability, they must put into place processes that ensure broad representation, enforcement of positive rights, and equal access to justice.

Second, democratic elections do not ensure rights, such as the right to justice, to citizens. Notably, subaltern classes in Ghana perceive a loss of land rights and a 
continuing lack of access to justice since the introduction of democracy. Arbitration programs sometimes place the customary authorities as arbiters, rendering the service ineffective for most land cases. Access to arbitration can also be too costly for the poor. A decentralized system of courts that does not require lawyers or demand high fees could help to ensure access to justice for the poor. The government must take steps to institutionalize and ensure citizensômost important rights.

Third, the institutional reform process is a critical stage in the transition to democracy. Within this process, the destruction of old institutions is as important as the creation of new ones. Most notably from the Ghana case, dismantling security services does not prevent the ruling class from controlling the coercive apparatus of the state. On the contrary, the withdrawal of security services leaves gaps in policing and in the prevention of corruption and violence, and the rise of crime and violence curtails the freedoms promised during the introduction of democracy. Evidence from the Ghana case suggests that if security declines, the public will lose confidence in the democratic dispensation. Security services, including the agencies responsible for combating fraud and corruption, should not be stripped down with the advent of democracy. States must retain their monopoly on coercive force as an essential part of ensuring peace and stability.

An additional lesson derived from the case is that effective land policy is not necessarily guaranteed by the creation of ñproperty rightsò institutions such as title registries. This lesson translates into specific recommendations. First, the government must design institutions to ensure that subaltern classes have access to the same services 
as the ruling class. Schemes exist in other sectors, such as microfinance and education, to ensure the provision of services to those who are illiterate, undocumented, and too poor to pay. Institutions and procedures from the PNDC provide models for reforming landrelated institutions to ensure this access. Second, the government must augment title institutions by establishing or strengthening institutions that enforce the titles. As the case of Ghana shows, a title has little meaning in a context where ñconquestò of land is defended by ñetainers, ò no matter who holds a title that is registered with state institutions. Titles will not provide security for credit and investment unless they actually secure ownership or leases. Land-administration projects will deliver none of the positive outcomes promised by donors and policymakers until there is an effective system to ensure equal access to titling, as well as enforcement of titles.

The above recommendations for policymakers and decision-makers are useful for discussion. However, the recommendations must be qualified. This study concluded that formal institutions such as constitutions, land policies, title regimes, and land management authorities, fail not because of poor policy or low capacity. They fail instead because the ruling class implements policies that ensure land transfers from customary users to the ruling class. This is likely to continue until the majority of land has been reallocated to the ruling class. In short, policies are not the primary problem in land governance; the problem is that that they are implemented according to the political and financial interests of the ruling class. Policy discussions have value only when they consider political imperatives and class relations in a real context. Until fruitful 
discussions take place, outcomes will continue to bear scant resemblance to the positive results anticipated by theorists, donors, and policymakers.

\section{Conclusion: Consequences of the Violence over Land}

This study does not seek to argue that democracy is the primary cause of violence over land. Democracy is an idea, or set of ideas, which cannot act, and therefore, cannot cause violence. However, democracy is transformed from ideas into institutions, rules and practices by people in a society ñorganizedò into classes. It is these classes that determine the shape of the democratic institutions, which includes the important property rights institution. The factors of causation relate to those classes. In Ghana, the ruling class is divided and its primary objective is to consolidate power and keep power. Therefore, it shaped the democratic institutions and property rights institutions to achieve those ends. Multi-party elections occurred in the context of intra-ruling class competition as factions sought to consolidate their power, not to consolidate institutions that were representative or created equality. Ultimately, the argument is that the real causal factor for violence over land was the intra-ruling class conflict.

The conclusion to this study requires a return to the definition of violence. This study defined violence narrowly to enable a focused inquiry into the causes of harmful action and physical confrontation over land. That research contributes to the larger body

of literature on land conflict in developing economies. It provides a detailed case study on the political origins of a violent land market, which is characterized by pernicious conflict that does not spread into larger civil war. The cause of this type of land violence is the 
ruling-class use of coercive force, alongside bureaucratic authority, to control land allocation as a means to gain dominance and state power. However, it is important to return to the ñcomprehensiveò definition of violence to understand the long-term consequences of this intra-class struggle on customary land holders.

A broader definition of violence incorporates psychological damage, economic deprivation, and denial of rights. Those alienated from the land, as opposed to those who suffer injury or death from the immediate combat over land, are the clear victims of violence as broadly defined. In the letter of the law, Ghana@̂ poor ï the peasant and smallholder farmers, fisher folk, and artisanal miners $і ̈$ retain their rights to the land. The customary right to land is enshrined in the constitution and no Ghanaian may be landless. Yet, such land ownership is meaningless without the actual right to use the land. The đandedôpoor will become unable to rely on customary land as part of a livelihood strategy. Furthermore, the same people will be unlikely to reclaim their right to land in future decades when current leases expire. As such, they will continue to be excluded and land will be reallocated according to the principles of the ớreeôreal estate market. The ruling class is forming alongside this land market, but the dispossessed are those who suffer the greatest violence. 


\section{Bibliography}

Addo-Fening, R. Akyem Abuakwa 1700-1943: From Ofori Panin to Sir Ofori Atta.

Trondheim: Norwegian University of Science and Technology, Faculty of Arts, 2000.

Addo-Fening, R. "Chieftancy and Issues of Good Governance, Accountability and Development: A Case Study of Akyem Abuakwa under Okyenhene Ofori Atta I, 19121943." In Chieftancy in Ghana: Culture, Governance and Development, edited by Irene K. Odotei and Albert K. Awedoba. Accra: Sub-Saharan Publishers, 2006.

Agboton-Johnson, C., E. Adedeji and L. Mazal. ñSmall Arms Control in Ghana, Nigeria and Senegal.ò West Africa Series, No. 2 (English). London: International Alert, 2004.

Agyeman-Duah, Baffour. "Ghana, 1982-1986: The Politics of the P.N.D.C." The Journal of Modern African Studies 25, no. 4 (1987): 613-642.

Agyeman-Duah, Baffuor. Curbing Corruption and Improving Economic Governance: The Case of Ghana. Accra: Center for Democracy and Development, n.d..

Aidoo, Thomas Maxwell. "Political Involvement in a Democratizing Neo-patrimonial Polity: The Case of Ghana - 1992-2000." Research Review: Institute of African Studies 22, no. 2 (2006): 13-36. 
Amanor, Kojo S. ñGlobal Restructuring and Land Rights in Ghana: Forest Food Chains, Timber and Rural Livelihoods.ò Research Report, No. 108. Uppsala, Sweden: Nordiska Afrikaininstitutet, 1999.

Amanor, Kojo S. ñLand, Labour and Family in Southern Ghana: A Critique of Land Policy under Neo-libearlism.ò Research Report, No. 116. Uppsala: Nordiska Afrikainstitutet, 2001.

Amanor, Kojo S. "Night Harvesters, Forest Hoods and Saboteurs: Struggles over Land Expropriations in Ghana." In Reclaiming the Land: The Resurgence of Rural Movements in Africa, Asia and Latin America, edited by Sam Moyo and Paris Yeros. London and New York: Zed Books, 2005.

Amnesty International. ñColombia: Hacienda Bellacruz: Land, violence and paramilitary power. Amnesty International.ò AMR 23/006/1997, February 1, 1997. Accessed http://www.unhcr.org/refworld/docid/45b899242.html.

Andre', Catherine and Jean-Phillipe Platteau. "Land Relations under Unbearable Stress: Rwanda Caught in the Malthusian Trap." Journal of Economic Behavior and Organization 34 (1998): 1-47. 
Aning, E. Kwesi. ñThe Anatomy of Ghanaôs Secret Arms Industry.ò Armed and Aimless: Armed Groups, Guns and Human Security in the ECOWAS Region. Geneva: UNODC, 2005.

Aning, Kwesi E. "Chieftancy, Land Conflicts and Conflict Resolution Mechanisms in Ghana." Accra: Kofi Annan International Peacekeeping Training Centre, 2005.

Aning, Kwesi E. "An Overview of the Ghana Police Service." Journal of Security Sector Management 4, no. 2 (2006): 1-37.

Appiahene-Gyamfi, J. ñAn Analysis of the Broad Crime Trends and Patterns in Ghana.ò Journal of Criminal Justice 30 (2002): 229-243.

Arthur, Peter. "Promoting a Local Entrepreneurial Class in Ghana: The Issues and Problems." Canadian Journal of African Studies 39, no. 3 (2005): 427-459.

Asabre, P. K. "The Determinants of Land Values in an African city: The Case of Accra, Ghana." Land Economics 57, no. 3 (1981): 385-397.

Asante, S. K. B. Property Law and Social Goals in Ghana, 1844-1966 (Accra: Ghana Universities Press, 1975). 
Assibey-Mensah, George O. "Budgeting in Ghana: Innovations, Problems and Prospects." Public Budgeting and Finance 17, no. 2 (1997): 89-113.

Atwood, D. A. ñLand Registration in Africa: The Impact on Agricultural Production.ò World Development 18, no. 5 (1990): 659-671.

Ault, D. E. and G. L. Rutman, ñThe Development of Individual Rights to Property in Tribal Africa,ò Journal of Law and Economics 22, no. 1 (April 1979): 163-182.

Ault, D. E. and G. L. Rutman. ñLand Scarcity, Property Rights and Resource Allocation in Agriculture: Eastern and Southern Africa,ò South African Journal of Economics 61, no. 1 (March 1993): 20-28.

Austin, D. and R. Luckham. Politicians and Soldiers in Ghana: 1966-1972. London: Cass, 1975.

Austin, D.. Ghana Observed: Essays on the Politics of a West African Republic. Manchester: Manchester University Press, 1976.

Ayee, Joseph R. A. "A Decade of Accountability under Ghana's Provisional National Defence Council (P.N.D.C.) Government." Research Review 10, no. 1 and 2 (1994): 6176. 
Ayee, Joseph R. A. "Conflict Resolution and Grievance Redressing Mechanism at the District Level in Ghana: Myth or Reality." In Democracy and Conflict Resolution in Ghana, edited by Mike Oquaye. Accra: Frederich Ebert Foundation/Gold-Type Publication, 1995.

Ayee, Joseph R. A. "Some Thoughts on the Institutional Representation of Chiefs in the District Assemblies and the Sub-district Structures." In Chieftancy in Ghana: Culture, Governance and Development, edited by Irene K. Odotei and Albert K. Awedoba. Accra: Sub-Saharan Publishers, 2006.

Azam, Jean-Paul. ñThe Redistributive State and Conflicts in Africa.òJournal of Peace Research 38, no. 4 (2001): 429-444.

Baer, Denise and Bryan Shari. "Money in Politics: A Study of Party Financing Practices in 22 Countries." Washington, D.C.: National Democratic Institute for International Affairs, 2005.

Bah, Alhaji. ñMicro-disarmament in West Africa: The ECOWAS Moratorium on Small Arms and Light Weapons.ò African Security Relations 13, no. 3 (2004): 33-46.

Barber, William J.. ñLand Reform and Economic Change Among African Farmers in Kenya.òEconomic Development and Cultural Change 19, no. 1 (1970): 6-24. 
Barrows, Richard L. and Michael Roth. ñLand tenure and Investment in African Agriculture: Theory and Evidence.ò The Journal of Modern African Studies 28, no. 2 (1990): 265-297.

Bassett, T.J. and D. E. Crummey, eds. Land in African Agrarian Systems. Madison, WI: University of Wisconsin Press, 1993.

Bates, Robert. Markets and States in Tropical Africa: The Political Basis of Agricultural Policies. Berkeley, CA: California University Press, 1994.

Bawumia, M. ñUnderstanding the Rural-Urban Voting Patterns in the 1992 Ghanaian Presidential Election: A Closer Look at the Distributional Impact of Ghanâ̂ Structural Adjustment Programme.ò The Journal of Modern African Studies 36, no. 1 (1998): 47-70.

Bay, Edna G.. "Introduction." In States of Violence: Politics, Youth and Memory in Contemporary Africa, edited by Edna G. Bay \& Donald L. Donham. Charlottesville and London: University of Virginia Press, 2006.

Bay, Edna G. and Donald L. Donham, eds. States of Violence: Politics, Youth and Memory in Contemporary Africa. Charlottesville and London: University of Virginia Press, 2006. 
Bayart, Jean-Francois. The State in Africa: Politics of the Belly. London: Longmans, 1993.

Bayart, Jean-Francois. Africa Works: Disorder as Political Instrument. Oxford: James Currey, 1999.

Bayart, Jean-Francois, Stephen Ellis and Beatrice Hibou. The Criminalization of the State in Africa. Oxford and Indiana: James Currey and Indiana University Press, 1999.

Beissinger, Mark R. and Crawford Young, eds. Beyond state crisis? Postcolonial Africa and Post-Soviet Eurasia in Comparative Perspective. Washington, D.C.: Woodrow Wilson Center Press, 2002.

Benjaminsen, Tor A. \& Christian Lund, eds. Securing Land Rights in Africa. London: Frank Cass, 2003.

Berdal, Mats \& David Malone, eds. Greed and Grievance: Economic Agendas in Civil Wars. London and Boulder, CO: IDRC/Lynne Rienner, 2000.

Berman, Bruce. ñóA Palimpsest of Contradictionsô Ethnicity, Class and Politics in Africa.ò International Journal of African Historical Studies, 37 (1) (2004): 13-31. 
Bernstein, Henry. "Rural Land and Land Conflicts in Sub-Saharan Africa." In Reclaiming the Land: The Resurgence of Rural Movements in Africa, Asia and Latin America, edited by Sam Moyo \& Paris Yeros. London and New York: Zed Books, 2005.

Berry, Sara. ñHegemony on a Shoestring: Indirect Rule and Access to Agricultural Land.ò Africa 62, no. 3 (1992): 327-355.

Berry, Sara. Chiefs Know Their Boundaries: Essays on Property, Power and the Past in Asante, 1896-1996. Portsmouth, NH: Heineman/Oxford: James Curry/Capetown: David Phillip, 2001.

Berry, Sara. ñDebating the Land Question in Africa.ò Comparative Studies in Society and History 44, no. 4 (2002): 638-668.

Bestemen, Catherine. Unraveling Somalia: Race, Violence and the Legacy of Slavery. Philadelphia: University of Pennsylvania Press, 1999.

Boafo-Arthur, Kwame. "Ghana's Politics of International Economic Relations under the PNDC, 1982-1992." African Study Monograph 20, no. 2 (1999): 73-98.

Boafo-Arthur, Kwame. "Chieftancy and Politics in Ghana since 1982," West Africa Review 3, no. 1, (2001): 1-16. 
Boahen, Adu. ñGhana: Conflict Reoriented.òIn Governance as Conflict Management: Politics and Violence in West Africa, edited by I. William Zartman. Washington, D.C.: Brookings Institution Press, 1984.

Bobo, Benjamin. "Population Density, Housing Demand and Land Values: The Case of Accra, Ghana." Journal of African Studies 4, no. 2 (1977): 140-160.

Bobrow-Strain, Aaron. Intimate Enemies: Landowners, Power and Violence in Chiapas. Durham, N.C.: Duke University Press, 2007.

Bratton, Michael. ñFormal Versus Informal Institutions in Africa.ò Journal of Democracy 18, no. 3 (2007): 96-110.

Bratton, Michael and Nicolas van de Walla. ñPopular Protest and Political Reform in Africa.ò Comparative Politics 24, no. 4 (July 1992): 419-442.

Bratton, Michael and Nicolas van de Walle. Democratic Experiments in Africa: Regime Transitions in Comparative Perspective. Cambridge: Cambridge University Press, 1997. 
Bruce, John W. ñLand Tenure Issues in Project Design and Strategies for Agricultural Development in sub-Saharan AfricaòLand Tenure Center Paper No. 128. Madison, Wisc.: University of Wisconsin, 1986.

Bruce, J.W. and S. E. Migot-Adholla. Searching for Land Tenure Security in Africa. Washington, D. C.: World Bank, (1994).

Bryceson, D. ñDisappearing Peasantries? Rural Labour Redundancy in the Neo-liberal Era and Beyond.òIn Disappearing Peasantries? Rural Labour in Africa, Asia and Latin America, edited by D. F. Bryceson, C. Kay \& J. Mooij, 299ї 326. London: Intermediate Technology Publications, 2000.

Bryceson, D. F. and L. Bank. ñEnd of an Era: African Development Policy Parallax.ò Journal of Contemporary African Studies 19, no. 1 (2001): 5-23.

Callaghy, Thomas M. ñState, Choice and Context: Comparative Reflections on Reform and Intractability.òIn The New Realism in Sub-Saharan Africa, edited by E. Apter \& C. Rosberg. Charlottesville, VA: University Press of Virginia, 2003.

Chabal, P. and J. P. Daloz. Africa Works: Disorder as Political Instrument. Bloomington, ID: James Currey,1999. 
Chazan, Naomi. An Anatomy of Ghanaian Politics: Managing Political Recession, 19691982. Boulder, Colo.: Westview Press, 1983.

Chazan, Naomi and Deborah Pellow. Ghana: Coping with Uncertainty. Boulder, CO: Westview Press, 1986.

Collier, P. ñDoing Well Out of War: An Economic Perspective.òIn Greed and Grievance: Economic Agendas in Civil Wars, edited Mats Berdal and David Malone. London and Boulder, CO: IDRC/Lynne Rienner, 2000.

Collins, P. and E. Hansen, E. "The Army, the State and the 'Rawlings Revolution' in Ghana." African Affairs 79, no. 314 (1980): 3-24.

Cramer, Chris. ñHomo Economicus Goes to War: Methodological Individualism, Rational Choice, and the Political Economy of War.ò World Development 15 (2002): 397-412.

Cramer, Christopher. Violence in Developing Countries: War, Memory, and Progress. Bloomington, IN: Indiana University Press, 2007. 
Crook, Richard C. and James Manor. Ghana. In Democracy and Decentralisation in South Asia and West Africa, edited by Richard C. Crook and James Manor. Cambridge, New York and Melbourne: Cambridge University Press, 1998.

Cudjoe, Samuel M. "The Effects of Head of Family (Accountability) Law 1985 (PNDCL 114) on Ga Mashi Head of Family." LL. B. Paper, University of Ghana, 1989.

Daloz, Jean-Pascal. ñóBig Menôin Sub-Saharan Africa: How Elites Accumulate Positions and Resources.ò Comparative Sociology 2, no. 1 (2003): 271-285.

Dalton, George. ñTraditional Production in Primitive African Economies.ò Quarterly Journal of Economics 76, no. 3 (1962): 360-378.

Daniels, W. C. Ekow. ñSome Principles of the Law of Trust in West Africa,ò Journal of African Law 6, no. 3 (September 1962): 164-178.

Daudelin, Jean. Land and Violence in Post-conflict Situations. Ottawa: The North-South Institute and the World Bank, 2003.

Davis, Mike. Planet of Slums. London: Verso, 2007.

Degenaar, J J. ñThe Concept of Violence.ò Politikon 7, no. 1 (1980): 14-27. 
Deininger, K. The Evolution of the World Bank's Land Policy. Washington, DC: World Bank, 1998.

Deininger, K. \& Binswanger, H. ñThe Evolution of the World Bankôs Land Policy: Principles, Experience, and Future Challenge.ò The World Bank Research Observer 14, no. 2 (1999): 247-76.

Deininger, Klaus. Land Policies for Growth and Poverty Reduction. Washington, D.C.: The Bank for Reconstruction and Development/The World Bank and Oxford University Press, 2003.

Deininger, K. \& Castagnini, R.. "Incidence and Impact of Land Conflict in Uganda." Policy Research Working Paper. Washington, D.C.: World Bank, 2004.

Diamond, Larry. "Class Formation in the Swollen African State." The Journal of Modern African Studies 25, no. 4 (1987): 567-596.

Downs, R.E. and S. P. Reyna, eds. Land and Society in Contemporary Africa. Hanover: University of New Hampshire, London: University Press of New England, 1988. Fairbanks, Jr., Charles H. ñWeak States and Private Armies.òIn Beyond state crisis? Postcolonial Africa and Post-Soviet Eurasia in Comparative Perspective, edited by Mark 
R. Beissinger and Crawford Young. Washington, D.C.: Woodrow Wilson Center Press, 2002.

Farhan, Edward and Zaidi Miguel. Do Politicians Reward Their Supporters? Public Spending and Incumbency Advantage in Ghana. Berkeley, CA: University of California, 2003.

Fatton, R. Haiti's Predatory Republic: The Unending Transition to Democracy. Boulder, Co.: Lynne Rienner Publishers, Inc, 2002.

Feder, G., T. Onchan, Y. Chalamwong and C. Hongladarom. Land Policies and Farm Productivity in Thailand. Baltimore: Johns Hopkins University Press, 1988.

Firmin-Sellers, K. ñThe Politics of Property Rights.ò The American Political Science Review 89, no. 4 (1995): 867-881.

Firmin-Sellers, K. and P. Sellers. ñExpected Failures and Unexpected Successes of Land Titling in Africa.ò World Development 27, no. 7 (1999): 1115-1128.

Fisk, E. K. and R. T. Shand. ñThe Early Stages of Development in a Primitive Economy: The Evolution from Subsistence to Trade and Specialization.òIn Subsistence Agriculture 
and Economic Development, edited by Clifton R. Wharton, Jr. Chicago. Aldine Publishing Co, 1969.

Freund, Bill. The Making of Contemporary Africa: The Development of African Society Since 1800. Boulder: Lynne Rienner Publishers, 1998.

Ghana Integrity Initiative. ñGhanaôs CPI Score Worsens.ò GII Alert 12 (December, 2006).

"Global Integrity Scorecard: Ghana 2009." Accessed at: report.globaintegrity.org/Ghana/2009.

Gocking, Roger S. "Indirect Rule in the Gold Coast: Competition for Office and the Invention of Tradition." Canadian Journal of African Studies 28, no. 3 (1994): 421-446.

Goheen, Miriam. ñChiefs, Sub-chiefs and Local Control: Negotiations Over Land, Struggles Over Meaning.ò Africa 62, no. 3 (1992): 389-412.

Goody, Jack. "Rice-burning and the Green Revolution in Northern Ghana." The Journal of Development Studies 16, no. 2 (1980): 136-155. 
Government of Ghana. Programme for Reconstruction and Development. Accra: Government of Ghana, 1982.

Grant, Richard. "The Emergence of Gated Communities in a West African Context: Evidence from Greater Accra, Ghana," Urban Geography 26, no. 8 (2005): 661-683.

Gray, Leslie and Michael Kevane. ñDiminished Access, Diverted Exclusion: Women and Land Tenure in Sub-Saharan Africa.ò African Studies Review 42, no. 2 (1999): 15-39.

GREDA. "Ghana Housing Report: A Discussion Paper Submitted to the IFC." Accra: Ghana Real Estate Developers Association, 2009.

Green, J. K. ñEvaluating the Impact of Consolidation of Holdings, Individualization of Tenure, and Registration of Title: Lessons from Kenya.òLand Tenure Center Paper No. 129. Madison: University of Wisconsin-Madison, 1997.

Gurr, Ted R. and Vaughn F. Bishop. "Violent Nations, and Others." Journal of Conflict Resolution 20, no. 1 (1976): 79-109.

Hammond, John L. "Law and Disorder: The Brazilian Landless Farmworkers' Movement." Bulletin of Latin American Research 18, no. 4 (1999): 469-489. 
Hansen, E. Ghana under Rawlings: Early Years. Lagos: Malthuse Press Limited, 1991.

Hayes, J., M. Roth and L. Zepeda. ñTenure Security, Investment and Productivity in Gambian Agriculture: A Generalized Probit Analysis.ò American Journal of Agricultural Economics 79, no. 2 (1997): 369ї 382.

Hill, Polly. Migrant Cocoa Farmers of Southern Ghana: A Study in Rural Capitalism. Cambridge: Cambridge University Press, 1963.

House of Parliament, Republic of Ghana. "The Parliament of Ghana, Third Meeting. Parliamentary Debates." Accra: Ghana Publishing Corporation, 1993.

House of Parliament, Republic of Ghana. "The Parliament of Ghana, Second Meeting. Parliamentary Debates." Accra: Ghana Publishing Corporation, 1994.

Howard, Phillip. "Development-induced Displacement in Haiti." Refuge 16, no. 3 (1997): 4-11.

Hutchful, Eboe. "A Tale of Two Regimes: Imperialism, the Military and Class in Ghana." Review of African Political Economy 6, no. 14 (1979): 36-55. 
Hutchful, Eboe. "Military Policy and Reform in Ghana." Journal of Modern African Studies 35, (1997): 251-278.

Hutchful, Eboe. Ghana's Adjustment Experience: The Paradox of Reform. Oxford: James Currey, 2002.

Hutchful, Eboe. "Pulling Back from the Brink: Ghana's Experience." In Governing Insecurity, edited by G. Cawthra and R. Luckham. London: Zed Books, 2003.

Information Services Department. Ghana: Two years of transformation: 1983-84. Accra: Government of Ghana, n.d..

Jeffries, Richard. "Ghana: The Political Economy of Personal Rule." In Contemporary West African States, edited by Donal Cruise O'Brien, John Dunn and Richard Rathbone. Cambridge, New York, Melbourne: Cambridge University Press, 1989.

Jeffries, Richard. "Urban Popular Attitudes Towards the Economic Recovery Programme and the P.N.D.C. Government in Ghana." African Affairs 91, no. 363 (1992): 207-226.

Johnson, Omotunde E. G. ñEconomic Analysis: The Legal Framework and Land Tenure Systems.ò Journal of Law and Economics 15, no. 1 (1972): 259-276. 
Kairaba, A. ñCountry Case Study: Rwanda.ò Workshop of The World Bank on Land Issues in Africa and the Middle East, in Kampala, Uganda, April-May 2002.

Kandeh, J. D.. Coups from Below: Armed Subalterns and State Power in West Africa. New York and Hampshire: Palgrave Macmillan, 2004.

Kanyinga, Karuti. ñRedistribution from Above: The Politics of Land Rights and Squatting in Coastal Kenya.ò Research Report, No. 115. Uppsala, Sweden: Nordiska Africainstitutet, 2000.

Kasfir, Nelson, ed. State and Class in Africa (London: Frank Cass, 1984).

Kay, Cristobal. "Reflections on Rural Violence in Latin America." Third World Quarterly 22, no. 5 (2001): 741-775.

Kennedy, Paul. "Political Barriers to African Capitalism." Journal of Modern African Studies 32, no. 2 (2005): 383-393.

Kimble, David. A Political History of Ghana: The Rise of Gold Coast Nationalism. Oxford: Oxford University Press, 1963. 
King, David J. ñLand Reform and Participation of the Rural Poor in the Developmental Process of African Countries.òLand Tenure Center, No. 110. Madison: University of Wisconsin-Madison, 1973.

Kinsey, Bill H. "Zimbabwe's Land Reform Program: Underinvestment in Post-conflict Transformation." World Development 32, no. 10 (2004): 1669-1696.

Kirk, M. ñThe Context for Livestock and Crop-Livestock Development in Africa: The Evolving Role of the State in Influencing Property Rights Over Grazing Resources in Sub-Saharan Africa.òIn Property rights, risk, and livestock development in Africa, edited by N. McCarthy, B. Swallow, M. Kirk, \& P. Hazell, 23-54. Paper presented at the international symposium on property rights, risk and livestock development, Feldafing, Germany, September 1998.

Klopp, Jacqueline. "Pilfering the Public: The Problem of Land Grabbing in Contemporary Kenya." Africa Today 47, no. 1 (2000): 7-26.

Kludze, A. K. P. Ewe Law of Property (London: Sweet and Maxwell, 1973).

Kludze, A. K. P. ñAccountability of the Head of Family in Ghana: A Statutory Solution in Search of a Problem,ò Journal of African Law 31, no. 1-2 (March 1987): 107-118. 
Konadu-Agyemang, K. "The Best of Times and the Worst of Times: Structural Adjustment Programs and Uneven Development in Africa: The Case of Ghana." The Professional Geographer 52, no. 3 (2000): 469-483.

Konadu-Agyemang, K.. "Structural Adjustment Policies and Housing Affordability in Accra, Ghana." The Canadian Geographer 45, no. 4 (2001): 528-544.

Konadu-Agyemang, Kwadwo. "A Survey of Housing Conditions and Characteristics in Accra, an African city." Habitat International 25, no. 1 (2001): 15-34.

Konings, Piet. The State and Rural Class Formation in Ghana: A Comparative Analysis. London, Boston, Melbourne, Henley: KPI Limited, 1986.

Kraus, Jon. "Capital, Power and Business Associations in the African Political Economy: A Tale of Two Countries, Ghana and Nigeria." Journal of Modern African Studies 40, no. 3 (2002): 395-436.

Kufuor, K. Oteng. "Private Sector Housing in Ghana: Some of the Legal Aspects of State Control since 1982." Journal of African Law 37, no. 1 (1993): 46-51.

Kwame, S. Osei and F. Antwi. "The Impact of Land Delivery and Finance in the Supply of Residential Accommodation in the Urban Centres of Ghana: The Case Study of Accra, 
Tema and Kumasi." Masters of Science Thesis, No. 229. Department of Real Estate and Construction, Real Estate and Construction Economics, Royal Institute of Technology, Stockholm, Sweden, 2004.

Larbi, Wordsworth Odame. ñUrban Land Policies and the Delivery of Developable Land in Ghana.ò PhD thesis, Department of Land Management and Development, University of Reading, 1994.

Lartey, Ernest and Kwesi Aning. "Parliamentary Oversight of the Security Sectors: Lessons from Ghana." In Parliamentary Oversight of the Security Sector in West Africa: Security Sector Reform as Conflict Prevention? New York: Center on International Cooperation, New York University, 2009.

Le Billon, Phillipe."The Political Ecology of war: Natural Resources and Armed Conflict." Political Geography 20 (2001): 561-584.

Leblang, David. ñProperty Rights, Democracy and Economic Growth.ò Political Research Quarterly 49, no. 1 (1996): 5-26.

Legal Sub-Committee of the Transitional Team, eds. "Transition Report." Accra: Government of Ghana, 2009. 
Linberg, Steffan. ñtô Our Time to áChopô Do Elections in Africa Feed

Neopatrimonialism Rather than Counter-act It?ò Democratization 10, no. 2 (2003): 121140.

Magnusson, Bruce A. ñDemocratization and Domestic Insecurity: Navigating the Transition in Benin.ò Comparative Politics 33, no. 2 (2001): 211-230.

Malik, Arun \& Robert M. Schwab. ñOptimal Investments to Establish Property Rights in Land.òJournal of Urban Economics 29 (1991): 295-309.

Malpezzi, S. \& Mayo, S. "The Demand for Housing in Developing Countries." Economic Development and Cultural Change 35, no. 4 (1997): 687-721.

Mamdani, M. Citizen and Subject: Contemporary Africa and the Legacy of Late Colonialism. Princeton, NJ: Princeton University Press, 1996.

Markovitz, Irving L. Power and Class in Africa. Englewood Cliffs, NJ: Prentice-Hall Inc., 1977.

Markovitz, I. L. Studies in Power and Class in Africa, New York: Oxford University Press, 1987. 
Marshall, Judith. "The State of Ambivalence: Right and Left Options in Ghana." Review of African Political Economy 5 (1976): 49-62.

Martin, M. ñNeither Phoenix nor Icarus: Negotiating Economic Reform in Ghana and Zambia, 1983-1992.òIn Hemmed In: Responses to Africa's Economic Decline, edited by T. Callaghy and J. Ravenhill. New York: Columbia University Press, 2003.

Migot-Adholla, S., P. Hazell, B. Blarel and F. Place. ñIndigenous Land Rights Systems in Sub-Saharan Africa: A Constraint on Productivity?ò World Bank Economic Review 5, no.1 (1991): 155-75.

Mikell, Gwendolyn. "Peasant Politicisation and Economic Recuperation in Ghana: Local and National Dilemmas." The Journal of Modern African Studies 27, no. 3 (1989): 455478.

Miliband, R.. The State in Capitalist Society. New York: Basic Books, 1969.

Moore, David. ñZimbabweôs Triple Crisis: Primitive Accumulation, Nation-state Formation and Democratisation in the Age of Neo-liberal Globalisation.ò African Studies Quarterly 7, no. 2-3 (2001): 33-51. 
Moore, Donald S. ñClear Waters and Muddied Histories: Environmental History and the Politics of Community in Zimbabweô Eastern Highlands.òJournal of Southern African Studies 24 (2), (1998): 377-403.

Moyo, S. ñAfrican Land Questions, the State and Agrarian Transition: Contradictions of Neoliberal Land Reforms.òWorking Paper Series. Dakar, Senegal: CODESRIA, 2004. Accessed at: http://www.codesria.org/IMG/pdf/Sam_Moyo.pdf.

Moyo, Sam and Paris Yeros, eds. Reclaiming the Land: The Resurgence of Rural Movements in Africa, Asia and Latin America. London and New York: Zed Books, 2005.

Ninsin, Kwame A. ñNotes on Landlord-tenant Relations in Ghana since 1982.ò Research Review NS 5, no. 1 (1989): 69-76.

Noronha, R. "A Review of the Literature on Land Tenure Systems in Sub-Saharan Africa.ò Research Unit, Agricultural and Rural Development Department. Washington, D.C.: The World Bank, 1985.

North, Douglass C. Structure and Change in Economic History. New York: W. W. Norton, 1981. 
Nugent, Paul. Big Men, Small Boys and Politics in Ghana. Accra: Asempa Publishers, 1996.

O'Brien, Donal Cruise, John Dunn and Richard Rathbone, eds. Contemporary West African States. Cambridge, New York, Melbourne: Cambridge University Press, 1989.

Odgaard, Rie ñScrambling for Land in Tanzania: Process of Formalisation and Legitimisation for Land Rights.òIn Securing Land Rights in Africa, edited by Tor A. Benjaminsen and Christian Lund, 71-88. London: Frank Cass, 2003.

Odotei, Irene K. and Albert K. Awedoba. Chieftancy in Ghana: Culture, Governance and Development. Accra: Sub-Saharan Publishers, 2006.

Opoku, Darko K. "Political Dilemmas of Indigenous Capitalist Development in Africa: Ghana Under the Provisional National Defence Council." Africa Today 55, no. 2 (2008): $25-51$.

Oquaye, Mike, ed. Democracy and Conflict Resolution in Ghana. Accra: Frederich Ebert Foundation/Gold-Type Publication, 1995.

Oquaye, M. Politics in Ghana, 1982-1992: Rawlings, Revolution and Populist Democracy. New Dehli: Thompson Press Ltd., 2004. 
Parker, John. Making the Town: Ga State and Society in Early Colonial Accra.

Portsmouth, NH: Heinemann, 2003.

Perelman, Michael. The Invention of Capitalism: Classical Political Economy and the

Secret History of Primitive Accumulation. Durham and London: Duke University Press, 2000.

Peters, Pauline. Dividing the Commons: Politics, Policy, and Culture in Botswana. Charlottesville: University of Virginia Press, 1994.

Peters, Pauline E. ñnequality and Social Conflict Over Land in Africa.òJournal of Agrarian Change 4, no. 3 (2004): 269-314.

Pinkney, T. C. and P. K. Kimuyu. ñLand Tenure Reform in East Africa: Good, Bad or Unimportant?ò Journal of African Economies 3, no. 1 (1994): 1-28.

Platteau, J. P. ñLand Reform and Structural Adjustment in Sub-Saharan Africa: Controversies and Guidelines.òFAO Economic and Social Development Papers, No.107. Rome: FAO, 1992.

Platteau, J. D. ñThe Evolutionary Theory of Land Rights as Applied to Sub-Saharan Africa: A Critical Assessment.ò Development and Change 27 (1996): 29-86. 
Platteau, J.P. ñDoes Africa Need Land Reform?ò In Evolving Land Rights, Policy and Tenure in Africa, edited by C. Toulmin and J. Quan, 51-74. London: IIED, 2000.

Prunier, G. The Rwanda Crisis 1959-1994: History of a Genocide. London: Hurst and Co, 1995.

Quarcoopome, S. S. "The Decline of Traditional Authority: The Case of Ga Mashie State of Accra." In Chieftancy in Ghana: Culture, Governance and Development, edited by Irene K. Odotei and Albert K. Awedoba. Accra: Sub-Saharan Publishers, 2006.

Rakodi, Carole. "Residential Property Markets in African Cities." In The Urban Challenge in Africa: Growth and the Management of Its Large Cities edited by Carole Rakodi. Tokyo, New York, Paris: United Nations University Press, 1997.

Rakodi, Carole, ed. The Urban Challenge in Africa: Growth and the Management of Its Large Cities. Tokyo, New York, Paris: United Nations University Press, 1997.

Reno, W. ñWar, Markets, and the Reconýguration of West Africa's Weak States.ò Comparative Politics 29, no. 4 (1997): 493-510. 
Reno, W. Warlord Politics and African States Boulder, CO: Lynne Rienner Publishers, 1998.

Republic of Ghana. The 1969 Constitution, Tema: Ghana Publishing Corporation, 1969.

Richani, Nazih. Systems of Violence: The Political Economy of War and Peace in Colombia. Albany: State University of New York Press, 2002.

Rothchild, Donald. "Military Regime Performance: An Appraisal of the Ghana Experience." Comparative Politics 12, no. 4 (1980): 459-470.

Sandbrook, R. "Patrons, Clients and Factions: New Dimensions of Conflict Analysis in Africa." Canadian Journal of African Studies 5, no. 1 (1972): 104-118.

Sandbrook, Richard and Jay Oelbaum. ñThe Politics of Economic Decline in Ghana.ò Democracy and Development 2, no. 3 (1999): 19-20.

Saul, Mahir. ñLand Custom in Bare: Agnatic Corporation and Rural Capitalism in Western Burkina.ò In Land in African Agrarian Systems, edited by T.J. Bassett and D.E. Crummey, 75-100. Madison, WI: University of Wisconsin Press, 1993. 
Shipton, P. \& Goheen, M. ñUnderstanding African Land-holding: Power, Wealth and Meaning.ò Africa 62, no. 3 (1992): 307-25.

Shutt, A. K. ñóEveryone Has a Right to Farmô Generational Conflict in the African Freehold Areas of Zimbabwe.ò International Land Tenure Conference, Orlando, Florida, November 1996.

Sklar, Richard L. Nigerian Political Parties: Power in an Emergent African Nation. Princeton: Princeton University Press, 1963.

Sklar, Richard L. "The Nature of Class Domination in Africa." The Journal of Modern African Studies 17, no. 4 (1979): 531-552.

Soludo, Charles C. ñComparative Institutional Development: Lessons from Rural Land Markets in Africa.òDepartment of Economics, University of Nigeria, Nsukka, 2000.

Southgate, C. R. J. and D. Hulme. "Competition, Cooperation and Conflict: The Dynamics of Resource Management in Loitokitok, Kenya." In African Enclosures? The Social Dynamics of Land and Water edited by P. Woodhouse, H. Bernstein \& D. Hulme. London: James Currey, 2000. 
Tipple, A. Graham, D. Korboe, Guy Garrod, and Ken Willis. "Housing Supply in Ghana: A Study of Accra, Kumasi, and Berekum." Progress in Planning 51, no. 4 (1999): 249324.

Toulmin, C. and Julian Quan. Evolving Land Rights, Policy and Tenure in Africa. London: DFID/IIED/NRI, 2000.

Tsikata, D. and W. Seini. ñdentities, Inequalities and Conflicts in Ghana.òCentre for Research on Inequality, Human Security and Ethnicity, Working Paper No. 5. Oxford: University of Oxford, 2004.

UNODC. ñTransnational Organized Crime in the West African Region.òNew York: United Nations, 2005.

USCRI. ñWorld Refugee Survey 2004.ò Washington, D.C.: United States Committee for Refugees and Immigrants, 2004.

Villareal, Andres. "The Social Ecology of Rural Violence: Land Scarcity, the Organization of Agricultural Production, and the Presence of the State." American Journal of Sociology 110, no. 2 (2004): 313-338. 
Wharton, Jr, Clifton R., ed. Subsistence Agriculture and Economic Development. Chicago: Aldine Publishing Co, 1969.

Williams, Donald C. ñReconsidering State and Society in Africa: The Institutional Dimension in Land Reform Policies.ò Comparative Politics 28, no. 2 (1996): 207-224.

Wood, Ellen Meikins. The Origin of Capitalism. New York: Monthly Review Press, 1999.

Woodhouse, P., H. Bernstein and D. Hulme, eds. African Enclosures? The Social Dynamics of Land and Water. London: James Currey, 2000.

World Bank. "Ghana - Policies and Program for Adjustment." Washington, D.C.: The World Bank, 1984.

World Bank. Ghana at a Glance, 2007. Washington, D.C.: 2008.

Ybarra, Megan. "Violent Visions of an Ownership Society: The Land Administration Project in Peten, Guatemala." Land Use Policy 26, no. 1 (2009): 44-54.

Yeboah, Ian E. A. ñStructural Adjustment and Emerging Urban Form in Accra, Ghana.ò Africa Today 47 no. 2 (2000): 61-89. 
Yeebo, Zaya. ñGhana: Defense Committees and the Class Struggle.ò Review of African Political Economy 32 (1985): 64-72.

Zartman, I. William. ñGovernance as Conflict Management in West Africa.òIn Governance as Conflict Management: Politics and Violence in West Africa, edited by I. William Zartman. Washington, D.C.: Brookings Institution Press, 1997.

Zartman, I. William. Governance as Conflict Management: Politics and Violence in West Africa, Washington, D.C.: Brookings Institution Press, 1997. 